UNiVERSIDAde de SÃo Paulo

" Faculdade de Medicina de Ribeirão Preto

\title{
DEPARTAMENTO DE GENÉTICA
}
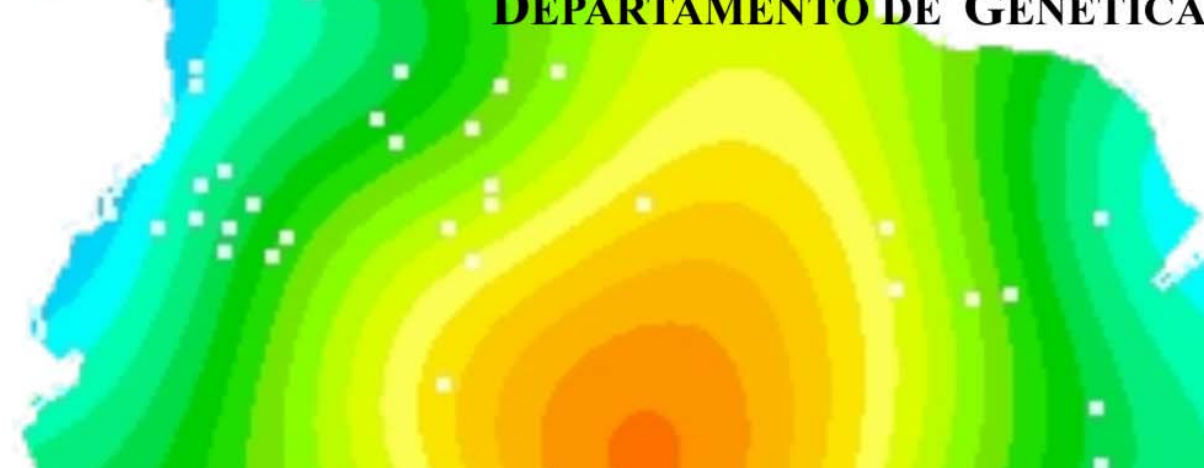

DNA MITOCONDRIAL NA AMAZỐNIA BRASILEIRA:

ESTRUTURA GENÉTICA REGIONAL E INFERÊNCIAS CONTINENTAIS

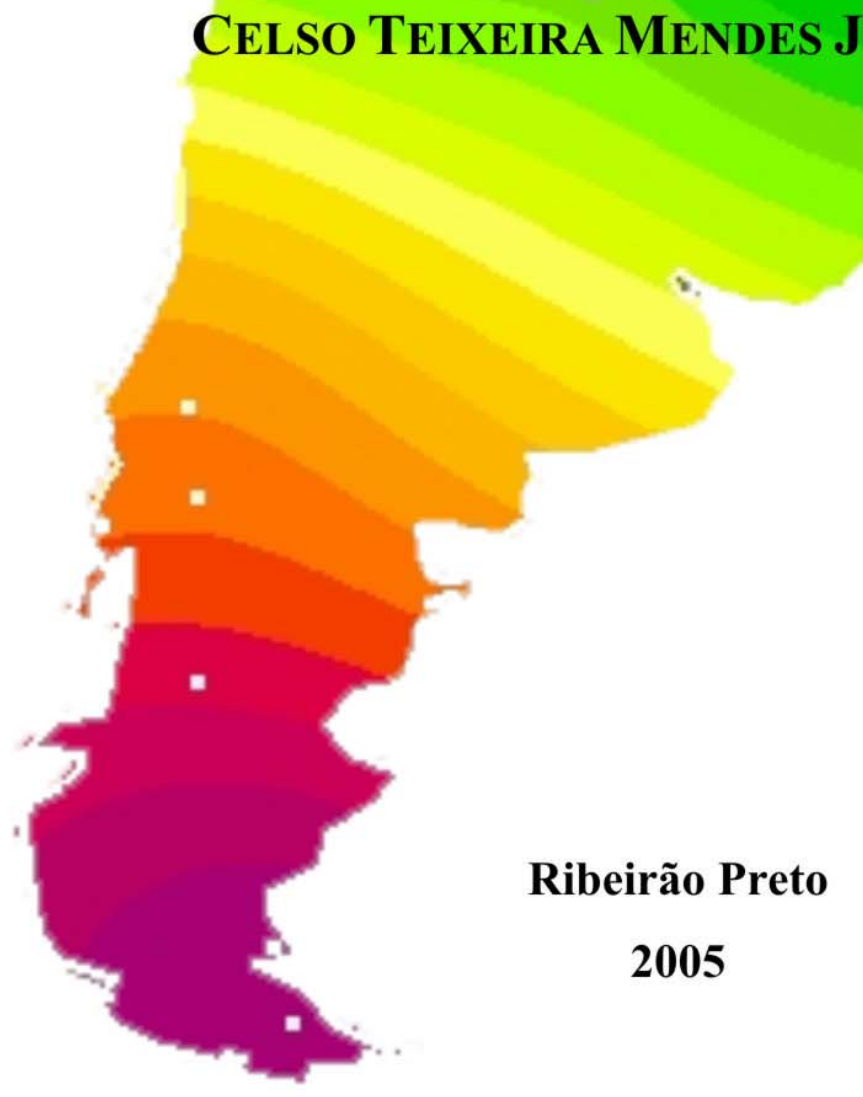


UNIVERSIDADE DE SÃo PAULO

Faculdade de Medicina de Ribeirão Preto

DEPARTAMENTO DE GENÉTICA

CELso TeIXEIRA MENDES JUNIOR

\section{DNA MITOCONDRIAL NA AMAZÔNIA BRASILEIRA:}

ESTRUTURA GENÉTICA REGIONAL E INFERÊNCIAS CONTINENTAIS 
CElso TeiXeIRA MENDES JUNiOR

\title{
DNA MITOCONDRIAL NA AMAZÔNIA BRASILEIRA:
}

\author{
ESTRUTURA GENÉTICA REGIONAL E INFERÊNCIAS CONTINENTAIS
}

Tese apresentada à Faculdade de Medicina de Ribeirão Preto da Universidade de São Paulo, como requisito parcial para obtenção do título de Doutor em Ciências.

Área de concentração: Genética.

Orientador: Prof. Dr. Aguinaldo Luiz Simões

Ribeirão Preto 


\section{FICHA CATALOGRÁFICA}

Mendes-Junior, Celso Teixeira.

DNA mitocondrial na Amazônia brasileira: estrutura genética regional e inferências continentais. Ribeirão Preto, 2005.

184 p. : il12. ; $30 \mathrm{~cm}$

Tese de Doutorado, apresentada à Faculdade de Medicina de Ribeirão Preto/USP - Área de concentração: Genética.

Orientador: Simões, Aguinaldo Luiz.

1. DNA mitocondrial. 2. Índios sul-americanos. 3. Genética Populacional. 


\section{FOLHA DE APROVAÇÃO}

Celso Teixeira Mendes Junior

DNA mitocondrial na Amazônia brasileira:

estrutura genética regional e inferências continentais

Tese apresentada à Faculdade de Medicina de Ribeirão Preto da Universidade de São Paulo, como requisito parcial para obtenção do título de Doutor em Ciências.

Área de concentração: Genética.

Orientador: Prof. Dr. Aguinaldo Luiz Simões

Aprovado em:

Banca Examinadora

Prof. Dr.

Instituição:

Assinatura:

Prof. Dr.

Instituição:

Assinatura:

Prof. Dr.

Instituição:

Assinatura:

Prof. Dr.

Instituição:

Assinatura:

Prof. Dr.

Instituição:

Assinatura: 
Dedico esta tese à minha esposa Karina, aos meus pais Flávia e Celso, às minhas irmãs Andréa e Maria Inêz, aos meus cunhados André e Luigi e aos meus sobrinhos Caio, Pedro e Maria Clara. Obrigado por todo amor, apoio e dedicação. 


\section{AGRADECIMENTOS}

A Deus, por toda força e perseverança a mim concedidas em todos os momentos de fraqueza ao longo desta caminhada.

Ao Prof. Aguinaldo L. Simões. Além da orientação e amizade construída ao longo destes anos, me sinto grato por ter me apresentado a esta área fascinante da Genética e estimulado a conhecer sempre mais.

Aos professores membros da banca examinadora, pela disponibilidade e atenção concedida a este trabalho.

À Profa. Eucléia P. B. Contel, pessoa que tenho enorme carinho, respeito e admiração.

A todos os professores do Departamento de Genética, pelo acolhimento e conhecimento compartilhado, em especial às professoras Catarina S. Takahashi, Elza T. S. Hojo, Márcia G. Bitondi, Maura H. Manfrin e Zilá L. P. Simões, que me acompanham desde a graduação e que me introduziram à área de genética e evolução.

Ao amigo Luzitano Brandão Ferreira, pela revisão do texto e por todo auxílio prestado nestes últimos anos. Obrigado mesmo.

À minha esposa Karina, não só pelo auxílio na revisão do texto, mas pelo amor e compreensão neste momento tão importante.

Às amigas Ana Lúcia Pimentel, Cláudia E. Vieira Wiezel e Maria do Carmo T. Canas, por todo auxílio laboratorial prestado.

A todos os amigos do Laboratório de Genética Bioquímica, entre eles Adriana, Ana Lilian, Ana Paula, Bete, Débora, Eddy, Edna, Eliana, Izabel, Jeanne, Joelington, Juliana, Jussara, Daniel, Lenicy, Lenize, Marcelo, Mariana, Mônica, Regina, Renata Camacho, Renata Simões, Ricardo, Rosana, Rubiane, Sandra e Yara, por construírem ambiente de trabalho simultaneamente harmonioso e estimulante.

Aos amigos do Departamento de Genética, em especial ao pessoal do Bloco A: Adriana, Anete, Bione, Evandro, Fernando, Karina, Makert, Roberto e Thiago.

Aos funcionários do Departamento de Genética, em especial às secretárias Cleusa, Maria Aparecida e Susie, que estão sempre dispostas a ajudar.

À Coordenação de Aperfeiçoamento de Pessoal de Nível Superior (CAPES) pela bolsa concedida para o desenvolvimento desta tese.

Aos povos indígenas que contribuíram doando amostras de precisas de seu sangue. 
"[...] it is time to recognize that recombination (not to mention selection) might be a feature of human mtDNA evolution and to begin to incorporate this issue in our evolutionary reconstructions. It might well be that most conclusions derived from the twin assumptions of clonal inheritance and zero recombination are qualitatively correct, but our dogmatic acceptance of these assumptions now seems inappropriate. We should consider the idea that our mitochondrial common ancestor might not simply be 'Eve', or even 'Steve', but a combination of the two. 'St. Eve' perhaps?"

Jon Slate e Neil J. Gemmell (2004) 


\section{RESUMO}

\section{MENDES-JUNIOR, C. T. DNA mitocondrial na Amazônia brasileira: estrutura genética}

regional e inferências continentais. 2005. $184 \mathrm{f}$. Tese de Doutorado - Faculdade de Medicina de Ribeirão Preto, Universidade de São Paulo, Ribeirão Preto.

Sítios arqueológicos, polimorfismos genéticos clássicos e marcadores moleculares (estes em menor quantidade) foram empregados nos últimos anos para o desenvolvimento de modelos de povoamento e investigação de rotas migratórias percorridas pelos primeiros habitantes do continente sul-americano. Apesar destes esforços, muitas incertezas relacionadas aos movimentos populacionais realizados pelos ancestrais dos índios contemporâneos na América do Sul ainda permanecem. Com o objetivo de estudar a estrutura populacional dos indígenas da Amazônia e contribuir para o melhor entendimento do povoamento deste continente, polimorfismos que definem os haplogrupos fundadores do DNA mitocondrial nativoamericano foram analisados em 308 indígenas pertencentes a 16 aldeias de 7 tribos da região central da Amazônia. A posição central ocupada por estas tribos no continente sul-americano faz com que sejam relevantes nas tentativas de reconstrução dos movimentos populacionais sul-americanos. Nesta região, existe particular interesse pela estrutura genética da tribo Tikúna, inicialmente tida como enigmática por se preservar como uma das únicas grandes tribos pouco miscigenadas da Amazônia central, e do grupo lingüístico Pano, que embora se distribua por grande extensão territorial, apresenta homogeneidades étnica, lingüística e cultural notáveis, razão pela qual as populações (tribos) deste grupo são consideradas como parte de uma mesma tribo. Oito aldeias Tikúna e seis aldeias de quatro tribos Pano (Katukina, Kaxináwa, Marúbo e Yaminawa) fazem parte deste estudo. Os resultados indicam que constituem populações realmente pouco miscigenadas, sendo a mistura inter-étnica feminina praticamente desprezível $(0,32 \%)$. Foi encontrada heterogeneidade entre aldeias Tikúna, 
sendo observados dois grupos altamente homogêneos que diferem consideravelmente entre si. Em relação aos Pano, a homogeneidade lingüística e cultural deste grupo não se reflete em sua estrutura genética, visto que os níveis de heterogeneidade entre populações Pano são equivalentes ou até mesmo superiores aos observados entre populações de afiliação lingüística distintas. No geral, as mulheres indígenas da região central da Amazônia se apresentaram mais heterogêneas do que os homens, o que pode ser interpretado como maiores taxas migratórias femininas. Por meio de análises continentais foi observado que tanto a afiliação lingüística quanto a geografia exercem forte influência no padrão de variabilidade genética nas Américas. Quando apenas populações ameríndias são consideradas, a heterogeneidade é maior entre populações sul-americanas do que norte-americanas, o que estaria relacionado com maior atuação da deriva genética neste continente. Os dados corroboram a hipótese de que uma onda migratória principal seria responsável pelo povoamento das Américas. Ao longo deste movimento migratório, múltiplos efeitos do fundador teriam ocorrido até alcançar a América do Sul. Ao entrar na América do Sul, tal onda teria assumido rotas distintas direcionadas ao norte (acompanhando a costa Atlântica em direção ao leste do continente), ao sul (acompanhando a costa do Oceano Pacífico) e, possivelmente, em direção ao centro da Amazônia. Visto que as principais rotas migratórias foram necessariamente percorridas por membros de ambos os sexos, a análise de marcadores patrilineares seria pertinente para se testar esta rota em direção ao centro da Amazônia, bem como as duas rotas clássicas anteriormente propostas e aqui corroboradas.

Palavras-chave: DNA mitocondrial. Índios sul-americanos. Genética populacional. 


\begin{abstract}
MENDES-JUNIOR, C. T. Mitochondrial DNA in the Brazilian Amazon: regional genetic structure and continental inferences. 2005. $184 \mathrm{f}$. Tese de Doutorado - Faculdade de Medicina de Ribeirão Preto, Universidade de São Paulo, Ribeirão Preto.
\end{abstract}

Archeological sites, classical polymorphisms and molecular markers (in smaller amount) were employed during the last years to develop models regarding peopling and to investigate the routes followed by the first inhabitants of South America. In spite of these efforts, a great amount of uncertainties related to the populational movements performed by the ancestors of current Amerindians from South America still remains. Aiming to study the population structure of the indigenous people from Amazon and to contribute to a better understanding regarding South America peopling, polymorphisms defining the mitochondrial DNA founder haplogroups of Native-Americans were studied in 308 Amerindians pertaining to 16 villages of seven tribes from the central part of Amazon. The central position occupied by these tribes in South-American geography renders them special interest for attempts to reconstruct the populational movements in this continent. In this central region, there is particular interest in the genetic structure of the Tikúna tribe, initially considered as an enigmatic tribe due to their preservation as one of the very few large and relatively pure tribes of Central Amazon. There is also interest in the Pano (linguistic) group that, in spite of being distributed through a really large area, still presents notable ethnic, linguistic and cultural homogeneities, which is the reason why the various populations (tribes) are considered as samples of a single tribe. Eight Tikúna villages along with six villages from four Pano tribes (Katukina, Kaxináwa, Marúbo e Yaminawa) are part of this research. The results obtained indicate that the populations analyzed are actually weakly admixed, with an almost negligible female inter-ethnic admixture $(0.32 \%)$. Heterogeneity was found among the Tikúna villages, identified in the 
form of two highly homogeneous groups that are remarkably different from each other. Regarding the Pano, the linguistic and cultural homogeneity is not reflected in this group's genetic structure, as can be seen by the high levels of heterogeneity found between the Pano populations, equal to or greater than the observed between other populations belonging to different languages. Overall, indigenous women from central Amazon are more structured than man, which can be interpreted as a higher female migration rate. Continental analysis revealed that both language and geography exert strong influence over the genetic diversity pattern found in America. When only Amerindian populations are considered, it can be observed a higher level of heterogeneity in South America than in North America, which could be related to an increase in genetic drift in the former. Presented data corroborate the hypothesis of one major migration being responsible for America peopling. Multiple founder effects could have occurred along with this migratory movement until reaching South America. Following the entrance in this continent, such wave could have been split into different routes pointing to the north of part of South America (following the Atlantic Coast to the eastern part of the continent), to the south (along with the Pacific Coast) and possibly to the central part of Amazon. As long as the major migratory routes were essentially followed by members of both genders, the analysis of patrilinear markers would be pertinent to confirm or not such route pointing to the Central Amazon, as well as the two classical routes here corroborated.

Key-words: DNA, mitochondrial. Indians, South-American. Genetics, population. 


\section{SUMÁRIO}

1.1 O POVOAMENTO DA AMÉRICA DO SUL

1.2 ONDAS MIGRATÓRIAS INFERIDAS A PARTIR DE MARCADORES GENÉTICOS

1.2.1 DNA MITOCONDRIAL

1.2.2 CROMOSSOMOS Y

1.3 ROTAS MIGRATÓRIAS NA AMÉRICA DO SUL

5.1 AMOSTRAS POPULACIONAIS INDÍGENAS

5.2 ASPECTOS ÉTICOS

5.3 COLETA DE AMOSTRAS

5.4 EXTRAÇÃO DE DNA

5.5 POLIMORFISMOS DO DNA MITOCONDRIAL

5.5.1 PANORAMA GERAL SOBRE O MTDNA

5.5.2 MARCADORES POLIMÓRFICOS ESTUDADOS

5.6 REAÇão EM CAdeia da POlimerase (PCR)

5.7 REAÇÃO DE RESTRIÇÃO

5.8 ELETROFORESE EM GEL DE POLIACRILAMIDA

5.9 COLORAÇÃO E ESTOCAGEM DO GEL

5.10 ANÁLISES ESTATÍSTICAS

5.10.1 FREQÜÊNCIAS ALÉLICAS

5.10.2 DIVERSIDADE GENÉTICA INTRA-POPULACIONAL 50

5.10.3 DIVERSIDADE GENÉTICA INTER-POPULACIONAL: $F_{S T}$

5.10.4 DIVERSIDADE GENÉTICA INTER-POPULACIONAL: $F_{S T}$ POPULAÇÃO-ESPECÍFICO

5.10.5 TESTE EXATO DE DIFERENCIAÇÃO POPULACIONAL

5.10.6 ANÁLISE DE VARIÂNCIA MOLECULAR (AMOVA) 53

5.10.7 DISTOGRAMAS

5.10 .8 ÍNDICE DE AUTOCORRELAÇÃO ESPACIAL PARA ANÁLISE DE DNA 56

5.10.9 DISTÂNCIAS GENÉTICAS E REPRESENTAÇÕES GRÁFICAS

5.10.10 MAPA GEOGRÁFICO DE FREQÜÊNCIAS ALÉLICAS

5.10.11 OUTRAS ANÁLISES $\quad 62$ 
6.1 DIVERSIDADE INTRA-POPULACIONAL

6.2 DIVERSIDADE INTER-POPULACIONAL

6.3 REPRESENTAÇÃO GRÁFICA DAS DISTÂNCIAS GENÉTICAS

6.4 ANÁLISE DE VARIÂNCIA MOLECULAR

6.5 AIDA

6.6 DIVERSIDADE INTER-POPULACIONAL: MTDNA E CROMOSSOMO Y

6.7 META-ANÁLISE EM ESCALA CONTINENTAL

\begin{tabular}{ll}
7 DISCUSSÃO & 97 \\
\hline
\end{tabular}

$\begin{array}{ll}7.1 \\ \text { MISTURA INTER-ÉTNICA } & 97\end{array}$

7.2 DIVERSIDADE INTRA-POPULACIONAL

7.3 DIVERSIDADE INTRA-TRIBAL E ISOLAMENTO DOS TIKÚNA 101

7.4 DIVERSIDADE INTRA-TRIBAL DOS PANO $\quad 104$

7.5 VARIABILIDADE GENÉTICA NO CENTRO-OESTE DA AMAZÔNIA BRASILEIRA 107

7.6 PADRÕES DE FLUXO GÊNICO SEXO-ESPECÍFICOS

7.7 META-ANÁLISE EM ESCALA CONTINENTAL

7.7.1 AMOVA: ASPECTOS LINGÜÍSTICOS E GEOGRÁFICOS 113

7.7.2 PADRÃO GEOGRÁFICO DA VARIABILIDADE DO MTDNA NAS AMÉRICAS 119

8 CONCLUSÕES 129

REFERÊNCIAS BIBLIOGRÁFICAS

APÊNDICE A $\quad$ ERRO! INDICADOR NÃO DEFINIDO.

\begin{tabular}{ll} 
APÊNDICE B & 161 \\
\hline
\end{tabular} 


\section{Introdução}

A migração do homem moderno para as Américas representou um dos últimos grandes eventos de povoamento, sendo mais antigo apenas do que o povoamento das ilhas do Leste do Oceano Pacífico. Embora seja um evento relativamente recente na história evolutiva humana e que vem sendo extensivamente estudado, muitas das questões inicialmente formuladas permanecem ainda sem respostas definitivas (Salzano 2002; Schurr 2004; Schurr e Sherry 2004): dados genéticos, lingüísticos, arqueológicos e geológicos levam à discordância com relação (a) ao momento em que se iniciou a entrada do homem moderno no continente americano (pode ter ocorrido entre 12 e 40 mil anos atrás), (b) ao número de ondas migratórias principais e secundárias que entraram nas Américas e (c) à origem geográfica dos primeiros colonizadores deste continente.

Uma das poucas questões cuja resposta aparentemente é consenso entre os membros da comunidade científica é o local de entrada dos primeiros habitantes das Américas. Registros geológicos e paleo-climáticos indicam que durante o último evento de glaciação, entre 10.000 e 24.000 anos atrás, o rebaixamento do nível do mar em conseqüência da formação de grandes geleiras levou à formação de um estreito de terra na região da Beríngia, por onde foi possível a travessia terrestre entre o Nordeste da Ásia e o Noroeste das Américas (Fiedel 2000; Fix 2002; Schurr 2004). Embora a travessia terrestre seja relativamente mais simples, a travessia marítima utilizando-se pequenas embarcações não seria muito desafiadora, uma vez que barreiras aquáticas equivalentes ou maiores que os 90 quilômetros correspondentes ao estreito de Bering atual, foram sobrepujadas durante o povoamento da Austrália e do Japão, que teriam ocorrido cerca de 40.000 e 17.000 anos atrás, respectivamente (Fiedel 2000). 
Após a entrada no continente, a passagem dos primeiros colonizadores da Beríngia em direção ao interior da América do Norte encontrava-se obstruída por imensas geleiras com até 1.600 metros de altura - Cordilerana, na porção oeste, e Laurentidea, na porção leste (Fiedel 2000). Este fato faz com que a movimentação em direção ao sul dos primeiros desbravadores deste continente seja mais plausível por meio de rotas costeiras, adentrando posteriormente em direção ao interior do continente através de rios que deságuam no Oceano Pacífico (Fladmark 1979; Gruhn 1988; Fix 2002). Entretanto, não se pode descartar uma possível travessia interiorana através do corredor de Alberta, passagem de 1.200 quilômetros de extensão que teria se aberto entre as duas geleiras supracitadas, devido ao aquecimento abrupto no hemisfério norte entre 11.500 e 12.300 anos atrás, permitindo acesso direto entre a Beríngia e o interior da América do Norte (Fiedel 2000).

A dispersão por toda a América do Norte até a chegada à América Central foi rápida. De acordo com modelo teórico que assume rápido crescimento populacional (de 1,4\% a 3,4\% ao ano) a partir da região de saída do Corredor de Alberta (Martin 1973), toda a região sub-glacial da América do Norte pode ter sido completamente povoada entre 340 e 800 anos após a transposição das enormes geleiras por bandos de caçadores formados por não mais do que cem indivíduos. Esta rápida expansão teria levado à extinção de grandes herbívoros, o que por sua vez estimulou avanço em direção ao sul, a uma taxa de 16 quilômetros por ano.

\subsection{0 povoamento da América do Sul}

Os ameríndios sul-americanos teriam se originado a partir de migrações de caçadores-coletores que alcançaram a América do Sul, através do Istmo do Panamá, que consiste em uma constrição da América Central, conectando esta última à porta de entrada 
(Colômbia) do território sul-americano (Keyeux et al. 2002). Por se tratar de uma região de difícil passagem até mesmo durante a época mais seca, devido à presença da Selva de Darien, na divisa entre Panamá e Colômbia, e ao Rio Atrato, na Colômbia, uma rota migratória alternativa desde a Flórida até o Norte da América do Sul, através das ilhas Caribenhas, foi sugerida (Cruxent 1968; Salzano e Callegari-Jacques 1988). Até mesmo eventual chegada de polinésios à costa peruana pode ter ocorrido, mas apenas em época muito mais recente, devido ao próprio povoamento tardio de tal região (Salzano e Callegari-Jacques 1988; Cann e Lum 1996; Lum e Cann 2000). Embora pouco se saiba sobre a continuação deste processo, os indígenas posteriormente se dispersaram, se estabeleceram por todo o território sul-americano e desenvolveram culturas distintas, utilizando os recursos naturais existentes. Assumindo-se a taxa de expansão terrestre de 16 quilômetros por ano e de crescimento populacional de 3,4\% ao ano, os primeiros indígenas teriam alcançado o limite meridional do continente sul-americano menos de mil anos após a travessia do Corredor de Alberta e início da expansão na América do Norte (Fix 2002). Admitindo-se o modelo de povoamento ao longo da costa do Pacífico, por meio de pequenas embarcações, a chegada a Terra do Fogo teria ocorrido até mesmo mais rapidamente, uma vez que não haveria necessidade de que todo o interior do continente já estivesse povoado.

\subsection{Ondas migratórias inferidas a partir de marcadores genéticos}

O processo de povoamento das Américas não apenas preencheu demograficamente os continentes, mas também estabeleceu o padrão de variabilidade genética entre as populações. Não se sabe exatamente como era tal padrão, uma vez que a variabilidade genética contemporânea foi moldada por processos de fissão e fusão de populações, migrações e fluxo gênico entre populações geograficamente estabelecidas e redução populacional após a 
chegada dos colonizadores europeus às Américas. A redução populacional, entretanto, não resultou em perda extrema de variabilidade genética, visto que muitas variantes genéticas estão difundidas por ambos os continentes (O'Rourke et al. 1992; Crawford 1998; Fix 2002). A menor variabilidade genética encontrada dentro de populações indígenas em relação a populações de outros continentes decorre predominantemente do processo de redução de tamanho efetivo populacional e de variabilidade genética (efeito gargalo) ao qual teriam sido expostos os primeiros Asiáticos a virem para as Américas (Torroni et al. 1992; Wallace e Torroni 1992).

É justamente nos dados provenientes de populações nativo-americanas contemporâneas que a maior parte dos estudos de variabilidade genética vêm se baseando para o desenvolvimento de hipóteses e modelos biológicos para o povoamento e expansão populacional nas Américas.

O primeiro, elaborado com base em polimorfismos genéticos clássicos, juntamente com dados relativos à classificação lingüística e morfologia dental (Greenberg et al. 1986), sugere três ondas migratórias distintas que teriam ocorrido através do Estreito de Bering. Cada uma delas correspondendo a um dos três grupos lingüísticos principais: a primeira delas teria ocorrido a cerca de 12.000 anos atrás e dado origem aos Ameríndios norte-americanos e sul-americanos, enquanto que a segunda e terceira teriam originado os Na-Dene e Esquimós-Aleutas (Greenberg et al. 1986; Greenberg 1987). Embora muitos antropólogos apontem para a entrada anterior dos Na-Dene em relação aos Esquimós-Aleutas, os proponentes deste modelo não entraram em consenso sobre a ordem e profundidade temporal das duas últimas ondas migratórias (Szathmary 1993b). A análise de conjunto mais completo de dados, tanto quanto ao número de marcadores clássicos quanto ao número de populações, levou à estimativa de divergência entre Ameríndios e Mongolóides em torno de 31.000 anos 
atrás (Cavalli-Sforza et al. 1994). A separação entre Na-Dene e Esquimós teria ocorrido provavelmente na Ásia há cerca de 18.000 anos atrás (Cavalli-Sforza et al. 1994).

Embora trabalhos com diferentes marcadores de DNA tenham se voltado para resolução de questões relacionadas ao povoamento das Américas, os achados mais significativos são decorrentes da análise de haplogrupos e haplótipos do DNA mitocondrial e do cromossomo Y, marcadores estes livres de recombinação cromossômica e com padrões de herança exclusivamente materno e paterno, respectivamente.

\subsubsection{DNA mitocondrial}

Logo após o início dos estudos com DNA mitocondrial (mtDNA), percebeu-se que os nativos americanos foram fundados por um número limitado de linhagens maternas que deixaram a Ásia e que, após o início do processo de tribalização nas Américas, polimorfismos raros foram se tornando prevalentes e novas mutações foram se acumulando em tais linhagens (Wallace et al. 1985; Schurr et al. 1990). Apenas em 1990 foi visto que se tratava de quatro haplogrupos principais (Schurr et al. 1990), posteriormente denominados A, B, C, e D (Torroni et al. 1992). Estes haplogrupos, juntamente com um quinto haplogrupo X (Forster et al. 1996; Brown et al. 1998; Smith et al. 1999; Malhi e Smith 2002; Reidla et al. 2003), já se encontravam presentes nas Américas antes da chegada dos colonizadores europeus, como pôde ser evidenciado pela análise de DNA de restos de esqueletos e múmias datados de épocas pré-colombianas (Stone e Stoneking 1993; Hauswirth et al. 1994; Lalueza-Fox 1996; Monsalve et al. 1996; Parr et al. 1996; Ribeiro-dos-Santos et al. 1996; Lalueza-Fox et al. 1997; Stone e Stoneking 1998; Stone e Stoneking 1999; O'Rourke et al. 2000; Lalueza-Fox et al. 2001; Malhi e Smith 2002; Lalueza-Fox et al. 2003). O haplogrupo X, entretanto, se 
encontra aparentemente ausente em populações indígenas contemporâneas das Américas Central e do Sul (Dornelles et al. 2004).

As primeiras hipóteses migratórias baseadas nos dados de diversidade de seqüência de cada um dos quatro haplogrupos de mtDNA em populações Ameríndias e Na-Dene indicavam que estes dois grupos teriam sido fundados por pelo menos duas ondas migratórias distintas. A primeira teria trazido os haplogrupos $\mathrm{A}, \mathrm{C}$ e $\mathrm{D}$ (todos com elevada diversidade de seqüência) entre 21.000 e 42.000 anos atrás, enquanto que a última (entre 5.250 e 16.000 anos atrás) teria trazido o haplogrupo A (com menor diversidade de seqüência) encontrado nos Na-Dene. Uma onda migratória intermediária, que teria se misturado com os Ameríndios pré-existentes e posteriormente com algumas populações Na-Dene, seria uma possível explicação para os níveis de diversidade encontrados nos haplogrupos B compartilhados por estes dois grupos (Torroni et al. 1992; Torroni et al. 1993). Estes dados levaram à hipótese de quatro migrações (Wallace 1995). Duas delas teriam dado origem aos Ameríndios, sendo que os haplogrupos A, C e D teriam sido trazidos durante a primeira delas (entre 26.000 e 34.000 anos atrás) a partir da Ásia Central, enquanto que o haplogrupo B apenas na segunda (entre 12.000 e 15.000 anos atrás) a partir da costa da Sibéria. A terceira e a quarta onda migratória teriam originado os Na-Dene (entre 7.200 e 9.000 anos atrás) e Esquimós-Aleutas (sem datação devido ao pequeno tamanho amostral), respectivamente (Wallace 1995). Desta forma, a onda migratória anteriormente proposta que teria dado origem aos Ameríndios (Greenberg et al. 1986) é aqui convertida em duas ondas independentes que teriam origens e profundidades temporais distintas.

Outra hipótese, baseada apenas no estudo de populações do grupo lingüístico Ameríndio, afirma que quatro ondas migratórias, cada uma associada a um dos quatro principais haplogrupos fundadores, originárias de quatro regiões geográficas distintas da Ásia, 
teria ocorrido entre 14.000 e 21.000 anos atrás, o que é consistente com os dados paleo-geográficos (Horai et al. 1993).

Em 1995, baseando-se apenas nos dados de freqüências dos quatro haplogrupos principais e distâncias genéticas entre populações nativo-americanas, Merriwether, Rothhammer e Ferrell (1995) concluíram que uma única onda migratória e/ou origem geográfica teria sido responsável pelo povoamento das Américas. Esta onda migratória teria ocorrido em momento muito mais recente do que anteriormente proposto (Torroni et al. 1992; Wallace 1995), uma vez que, ao contrário do que se imaginava, mais de uma variante de cada haplogrupo entraram nas Américas (Bailliet et al. 1994; Merriwether e Ferrell 1996), o que faz com que o tempo de divergência das linhagens de um determinado haplogrupo não seja equivalente ao momento de entrada nas Américas, pois boa parte do processo de divergência de linhagens já havia se iniciado na Ásia (Merriwether et al. 1995). Menor número de haplótipos do haplogrupo B do que dos demais teria sido trazido nesta leva migratória, o que justificaria a menor diversidade de seqüência previamente relatada. Além disso, o menor tamanho amostral das poucas populações Na-Dene estudadas seria responsável pela menor diversidade de seqüências neste grupo lingüístico (Merriwether et al. 1995). Uma população da Mongólia (ou populações ancestrais aos mongóis contemporâneos) seria uma potencial fonte de tal onda migratória (Merriwether et al. 1996), já que apresenta os quatro haplogrupos fundadores principais propostos pelo grupo de Antonio Torroni e Douglas C. Wallace, bem como sete dos nove haplogrupos fundadores propostos por outros pesquisadores (Bailliet et al. 1994; Merriwether e Ferrell 1996).

Analisando-se seqüências nucleotídicas da primeira região hipervariável do DNA mitocondrial disponíveis na literatura, novamente uma única onda migratória foi proposta entre 20.000 e 25.000 (Forster et al. 1996) ou entre 30.000 e 43.000 anos atrás (com intervalo de confiança de 95\% estendendo para 22.000 e 55.000 anos atrás) (Bonatto e Salzano 1997b). 
A divergência entre os Ameríndios e os grupos que permaneceram na Beríngia teria se iniciado ali mesmo devido ao bloqueio do corredor de Alberta (entre 14.000 e 20.000 anos atrás), isolando assim os dois grupos por milhares de anos (Bonatto e Salzano 1997b). Todavia, com o final da glaciação, uma re-expansão demográfica e geográfica a partir de populações que permaneceram estabelecidas na Beríngia ou Noroeste da América do Norte teria ocorrido a cerca de 11.000 anos atrás, da qual se diferenciaram os Chukchi siberianos, Na-Dene e Esquimós contemporâneos, como pôde ser visto pela análise de diversidade do haplogrupo A2 (Forster et al. 1996). Dados de diversidade fundamentados nas duas seqüências hipervariáveis de todos os quatro haplogrupos corroboram esta hipótese, indicando ainda que o grupo de colonizadores formados por cerca de 2 mil mulheres numa população de menos de 5 mil fundadores (Bonatto e Salzano 1997a). Um rápido avanço em direção ao sul teria levado a um evento fundador na América do Sul por volta de 18.000 anos atrás (Forster et al. 1996). Estes achados estariam de acordo com modelo anteriormente proposto (Szathmary 1993a).

Embora não tenha havido a inclusão de populações Na-Dene e Esquimó-Aleutas, a análise de $8,8 \mathrm{~kb}$ localizados fora da região controladora do DNA mitocondrial em 30 Ameríndios sul-americanos deu suporte à hipótese de uma única onda migratória por volta de 21.000 anos atrás, com o intervalo de confiança de 95\% indicando que a onda deve ter ocorrido entre 18.600 e 23.400 anos atrás (Silva et al. 2002).

\subsubsection{Cromossomos $Y$}

Praticamente uma década após os primeiros estudos com DNA mitocondrial é que se iniciaram os estudos de cromossomo Y, ficando evidente a existência de um haplótipo fundador principal nas Américas (Pena et al. 1995; Santos et al. 1996; Bianchi et al. 1997). 
Com a descoberta da transição DYS199 $\mathrm{C} \rightarrow \mathrm{T}$ (característica do haplogrupo Q-M3) (Underhill et al. 1996) encontrada em forte desequilíbrio de ligação com o alelo de 186pb do microssatélite DYS19, e que teria ocorrido a cerca de 30.000 anos atrás após os ancestrais nativo-americanos deixarem a Mongólia e o sudeste da Sibéria, foi proposta uma origem única para os nativo-americanos, com subseqüente diferenciação haplotípica já nas populações indígenas (Underhill et al. 1996; Lell et al. 1997). Um conjunto mais amplo de marcadores deu suporte à hipótese de uma única onda migratória, desta vez partindo da Sibéria Central e salientando a diferenciação populacional na Beríngia (Santos et al. 1999). Estes achados corroboram hipótese formulada com base no mtDNA (Forster et al. 1996; Bonatto e Salzano 1997b).

Com a análise de vários microssatélites ligados ao cromossomo $\mathrm{Y}$, diversos haplótipos derivados do haplogrupo fundador foram identificados (Bianchi et al. 1998), inclusive um haplótipo fundador secundário (haplogrupo P-M45) no qual teria ocorrido a transição DYS199 C $\rightarrow$ T entre 9.000 e 11.000 anos atrás (Ruiz Linares 1999). A descoberta de um terceiro haplogrupo definido pela transição RPS4Y $\mathrm{C} \rightarrow \mathrm{T}$ em Ameríndios norte-americanos e Na-Denes, e o fato de haplótipos DYS199-T e RPS4Y-T não serem encontrados em uma mesma região asiática, levantou a hipótese de que duas ondas migratórias masculinas distintas teriam chegado às Américas (Karafet et al. 1999). Novos dados indicaram que a primeira onda teria partido da região sul da Sibéria Central, atravessado a Chukotka (aonde teria surgido o haplogrupo Q-M3 a partir do haplogrupo P-M45) e chegado até a América do Sul, enquanto que a segunda teria partido da Sibéria Oriental (trazendo a mutação RPS4Y-T e outra variante do haplogrupo P-M45) e alcançado apenas as Américas do Norte e Central (Lell et al. 2002). Entretanto, novos dados indicaram que tais haplogrupos teriam se originado nas Montanhas Altai, no sudoeste da Sibéria, o que voltou a dar suporte à hipótese de uma única migração, que teria ocorrido a não mais de 17.200 anos atrás (Zegura et al. 2004). 
A identificação da mutação M-242 (Seielstad et al. 2003), uma transição $C \rightarrow T$ que teria entrado nas Américas pouco depois de seu surgimento, entre cerca de 15.000 e 18.000 anos atrás, permitiu datar de maneira mais confiável o início do processo de povoamento das Américas (Bortolini et al. 2003; Seielstad et al. 2003; Schurr 2004). Segundo Bortolini et al. (2003), o povoamento das Américas teria se iniciado há cerca de 14.000 anos, o que é consistente com evidências arqueológicas; duas ondas migratórias masculinas principais teriam partido do sul da Sibéria Central para as Américas (a segunda delas restrita à América do Norte), o que corrobora a hipótese recentemente formulada com base em marcadores do cromossomo Y (Lell et al. 2002).

\subsection{Rotas migratórias na América do Sul}

Muito embora tenha sido analisada geneticamente uma maior quantidade de populações sulamericanas do que norte-americanas (Salzano 2002), a maior parte dos esforços estão voltados para o esclarecimento das questões referentes à chegada do homem à América, sendo que pouca atenção tem sido dispensada para os eventos de povoamento da América do Sul (Tarazona-Santos et al. 2001a).

Vários sítios arqueológicos foram descobertos na América do Sul, muitos deles com datações que remetem aos momentos iniciais do povoamento deste continente (Salzano e Callegari-Jacques 1988; Fiedel 2000). Por volta de 12.000 anos atrás, os humanos estavam distribuídos por quase toda a América do Sul (Salzano e Callegari-Jacques 1988; Dillehay 2000). Juntamente com outras fontes de informações, a presença de sítios arqueológicos distribuídos por toda a América do Sul, com exceção da Bacia Amazônica (quer seja por problemas de preservação dos remanescentes arqueológicos, quer seja pelo 
não-estabelecimento inicial de populações indígenas naquela região devido a fatores ambientais), formam uma base, embora com alto grau de incerteza, para inferências preliminares sobre eventuais rotas migratórias percorridas pelos primeiros habitantes do continente (Schmitz 1983; Salzano e Callegari-Jacques 1988). Dentre elas, destacam-se uma rota clássica ao longo da costa do Pacífico e da Cordilheira dos Andes, em direção ao extremo sul do continente, e outra ao Norte, ao longo da Venezuela e Guianas, em direção ao Leste do continente até o norte da Amazônia. Rotas migratórias secundárias foram propostas, tais como: (a) movimento a partir da área da costa do Pacífico, entre as Bacias do Rio Amazonas e do Rio da Prata, sentido leste, (b) migrações norte-sul de habitantes da costa Atlântica e (c) fluxo ao longo da região Pampa-Patagônia (Schmitz 1983; Salzano e Callegari-Jacques 1988).

Grupos sangüíneos, antígenos de histocompatibilidade, proteínas séricas e eritrocitárias examinadas por eletroforese foram os primeiros marcadores genéticos polimórficos que tiveram suas freqüências extensamente mapeadas em populações indígenas sul-americanas (Salzano e Callegari-Jacques 1988; Cavalli-Sforza et al. 1994). As relações entre as aldeias de mesma tribo, tribos distintas e grupos lingüísticos foram intensamente abordadas. Pela análise de um conjunto de sete marcadores clássicos (MNSs, P, Rh, Duffy, Kidd, Diego e Haptoglobina) estudados em 58 grupos indígenas distribuídos por toda a América do Sul, Salzano e Callegari-Jacques (1988) procuraram verificar se os padrões genéticos confirmariam as indicações migratórias obtidas pela análise dos sítios arqueológicos. Pela análise de componentes principais, foi visto que os três primeiros componentes explicavam 53\% da variância total observada.

Impulsionados pela hipótese de que o padrão geográfico nos valores de cada um destes componentes poderia indicar rotas migratórias seguidas pelos ancestrais dos indígenas atuais, os valores transformados de cada um dos três componentes relativos às 58 localidades amostradas foram transferidos para três mapas independentes da América do Sul (Salzano e 
Callegari-Jacques 1988). O principal componente revelou gradiente aumentando (a) do noroeste do continente em direção ao sul (norte do Chile e Chacos), compatível com uma rota ao longo do Pacífico e (b) a partir da Colômbia em direção às Guianas e ao Amapá (leste), experimentando leve declínio no centro/leste do Brasil, compatível com uma rota ao longo do norte da região amazônica. A região dos Chacos se apresentou como núcleo de convergência ou dispersão, indicando um processo de micro-diferenciação nesta região. O segundo componente exibiu gradiente crescente a partir da região do mar do Caribe em direção ao centro do continente, atingindo valores máximos no norte do Chile (Atacama), o que foi interpretado como evidência da região do Caribe como pólo secundário de dispersão, apoiando achados anteriores (Cruxent 1968). O terceiro componente principal revelou elevados valores no Peru, no Delta do Rio Orinoco e na Guiana Francesa, os quais foram se reduzindo em direção ao centro do continente, corroborando rotas migratórias a partir de outros centros de origem menor importância: mar do Caribe e Oceano Pacífico (Salzano e Callegari-Jacques 1988). Os principais achados estão de acordo com as principais inferências obtidas pela análise dos sítios arqueológicos. No entanto, os marcadores clássicos constituem ferramentas genéticas pouco informativas, se comparados às atuais, além de estarem sob maior influência da Seleção Natural. O gradiente Norte-Sul, por exemplo, poderia ser decorrente de efeitos latitudinais e ambientais, ao invés de conseqüência de rotas migratórias ancestrais (Salzano e Callegari-Jacques 1988).

Abordagem parecida foi utilizada por Cavalli-Sforza, Menozzi e Piazza (1994) e resultados semelhantes foram encontrados: a análise de componentes principais a partir de freqüências de 72 marcadores clássicos distribuídos desde a América do Norte até a América do Sul mostrou que os três primeiros componentes explicavam 52,9\% da variância total observada. Os dois primeiros componentes revelaram claras diferenças entre as porções leste e oeste da América do Sul (Cavalli-Sforza et al. 1994). No mapa resultante do segundo 
componente principal também é possível identificar gradiente ao longo do norte da região amazônica em direção ao leste, com valores se alterando gradativamente a partir do Panamá, em direção à Colômbia, Guianas, Amapá, Pará, até chegar à região central do Brasil (Tocantins), o que é compatível com a hipótese de rota de migração ao longo deste percurso. O terceiro componente mostra um forte gradiente entre o nordeste da América do Sul e o extremo Sul da Cordilheira dos Andes. O quarto componente revela um gradiente oeste-leste. A análise simultânea de todos os componentes principais reforça a hipótese de duas rotas migratórias principais: (a) a partir da porta de entrada do continente sul-americano em direção ao norte e nordeste e (b) ao longo dos Andes em direção ao sul do continente. Entretanto, esta última também se expande a partir da Bolívia e do Peru em direção ao leste (planície amazônica), o que levou os autores a sugerir a possibilidade de fluxo gênico proveniente da vinda de polinésios para as Américas (Cavalli-Sforza et al. 1994). Abordagem alternativa utilizando-se o algoritmo de Monmonnier para identificação de áreas de descontinuidades genéticas abruptas, também revelou diferenças claras entre o leste e oeste sul-americano, o que seria conseqüência de povoamento independente das duas regiões ou de pequenos níveis de fluxo gênico entre elas (relacionado a ambientes e histórias demográficas distintas) (Luiselli et al. 2000).

Enquanto os marcadores clássicos apresentam poucos alelos por locus, os quais estão diretamente sofrendo pressões seletivas, haplogrupos e haplótipos do DNA mitocondrial e do cromossomo Y apresentam maiores níveis de diversidade genética e são menos afetados pelos efeitos da Seleção Natural (embora não fiquem completamente livres de seus efeitos (Mishmar et al. 2003; Elson et al. 2004)). Estas características, associadas às formas de herança sexo-específicas e à ausência de recombinação cromossômica, tornam estes marcadores extremamente informativos para a reconstrução da história populacional feminina e masculina recente (Kittles et al. 1999; Jorde et al. 2000). 
Os maiores níveis de diferenciação entre populações, obtidos pela análise destes marcadores, são esperados, uma vez que as proporções efetivas dos cromossomos Y e do mtDNA são quatro vezes menores do que a de qualquer cromossomo autossômico, o que decorre do fato de cada cromossomo autossômico ser diplóide e transmitido por ambos os sexos (Seielstad et al. 1998; Jorde et al. 2000). Sendo assim, a diferenciação devido à ação da deriva genética e de efeitos de gargalo tende a ocorrer mais rapidamente em mtDNA e Y do que no DNA nuclear, o que permite a identificação de pequenos níveis de heterogeneidade ainda não visíveis pela análise de marcadores clássicos e de DNA autossômico (Jorde et al. 1997; Fay e Wu 1999; Jorde et al. 2000).

Portanto, nesta escala continental, os estudos prosseguiram pela análise do DNA mitocondrial (Fuselli et al. 2003) e microssatélites ligados ao Y (Tarazona-Santos et al. 2001a), para a análise das linhagens femininas e masculinas, respectivamente, sendo que ambos os conjuntos de marcadores revelaram padrões evolutivos e de organização espacial do pool gênico distintos entre populações andinas e não-andinas (provenientes da Bacia Amazônica, planalto central e região dos Chacos). As populações que habitam a parte ocidental (Cordilheira dos Andes) exibem altos níveis de variabilidade genética intra-populacional comparado com aquelas que são encontradas no leste do continente. Além disso, as populações andinas formam um grupo fortemente homogêneo, enquanto que as populações orientais apresentaram maior diferenciação inter-populacional (Tarazona-Santos et al. 2001a; Fuselli et al. 2003). A divergência entre populações da América Central (Panamá) e América do Sul, o que corresponde à entrada dos primeiros ancestrais das populações contemporâneas no continente, foi datada em mais de 13.300 e 18.800 anos atrás (Fuselli et al. 2003), corroborando estimativa anterior (Forster et al. 1996).

O modelo de isolamento-por-distância (IBD, do inglês, isolation-by-distance) foi rejeitado como forma exclusiva para se explicar a variabilidade genética destes marcadores na 
América do Sul, sendo que modelo qualitativo (consistente com evidências culturais, lingüísticas, históricas e demográficas) baseado em padrões regionais mais complexos de deriva genética e fluxo gênico foi proposto: as populações andinas caracterizadas por maior tamanho efetivo populacional e elevadas taxas de fluxo gênico entre elas, tenderiam a apresentar o pool gênico homogeneizado; por outro lado, o menor tamanho efetivo populacional e baixos níveis de fluxo gênico acentuariam os efeitos da deriva genética na porção leste do continente, resultando em grande diversidade inter-populacional (TarazonaSantos et al. 2001a). Este modelo implica em considerar as populações indígenas sul-americanas em dois grupos que evoluem sob taxas distintas. De fato, o modelo IBD poderia explicar a variabilidade genética destes marcadores nos dois grupos analisados separadamente, pelo menos no que diz respeito às linhagens maternas (Fuselli et al. 2003). Todavia, o único revés observado pelos autores em relação a tal modelo vem do fato dos microssatélites do cromossomo $\mathrm{Y}$ não detectarem diferenças significativas entre as populações ocidentais e orientais pela análise de variância molecular (AMOVA), indicando que, embora distribuídos de formas distintas, os mesmos alelos estão presentes em ambas regiões em freqüências semelhantes (Tarazona-Santos et al. 2001a).

Haplogrupos de mtDNA em uma escala geográfica reduzida, restrita à Colômbia, também proporcionam evidências (juntamente com dados históricos e arqueológicos) de que a Cordilheira dos Andes representa uma barreira natural, dividindo o país em duas regiões: noroeste e sudeste (Keyeux et al. 2002). Na região noroeste do país se encontram populações com elevadas freqüências do haplogrupo A e ausência quase que total do haplogrupo D, se assemelhando às populações da América Central. Entretanto, nas populações da região sudeste ocorre uma redução drástica na freqüência do primeiro e incremento significativo na freqüência do segundo, se assemelhando ao restante da América do Sul. Isto levou os autores a proporem que a Colômbia teria sido povoada por pelo menos duas ondas migratórias, uma 
mantendo relações genéticas e culturais com os povos da América Central e outra que teria se diferenciado em grupos mais heterogêneos da Amazônia ao sul do continente (Keyeux et al. 2002).

\subsection{Evidências genéticas e padrões sociais sexo-específicos}

Embora permaneçam muitas incertezas a respeito dos movimentos populacionais realizados pelos ancestrais dos índios contemporâneos na América do Sul, um fato fica evidente pela análise de marcadores de mtDNA: tanto seqüência como haplogrupos se mostraram altamente informativos, apresentando padrão de heterogeneidade geográfica. Uma vez que populações geograficamente mais próximas tendem a experimentar maior fluxo gênico do que populações separadas por maior distância, sendo o grau de isolamento relativo entre as localidades aproximadamente proporcionais às distâncias geográficas (Barbujani 2000), esta heterogeneidade espacial seria esperada. Entretanto, interpretando-se as conclusões alcançadas por Seielstad, Minch e Cavalli-Sforza (1998), discutidas a seguir, haveria motivos para que o padrão de heterogeneidade geográfica deixasse de ser esperado.

Com base em dados de microssatélites autossômicos, polimorfismos do comprimento do fragmento de restrição (RFLP, do inglês, Restriction Fragment Lenght Polymorphism) do DNA mitocondrial e marcadores do cromossomo $\mathrm{Y}$, assumindo-se um tamanho efetivo populacional semelhante entre homens e mulheres, foi proposto que as mulheres em média teriam migrado mais do que os homens ao longo história evolutiva humana (Seielstad et al. 1998), via patrilocalidade (isto é, a tendência da esposa se mudar para a terra natal do marido,

padrão este encontrado em cerca de $70 \%$ das sociedades humanas (Burton et al. 1996)). Poliginia (padrão encorajado por cerca de dois terços das sociedades tradicionais) ou maiores 
taxas de mortalidade masculina (que causariam uma redução no tamanho efetivo populacional masculino) também poderiam contribuir, mas não explicaria totalmente a maior heterogeneidade masculina observada (Seielstad et al. 1998). Apesar das características anteriormente citadas a respeito do mtDNA, se a ocorrência de maiores taxas migratórias femininas constituíssem um padrão nas Américas, dependendo da intensidade destas taxas, poderia resultar na homogeneização das populações e redução da variabilidade inter-populacional, o que por sua vez poderia prejudicar e obscurecer a reconstrução dos movimentos populacionais femininos.

Entretanto, com base na seqüência HV-I do DNA mitocondrial e microssatélites do cromossomo Y, foi observado recentemente maior mobilidade masculina em sociedades matrilocais da Tailândia, enquanto que apenas as patrilocais apresentaram redução de variabilidade do DNA mitocondrial entre populações (Oota et al. 2001). Portanto, visto que na América do Sul aproximadamente metade das sociedades são patrilocais e metade matrilocais (Burton et al. 1996), não é totalmente surpreendente o fato de não terem sido observadas diferenças significativas entre as taxas de migração masculina e feminina entre populações indígenas da Colômbia, bem como entre populações das Américas do Norte, Central e do Sul, usando-se RFLPs do DNA mitocondrial dentre os diversos tipos de marcadores empregados (Mesa et al. 2000; Bortolini et al. 2002; Fuselli et al. 2003). Isto representa suporte significativo à possibilidade dos movimentos biológicos regionais e intra-continentais femininos nas Américas serem reconstruídos e refinados com relativa clareza utilizando-se os haplogrupos de DNA mitocondrial. 


\subsection{Marcadores de DNA em contexto regional: a Amazônia central}

A atenção da comunidade científica inicialmente se voltou para a região centro-oeste da Amazônia brasileira devido à posição central ocupada por estas tribos no continente sul-americano, o que faz com que sejam de grande importância nas tentativas de reconstrução dos movimentos e das relações biológicas entre as tribos da América do Sul (Mohrenweiser et al. 1979). Nesta região, existe particular interesse pela origem e estrutura genética da tribo Tikúna, inicialmente tida como enigmática por se preservar como uma das únicas grandes tribos relativamente puras da Amazônia central (Neel et al. 1980). Tal região é de ocupação mais recente, visto que inicialmente ocuparam a base da Cordilheira dos Andes entre a Colômbia e o Peru (Salzano et al. 1980).

Apesar do grande tamanho populacional e da ampla distribuição geográfica, a tribo Tikúna se apresenta isolada lingüística e geneticamente (Neel et al. 1980; Salzano et al. 1980). Trabalhos recém desenvolvidos (Oliveira 1999; Mendes-Junior 2001; Wanderley-Santos 2001; Luizon 2003) têm confirmado sistematicamente este isolamento tribal dos Tikúna relatado há mais de duas décadas. Povos de língua Arawak (língua falada pelos Baníwa) por muito tempo atuaram como barreira física evitando o acesso dos Tikúna a dois grandes rios (Putumayo-Iça e Solimões), o que dificultou o contato dos Tikúna com não-indígenas; em caso de ter havido eventual ocorrência de rompimento deste isolamento tribal, as posições geográficas ocupadas pelos Arawak os tornariam potenciais candidatos à troca de genes com os índios Tikúna. Embora baseados em dados oriundos de apenas quatro das oito aldeias Tikúna inicialmente amostradas, estudos de marcadores de DNA demonstraram ocorrência de fluxo gênico entre elas que ocasionou forte homogeneidade das aldeias da tribo Tikúna (Oliveira 1999; Mendes-Junior 2001; Wanderley-Santos 2001), o que corrobora informações sócio-demográficas sobre estímulo à prática de exogamia intra-tribal (Salzano et al. 1980). 
Nesta região também habitam determinadas tribos que são muitas vezes reconhecidas pelo grupo lingüístico (Pano) a que pertencem (Mohrenweiser et al. 1979; Salzano e Jacques 1979), estando entre elas os Katukina, Kaxináwa, Marúbo e Yaminawa. Os Pano se originaram de populações ancestrais que habitavam localidades do Equador situadas na porção oriental da Cordilheira dos Andes (Salzano e Jacques 1979). Devido a várias razões, tiveram que migrar em direção ao sul e no final do século 17 já podiam ser encontrados em vasta região delimitada pelos Rios Marañon e Ucayali. A partir desta região, foram para o leste em direção aos Rios Juruá e Purus, estabelecendo-se no sudoeste do estado do Amazonas, Oeste do Acre e em porções adjacentes do Peru. Passaram então a sofrer uma série de fissões que deram origem às tribos Pano atuais (Salzano e Jacques 1979). Quando se considera sua grande extensão territorial, a área Pano atrai a atenção por sua homogeneidade étnica excepcional, reforçada por coesão lingüística e cultural igualmente notável (Erikson 1998). Análise lingüística baseada na densidade de cognatos revelou que o nível de inteligibilidade é maior do que o encontrado entre as várias subdivisões da tribo Yanomama (Mohrenweiser et al. 1979), razão pela qual todos estes grupos são considerados como parte de uma mesma tribo. Os padrões de casamento da aldeia Katukina Morada Nova envolveram indivíduos Katukina, Kaxináwa e Yaminawa, contrastando com o fato de que nas aldeias Kaxináwa Cana Brava e Paredão a ocorrência de casamentos inter-tribais é praticamente nula (Salzano e Jacques 1979).

Embora apresentem estas características, a estrutura genética dos Pano não foi adequadamente abordada até o presente. Uma das poucas conclusões relevantes, obtida pela análise de marcadores clássicos, é a existência de heterogeneidade entre Kaxináwa e Katukina duas vezes maior do que entre populações Kaxináwa do Brasil e do Peru (Mohrenweiser et al. 1979; Salzano e Jacques 1979; Mestriner et al. 1980). Até o momento, marcadores de DNA foram analisados apenas nas aldeias brasileiras Cana Brava e Paredão da tribo Kaxináwa, 
sendo que os resultados obtidos indicam homogeneidade maior até mesmo do que a observada entre as aldeias da tribo Tikúna (Mendes-Junior 2001; Wanderley-Santos 2001; Luizon 2003). Embora esta conclusão seja relevante, cabe ressaltar que esta homogeneidade pode ser decorrente simplesmente do fato de tais aldeias estarem separadas por distância insignificante e de os habitantes de uma possuírem parentes na outra (Salzano e Jacques 1979), não sendo assim representativa do padrão de homogeneidade (ou heterogeneidade) das aldeias e tribos Pano. 


\section{Hipótese}

Por se tratar de tribo organizada em comunidades patrilocais, eventual rompimento de isolamento tribal dos Tikúna seria certamente mediada pelas mulheres, na forma de chegada de mulheres de outras tribos e de migração de mulheres Tikúna para se casarem com homens de outras tribos. Sendo assim, a análise de DNA mitocondrial é imprescindível para se confirmar o isolamento tribal dos Tikúna. Dando continuidade a este raciocínio, a homogeneidade entre as aldeias Tikúna deve se mostrar mais acentuada pela análise destes marcadores, uma vez que na prática de exogamia intra-tribal a tendência é de que as mulheres deixem sua aldeia natal para se juntarem aos seus maridos de outras aldeias Tikúna, resultando-se assim na homogeneização do material genético feminino dentro da tribo como um todo.

Por outro lado, embora seja considerado lingüística e culturalmente homogêneo, o grupo Pano se apresenta fragmentado na forma de tribos ou conjunto de tribos, o que leva a supor o ajustamento a uma estrutura hierárquica na qual as aldeias de mesma tribo (Kaxináwa e Katukina) tendem a se apresentar homogêneas (o que é esperado em vista dos dados históricos e demográficos), enquanto que aldeias de tribos distintas tendem a apresentar menor homogeneidade ou até mesmo heterogeneidade genética significativa.

A comparação entre os Tikúna e os Pano poderá contribuir para identificação de fatores que influenciam na evolução e divergência das populações indígenas da Amazônia central, uma vez que constituem grupos distintos em termos de estrutura social, organização tribal, afiliação lingüística e distribuição geográfica.

Este trabalho também foi norteado por uma hipótese mais abrangente de que o padrão espacial de distribuição dos haplogrupos de mtDNA pelas aldeias e tribos amplamente 
difundidas pelo continente permite analisar a estrutura genética em diferentes níveis hierárquicos, testar modelos evolutivos e correlacionar os achados com as propostas anteriores de possíveis rotas migratórias dentro da América do Sul, proporcionando uma visão geral da história populacional feminina recente dos indígenas sul-americanos. 


\section{Justificativa}

Apesar dos esforços, é ainda um mistério a(s) rota(s) migratória(s) percorrida(s) pelos primeiros Ameríndios a povoarem a Amazônia central (Salzano e Callegari-Jacques 1988; Cavalli-Sforza et al. 1994; Tarazona-Santos et al. 2001a; Fuselli et al. 2003). Embora não sejam poucas as populações já analisadas (Salzano 2002), existe clara necessidade de ampliação de dados relativos a haplogrupos de DNA mitocondrial na região centro-oeste da Amazônia brasileira. A posição central ocupada por estas populações na América do Sul, faz ainda com que sejam informativas nas tentativas de reconstruir os movimentos e as relações biológicas entre as tribos da América do Sul (Mohrenweiser et al. 1979). Além disso, a região a ser estudada é carente em sítios arqueológicos (Salzano e Callegari-Jacques 1988; Fiedel 2000), o que torna a análise genética de populações contemporâneas isoladas a forma mais adequada (e talvez única) de se obter inferências confiáveis sobre as rotas migratórias nesta região.

O grande número de populações nas quais estes haplogrupos foram analisados e a ampla extensão geográfica abrangida por tais populações faz com que estes marcadores constituam provavelmente o mais amplo banco de dados de informações moleculares disponíveis no continente sul-americano. Isto os torna ferramenta de extremo valor para a obtenção de informações sobre a história populacional dos nativos americanos, permitindo que sejam utilizados para se testar hipóteses e modelos evolutivos. 


\section{Objetivos}

O objetivo geral consiste em levantar freqüências alélicas de conjuntos de marcadores ligados ao DNA mitocondrial em amostras de populações indígenas brasileiras, totalizando 308 indivíduos distribuídos entre 16 aldeias pertencentes a oito tribos, o que permitirá:

- analisar a estrutura genética feminina dos indígenas brasileiros nos níveis infra-tribal (nas tribos Katukina, Kaxináwa e Tikúna), tribal e lingüístico, a fim de contribuir para o entendimento da unidade evolutiva ameríndia.

- identificar eventual presença do haplogrupo X em indígenas do centro-oeste amazônico.

- quantificar a contribuição feminina européia e africana para o pool gênico das populações indígenas da região centro-oeste da Amazônia brasileira.

- realizar análise comparativa entre os resultados aqui encontrados com dados de haplótipos de microssatélites ligados ao cromossomo Y (os quais trazem informações complementares, a respeito da história populacional masculina recente) obtidos em parte das populações aqui analisadas (Wanderley-Santos 2001).

- juntamente com dados disponíveis na literatura, testar modelos evolutivos e rotas migratórias anteriormente propostas dentro da América do Sul e/ou inferir novas rotas. 


\section{Material e Métodos}

\subsection{Amostras populacionais indígenas}

Amostras de sangue de mais de 2.500 indivíduos pertencentes a 16 aldeias das tribos Baníwa, Kanamarí, Katukina, Kaxináwa, Marúbo Yaminawa e Tikúna foram coletadas no ano de 1976, em expedição à região central da Amazônia (posteriormente denominada Alpha Helix devido ao nome do navio de pesquisas cujas instalações foram utilizadas), na qual o Prof. Dr. Aguinaldo Luiz Simões teve participação intensiva. Dados sócio-demográficos foram obtidos em pelo menos metade destas aldeias (Salzano e Jacques 1979; Salzano et al. 1980) e grande quantidade de marcadores clássicos (imunoglobulinas, grupos sangüíneos, proteínas séricas e eritrocitárias) foi analisada em todas estas populações a cerca de 25 anos atrás (Gershowitz e Neel 1978; Mohrenweiser et al. 1979; Mestriner et al. 1980; Neel et al. 1980; Simões 1980). A estrutura populacional de indígenas da Amazônia, pertencentes a aldeias das tribos Baníwa (Jandu Cachoeira), Kanamarí (Três Unidos), Kaxináwa (Cana Brava e Paredão) e Tikúna (Belém, Feijoal, Umariaçu e Vendaval), vem sendo intensivamente estudada neste laboratório nos últimos anos, por meio de diferentes marcadores de DNA: inserções Alu (Oliveira 1999) microssatélites autossômicos e ligados ao cromossomo Y (Mendes-Junior 2001; WanderleySantos 2001) e alelos população-específicos (PSAs, do inglês, Population Specific Alleles) (Luizon 2003).

Amostras de 161 homens destas aldeias, juntamente com outros 147 pertencentes às outras oito aldeias coletadas (das tribos Tikúna, Katukina, Marúbo e Yaminawa) serão aqui estudadas. Estes 308 indivíduos foram selecionados com a intenção de se obter o menor grau de parentesco possível. Segue abaixo descrição sucinta sobre estas tribos. 
Baníwa. Esta tribo de língua Arawak ocupa área drenada pelo Rio Içana (tributário do Rio Negro) no extremo Noroeste do Estado do Amazonas, próxima ao território colombiano. Estimativas em 1976 indicavam a existência de aproximadamente 1.500 indígenas distribuídos em 16 aldeias. Organizavam-se em 20 clãs exogâmicos patrilineares e já podiam ser considerados semi-aculturados (Mohrenweiser et al. 1979). Em censo realizado em 2002 foi observado grande aumento populacional, tendo sido atingida a marca de 5.141 indivíduos em território brasileiro (Instituto Socioambiental 2003b). As amostras obtidas foram coletadas na aldeia Jandu Cachoeira (situada na parte superior do Rio Içana), sendo que membros de outras cinco aldeias se encontravam ali presentes e também participaram da coleta e vacinação (Simões 1980).

Kanamarí. Esta tribo de língua isolada Katukina é encontrada na região das bacias dos Rios Juruá e Purus, no Sudoeste do Estado do Amazonas. Na época da coleta esta pequena tribo era composta por cerca de 800 pessoas divididas em nove aldeias cujos membros praticavam agricultura de subsistência e apresentavam longa história de contato com neo-brasileiros (Mohrenweiser et al. 1979). Apesar disto, até mesmo a ocorrência de casamentos inter-tribais não ocorriam (Salzano e Jacques 1979). Censo realizado em 1999 já computava a existência de 1.327 indivíduos (Instituto Socioambiental 2003b). As amostras aqui analisadas foram coletadas na aldeia Três Unidos no Igarapé Mamoré, afluente do Rio Juruá (Mohrenweiser et al. 1979).

Katukina. Esta tribo de língua Pano apresentava na época da coleta cerca de 700 indivíduos, habitantes do Estado do Acre (Mestriner et al. 1980). A tribo Katukina foi a única dentre as sete tribos estudadas que experimentou redução populacional desde a época da coleta, visto que no ano 1998 restavam apenas 318 índios Katukina (Instituto Socioambiental 2003b). Embora a organização social atual seja patrilinear, até poucos anos atrás a matrilinearidade era predominante (Instituto Socioambiental 2003a). Apresentam longa história de contato com 
neo-brasileiros. Foram coletadas amostras em duas aldeias: Morada Nova (às margens do Rio Embira) e Sete Estrelas (às margens do Rio Juruá) (Salzano e Jacques 1979; Mestriner et al. 1980; Simões 1980). Morada Nova é na realidade uma aldeia formada pela mistura de indivíduos provenientes de três tribos Pano (Kaxináwa, Katukina e Yaminawa) que desejavam se estabelecer em localidade mais próxima à cidade de Feijó, sendo que $12 \%$ dos adultos que habitam nesta aldeia são de ancestralidade não-indígena (Mohrenweiser et al. 1979; Salzano e Jacques 1979).

Kaxináwa. Esta tribo de língua Pano se distribui pelo extremo sudoeste do Estado do Amazonas e metade do estado do Acre. Na época da coleta totalizavam cerca de 2 mil indivíduos habitando as margens do Rio Embira e seus tributários (Salzano e Jacques 1979; Mestriner et al. 1980). Estimativas de 1999 apontavam a existência de cerca de 3.964 membros desta tribo em território brasileiro (Instituto Socioambiental 2003b). O sistema de organização social é patrilinear (Instituto Socioambiental 2003a), enquanto que o grau de aculturação desta tribo é bastante variado (Mohrenweiser et al. 1979; Simões 1980). As amostras obtidas foram coletadas nas aldeias e Cana Brava e Paredão (Mestriner et al. 1980), duas aldeias interconectadas de modo que os habitantes de uma possuem parentes na outra (Salzano e Jacques 1979)

Marúbo. Dentre os grupos de língua Pano aqui estudados, os Marúbo são os únicos que permanecem culturalmente intactos e relativamente não-aculturados. Dentre os rituais característicos destacam-se o endo-canibalismo e a cremação dos mortos (Mohrenweiser et al. 1979). Em 1976 cerca de 400 membros desta tribo se distribuíam pela região dos Rios Ituí e Curuçá, na região sudoeste do Estado do Amazonas (Mestriner et al. 1980). Em 2000 totalizavam 1043 indivíduos (Instituto Socioambiental 2003b). Se organizam em nove clãs exogâmicos matrilineares, sendo que membros de dois ou mais clãs habitam mesma 
residência. A coleta foi realizada apenas na aldeia Vida Nova (Mohrenweiser et al. 1979; Simões 1980).

Yaminawa. Esta tribo de língua Pano habita o Estado do Acre, apresentando hoje cerca de 618 indivíduos em território brasileiro, de acordo com censo de 1999 (Instituto Socioambiental 2003b), enquanto que na época da coleta eram contabilizados cerca de 410 membros desta tribo (Mestriner et al. 1980). A organização social se baseia em poligamia, endogamia e matrilocalidade (Instituto Socioambiental 2003a). A coleta foi realizada em localidade nas margens do Rio Juruá, a seis quilômetros da aldeia Katukina de Sete Estrelas (Mohrenweiser et al. 1979).

Tikúna. Esta tribo de língua isolada do subgrupo lingüístico Macro-Tucanoan são provavelmente o maior grupo de descendentes de uma única tribo que ainda vive no Brasil, habitando o Estado do Amazonas; representantes dos Tikúna também podem ser encontrados em territórios peruano e colombiano. $\mathrm{Na}$ época da coleta, só em território brasileiro, havia cerca de 11 mil membros desta tribo (Salzano e Jacques 1979). Censo de 1998 apontou a existência de 32.613 membros desta em território brasileiro (Instituto Socioambiental 2003b), o que confirma as indicações de que se encontravam em ascensão demográfica (Salzano et al. 1980). Embora apresentem contatos com não-indígenas a cerca de três séculos, esta tribo ainda mantém a sua identidade étnica e casamentos com pessoas de fora são raros; organizam-se socialmente na forma de duas metades exogâmicas patrilineares (Salzano e Jacques 1979). Foram amostradas as aldeias Belém, Bom Jardim, Campo Alegre, Feijoal, Marajá, Nova Itália, Umariaçu e Vendaval, as quais se localizam ao longo do Rio Solimões (Neel et al. 1980; Salzano et al. 1980)

Estas sete tribos falam línguas pertencentes a dois estoques lingüísticos (Greenberg 1987): Ge-Pano-Carib (Katukina, Kaxináwa, Marúbo e Yaminawa), e Equatorial-Tucanoan 
(Baníwa, Kanamarí e Tikúna). Algumas das línguas faladas por estas tribos não se relacionam claramente a nenhuma outra, mesmo quando pertencentes ao mesmo grupo lingüístico, como é o caso da língua falada pelos Tikúna (Neel et al. 1980) e Kanamarí (Mohrenweiser et al. 1979). De modo geral, a análise dos polimorfismos clássicos revelou que todas estas populações apresentam níveis de mistura inter-étnica definitivamente inferiores a 5\% (Neel et al. 1980), sendo que a grande maioria das estimativas resultou em valores ao redor de $1 \%$ ou até mesmo nulos (Gershowitz e Neel 1978; Mohrenweiser et al. 1979; Salzano e CallegariJacques 1988; Callegari-Jacques e Salzano 1999). Outras informações podem ser encontradas em trabalhos anteriores (Gershowitz e Neel 1978; Mohrenweiser et al. 1979; Salzano e Jacques 1979; Mestriner et al. 1980; Neel et al. 1980; Salzano et al. 1980; Simões 1980).

Para facilitar o entendimento e evitar confusões entre tribos e aldeias, nomes de tribos estarão sempre em formato itálico, enquanto que nomes de aldeias estarão sempre em formato não-itálico. As localizações geográficas aproximadas de todas as 16 aldeias estão representadas na Figura 1.

\subsection{Aspectos éticos}

O projeto de pesquisa do presente trabalho foi aprovado em seus aspectos éticos pela Comissão de Ética em Pesquisa da Instituição (Hospital das Clínicas - FMRP, USP) de acordo com o processo HCRP n ${ }^{\circ} 7869 / 2004$, e também pela Comissão Nacional de Ética em Pesquisa (CONEP) segundo processo $\mathrm{n}^{\mathrm{o}}$ 25000.120707/2004-02.

Todas as populações envolvidas foram visitadas e tiveram suas amostras de sangue colhidas anteriormente, durante o desenvolvimento de projetos mais antigos do que a resolução CNS 196/96 do Ministério da Saúde. Mesmo assim, todos eles, à sua época e na 
forma adequada, seguiram rigorosamente os preceitos de (a) informação prévia dos participantes e seus líderes comunitários, (b) aquiescência voluntária, (c) garantia de anonimato dos participantes, sendo a "Expedição Alpha Helix" aprovada segundo processo FUNAI/BSB/4854/75 e autorizações 26/76, 27/76, 74/76 e 75/76. Banco de amostras intitulado Alpha Helix foi criado e reconhecido de acordo com processo HCRP nº 9367/2003.

\subsection{Coleta de amostras}

As amostras de sangue utilizadas neste estudo foram coletadas em 1976, durante a "Expedição Alpha Helix", em tubos "vacutainers" contendo 2,0 ml de anticoagulante ACD e foram refrigeradas cerca de 12 horas após a coleta. Cerca de três dias após a coleta este material foi processado para estocagem. Em tubo apropriado, as amostras foram centrifugadas (1.500 rpm, durante 10 minutos) e o plasma foi retirado. As hemácias foram então lavadas três vezes em solução salina isotônica, e o sedimento resultante após a última centrifugação foi ressuspenso em igual volume de solução de glicerol a $40 \%$ em tampão de estocagem $(32,5 \mathrm{~g}$ de citrato de tripotássio $+6,0 \mathrm{~g}$ de fosfato bibásico de potássio $+4,7 \mathrm{~g}$ de fosfato monobásico de potássio + água destilada qsp. 1 litro). As amostras foram então mantidas a $-20^{\circ} \mathrm{C}$ até o presente. Descrição detalhada encontra-se em Simões (1980).

\subsection{Extração de DNA}

A extração de DNA foi feita a partir da fração de hemácias descritas em item anterior, visto que uma pequena quantidade de leucócitos permaneceu misturada nesta fração, a partir de uma adaptação de método proposto (Higuchi 1989). 

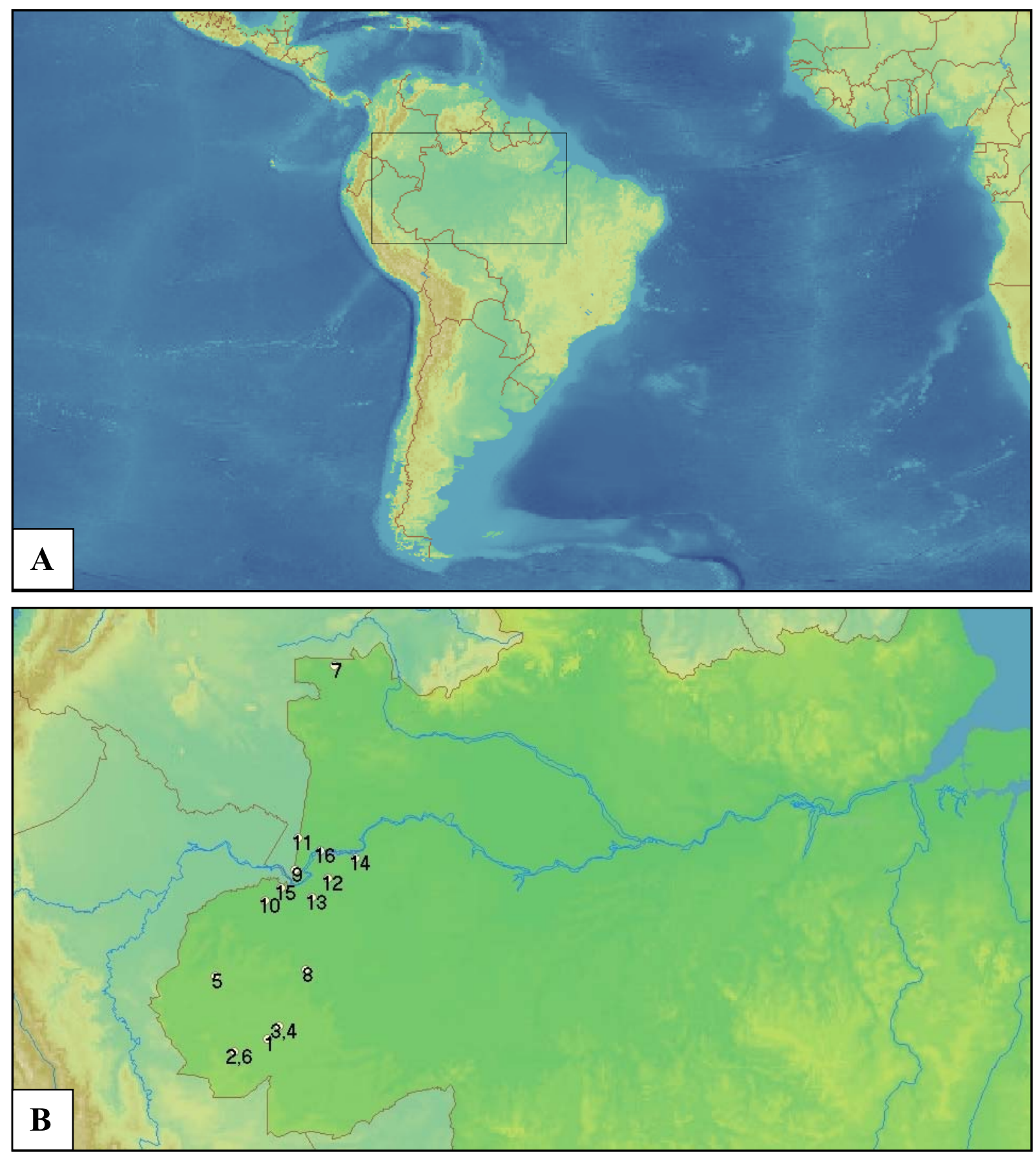

Figura 1. (A) Mapa do continente sul-americano. (B) Mapa da região Amazônica (destacada no mapa sulamericano) indicando a localização geográfica aproximada das 16 aldeias pertencentes às sete tribos aqui estudadas. Legenda: (1) Katukina - Morada Nova; (2) Katukina - Sete Estrelas; (3) Kaxináwa - Cana Brava; (4) Kaxináwa - Paredão; (5) Marúbo - Vida Nova (6) Yaminawa; (7) Baníwa - Jandu Cachoeira; (8) Kanamarí Três Unidos; (9) Tikúna - Belém; (10) Tikúna - Bom Jardim; (11) Tikúna - Campo Alegre; (12) Tikúna Feijoal; (13) Tikúna - Marajá; (14) Tikúna - Nova Itália; (15) Tikúna - Umariaçu; (16) Tikúna - Vendaval.

Entre 50 e $500 \mu \mathrm{l}$ de cada amostra é colocada em microtubo de 1,5 ml, utilizando-se uma micropipeta e ponteiras estéreis. Em seguida, adiciona-se 1,0 $\mathrm{ml}$ de tampão de lise de 
eritrócitos (Tris/ $\mathrm{HCl}$ 0,01 M pH 7,6; sacarose 0,32 M; $\mathrm{MgCl}_{2}$ 5,0 mM; e Triton X-100 1\%) a cada microtubo. Homogeneíza-se a mistura e centrifuga-se o conteúdo dos microtubos a $12.000 \mathrm{rpm}$ durante 5 minutos. Retira-se o sobrenadante e acrescenta-se novamente $1,0 \mathrm{ml}$ de tampão de lise de eritrócitos ao precipitado avermelhado. Homogeneíza-se e centrifuga-se cada microtubo novamente. Estes procedimentos são repetidos caso o precipitado não tenha adquirido cor branca, indicando a presença de leucócitos e ausência de hemácias.

Por fim, retira-se o sobrenadante, suspende-se o precipitado em $300 \mu 1$ de tampão de lise de leucócitos (Tris/HCl 0,01M pH 8,5; $\mathrm{KCl} 50 \mathrm{mM} ; \mathrm{MgCl}_{2}$ 2,5 mM; NP-40 0,45\%; Tween 20 0,45\%), e adiciona-se $5 \mu \mathrm{l}$ de proteinase $\mathrm{K}(10 \mathrm{mg} / \mathrm{ml})$, em cada microtubo. As amostras devem ser colocadas em estufa a $65^{\circ} \mathrm{C}$ por período de 1 hora, e em seguida transferidas para estufa a $37^{\circ} \mathrm{C}$ por período de aproximadamente 12 horas. As amostras devem então ser armazenadas em refrigerador com temperatura aproximada de $-4^{\circ} \mathrm{C}$.

\subsection{Polimorfismos do DNA mitocondrial}

\subsubsection{Panorama geral sobre o mtDNA}

O DNA mitocondrial constitui em uma molécula de DNA circular de dupla hélice, constituída por 16.569 pares de base, encontrada no interior das mitocôndrias (Wallace 1995; Scheffler 1999). Dois RNAs ribossômicos, 22 RNAs transportadores e 13 polipeptídeos são codificados pelo mtDNA e atuam diretamente na síntese de ATP (fosforilação oxidativa). O número de mitocôndrias por célula varia significativamente de acordo com o tipo de célula e função biológica que exerce, variando de algumas centenas a alguns milhares destas organelas por células (o hepatócito, por exemplo, possui cerca de 800 mitocôndrias) (Scheffler 1999). Cada 
célula humana apresenta, portanto, milhares de moléculas de mtDNA. Estima-se que o ovócito humano contenha cem mil mitocôndrias, enquanto que o espermatozóide apresenta menos de cem destas organelas (excepcionalmente grandes, oriundas da fusão de múltiplas delas) localizadas em sua região caudal (Scheffler 1999; Eyre-Walker e Awadalla 2001).

As mitocôndrias masculinas normalmente não chegam a penetrar no óvulo durante a fecundação, mas existem mecanismos para destruição da mitocôndria e do mtDNA paternos quando estes conseguem penetrar no óvulo (Eyre-Walker e Awadalla 2001). Entretanto, a identificação de um caso comprovado de herança materna e paterna demonstra que tais mecanismos não são infalíveis (Schwartz e Vissing 2002). A análise do mtDNA de diferentes tecidos deste indivíduo demonstrou também a ocorrência de recombinação entre as moléculas de mtDNA materna e paterna (Kraytsberg et al. 2004), o que acirrou ainda mais as discussões sobre a possibilidade de tais recombinações ocorrerem em células gaméticas e serem herdáveis (Eyre-Walker e Awadalla 2001; Slate e Gemmell 2004).

Apesar desta exceção relatada, o DNA mitocondrial é herdado pelos filhos e filhas a partir de suas mães, caracterizando padrão de herança matrilinear. Durante a produção de células germinativas femininas, ao surgir uma nova mutação no mtDNA em uma de tais células, é criada uma mistura intracelular de moléculas normais e mutantes, conhecida como heteroplasmia. Quando esta célula se divide, existe a possibilidade desta mutação ser transmitida para as próximas células filhas e ser herdada pelos novos indivíduos. Uma vez que o mtDNA apresenta taxas evolutivas (taxa de mutação x taxa de fixação) de 10 a 20 vezes maiores que o DNA nuclear, grande quantidade de mutações neutras (ou pouco deletérias) é produzida, tendo sido acumuladas nas linhagens femininas ao longo de dezenas de milhares de anos. 
Admitindo-se que não ocorra recombinação entre as moléculas de mtDNA, o número de diferenças entre as seqüências de mtDNA de dois indivíduos é proporcional ao tempo transcorrido desde o momento em que compartilharam seu último ancestral comum (Wallace 1995). Mutações neutras foram ocorrendo enquanto as mulheres se irradiavam da África para os vários continentes durante os cerca de 150 mil anos de evolução humana, de modo que a distribuição geográfica de tais mutações acumuladas seqüencialmente nas linhagens de mtDNA reflete a pré-história feminina (Wallace 1995). A análise de populações contemporâneas mundialmente distribuídas revela a existência de grupos de linhagens (haplogrupos) que apresentam mutações associadas à origem étnica e geográfica (Forster 2004). Os haplogrupos L1, L2 e L3, por exemplo, se encontram restritos à África ou a populações afro-derivadas, enquanto que os haplogrupos $\mathrm{H}, \mathrm{I}, \mathrm{J}, \mathrm{T}, \mathrm{U}, \mathrm{V}$ são característicos de populações européias ou euro-descendentes (Forster 2004). Os cinco haplogrupos de mtDNA fundadores do continente americano (A, B, C, D e X) também são encontrados na Ásia, sendo o B e o X também encontrados na Polinésia e Europa, respectivamente (Lum et al. 1994; Reidla et al. 2003; Forster 2004).

\subsubsection{Marcadores polimórficos estudados}

Foram estudados cinco marcadores que definem os haplogrupos ameríndios A (+663 HaeIII), B (Deleção 9pb), C (-13259 HincII) D (-1571 AluI) X (-1715 DdeI) e um que define haplogrupo africano L (+3592 HpaI). (Tabela 1). O haplogrupo B é identificado por uma deleção de 9 pares de base na região V (região não-codificadora entre o gene da citocromo oxidase II e do gene tRNA ${ }^{\text {Lys }}$ ) (Lorenz e Smith 1994) enquanto que os outro cinco haplogrupos são identificados pela presença ou ausência de sítios de restrição em posições específicas (Tabela 1). 
Os marcadores relativos aos haplogrupos A e B foram testados em todos os 308 indivíduos, sendo que nenhum deles demonstrou a sobreposição de haplogrupos. Desta forma os marcadores que definem os haplogrupos $\mathrm{C}$ e $\mathrm{D}$ foram analisados em todos os 184 indivíduos restantes (não identificado como A ou B), e novamente não houve sobreposições. Por fim, os marcadores que caracterizam os haplogrupos X e L foram analisados apenas em um indivíduo cujo haplogrupo não foi identificado pela análise dos quatro marcadores previamente utilizados.

Tabela 1 - Descrição dos primers, temperaturas de pareamento $\left(T_{P}\right)$ utilizadas para a amplificação por PCR e tamanhos dos fragmentos obtidos após a PCR e após a reação de restrição (RFLP).

\begin{tabular}{|c|c|c|c|c|c|c|c|}
\hline Hap $^{1}$ & $\begin{array}{l}E R^{2}- \\
\text { Marcador }\end{array}$ & Primers & Seqüência $\left(5^{\prime} \rightarrow 3\right.$ ') & $\begin{array}{c}T_{P} \\
\left({ }^{\circ} \mathrm{C}\right)\end{array}$ & $P C R$ & RFLP & Ref. ${ }^{4}$ \\
\hline \multirow[t]{2}{*}{ A } & HaeIII- & L611 & ACCTCCTCAAAGCAATACACTG & 52 & 176 & 101, & 1,2 \\
\hline & 663 & H743 & GTGCTTGATGCTTGTTCCTTTTG & & & 75 & \\
\hline \multirow[t]{2}{*}{ B } & Del 9pb ${ }^{3}$ & L8215 & ACAGTTTCATGCCCATCGTC & 50 & $121(-)$ & - & 1,2 \\
\hline & & H8297 & ATGCTAAGTTAGCTTTACAG & & $112(+)$ & & \\
\hline \multirow[t]{2}{*}{$\mathrm{C}$} & HincII- & L13232 & CGCCCTTACACAAAATGACATCAA & 50 & 211 & 158, & 1,2 \\
\hline & 13259 & H13393 & TCCTATTTTTCGAATATCTTGTTC & & & 53 & \\
\hline \multirow[t]{2}{*}{$\mathrm{D}$} & AluI- & L5120 & TAACTACTACCGCATTCCTA & 52 & 149 & 77 , & 1,2 \\
\hline & 5176 & $\mathrm{H} 5230$ & AAAGCCGTTAGCGGGGGCA & & & 72 & \\
\hline \multirow[t]{2}{*}{$\mathrm{X}$} & DdeI- & A1715 & CCAGAGTGTAGCTTAACAC & 55 & 292 & 114, & 2 \\
\hline & 1715 & B1715 & TTTGGCTCTCCTTGCAAAG & & & 178 & \\
\hline \multirow[t]{2}{*}{$\mathrm{L}$} & HpaI- & 5'3238 & CCCAAGAACAGGGTTTGTTAAGATG & 49 & 589 & 381 , & 2 \\
\hline & 3592 & 3'3779 & ATAAGGGTGGAGAGGTTAAAGGAGC & & & 208 & \\
\hline
\end{tabular}

\footnotetext{
${ }^{1}$ Hap: Haplogrupo do mtDNA;

${ }^{2}$ ER: Enzima de Restrição para diagnóstico do haplogrupo;

${ }^{3} \mathrm{O}$ diagnóstico do haplogrupo $\mathrm{B}$ não requer reação de restrição;

${ }^{4}$ Referências: 1- Stone e Stoneking (1993); 2- Keyeux et al (2002).
} 


\subsection{Reação em Cadeia da Polimerase (PCR)}

Para amplificação dos polimorfismos do mtDNA nesta amostra com DNA genômico relativamente escasso foi utilizada a técnica de PCR (Mullis et al. 1986). A reação de PCR foi feita separadamente para cada marcador, utilizando-se misturas de reação e regimes de temperaturas muito semelhantes.

Inicialmente, alíquotas de 4,0 $\mu \mathrm{l}$ de DNA genômico são submetidas a programa de desnaturação $\left(10\right.$ minutos a $\left.94^{\circ} \mathrm{C}\right)$, a fim de que ocorra a inativação da proteinase $\mathrm{K}$. Em seguida, adiciona-se a mistura de reação da PCR a cada amostra:

- Água deionizada em quantidade específica para o marcador analisado:

$$
\begin{aligned}
& 17,7 \mu \mathrm{l} \rightarrow \text { HaeIII } 663 \text { e HincII 13259; } \\
& 17,6 \mu \mathrm{l} \rightarrow \text { Del 9pb, AluI } 5176 \text { e DdeI 1715; } \\
& 17,4 \mu \mathrm{l} \rightarrow \text { HpaI 3592; }
\end{aligned}
$$

- Solução de primers forward e reverse $(2,5 \mu \mathrm{M})$ específica para o marcador analisado, em quantidade específica:

$$
\begin{aligned}
& 0,3 \mu \mathrm{l} \rightarrow \text { HaeIII } 663 \text { e HincII 13259; } \\
& 0,4 \mu \mathrm{l} \rightarrow \text { Del 9pb, AluI } 5176 \text { e DdeI 1715; } \\
& 0,6 \mu \mathrm{l} \rightarrow \text { HpaI 3592; }
\end{aligned}
$$

- $\quad$ 2,5 $\mu \mathrm{l}$ de tampão de reação (Tris/ $\mathrm{HCl} 75$ mM pH 9,0; KCl 50 mM; $\left(\mathrm{NH}_{4}\right)_{2} \mathrm{SO}_{4} 20$ mM; $\left.\mathrm{MgCl}_{2} 2,0 \mathrm{mM}\right)$;

- $\quad 0,25 \mu 1$ de solução de dNTP (20 mM de cada dNTP: dATP, dCTP, dGTP, dTTP);

- $0,25 \mu \mathrm{l}$ de Taq polimerase $(1 \mathrm{U} / \mu \mathrm{l})$.

As amostras são então submetidas a regimes de temperaturas que consistem em:

- 5 minutos a $94^{\circ} \mathrm{C}$;

- 40 ciclos de: (a) 45 segundos a $94^{\circ} \mathrm{C}$, (b) 45 segundos em temperaturas de pareamento específicas (Tabela 1) e (c) 45 segundos a $72^{\circ} \mathrm{C}$;

- 5 minutos a $72^{\circ} \mathrm{C}$. 
Os primers utilizados para a amplificação dos marcadores utilizados neste trabalho foram sintetizados pela Bio-synthesis e suas seqüências estão descritas na Tabela 1.

\subsection{Reação de restrição}

Após a amplificação do DNA genômico por PCR, o produto da reação dos marcadores que definem os haplogrupos A, C, D, X e L foram submetidos a reação de clivagem utilizando-se enzimas de restrição sítio-específicos (Tabela 1).

$\mathrm{Na}$ análise de cada marcador, $3,0 \mu \mathrm{l}$ do produto de PCR de cada amostra foi pipetado em microtubos, nos quais foram adicionados a mistura de reação de clivagem:

- $6 \mu 1$ de água deionizada;

- $1 \mu 1$ de tampão de reação específico para cada enzima;

- $2 \mathrm{U}$ de enzima de restrição sítio-específica $(10 \mathrm{U} / \mu \mathrm{l})$.

As amostras são então mantidas a $37^{\circ} \mathrm{C}$ por período de aproximadamente 14 horas. Cada uma das enzimas, juntamente com o tampão correspondente, foi produzida pela Invitrogen - life technologies.

\subsection{Eletroforese em gel de poliacrilamida}

Os produtos da reação de PCR (no caso da deleção de 9pb) ou da reação de restrição (no caso dos demais marcadores) foram analisados através da separação eletroforética em gel de poliacrilamida $8 \%$ não-desnaturante, preparado através da mistura dos seguintes componentes: 
- 2,667 $\mathrm{ml}$ de água deionizada;

- 5,528 $\mathrm{ml}$ de acrilamida + bis-acrilamida $(29 \mathrm{~g}$ de acrilamida recristalizada $+1 \mathrm{~g}$ de bisacrilamida recristalizada, diluídas em $100 \mathrm{ml}$ de água deionizada);

- $\quad 0,7 \mathrm{ml}$ de glicerol;

- 1,0 ml de tampão TBE 10x (pH 8,0 - 108 g de Tris + 53 g de Ácido Bórico + 7,44 g de EDTA, diluídos em 1 litro de água deionizada)

- $\quad$ 7,5 $\mu 1$ de TEMED (N, N, N’, N', tetrametiletilenodiamina);

- $150 \mu \mathrm{l}$ de persulfato de potássio $[100 \mathrm{mg} / \mathrm{ml}$.

Após a polimerização do gel, este é colocado em uma cuba de eletroforese vertical, contendo tampão TBE 1x (o mesmo utilizado para a preparação do gel, diluído mais dez vezes) nas porções superior (anódica) e inferior (catódico). Em cada poço do gel, aplica-se $4 \mu 1$ de produto da PCR (no caso da deleção de 9pb) ou $10 \mu 1$ do produto da reação de restrição (no caso dos outro cinco marcadores), juntamente com $2 \mu$ de tampão de carregamento (loadding buffer - TBE 1x; Xilenocianol 0,25\%; Azul de Bromofenol 0,25\%; EDTA 0,1M pH 8,0; Ficoll 15\%). A cuba de eletroforese é conectada a uma fonte de eletroforese de alta voltagem e a separação eletroforética dos fragmentos é realizada durante 90 minutos a 150 volts, com amperagem liberada.

\subsection{Coloração e estocagem do gel}

Após o término da eletroforese a coloração do gel foi feita de acordo com protocolo adaptado (Sanguinetti et al. 1994). O gel deve ser colocado em recipiente contendo $100 \mathrm{ml}$ de solução fixadora $(166,7 \mathrm{ml}$ de etanol + 6,7 $\mathrm{ml}$ de ácido acético + água deionizada qsp. $1 \mathrm{~L})$ juntamente com 3,0 ml solução de nitrato de prata $(0,1 \mathrm{~g} / \mathrm{ml})$ à solução fixadora por 5 minutos em agitação. Em seguida, descarta-se tal solução e lava-se o gel em água deionizada agitando-se levemente por cerca de 10-15 segundos. Por fim, adiciona-se a solução reveladora $(2,25$ g de 
$\mathrm{NaOH}+1,5 \mathrm{ml}$ de formaldeído + água deionizada qsp. $100 \mathrm{ml}$ ), e agita-se levemente o recipiente até que as bandas apareçam nitidamente. Depois de revelado, deve-se descartar a solução reveladora e bloquear a reação adicionando-se $100 \mathrm{ml}$ de solução fixadora.

Após a leitura, o gel pode ser armazenado para posteriores análises e confirmações, submetendo-o a um simples processo de secagem. Estende-se uma folha de papel celofane bem umedecida sobre placa de vidro de área maior do que a do gel. Sobre o papel deve-se colocar o gel e sobre o gel coloca-se uma outra folha de papel celofane bem umedecida. Deve-se deixar o gel secando em temperatura ambiente por cerca de dois dias, antes de armazená-lo.

\subsection{Análises estatísticas}

\subsubsection{Freqüências alélicas}

A freqüência de cada haplogrupo de mtDNA encontrado foi estimada pelo método de contagem direta, de acordo com a equação:

$$
p_{i}=n_{i} / n
$$

onde $n_{i}$ é o número de ocorrências (freqüência absoluta) do haplogrupo $i$ na amostra e $n$ é o número total de indivíduos amostrados.

\subsubsection{Diversidade genética intra-populacional}

Definida como a probabilidade de que dois alelos amostrados aleatoriamente em uma dada população sejam diferentes, a diversidade genética intra-populacional $\left(h_{S k}\right)$ e sua variância 
amostral $\left[V\left(h_{S k}\right)\right]$ foram estimadas em cada população $k$, conforme as equações 8.5 e 8.12 (modificada) respectivamente, apresentadas em Nei (1987):

$$
\begin{gathered}
h_{S k}=\frac{n}{n-1}\left(1-\sum_{i=1}^{m} p_{i}^{2}\right) ; \\
V\left(h_{S k}\right)=\frac{2}{n(n-1)}\left\{2(n-2)\left[\sum_{i=1}^{m} p_{i}^{3}-\left(\sum_{i=1}^{m} p_{i}^{2}\right)^{2}\right]+\sum_{i=1}^{m} p_{i}^{2}-\left(\sum_{i=1}^{m} p_{i}^{2}\right)^{2}\right\},
\end{gathered}
$$

onde $n$ é o número de indivíduos analisados na população $k, p_{i}$ corresponde à freqüência do alelo $i$ na população $k$ e $m$ representa o número de alelos $i$ encontrados em tal população. Ambas as estimativas foram obtidas utilizando-se o programa Arlequin versão 2.000 (Schneider et al. 2000).

\subsubsection{Diversidade genética inter-populacional: $\boldsymbol{F}_{S T}$}

O parâmetro $F_{S T}\left(\theta_{W}\right)$ foi uma das ferramentas utilizadas para se estimar a diversidade genética entre duas ou mais populações. Os cálculos, feitos por meio do programa Arlequin versão 2.000 (Schneider et al. 2000), utilizando-se método baseado na correlação entre alelos (Weir e Cockerham 1984). Embora os resultados não sejam exatamente os mesmos, o $F_{S T}$ também pode ser definido em termos de probabilidades de identidade por descendência entre pares de alelos(Nei 1987):

$$
F_{S T}=\frac{J_{S}-J_{T}}{1-J_{T}},
$$

onde, considerando-se uma população total dividida em $k$ sub-populações $S$, sendo $p_{k i}$ a freqüência do alelo $i$ na sub-população $k$ e $p_{i}$ a freqüência do alelo $i$ na população total, 
temos $J_{S}=\frac{\sum_{k} J_{k}}{S}=\frac{\sum_{k}\left(\sum_{i} p_{k i}^{2}\right)}{S}$ correspondente à probabilidade média de que dois alelos amostrados ao acaso em uma mesma sub-população sejam idênticos por descendência e $J_{T}=\sum_{i} p_{i}^{2}$ à probabilidade de que dois alelos amostrados ao acaso na população total sejam idênticos por descendência (Nei 1987).

A distribuição nula de cada valor de $F_{S T}$ sob a hipótese de ausência de diferença entre as populações foi obtida permutando-se os haplogrupos entre as populações por 30 mil vezes (no caso de análises em escala continental, foram executadas 100 mil permutações). O valor de $p$ do teste corresponde à proporção das permutações que resultou em valores de $F_{S T}$ maiores ou iguais ao valor observado. Estimativa do erro padrão do valor de $p$ é feita pela partição do número total de passos da Cadeia de Markov em $B$ batches.

\subsubsection{Diversidade genética inter-populacional: $F_{S T}$ população-específico}

Visto que em sua forma convencional a análise de $F_{S T}$ tem por pressuposto oculto que a identidade gênica esperada e o tamanho efetivo populacional são iguais em todas as subpopulações consideradas, a violação de tais pressupostos, o que é de ocorrência constante na natureza, pode trazer viés às estimativas (Long e Kittles 2003). Portanto, o $F_{S T}$ definido no sub-ítem anterior equivale aproximadamente à média dos $F_{S T}$ população-específicos do conjunto de populações consideradas.

Sendo assim, valores de $F_{S T}$ população-específicos $\left(F_{S T(k)}\right)$ também foram estimados de acordo com a seguinte equação (Long e Kittles 2003):

$$
F_{S T(k)}=\frac{J_{k}-J_{T}}{1-J_{T}}
$$


onde $J_{k}=\sum_{i} p_{k i}^{2}$ corresponde à probabilidade de que dois alelos amostrados ao acaso em uma sub-população $k$ sejam idênticos por descendência. $O F_{S T(k)}$ pode ser claramente interpretado como um ganho de identidade gênica (ou perda de diversidade genética) na subpopulação $k$ em relação à população como um todo (Long e Kittles 2003).

\subsubsection{Teste exato de diferenciação populacional}

Esta análise testa a hipótese de distribuição aleatória de $k$ diferentes haplogrupos entre $r$ populações (Raymond e Rousset 1995). Tal teste é análogo ao Teste Exato de Fisher em tabelas de contingência $2 \times 2$, estendido para tabelas de contingência $r \times k$. Todos os potenciais estados desta tabela de contingência, mantendo os mesmos totais marginais, são explorados via Cadeia de Markov, sendo então estimada a probabilidade $(p)$ de se observar uma tabela menos ou igualmente provável do que a tabela original, sob hipótese de panmixia.

A fim de se assegurar que a Cadeia de Markov se iniciasse em posição aleatória, mil passos de desmemorização foram aplicados antes que os valores de $p$ passassem a serem computados. Uma estimativa do erro padrão do valor de $p$ é feita pela partição do número total de passos da Cadeia de Markov (30 mil) em B batches. O teste foi realizado utilizando-se o programa Arlequin versão 2.000 (Schneider et al. 2000).

\subsubsection{Análise de Variância Molecular (AMOVA)}

O programa Arlequin versão 2.000 (Schneider et al. 2000) foi novamente empregado na análise de variância molecular. Ao se alocar as diferentes populações em grupos, de acordo com os mais diversos critérios (lingüísticos, geográficos ou sociais), automaticamente se estabelece uma estrutura a ser testada. A análise hierárquica de variância leva à partição da 
variância total em componentes de covariância devido a diferenças entre indivíduos dentro de populações $\left(F_{S T}\right)$, entre populações de mesmo grupo $\left(F_{S C}\right)$ e entre grupos $\left(F_{C T}\right)$. O $F_{S T}$ pode é encarado como a correlação entre haplótipos aleatórios dentro de populações, em relação à correlação entre pares de haplótipos aleatoriamente amostrados na amostra total. $\mathrm{O} F_{C T}$ corresponde à correlação entre haplótipos aleatórios dentro de um grupo de populações, em relação à correlação entre pares de haplótipos aleatoriamente amostrados na amostra total. Por fim, o $F_{S C}$ equivale à correlação entre haplótipos aleatórios dentro de populações, em relação à correlação entre pares de haplótipos aleatoriamente amostrados dentro de um grupo de populações (Excoffier et al. 1992).

A distribuição nula de cada um dos valores de $F_{S T}, F_{S C}$ e $F_{C T}$ sob a hipótese de distribuição aleatória dos haplogrupos entre todas as populações foi obtida permutando-se, respectivamente, haplogrupos entre as populações entre grupos, haplogrupos entre as populações dentro de grupos e permutando-se populações entre grupos, por 30 mil vezes (no caso de análises em escala continental, foram executadas 100 mil permutações). O valor de $p$, corresponde, no caso $F_{S T}$, à proporção das permutações que resultou em valores de $F_{S T}$ menores ou iguais ao valor observado, e no caso de $F_{S C}$ e $F_{C T}$, à proporção das permutações que resultaram em valores de $F_{S C}$ e $F_{C T}$ maiores ou iguais aos valores observados. Estimativa do erro padrão de cada valor de $p$ é feita pela partição do número total de passos da Cadeia de Markov em $B$ batches.

Note que este valor de $F_{S T}$ corresponde a uma estimativa de variância intra-populacional, não sendo equivalente, portanto, ao $F_{S T}$ tradicionalmente utilizado (Weir e Cockerham 1984; Nei 1987). Apenas as notações coincidem. Por outro lado, no caso de estrutura hierárquica simples (ausência de estrutura hierárquica) de indivíduos haplóides, na qual todas as populações pertencem a um único grupo, o componente da variância que 
quantifica a diferença entre populações de mesmo grupo $\left(F_{S C}\right)$ é absolutamente idêntico ao valor de $F_{S T}\left(\theta_{W}\right)$ proposto por Weir e Cockerham (1984).

\subsubsection{Distogramas}

Os distogramas correspondem a gráficos nos quais a distância genética $\left(F_{S T}\right)$ média entre todos os pares de populações que pertencem a uma determinada classe de distâncias espaciais $\left(s_{q}\right)$ são plotadas em função das classes de distâncias (Degen et al. 2001), incorporando características espaciais à análise convencional de $F_{S T}$.

A partir das coordenadas geográficas de cada população amostrada, as distâncias aproximadas entre cada par de populações são calculadas, formando-se uma matriz de distâncias geográficas. Tendo definido o número de classes de distâncias $\left(s_{q}\right)$ a serem empregadas e suas amplitudes (que é igual em todas as classes), todos os pares de populações que compõem a matriz se enquadrarão em alguma das classes, e serão então utilizadas para o cálculo de distância genética $\left(F_{S T}\right)$ associada a tal classe. Para este cálculo de $F_{S T}$, temos:

- entre as populações $k$ e $l: \quad J_{k}=\sum_{i} p_{k i}^{2}, J_{l}=\sum_{i} p_{l i}^{2}, J_{S k l}=\frac{J_{k}+J_{l}}{2}$ e $J_{T k l}=\sum_{i} p_{k i} \cdot p_{l i}$.

- para cada classe de distâncias $q: \quad J_{S q}=\bar{J}_{S k l}, \quad J_{T q}=\bar{J}_{T k l}$ e $F_{S T q}=\frac{J_{S q}-J_{T q}}{1-J_{T q}}$, onde $\bar{J}_{S k l}$ e $\bar{J}_{T k l}$ são respectivamente as médias de todos os $J_{S k l}$ e $J_{T k l}$ correspondentes à classe de distâncias $q$. 
Por fim, após todos os valores de $F_{S T q}$ de cada classe de distâncias terem sido calculados, um único valor referencial de $F_{S T}$, englobando todas as populações consideradas na análise, é estabelecido: $J_{S}=\frac{\sum_{k} J_{k}}{S}, J_{T}=\frac{\sum_{k \neq l} \sum_{i} p_{k i} \cdot p_{l 1}}{S(S-1)}$ e $F_{S T}=\frac{J_{S}-J_{T}}{1-J_{T}}$.

Para simplicidade computacional, o presente cálculo de $F_{S T}$ não leva em consideração os tamanhos amostrais, não sendo aplicado, portanto, qualquer correção para pequenas amostras. Entretanto, o viés resultante é mínimo, exceto quando amostras com tamanhos amostrais inferiores a dez indivíduos são consideradas. Intervalos de confiança de 95\% e 99\% foram obtidos para o valor de $F_{S T}$ de cada classe de distâncias, por meio de 2 mil permutações via simulações de Monte-Carlo (Manly 1997). Cada permutação consiste na redistribuição aleatória dos dados genéticos sobre as coordenadas geográficas das localidades amostradas. A hipótese nula é de distribuição espacial aleatória de cada medida de distância genética. Os distogramas foram obtidos utilizando-se o programa Spatial Genetic Software (SGS) versão 1.0c (Degen et al. 2001).

\subsection{8 Índice de autocorrelação espacial para análise de DNA}

A autocorrelação espacial consiste em uma ferramenta que vem sendo usada para inferências sobre os fatores microevolutivos (mutação, seleção, migração e isolamento-por-distância) que estão por trás dos padrões observados de variação espacial das freqüências alélicas (Sokal et al. 1989). O índice aqui utilizado, também conhecido como AIDA (do inglês, autocorrelation index for DNA analysis) deriva da análise de autocorrelação espacial clássica (Sokal e Oden 1978), sendo uma variação desenvolvida especialmente para a análise de RFLPs ou seqüências de DNA haplóide ou livre de recombinação (Bertorelle e Barbujani 1995). A vantagem deste tratamento multi-alélico em relação à forma de análise clássica se baseia no 
fato de que os alelos constituem réplicas de um mesmo processo evolutivo, sendo que as diferenças em suas distribuições são encaradas como conseqüências estocásticas da deriva genética. A informação de todos os alelos é extraída simultaneamente de modo que o padrão de afinidade genética torna-se mais claro e as distorções estocásticas são minimizadas (Smouse e Peakall 1999).

Análogo ao $I$ definido por Moran (Moran 1950), o II deve medir se seqüências individuais (haplogrupos) se assemelham a outras amostradas em diferentes localidades, e em que extensão esta correlação ocorre.

Para tanto, cada haplótipo (haplogrupo) é convertido na forma de um vetor binário $\mathrm{p}$ $\left(\mathrm{p}=\left[p_{1}, p_{2}, p_{3}, \ldots, p_{s}\right]\right)$, onde $p_{k}$ representa a presença ou ausência de sítio de restrição em cada um dos $S$ RFLPs analisados, assumindo os valores de 0 (quando o alelo for comum em todos os haplogrupos) ou 1 (quando o alelo caracterizar o haplogrupo). Em seguida, uma matriz de distâncias geográficas em arco (que leva em consideração a curvatura do globo terrestre, conhecidas como great circle distances) entre pares de indivíduos é obtida a partir das coordenadas geográficas de cada um deles. Defini-se então o número de classes de distâncias a serem empregadas e suas amplitudes. Para cada uma das classes um AIDA é calculado de acordo com a seguinte equação (Bertorelle e Barbujani 1995):

$$
I I=\frac{n \sum_{i=1}^{n-1} \sum_{j>i}^{n} w_{i j} \sum_{k=1}^{S}\left(p_{i k}-\bar{p}_{k}\right)\left(p_{j k}-\bar{p}_{k}\right)}{W \sum_{i=1}^{n} \sum_{k=1}^{S}\left(p_{i k}-\bar{p}_{k}\right)^{2}},
$$

onde $n$ corresponde ao tamanho amostral, $p_{i k}$ e $p_{j k}$ correspondem ao valor atribuído ao sítio $k$ dos indivíduos $i$ e $j$ ( 0 ou 1 , de acordo com o vetor binário previamente definido), $p_{k}$ corresponde ao valor médio $\left(0<p_{k}<1\right)$ de todos os vetores incluídos na análise com relação ao RFLP $k$ (nas presentes análises, $p_{k}$ coincide exatamente com a freqüência total do alelo que 
caracteriza o haplogrupo definido pelo RFLP $k$ ) e $w_{i j}$ assume valores de 0 (se a distância que separa os indivíduos $i$ e $j$ não se enquadrar na classe distância para qual o AIDA esta sendo calculado) ou 1 (se a distância que separa os indivíduos $i$ e $j$ se enquadrar no intervalo da classe de distâncias para qual o AIDA está sendo calculado). A somatória é entre todos os $S$ sítios e $n$ indivíduos da amostra.

O índice $I I$ compartilha as mesmas propriedades estatísticas do $I$ de Moran, sendo os valores distribuídos no intervalo entre -1 e 1 . Sob a hipótese nula de distribuição espacial aleatória dos haplótipos, os valores esperados para cada índice são obtidos pela equação:

$$
E(I I)=E(I)=-1 /(n-1)
$$

Para se testar a significância do AIDA relativo a uma determinada classe de distâncias, intervalos de confiança de $95 \%$ e $99 \%$ são obtidos a partir da distribuição nula de II. Para tanto, procedimento de alocação aleatória de todos os indivíduos no espaço geográfico, respeitando para cada localidade o tamanho amostral observado, é executado 10 mil vezes, e um novo AIDA é recalculado em cada uma delas. Tal procedimento é repetido independentemente para o cálculo de intervalos de confiança das demais classe de distâncias. Todos os cálculos acima mencionados foram executados através do programa AIDA_FRQ, contido no pacote computacional AIDA (Bertorelle e Barbujani 1995).

Os correlogramas, isto é, gráficos nos quais o índice $I I$ de cada classe de distâncias espacial é plotado em função das classes de distâncias, proporcionando uma visão simples do padrão de variação espacial, foram desenhados manualmente. Para se testar a significância do correlograma como um todo em relação à distribuição espacial aleatória, foi empregado o critério de Bonferroni (Oden 1984). Para o correlograma como um todo ser considerado significativo a um dado $\alpha$, pelo menos uma das classes do correlograma deve se apresentar 
significativa ao nível $\alpha / q$, onde $q$ corresponde ao número de classes de distâncias do correlograma. Portanto, a probabilidade de erro tipo I (isto é, rejeitar-se erroneamente a hipótese nula de distribuição espacial aleatória dos haplótipos) de um correlograma é dado por $k\left(\alpha_{I I}\right)$, onde $\alpha_{I I}$ é o menor valor de probabilidade nos índices do correlograma (Diniz-Filho 1998).

\subsubsection{Distâncias genéticas e representações gráficas}

A distância de Reynolds, Weir e Cockerham (1983), baseada em coancestralidade $\left(F_{S T}\right)$, assume a não ocorrência de mutações e que toda alteração nas freqüências alélicas decorrem exclusivamente da deriva genética (Felsenstein 1989). Mesmo havendo algumas discrepâncias dos presentes dados com relação às premissas envolvendo a distância de Reynolds, Weir e Cockerham (1983), como a existência de fluxo gênico entre as aldeias após a separação (o que não é previsto em nenhum dos modelos de distância), esta parece ser a medida de distância mais adequada para ser utilizada neste trabalho, uma vez que as populações estão altamente susceptíveis aos efeitos da deriva genética.

Tal distância estima uma quantia proporcional ao período decorrido desde a separação das populações, tempo necessário para originar o nível de variância entre as freqüências alélicas das populações $k$ e $l$ comparadas (Meyer 1995), podendo ser calculada pela seguinte expressão (Felsenstein 1989):

$$
D_{R}^{2}=\frac{\sum_{m} \sum_{i}\left(p_{k m i}-p_{l m i}\right)^{2}}{2 \sum_{m}\left(1-\sum_{i} p_{k m i} p_{l m i}\right)},
$$

onde $p_{k m i}$ e $p_{l m i}$ correspondem às freqüências do alelo $i$ do locus $m$ nas populações $k$ e $l$, respectivamente. 
Os cálculos de distâncias genéticas entre pares de populações (Reynolds et al. 1983) foram feitos utilizando-se o programa Gendist que faz parte do pacote PHYLIP versão 3.62 (Felsenstein 1989). As matrizes de distâncias genéticas foram então representadas graficamente pela análise multidimensional (MDS, do inglês, multidimensional scaling) (Kruskal 1964; Kruskal e Wish 1978). A análise de MDS (métrica ou não-métrica) permite transformar uma matriz de dissimilaridade em distâncias representadas em um espaço multidimensional. Os gráficos de MDS foram obtidos utilizando-se as matrizes de distância como entrada de dados para o programa ALSCAL, contido no pacote SPSS 11.0.0 (SPSS Inc., 2001). Na análise multidimensional foram testadas soluções métricas (Kruskal e Wish 1978) e não-métricas (Kruskal 1964), variando de uma a seis dimensões e foram analisados os índices de performance de cada uma delas: stress (medida específica que indica o quanto os dados desviam do modelo) e $r^{2}$ (coeficiente de correlação ao quadrado, isto é, proporção da variância dos dados explicada pela solução) decorrente de cada uma delas. A solução escolhida foi sempre aquela que apresentou incremento de $r^{2}$ e decréscimo de stress representativos em relação à solução imediatamente anterior com uma dimensão a menos. Para evidenciar a escolha da melhor solução para cada análise, os valores de stress e $r^{2}$ foram plotados em função do número de dimensões (solução).

\subsubsection{Mapa geográfico de freqüências alélicas}

Os mapas geográficos de freqüências alélicas transmitem informações imediatas sobre a localização, na superfície de freqüências alélicas, de freqüências máxima, mínima e até mesmo de gradientes (clinas) em determinado espaço geográfico. A não ser que números exatos sejam imprescindíveis, uma figura equivale a milhares de números (Cavalli-Sforza et al. 1994). 
Para esta análise de interpolação de freqüências alélicas foi empregado o programa SurGe versão 5.50. O algoritmo, denominado ABOS (do inglês, Approximation Based On Smoothing), permite tanto a interpolação exata como o smoothing das freqüências, pelo simples ajuste de parâmetros. A qualidade das superfícies resultante é comparável à de superfícies criadas pelos algoritmos Kriging ou Minimum curvature.

Inicialmente, é necessário o delineamento das fronteiras continentais. As Américas foram então divididas em América do Norte e América do Sul, sendo que a divisão ocorreu aproximadamente na metade de Honduras e El Salvador. Foram obtidas coordenadas geográficas de 423 e 356 pontos que permitem definir com relativa precisão o contorno das América do Norte (80 deles destinados à delimitação da Groenlândia, Cuba, Porto Rico e outras seis ilhas do Pacífico Norte) e do Sul (13 deles destinados à delimitação de Aruba e República Dominicana), respectivamente. Para cada análise, são fornecidas as coordenadas $x-y-z$ de cada localidade amostrada, sendo que $x$ e $y$ representam a longitude e a latitude, respectivamente, enquanto que $\mathrm{z}$ representa o valor da variável mensurada. Em um primeiro conjunto de análises, as freqüências de cada um dos haplogrupos, separadamente, assumiram o valor de $z$. Este procedimento foi realizado para a visualização do padrão de distribuição espacial de cada um dos quatro haplogrupos. Em outro conjunto de análises, foram atribuídos (separadamente) a $z$ os valores de cada uma das dimensões obtidas pela análise de MDS, resultando em mapas semelhante aos mapas sintéticos (Menozzi et al. 1978), os quais permitem visualizar migrações antigas e outros fenômenos que afetam todos ou vários genes (Cavalli-Sforza et al. 1994). Embora para este segundo conjunto de análises apenas quatro alelos de um único locus tenham sido utilizados, o que pode permitir que tendências geográficas devido à introdução de autocorrelação espacial espúria (artificial) sejam detectadas em dados espacialmente aleatórios (Sokal et al. 1999), inferências históricas a 
partir deles serão obtidas apenas quando corroboradas por outras análises e evidências externas, como sugerido na literatura (Rendine et al. 1999; Sokal et al. 1999).

A interpolação faz com que a superfície resultante se ajuste exatamente aos pontos amostrados. Já o smoothing faz com que a superfície resultante se ajuste de maneira mais livre sobre os pontos amostrados, minimizando a ocorrência de picos e vales decorrentes de vieses causados por variância amostral (principalmente em localidades com tamanhos amostrais reduzidos) e pelo fato de algumas populações constituírem verdadeiros outliers (CavalliSforza et al. 1994). Smoothing é portanto a melhor opção para a construção dos mapas (Cavalli-Sforza et al. 1994). Os parâmetros da análise foram ajustados de maneira a permitir que a superfície resultante se ajuste mais livremente sobre as localidades amostradas.

\subsubsection{Outras análises}

Os já tradicionais testes estatísticos não-paramétricas aqui empregados, o teste $U$ de Wilcoxon-Mann-Whitney $\left(U_{W M W}\right)$ e o coeficiente de correlação para postos de Spearman $\left(r_{S}\right)$ (Callegari-Jacques 2003), foram executados utilizando-se o programa BioEstat 2.0 (Ayres et al. 2000).

Para se calcular as distâncias geográficas entre os 120 pares formados pelas 16 aldeias aqui estudadas, foi utilizado o aplicativo Calculator for Distances between Geographical Locations (Bogan 1998). A partir das coordenadas geográficas (latitude e longitude) de pares de localidades, distâncias em arco (Great circle distances), baseadas na curvatura do globo terrestre, são expressas em quilômetros, levando ainda em consideração o achatamento do globo terrestre e o raio de 6.378,14 quilômetros ao longo da Linha do Equador. 


\section{Resultados}

Todos os quatro haplogrupos de DNA mitocondrial previamente encontrados e característico de populações indígenas sul-americanas autóctones foram encontrados na presente amostra (Tabela 2). $O$ haplogrupo $X$, encontrado entre os indígenas norte-americanos, não foi observado. Nenhum haplogrupo de origem européia foi encontrado e apenas um indivíduo, da aldeia Morada Nova (Katukina), apresentou haplótipo pertencente ao haplogrupo L, característico de populações africanas. Tal indivíduo foi excluído de todas as análises realizadas neste trabalho.

\subsection{Diversidade intra-populacional}

Já desconsiderando o indivíduo com a presença do sítio de restrição +3592 HpaI (haplogrupo L), foi observado de dois a quatro haplogrupos em cada aldeia, sendo que os haplogrupos A e C, os mais freqüentes, não foram encontrados em apenas uma aldeia (Vida Nova e Sete Estrelas, respectivamente). O haplogrupo B foi o menos freqüente e se restringiu a apenas dez aldeias (Tabela 2). Com relação ao agrupamento de aldeias em tribos, foi observado de três a quatro haplogrupos em cada uma delas, sendo que apenas o $\mathrm{C}$ esteve presente em todas.

A diversidade intra-populacional variou de 0,3626 na aldeia Sete Estrelas até 0,7667 na aldeia Três Unidos (Tabela 2). Quando é feito o agrupamento de aldeias em tribos, a amplitude de variação é reduzida, variando de 0,5619 nos Yaminawa aos mesmos 0,7667 em Kanamarí (Tabela 2). De modo geral, observa-se que as aldeias do grupo lingüístico Pano apresentam menor número médio de haplogrupos do que as aldeias Tikúna $(2,83$ e 3,63, respectivamente), bem como menor diversidade intra-populacional média $(0,5782$ e 0,6695 , 
respectivamente). Entretanto, tanto o número de haplogrupos quanto a diversidade genética encontrados no conjunto de aldeias Tikúna, não diferem significantemente do observado no conjunto de aldeias Pano, como pode ser visto pelo teste não-paramétrico de Wilcoxon-Mann-Whitney (em ambos os casos: $U_{W M W}=10,00 ; p=0,0707$ ).

Com relação aos Tikúna, tais valores médios das aldeias são extremamente semelhantes ao da tribo analisada como um todo (4 haplogrupos gerando diversidade de 0,6981). Por outro lado, no que diz respeito às aldeias Pano, os valores médios das aldeias são bem inferiores ao do grupo analisado de forma global (4 haplogrupos gerando diversidade de $0,6944)$.

\subsection{Diversidade inter-populacional}

Dois métodos distintos que possuem a mesma finalidade de quantificar o grau de diferenciação entre pares ou conjuntos de populações associados à significância estatística, isto é, a probabilidade de se obter pares ou conjuntos de amostras mais heterogêneos do que aquele em questão, foram empregados: $F_{S T}$ e teste exato de diferenciação populacional. Embora as informações destas análises sejam de certa forma redundantes, a intenção foi justamente de proporcionar conclusões mais robustas possíveis, uma vez que um método de análise pode ser mais sensível ou conservativo do que outros.

Assumindo-se determinado nível de significância (5\% ou 1\%), todas as comparações envolvendo mais de duas populações consideradas significantes em tal nível por um método também se mostraram significantes no mesmo nível pelo outro método (Tabela 3). 
Tabela 2 - Freqüências absolutas dos haplogrupos de DNA mitocondrial encontrados e diversidade genética intra-populacional em cada aldeia/tribo estudada.

\begin{tabular}{|c|c|c|c|c|c|c|c|c|}
\hline \multirow{2}{*}{ Aldeia } & \multirow{2}{*}{ Tribo } & \multirow{2}{*}{$n^{l}$} & \multicolumn{5}{|c|}{ Haplogrupos } & \multirow{2}{*}{$h_{S k}{ }^{2}$} \\
\hline & & & $A$ & $B$ & $\bar{C}$ & $\bar{D}$ & $L$ & \\
\hline Jandu Cachoeira & Baníwa & 23 & 12 & 7 & 4 & & & $0,6324 \pm 0,0645$ \\
\hline Três Unidos & Kanamari & 21 & 7 & 5 & 6 & 3 & & $0,7667 \pm 0,0407$ \\
\hline Belém & Tikúna & 26 & 5 & & 5 & 16 & & $0,5692 \pm 0,0838$ \\
\hline Bom Jardim & Tikúna & 18 & 3 & 2 & 10 & 3 & & $0,6601 \pm 0,0998$ \\
\hline Campo Alegre & Tikúna & 23 & 5 & 1 & 9 & 8 & & $0,7075 \pm 0,0466$ \\
\hline Feijoal & Tikúna & 25 & 12 & 2 & 9 & 2 & & $0,6533 \pm 0,0611$ \\
\hline Marajá & Tikúna & 22 & 7 & 3 & 6 & 6 & & $0,7662 \pm 0,0374$ \\
\hline Nova Itália & Tikúna & 26 & 5 & 3 & 9 & 9 & & $0,7385 \pm 0,0418$ \\
\hline Umariaçu & Tikúna & 24 & 4 & & 11 & 9 & & $0,6486 \pm 0,0501$ \\
\hline Vendaval & Tikúna & 23 & 5 & & 5 & 13 & & $0,6126 \pm 0,0768$ \\
\hline Morada Nova & Katukina & 11 & 1 & & 5 & 4 & 1 & $0,6444 \pm 0,1012$ \\
\hline Sete Estrelas & Katukina & 14 & 11 & 3 & & & & $0,3626 \pm 0,1302$ \\
\hline Cana Brava & Kaxináwa & 12 & 4 & 1 & 6 & 1 & & $0,6818 \pm 0,1019$ \\
\hline Paredão & Kaxináwa & 7 & 4 & & 3 & & & $0,5714 \pm 0,1195$ \\
\hline Vida Nova & Marúbo & 18 & & 3 & 9 & 6 & & $0,6471 \pm 0,0691$ \\
\hline \multirow[t]{9}{*}{ - } & Yaminawa & 15 & 9 & & 5 & 1 & & $0,5619 \pm 0,0954$ \\
\hline & Baníwa & 23 & 12 & 7 & 4 & & & $0,6324 \pm 0,0645$ \\
\hline & Kanamari & 21 & 7 & 5 & 6 & 3 & & $0,7667 \pm 0,0407$ \\
\hline & Tikúna & 187 & 46 & 11 & 64 & 66 & & $0,6981 \pm 0,0116$ \\
\hline & Katukina & 25 & 12 & 3 & 5 & 4 & 1 & $0,6920 \pm 0,0717$ \\
\hline & Kaxináwa & 19 & 8 & 1 & 9 & 1 & & $0,6257 \pm 0,0669$ \\
\hline & Marúbo & 18 & & 3 & 9 & 6 & & $0,6471 \pm 0,0691$ \\
\hline & Yaminawa & 15 & 9 & & 5 & 1 & & $0,5619 \pm 0,0954$ \\
\hline & Pano & 77 & 29 & 7 & 28 & 12 & 1 & $0,6944 \pm 0,0257$ \\
\hline Total & & 308 & 94 & 30 & 102 & 81 & 1 & $0,7190 \pm 0,0079$ \\
\hline
\end{tabular}

$n=$ número de indivíduos analisados;

${ }^{2} \mathrm{O}$ cálculo de $h_{S k}$, considera apenas as freqüências dos haplogrupos A, B, C e D.

Já entre pares de populações (Tabelas 4 e 5), das 120 comparações, houve 15 (12,5\%) discordâncias. Destas 15, 8 foram significantes a 5\% de acordo com o teste exato de diferenciação populacional enquanto foram não-significantes de acordo com o $F_{S T} ; 5$ foram 
significantes a $1 \%$ de acordo com o teste exato enquanto que foram significantes apenas a $5 \%$ de acordo com o $F_{S T}$; e as 2 restantes foram significantes apenas de acordo com o $F_{S T}$. Aprofundando nesta questão, $62(51,67 \%)$ e $53(44,17 \%)$ das 120 comparações apresentaram respectivamente menor e maior probabilidade pelo teste exato do que de acordo com o $F_{S T}$; valores de probabilidade idênticos entre os dois métodos foram obtidos em cinco $(4,17 \%)$ das comparações (Tabela 5). Isto nos leva a concluir que, para este conjunto de dados, o $F_{S T}$ representa uma ferramenta estatística levemente mais conservativa (ou menos sensível) do que o teste exato. Entretanto, visto que a quantidade de discrepâncias foi muito pequena, as conclusões gerais obtidas não se alteram independente do método de análise escolhido.

Tabela $3-F_{S T}$ e teste exato de diferenciação populacional, baseados nas freqüências dos haplogrupos de mtDNA, em diversos conjuntos de amostras formados pelo agrupamento das aldeias analisadas no presente trabalho. Os valores de significantes aos níveis de $1 \%$ estão destacados em negrito.

\begin{tabular}{|c|c|c|}
\hline Conjunto de amostras & $\overline{F_{S T}(\text { probabilidade) }}$ & $\begin{array}{c}\text { Probabilidade do teste exato de } \\
\text { diferenciação populacional }\end{array}$ \\
\hline 8 aldeias Tikúna & $0,0481(0,0058 \pm 0,0004)$ & $0,0059 \pm 0,0029$ \\
\hline 2 aldeias Katukina & $0,4690(0,0001 \pm 0,0000)$ & $0,0000 \pm 0,0000$ \\
\hline 2 aldeias Kaxináwa & $-0,0573(0,6754 \pm 0,0027)$ & $0,8568 \pm 0,0034$ \\
\hline 6 aldeias Pano & $0,1985(0,0000 \pm 0,0000)$ & $0,0000 \pm 0,0000$ \\
\hline todas 16 aldeias & $0,1018(0,0000 \pm 0,0000)$ & $0,0000 \pm 0,0000$ \\
\hline todas 7 tribos & $0,0786(0,0000 \pm 0,0000)$ & $\mathbf{0 , 0 0 0 0} \pm \mathbf{0 , 0 0 0 0}$ \\
\hline
\end{tabular}

Pode-se notar que existe grande diversidade entre as 16 aldeias (Tabela 3). Embora ambos tenham sido altamente significantes, o $F_{S T}$ entre as oito aldeias Tikúna $\left(F_{S T}=0,0481\right)$ foi bastante inferior ao observado entre as seis aldeias Pano $\left(F_{S T}=0,1985\right)$. Diante deste achado de grande heterogeneidade intra-tribal nos Pano e de heterogeneidade também significante entre as aldeias Tikúna, torna-se necessário identificar se as aldeias envolvidas em cada um destes dois cálculos são igualmente diferentes umas das outras, ou se dentro do 
grupo existem um conjunto de aldeias homogêneas juntamente com uma ou duas que constituem verdadeiras exceções. Para identificar estas possíveis aldeias destoantes (outliers), foi empregado o cálculo de $F_{S T}$ população-específicos (Tabela 6).

Dentre os Tikúna, os valores de $F_{S T(k)}$ variaram de -0,0534 (Marajá) até 0,2117 (Belém). Além de Belém, a aldeia Vendaval $\left(F_{S T(k)}=0,1560\right)$ se mostrou bem mais divergente do que as demais (Tabela 6). Ao se estimar $F_{S T}$ novamente, excluindo-se a aldeia Belém, obtém-se valor significante apenas ao nível de 5\% $\left(F_{S T}=0,0322 ; p=0,0397\right)$. Se além da aldeia Belém for excluída também a aldeia Vendaval, obtém-se $F_{S T}$ bastante reduzido e não-significante $\left(F_{S T}=0,0156 ; p=0,1754\right)$. Ao observar as freqüências dos haplogrupos nestas duas aldeias (Tabela 2), observa-se que elas apresentam perfil genético quase idêntico: haplogrupo $\mathrm{D}$ em freqüências muito elevadas, haplogrupo $\mathrm{C}$ em freqüências menores do que nas demais aldeias e ausência do haplogrupo B. Tanto $F_{S T}$ quanto teste exato de diferenciação populacional baseados em pares de aldeias (Tabelas 4 e 5) indicam forte homogeneidade entre as aldeias Belém e Vendaval $(p=1,0000)$.

Dentre os Pano, os valores de $F_{S T(k)}$ (Tabela 6) foram bem superiores, variando de 0,0879 (Cana Brava - Kaxináwa) até o valor máximo de 0,5086 (Sete Estrelas - Katukina). Para que o valor $F_{S T}$ nos Pano como um todo deixe de ser significativo aos níveis de $1 \%$ e $5 \%$, é preciso excluir, respectivamente, apenas a aldeia Sete Estrelas $\left(F_{S T}=0,1026\right.$; $p=0,0137)$ e as três aldeias mais divergentes Sete Estrelas, Paredão e Yaminawa $\left(F_{S T}=0,0195 ; p=0,2743\right)$. 
Tabela 4 - Matriz de valores de $F_{S T}$ obtidos a partir das freqüências dos haplogrupos de mtDNA (abaixo da diagonal) e de distâncias geográficas em quilômetros (acima da diagonal) entre as 16 aldeias analisadas no presente estudo. As letras iniciais dos nomes das aldeias foram utilizadas para identificá-las. Os valores de $F_{S T}$ significantes aos níveis de $5 \%$ e $1 \%$ estão destacados em itálico e negrito, respectivamente.

\begin{tabular}{|c|c|c|c|c|c|c|c|c|c|c|c|c|c|c|c|c|}
\hline & $J C$ & $T U$ & $B$ & $B J$ & $C A$ & $F$ & $M$ & $N I$ & $U$ & $V$ & $M N$ & $S E$ & $C B$ & $P$ & $V N$ & $Y$ \\
\hline $\mathrm{JC}$ & 0 & 907,41 & 612,41 & 675,82 & 554,94 & 648,27 & 659,37 & 575,41 & 658,31 & 564,06 & 1087,53 & 1131,93 & 1083,29 & 1083,29 & 995,90 & 1131,93 \\
\hline TU & 0,0067 & 0 & 298,72 & 249,93 & 353,98 & 261,77 & 253,17 & 367,05 & 261,50 & 344,77 & 192,05 & 290,43 & 87,08 & 87,08 & 288,06 & 290,43 \\
\hline B & 0,3072 & 0,1609 & 0 & 73,29 & 58,31 & 37,04 & 46,99 & 169,89 & 52,47 & 49,65 & 475,13 & 528,92 & 470,88 & 470,88 & 422,23 & 528,92 \\
\hline BJ & 0,1748 & 0,0292 & 0,1927 & 0 & 129,10 & 54,98 & 39,93 & 232,20 & 20,89 & 121,30 & 414,19 & 459,34 & 410,23 & 410,23 & 348,94 & 459,34 \\
\hline $\mathrm{CA}$ & 0,1681 & 0,0248 & 0,0465 & $-0,0008$ & 0 & 93,33 & 105,10 & 149,79 & 108,95 & 9,21 & 532,84 & 586,98 & 528,53 & 528,53 & 476,55 & 586,98 \\
\hline $\mathrm{Fl}$ & 0,0297 & $-0,0041$ & 0,2258 & 0,0590 & 0,0597 & 0 & 15,89 & 177,30 & 37,19 & 84,25 & 439,55 & 497,08 & 435,23 & 435,23 & 397,88 & 497,08 \\
\hline M & 0,0617 & $-0,0294$ & 0,0725 & 0,0285 & $-0,0187$ & 0,0097 & 0 & 192,87 & 24,68 & 96,24 & 428,16 & 483,17 & 423,91 & 423,91 & 382,21 & 483,17 \\
\hline NI & 0,1469 & 0,0101 & 0,0433 & 0,0072 & $-0,0369$ & 0,0672 & $-0,0245$ & 0 & 213,06 & 148,70 & 558,97 & 642,00 & 554,04 & 554,04 & 566,45 & 642,00 \\
\hline $\mathrm{U}$ & 0,2314 & 0,0697 & 0,0622 & 0,0013 & $-0,0367$ & 0,1021 & 0,0175 & $-0,0208$ & 0 & 100,94 & 430,28 & 478,53 & 426,22 & 426,22 & 369,79 & 478,53 \\
\hline V & 0,2666 & 0,1220 & $-0,0393$ & 0,1511 & 0,0164 & 0,1800 & 0,0393 & 0,0165 & 0,0330 & 0 & 523,79 & 578,54 & 519,47 & 519,47 & 469,38 & 578,54 \\
\hline $\mathrm{MN}$ & 0,2595 & 0,0735 & 0,0546 & $-0,0215$ & $-0,0524$ & 0,1225 & 0,0188 & $-0,0366$ & $-0,0702$ & 0,0249 & 0 & 134,87 & 5,20 & 5,20 & 248,17 & 134,87 \\
\hline SE & 0,0422 & 0,1620 & 0,4322 & 0,3842 & 0,3257 & 0,1444 & 0,1979 & 0,3047 & 0,3970 & 0,3940 & 0,4690 & 0 & 138,96 & 138,96 & 177,28 & 0,00 \\
\hline $\mathrm{CB}$ & 0,0816 & $-0,0159$ & 0,2152 & $-0,0423$ & 0,0058 & $-0,0316$ & $-0,0030$ & 0,0176 & 0,0288 & 0,1653 & 0,0290 & 0,2821 & 0 & 0,00 & 248,91 & 138,96 \\
\hline $\mathrm{P}$ & 0,0347 & 0,0115 & 0,2942 & 0,0685 & 0,0833 & $-0,0766$ & 0,0304 & 0,0993 & 0,1297 & 0,2379 & 0,1620 & 0,1765 & $-0,0573$ & 0 & 248,91 & 138,96 \\
\hline $\mathrm{VN}$ & 0,2585 & 0,0807 & 0,1319 & $-0,0084$ & 0,0051 & 0,1663 & 0,0566 & $-0,0018$ & $-0,0031$ & 0,1045 & $-0,0472$ & 0,4660 & 0,0630 & 0,2162 & 0 & 177,28 \\
\hline Y & 0,0487 & 0,0407 & 0,2740 & 0,1301 & 0,1089 & $-0,0372$ & 0,0469 & 0,1216 & 0,1584 & 0,2244 & 0,1961 & 0,1238 & 0,0112 & $-0,1014$ & 0,2530 & 0 \\
\hline
\end{tabular}


Tabela 5 - Matriz de probabilidades relacionadas aos valores de $F_{S T}$ apresentados na Tabela 4 (abaixo da diagonal) e probabilidades de não-diferenciação obtidas em teste exato de diferenciação populacional baseado nas freqüências dos haplogrupos de mtDNA (acima da diagonal) entre as 16 aldeias analisadas no presente estudo. As letras iniciais dos nomes das aldeias foram utilizadas para identificá-las no cabeçalho. Os valores significantes aos níveis de 5\% e $1 \%$ estão destacados em itálico e negrito, respectivamente.

\begin{tabular}{|c|c|c|c|c|c|c|c|c|c|c|c|c|c|c|c|c|}
\hline & $J C$ & $T U$ & $B$ & $B J$ & $C A$ & $F$ & $M$ & $N I$ & $U$ & $V$ & $M N$ & $S E$ & $C B$ & $P$ & $V N$ & $Y$ \\
\hline Jandu Cachoeira & & 0,2142 & 0,0000 & 0,0039 & 0,0003 & 0,0909 & 0,0278 & 0,0020 & 0,0000 & 0,0000 & 0,0004 & 0,1951 & 0,0726 & 0,1963 & 0,0000 & 0,0362 \\
\hline Três Unidos & 0,3046 & - & 0,0011 & 0,3398 & 0,1432 & 0,4299 & 0,7226 & 0,2817 & 0,0159 & 0,0061 & 0,1001 & 0,0175 & 0,5795 & 0,3836 & 0,0275 & 0,1457 \\
\hline Belém & 0,0000 & 0,0027 & - & 0,0047 & 0,1769 & 0,0003 & 0,0485 & 0,1135 & 0,1190 & 1,0000 & 0,1973 & 0,0000 & 0,0044 & 0,0068 & 0,0042 & 0,0023 \\
\hline Bom Jardim & 0,0043 & 0,1954 & 0,0033 & - & 0,4931 & 0,1883 & 0,3461 & 0,4776 & 0,2526 & 0,0170 & 0,5758 & 0,0002 & 0,8431 & 0,2453 & 0,2779 & 0,0458 \\
\hline Campo Alegre & 0,0016 & 0,2112 & 0,1180 & 0,3732 & - & 0,0711 & 0,5790 & 0,8995 & 0,8920 & 0,3046 & 0,8368 & 0,0000 & 0,3684 & 0,1530 & 0,1200 & 0,0520 \\
\hline Feijoal & 0,1701 & 0,4284 & 0,0001 & 0,0780 & 0,0770 & - & 0,3109 & 0,0526 & 0,0083 & 0,0026 & 0,0395 & 0,0174 & 0,8763 & 1,0000 & 0,0003 & 0,8434 \\
\hline Marajá & 0,0677 & 0,7749 & 0,0526 & 0,1987 & 0,6392 & 0,2841 & - & 0,7727 & 0,1386 & 0,1227 & 0,3085 & 0,0031 & 0,5282 & 0,3190 & 0,0498 & 0,1342 \\
\hline Nova Itália & 0,0017 & 0,2914 & 0,1074 & 0,3205 & 0,9470 & 0,0441 & 0,7013 & - & 0,4630 & 0,2193 & 0,7683 & 0,0001 & 0,3167 & 0,1288 & 0,2599 & 0,0324 \\
\hline Umariaçu & 0,0001 & 0,0583 & 0,0861 & 0,3205 & 0,8928 & 0,0206 & 0,2607 & 0,6742 & - & 0,2474 & 1,0000 & 0,0000 & 0,1106 & 0,0463 & 0,0714 & 0,0155 \\
\hline Vendaval & 0,0001 & 0,0112 & 1,0000 & 0,0104 & 0,2794 & 0,0015 & 0,1430 & 0,2200 & 0,1734 & - & 0,3475 & 0,0000 & 0,0148 & 0,0219 & 0,0041 & 0,0012 \\
\hline Morada Nova & 0,0011 & 0,1116 & 0,2115 & 0,5787 & 0,7834 & 0,0503 & 0,2921 & 0,7169 & 1,0000 & 0,3207 & - & 0,0000 & 0,2258 & 0,0807 & 0,4544 & 0,0202 \\
\hline Sete Estrelas & 0,1628 & 0,0128 & 0,0000 & 0,0000 & 0,0001 & 0,0217 & 0,0028 & 0,0001 & 0,0000 & 0,0001 & 0,0002 & - & 0,0025 & 0,0504 & 0,0000 & 0,0094 \\
\hline Cana Brava & 0,0902 & 0,4746 & 0,0055 & 0,7561 & 0,3502 & 0,5389 & 0,4208 & 0,2838 & 0,2152 & 0,0172 & 0,2556 & 0,0053 & - & 0,8553 & 0,0458 & 0,5158 \\
\hline Paredão & 0,2190 & 0,4197 & 0,0066 & 0,1806 & 0,1119 & 1,0000 & 0,2489 & 0,0871 & 0,0666 & 0,0161 & 0,0769 & 0,1445 & 0,6721 & - & 0,0025 & 1,0000 \\
\hline Vida Nova & 0,0000 & 0,0505 & 0,0186 & 0,2919 & 0,3060 & 0,0047 & 0,0988 & 0,4100 & 0,3573 & 0,0358 & 0,6609 & 0,0000 & 0,1020 & 0,0130 & - & 0,0000 \\
\hline Yaminawa & 0,1477 & 0,1518 & 0,0007 & 0,0355 & 0,0401 & 0,7757 & 0,1330 & 0,0217 & 0,0166 & 0,0021 & 0,0132 & 0,0399 & 0,2907 & 0,7642 & 0,0023 & - \\
\hline
\end{tabular}


Tabela 6 - Estimativa de valores de $F_{S T}$ população-específicos $\left(F_{S T(k)}\right)$ nas aldeias das tribos Tikúna e Pano (grupo lingüístico), tomando como referencial para cada cálculo a identidade gênica da aldeia $\left(J_{k}\right)$ e a identidade gênica total $\left(J_{T}\right)$ da tribo (grupo lingüístico) a qual a aldeia em questão pertence.

\begin{tabular}{llccc}
\hline Aldeia & Tribo & $J_{k}$ & $J_{T}$ & $F_{S T(k)}$ \\
\hline Belém & Tikúna & 0,4527 & 0,3057 & 0,2117 \\
Bom Jardim & Tikúna & 0,3765 & 0,3057 & 0,1021 \\
Campo Alegre & Tikúna & 0,3233 & 0,3057 & 0,0253 \\
Feijoal & Tikúna & 0,3728 & 0,3057 & 0,0967 \\
Marajá & Tikúna & 0,2686 & 0,3057 & $-0,0534$ \\
Nova Itália & Tikúna & 0,2899 & 0,3057 & $-0,0227$ \\
Umariaçu & Tikúna & 0,3785 & 0,3057 & 0,1049 \\
Vendaval & Tikúna & 0,4140 & 0,3057 & 0,1560 \\
Morada Nova & Katukina (Pano) & 0,4200 & 0,3148 & 0,1536 \\
Sete Estrelas & Katukina (Pano) & 0,6633 & 0,3148 & 0,5086 \\
Cana Brava & Kaxináwa (Pano) & 0,3750 & 0,3148 & 0,0879 \\
Paredão & Kaxináwa (Pano) & 0,5102 & 0,3148 & 0,2852 \\
Vida Nova & Marúbo (Pano) & 0,3889 & 0,3148 & 0,1082 \\
- & Yaminawa (Pano) & 0,4756 & 0,3148 & 0,2347 \\
\hline
\end{tabular}

Analisando-se a matriz de $F_{S T}$ entre pares de aldeias, observa-se grande amplitude de variação nos valores de $F_{S T}$ : $-0,0766$ a 0,4690 (Tabela 4). Verifica-se também que $32(41,56 \%)$ dos 77 pares de aldeia de tribos distintas, $7(46,67 \%)$ dos 15 pares de aldeias Pano e $6(21,43 \%)$ dos 28 pares de aldeia Tikúna diferem significantemente ao nível de 5\% (Tabela 5). A mesma tendência é observada na matriz com valores de probabilidade de não-diferenciação a partir de teste exato: 38 (49,35\%) dos 77 pares de aldeia de tribos distintas, $8(53,33 \%)$ dos 15 pares de aldeias Pano e $6(21,43 \%)$ dos 28 pares de aldeia Tikúna diferem significantemente ao nível de 5\% (Tabela 5).

Para se testar o isolamento tribal dos Tikúna, uma das formas encontradas foi dividir os 77 pares de aldeia de tribos distintas mencionadas no parágrafo anterior em dois grupos: aqueles que comparam uma aldeia Tikúna com aldeia de outra tribo e os que não envolvem qualquer aldeia Tikúna. Assumindo-se nível de significância de 5\%, dos 64 pares de $F_{S T}$ que 
envolvem aldeias Tikúna, 29 (45,31\%) se mostraram significantes, enquanto que apenas $3(23,08 \%)$ dos outros 13 pares foram significantes. Com relação ao teste exato, estes valores aumentam para $33(51,56 \%)$ e $5(38,46 \%)$, respectivamente. Assumindo-se nível de significância de $1 \%$, a diferença entre pares que possuem aldeias Tikúna e os que não possuem fica ainda mais evidente (Tabela 5). Outra forma de se testar a heterogeneidade dos Tikúna foi a partir de comparações entre pares de tribos. Os valores obtidos a partir do cálculo de $F_{S T}$ e do teste exato de diferenciação entre pares de tribos estão apresentados na Tabela 7.

Tabela 7 - Matriz de valores de $F_{S T}$ (abaixo da diagonal) e probabilidade de não-diferenciação obtida a partir de teste exato de diferenciação populacional baseado nas freqüências dos haplogrupos mtDNA (acima da diagonal) entre as sete tribos analisadas no presente estudo. As três primeiras letras do nome de cada tribo foram utilizadas para identificá-las no cabeçalho. Os valores significantes aos níveis de 5\% e 1\% estão destacados em itálico e negrito, respectivamente.

\begin{tabular}{lrrlllll}
\hline & Ban & \multicolumn{1}{l}{ Kan } & \multicolumn{1}{l}{ Tik } & \multicolumn{1}{l}{ Kat } & \multicolumn{1}{l}{ Kax } & Mar & \multicolumn{1}{l}{ Yam } \\
\hline Baníwa & - & 0,2103 & $\mathbf{0 , 0 0 0 0}$ & 0,1373 & 0,0414 & $\mathbf{0 , 0 0 0 0}$ & 0,0366 \\
Kanamari & 0,0067 & - & 0,0237 & 0,6344 & 0,2823 & 0,0216 & 0,1387 \\
Tikúna & $\mathbf{0 , 1 5 6 0}$ & 0,0341 & - & 0,0165 & 0,0245 & 0,0148 & 0,0159 \\
Katukina & 0,0039 & $-0,0124$ & 0,0598 & - & 0,2825 & $\mathbf{0 , 0 0 1 1}$ & 0,4430 \\
Kaxináwa & 0,0774 & 0,0109 & 0,0662 & 0,0238 & - & $\mathbf{0 , 0 0 2 7}$ & 0,7857 \\
Marúbo & $\mathbf{0 , 2 5 8 5}$ & 0,0807 & 0,0382 & $\mathbf{0 , 1 8 1 9}$ & 0,1364 & - & $\mathbf{0 , 0 0 0 0}$ \\
Yaminawa & 0,0487 & 0,0407 & $\mathbf{0 , 1 0 4 8}$ & $-0,0145$ & $-0,0141$ & $\mathbf{0 , 2 5 3 0}$ & - \\
\hline
\end{tabular}

Observa-se que as tribos Marúbo e Tikúna são as duas mais divergentes, sendo que no caso do $F_{S T}$, todos os nove valores significantes encontrados na matriz apresentam uma destas duas tribos envolvidas na comparação. Já pelo teste exato, Marúbo e Tikúna se mostraram significantemente distintas em todas as seis comparações em que estão envolvidas.

Correlação entre as distâncias genéticas $\left(F_{S T}\right)$ e geográficas (presentes na Tabela 4) foi testada com relação às aldeias. Observa-se que ao se considerar todas os 120 pares de aldeias, existe correlação positiva entre as duas variáveis testadas $\left(r_{S}=0,2481 ; p=0,0063\right)$. Já entre 
os 28 pares de aldeias Tikúna $\left(r_{S}=-0,2589 ; p=0,1833\right)$ ou 15 pares de aldeias Pano $\left(r_{S}=0,1828 ; p=0,5143\right)$, não ocorreram correlações significantes.

\subsection{Representação gráfica das distâncias genéticas}

Para se ter idéia exata de como estas populações se relacionam geneticamente, matrizes de distância de Reynolds foram obtidas e representadas graficamente em espaços multidimensionais (MDS). Este método consiste no posicionamento das populações em espaço multidimensional cujas distâncias que separam as populações são proporcionais às distâncias genéticas entre elas.

Para a construção dos gráficos multidimensionais, diferentes soluções foram testadas, variando-se o número de dimensões e modelos: métrico (escala intervalar) e não métrico (escala ordinal). As soluções geradas pelo modelo métrico (M-MDS) resultaram em maior stress e menor correlação entre as distâncias genéticas e as distâncias a partir das coordenadas obtidas. Dessa forma, o modelo não-métrico (NM-MDS) foi o escolhido.

Para a plotagem em gráfico das distâncias genéticas calculadas a partir dos dados das 16 aldeias (Figura 2c), bem como a partir dos dados das sete tribos (Figura 2d), duas dimensões foram suficientes, visto que a inclusão de uma terceira dimensão não leva a alterações substanciais nos valores de stress e $r^{2}$ (Figura 2a,b). É preciso salientar que a análise das sete tribos não permite a possibilidade de representação gráfica em quatro ou mais dimensões, visto que os parâmetros a serem estimados superam os 21 pares de distância que constam da matriz de distância de Reynolds.

No caso da análise de aldeias (Figura 2c), a correspondência entre as distâncias no espaço bi-dimensional e aquelas na matriz de distâncias genéticas é de 98,84\%, sendo o stress 
de apenas 0,0506. Apesar do êxito, poucas conclusões são diretamente obtidas a partir do gráfico. A primeira dimensão permite distinguir razoavelmente os Tikúna (à direita) das demais (à esquerda). Duas aldeias Pano (Morada Nova e Vida Nova) destoam no lado direito, enquanto que Feijoal se insere no lado esquerdo. A segunda dimensão permite diferenciar as duas aldeias Tikúna divergentes (Belém e Vendaval) dentre as demais, pelo agrupamento isolado destas no quadrante inferior direito, assim como a aldeia Pano mais divergente (Sete Estrelas), que se isolou no quadrante inferior esquerdo. Enquanto que as duas aldeias Kaxináwa (Cana Brava e Paredão) se posicionam de maneira relativamente próxima, as duas aldeias Katukina (Morada Nova e Sete Estrelas) ocupam posições totalmente contrastantes no gráfico. A heterogeneidade do grupo lingüístico Pano fica evidente pela dispersão de suas aldeias por ampla área do gráfico.

Já no caso da análise de tribos (Figura 2d), a correspondência entre as distâncias no espaço bi-dimensional e aquelas na matriz de distâncias genéticas é ainda superior (99,95\%), sendo o stress praticamente desprezível $(0,0089)$. A primeira dimensão reflete a divergência das tribos Marúbo e Tikúna em relação às demais. A segunda dimensão reflete o isolamento secundário da tribo Baníwa. A heterogeneidade do grupo lingüístico Pano fica novamente evidente pela dispersão de suas tribos por ampla área do gráfico.

Portanto, enquanto que a primeira dimensão da análise de aldeias leva à separação (imperfeita) dos Tikúna, a segunda evidencia as divergências infra-tribais (Figura 2c). A análise de tribos mostra o isolamento dos Tikúna (Figura 2d), que por sua vez não fica tão evidente assim pela análise de aldeias. Por outro lado, fica cada vez mais claro a heterogeneidade genética dos Pano. 

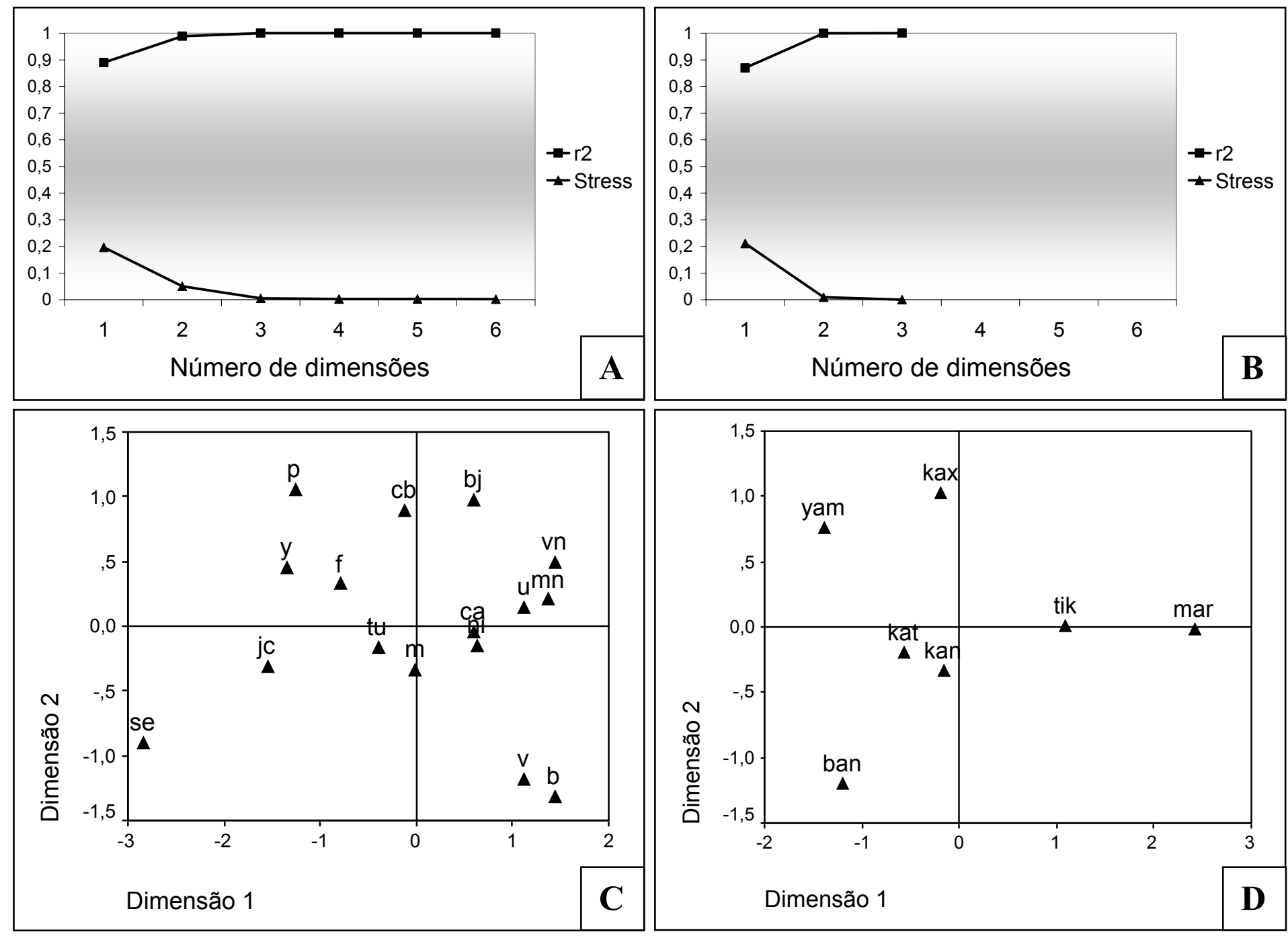

Figura 2. Análise multidimensional (NM-MDS). No alto: gráficos indicando os valores dos índices de performance $\left(r^{2}\right.$ e stress) em função do número de dimensões avaliadas, a partir das matrizes de distância entre (A) aldeias e (B) tribos estudadas. Abaixo: representação em espaço bi-dimensional das distâncias genéticas de Reynolds. As distâncias foram estimadas entre as (C) 16 aldeias e (D) sete tribos estudadas, a partir das freqüências dos haplogrupos de mtDNA. 
Tabela 8 - Partição da variância de freqüências dos haplogrupos de mtDNA em diferentes níveis hierárquicos (AMOVA) segundo seis formas de agrupamento das 16 aldeias analisadas no presente estudo.

\begin{tabular}{|c|c|c|c|c|c|}
\hline \multirow[b]{2}{*}{$N^{1}$} & \multirow[b]{2}{*}{ Critério de agrupamento } & \multirow[b]{2}{*}{ Composição dos grupos $^{2}$} & \multicolumn{2}{|l|}{ Proporção } & \multirow{2}{*}{$\begin{array}{l}\text { variância } \\
\text { dentro de aldeias } \\
\qquad\left(F_{S T}\right)\end{array}$} \\
\hline & & & $\begin{array}{l}\text { entre grupos } \\
\qquad\left(F_{C T}\right)\end{array}$ & $\begin{array}{l}\text { entre aldeias dentro de } \\
\text { grupos }\left(F_{S C}\right)\end{array}$ & \\
\hline 1 & $\begin{array}{l}\text { Ausência de estrutura } \\
\text { hierárquica }\end{array}$ & $\begin{array}{l}\text { (1) JC, TU, B, V, BJ, CA, F, M, NI, U, MN, SE, CB, P, } \\
\text { VN, Y. }\end{array}$ & - & $\begin{array}{c}10,18 \% \\
(0,1018 ; p=0,0000)\end{array}$ & $89,82 \%$ \\
\hline 2 & Estoque lingüístico & $\begin{array}{l}\text { (1) JC, TU, B, V, BJ, CA, F, M, NI, U. } \\
\text { (2) MN, SE, CB, P, VN, Y. }\end{array}$ & $\begin{array}{c}0,01 \% \\
(0,0001 ; p=0,3500)\end{array}$ & $\begin{array}{c}10,17 \% \\
(0,1017 ; p=0,0000)\end{array}$ & $\begin{array}{c}89,82 \% \\
(0,1018 ; p=0,0000)\end{array}$ \\
\hline 4 & Língua falada & $\begin{array}{l}\text { (1) JC. (2) TU. (3) B, V, BJ, CA, F, M, NI, U. } \\
\text { (4) } \mathrm{MN}, \mathrm{SE}, \mathrm{CB}, \mathrm{P}, \mathrm{VN}, \mathrm{Y} \text {. }\end{array}$ & $\begin{array}{c}2,50 \% \\
(0,0250 ; p=0,1699)\end{array}$ & $\begin{array}{c}8,58 \% \\
(0,0880 ; p=0,0000)\end{array}$ & $\begin{array}{c}88,92 \% \\
(0,1108 ; p=0,0000)\end{array}$ \\
\hline 7 & Afiliação tribal & $\begin{array}{l}\text { (1) JC. (2) TU. (3) B, V, BJ, CA, F, M, NI, U. } \\
\text { (4) } \mathrm{MN} \text {, SE. (5) } \mathrm{CB}, \mathrm{P} . \quad \text { (6) } \mathrm{VN} . \quad \text { (7) } \mathrm{Y} .\end{array}$ & $\begin{array}{c}3,97 \% \\
(0,0397 ; p=0,1527)\end{array}$ & $\begin{array}{c}7,47 \% \\
(0,0778 ; p=0,0000)\end{array}$ & $\begin{array}{c}88,57 \% \\
(0,1143 ; p=0,0000)\end{array}$ \\
\hline 8 & $\begin{array}{l}\text { Heterogeneidade infra-tribal } \\
\text { (apenas nos Katukina) }\end{array}$ & 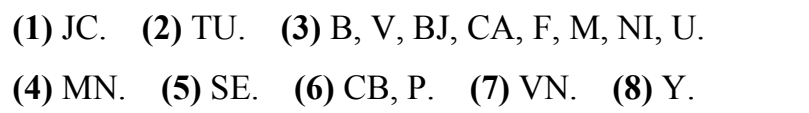 & $\begin{array}{c}8,80 \% \\
(0,0880 ; p=0,0149)\end{array}$ & $\begin{array}{c}4,14 \% \\
(0,0454 ; p=0,0096)\end{array}$ & $\begin{array}{c}87,06 \% \\
(0,1294 ; p=0,0000)\end{array}$ \\
\hline 9 & $\begin{array}{l}\text { Heterogeneidade infra-tribal } \\
\text { (nos Katukina e Tikúna) }\end{array}$ & 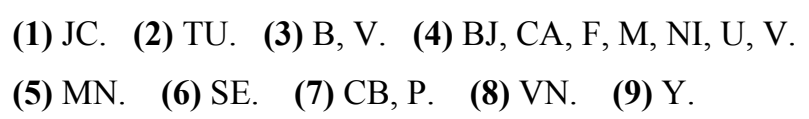 & $\begin{array}{c}11,71 \% \\
(0,1171 ; p=0,0003)\end{array}$ & $\begin{array}{c}0,52 \% \\
(0,0059 ; p=0,0210)\end{array}$ & $\begin{array}{c}87,76 \% \\
(0,1224 ; p=0,0000)\end{array}$ \\
\hline
\end{tabular}

Número de grupos que compõem a estrutura hierárquica;

${ }^{2}$ As letras iniciais dos nomes das aldeias foram utilizadas para identificá-las. 


\subsection{Análise de Variância Molecular}

Três estruturas hierárquicas foram inicialmente testadas a fim de verificar a qual delas os dados de mtDNA se ajustam de maneira mais adequada (Tabela 8), maximizando a proporção da variância genética total devido a diferença entre grupos $\left(F_{C T}\right)$ e minimizando a diferença entre aldeias de mesmo grupo $\left(F_{S C}\right)$ (Dupanloup et al. 2002). Como controle, temos ainda a estrutura simples (ausência de estrutura), na qual todas as 16 aldeias fazem parte de um mesmo grupo $\left(F_{S C}=0,1018\right.$, valor correspondente ao de $F_{S T}$ apresentado na Tabela 3$)$.

Visto que nenhuma das três estruturas testadas apresentou $F_{C T}$ elevado e significante, analisamos duas outras hierarquias derivadas do agrupamento por afiliação tribal, fundamentadas nas informações sobre estruturação tribal já discutidas. Na primeira delas a tribo Katukina foi fragmentada, formando dois grupos distintos; na segunda delas, além desta modificação, a tribo Tikúna também foi fragmentada, sendo que as aldeias que apresentaram elevados valores de $F_{S T(\mathrm{k})}$ (Belém e Vendaval) passaram a formar grupo à parte. Pode-se observar que nesta última estrutura hierárquica os dados se ajustaram de maneira mais adequada aos critérios estabelecidos (Tabela 8).

\subsection{AIDA}

A fim de se analisar a correlação entre alelos de indivíduos ao longo do espaço geográfico compreendido por estas aldeias aqui analisadas, o coeficiente de correlação II foi computado em oito classes de distâncias (Figura 3). Adotando-se o critério de Bonferroni, o correlograma como um todo foi considerado significante ao nível de 5\%. Observa-se autocorrelação positiva significante nas duas primeiras classes de distâncias decrescendo para valores 
negativos (não-significantes) até a quarta classe. Na quinta classe ocorre ligeiro aumento no valor de $I I$, que chega a atingir valor positivo, com posterior decréscimo. Na sétima classe observa-se uma depressão significante. Conclui-se que as populações separadas por até 70 quilômetros são geneticamente semelhantes enquanto que existem maiores diferenças entre populações separadas por cerca de 490 e 580 quilômetros de distância. Tal classe de distâncias envolve boa parte das comparações entre aldeias Tikúna e aldeias Pano, bem como algumas comparações entre aldeias Tikúna e Jandu Cachoeira (Baníwa).

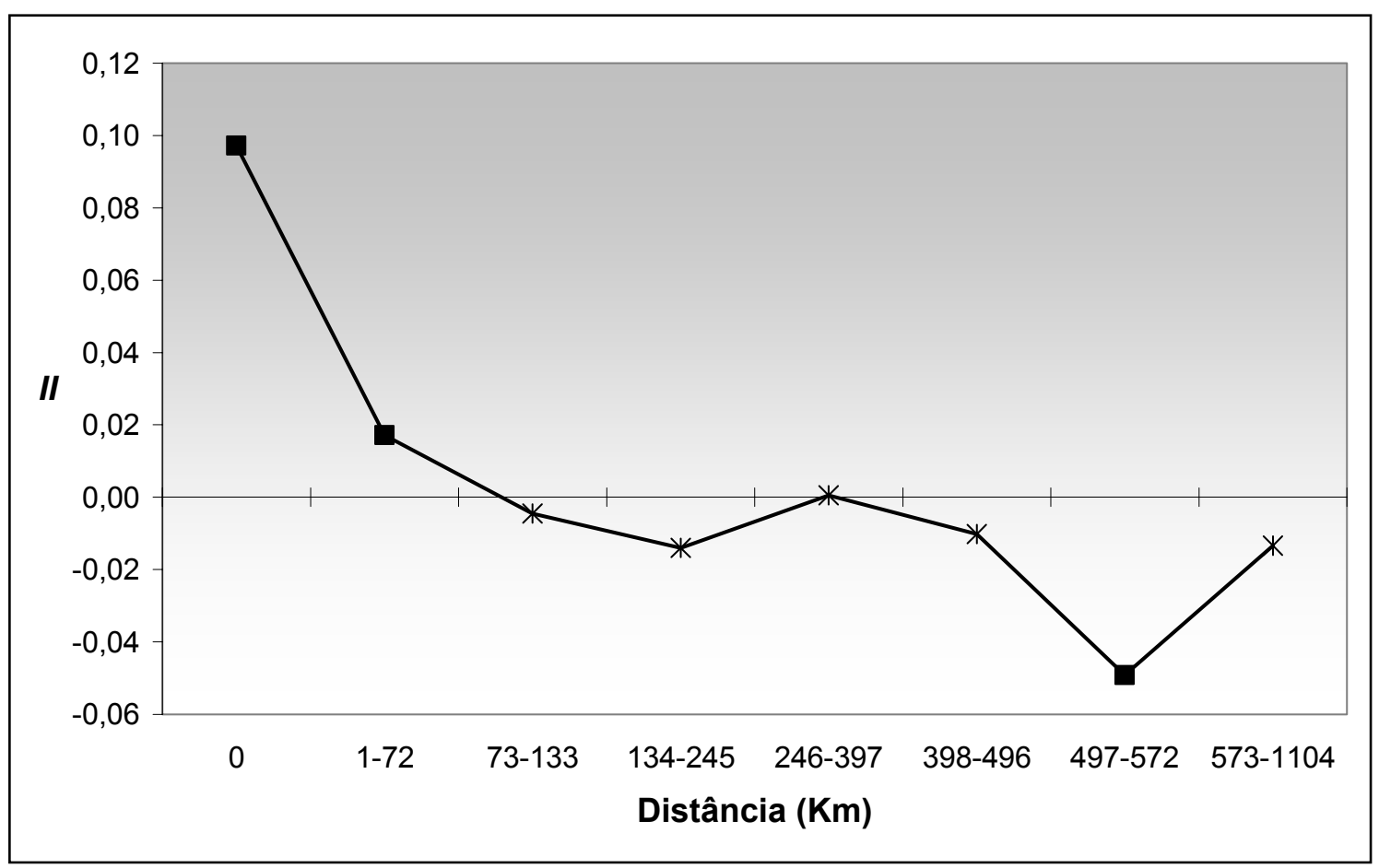

Figura 3. Correlograma espacial obtido a partir dos haplogrupos de mtDNA de 307 indivíduos pertencentes às aldeias aqui analisadas. Os limites dos intervalos de distância foram construídos de modo que cada um deles incorpore aproximadamente o mesmo número de pares de indivíduos. Os índices $I I$ estão dispostos sobre o valores médios dos intervalos de distância, sendo que os quadrados ( $\mathbf{\square})$ indicam os índices diferentes de zero ao nível de significância de $1 \%(\mathrm{p}<0,01)$ e os asteriscos $(*)$ representam índices não-significantes $(\mathrm{p}>0,05)$. 


\subsection{Diversidade inter-populacional: mtDNA e cromossomo $Y$}

Para identificar eventuais padrões de divergência sexo-específicas, comparando-se dados de mtDNA e cromossomo Y, foi utilizado apenas 7 aldeias (Jandu Cachoeira, Três Unidos, Belém, Feijoal, Umariaçu, Vendaval e Cana Brava) dentre as 16 aqui estudadas, uma vez que são as únicas nas quais polimorfismos do Y foram analisados. Os dados de Y abrangem 140 haplótipos formados por cinco microssatélites (Wanderley-Santos et al. 2005).

Observa-se nas sete aldeias valor de $F_{S T}$ maior quando considerados os cromossomos $\mathrm{Y}\left(F_{S T}=0,2612 ; p=0,0000\right)$ do que os de $\operatorname{mtDNA}\left(F_{S T}=0,1213 ; p=0,0000\right)$, embora ambos sejam igualmente significantes do ponto de vista estatístico. Agrupando estas sete aldeias de acordo com suas tribos, este padrão se repete: os haplótipos do cromossomo $\mathrm{Y}\left(F_{S T}=0,3482\right.$; $p=0,0000)$ novamente indicam maior estruturação do que os haplogrupos de mtDNA $\left(F_{S T}=0,0986 ; p=0,0001\right)$. Se forem consideradas apenas as quatro aldeias Tikúna que vinham sendo estudadas, Belém, Feijoal, Umariaçu e Vendaval, tal padrão supracitado se inverte: o valor de $F_{S T}$ obtido com base nos haplogrupos de mtDNA $\left(F_{S T}=0,1057\right.$; $p=0,0011)$ é surpreendentemente superior ao obtido pela análise dos haplótipos do cromossomo Y $\left(F_{S T}=0,0212 ; p=0,0918\right)$.

Correlações foram testadas entre as matrizes de distâncias genéticas $\left(F_{S T}\right)$ e distâncias geográficas (Tabelas 9 e 10). Não houve correlação entre as distâncias obtidas a partir do Y e mtDNA $\left(r_{S}=-0,1000 ; p=0,6663\right)$. Enquanto que as distâncias genéticas obtidas a partir dos microssatélites de $\mathrm{Y}$ se mostraram altamente correlacionadas às distâncias geográficas $\left(r_{S}=0,6481 ; p=0,0015\right)$, o mesmo não ocorreu com as obtidas pelo mtDNA $\left(r_{S}=0,1935\right.$; $p=0,4006)$ 
Tabela 9 - Matriz de valores de $F_{S T}$ (abaixo da diagonal) e respectivas probabilidades (acima da diagonal) obtidas a partir da análise de haplótipos de microssatélites do cromossomo $\mathrm{Y}$, entre sete aldeias da região Centro-Oeste da Amazônia. As letras iniciais dos nomes das aldeias foram utilizadas para identificá-las no cabeçalho. Os valores de significantes aos níveis de $5 \%$ e $1 \%$ estão destacados em itálico e negrito, respectivamente.

\begin{tabular}{lrrrrrrr}
\hline & \multicolumn{1}{c}{$J C$} & $T U$ & $B$ & $F$ & $U$ & $V$ & $C B$ \\
\hline Jandu Cachoeira & - & $\mathbf{0 , 0 0 0 0}$ & $\mathbf{0 , 0 0 0 0}$ & $\mathbf{0 , 0 0 0 0}$ & $\mathbf{0 , 0 0 0 0}$ & $\mathbf{0 , 0 0 0 0}$ & $\mathbf{0 , 0 0 0 0}$ \\
Três Unidos & $\mathbf{0 , 3 7 2 4}$ & - & $\mathbf{0 , 0 0 0 0}$ & $\mathbf{0 , 0 0 0 0}$ & $\mathbf{0 , 0 0 0 0}$ & $\mathbf{0 , 0 0 0 0}$ & 0,2840 \\
Belém & $\mathbf{0 , 2 3 4 5}$ & $\mathbf{0 , 3 1 6 7}$ & - & 0,0924 & 0,2439 & 0,2318 & $\mathbf{0 , 0 0 0 0}$ \\
Feijoal & $\mathbf{0 , 3 6 3 6}$ & $\mathbf{0 , 4 3 8 3}$ & 0,0354 & - & 0,1157 & 0,1655 & $\mathbf{0 , 0 0 0 0}$ \\
Umariaçu & $\mathbf{0 , 3 0 4 8}$ & $\mathbf{0 , 3 5 9 4}$ & 0,0106 & 0,0317 & - & 0,1931 & $\mathbf{0 , 0 0 0 0}$ \\
Vendaval & $\mathbf{0 , 2 9 7 0}$ & $\mathbf{0 , 3 7 4 8}$ & 0,0115 & 0,0219 & 0,0183 & - & $\mathbf{0 , 0 0 0 0}$ \\
Cana Brava & $\mathbf{0 , 5 3 9 2}$ & 0,0511 & $\mathbf{0 , 4 4 9 7}$ & $\mathbf{0 , 5 8 1 2}$ & $\mathbf{0 , 4 9 3 6}$ & $\mathbf{0 , 5 1 3 1}$ & - \\
\hline
\end{tabular}

Tabela 10 - Matriz de valores de $F_{S T}$ obtidos a partir das freqüências dos haplogrupos de mtDNA (abaixo da diagonal) e de distâncias geográficas em quilômetros (acima da diagonal) entre as sete aldeias que tiveram haplótipos de microssatélites do cromossomo Y determinados. As letras iniciais dos nomes das aldeias foram utilizadas para identificá-las no cabeçalho. Os valores de $F_{S T}$ significantes aos níveis de $5 \%$ e $1 \%$ estão destacados em itálico e negrito, respectivamente. (Observação: Estas matrizes correspondem exatamente a versões reduzidas daquelas apresentadas na Tabela 4).

\begin{tabular}{lrrrrrrr}
\hline & \multicolumn{1}{c}{$J C$} & \multicolumn{1}{c}{$T U$} & \multicolumn{1}{c}{$B$} & \multicolumn{1}{c}{$F$} & \multicolumn{1}{c}{$U$} & \multicolumn{1}{c}{$C B$} \\
\hline Jandu Cachoeira & 0 & 907,41 & 612,41 & 648,27 & 658,31 & 564,06 & 1083,29 \\
Três Unidos & 0,0067 & 0 & 298,72 & 261,77 & 261,50 & 344,77 & 87,08 \\
Belém & $\mathbf{0 , 3 0 7 2}$ & $\mathbf{0 , 1 6 0 9}$ & 0 & 37,04 & 52,47 & 49,65 & 470,88 \\
Feijoal & 0,0297 & $-0,0041$ & $\mathbf{0 , 2 2 5 8}$ & 0 & 37,19 & 84,25 & 435,23 \\
Umariaçu & $\mathbf{0 , 2 3 1 4}$ & 0,0697 & 0,0622 & 0,1021 & 0 & 100,94 & 426,22 \\
Vendaval & $\mathbf{0 , 2 6 6 6}$ & 0,1220 & $-0,0393$ & $\mathbf{0 , 1 8 0 0}$ & 0,0330 & 0 & 519,47 \\
Cana Brava & 0,0816 & $-0,0159$ & $\mathbf{0 , 2 1 5 2}$ & $-0,0316$ & 0,0288 & 0,1653 & 0 \\
\hline
\end{tabular}

\subsection{Meta-análise em escala continental}

Dados de aproximadamente 108 populações da América do Norte e de 178 populações da América do Sul foram adicionados aos do presente estudo (Apêndice A). Nesta compilação, além de populações nativo-americanas, foram incluídas também populações urbanas e miscigenadas em geral. Populações cujas coordenadas geográficas não eram informadas nos 
respectivos artigos, tiveram tais dados inferidos a partir das posições que ocupavam nos mapas geográficos. Embora erros de aproximação possam ser inseridos por este procedimento, tais erros são desprezíveis para as análises em escalas continentais (TarazonaSantos et al. 2001a). A afiliação lingüística de cada população nativo-americana foi realizada de acordo classificação proposta por Greenberg (1987).

Populações que apresentavam menos do que cinco exemplares de haplogrupos nativo-americanos não foram utilizadas em qualquer das análises posteriores e por isso não tiveram suas coordenadas geográficas e afiliações lingüísticas determinadas. Também foram excluídas das análises duas populações nipo-descendentes (visto que a ocorrência de haplogrupos A, B, C e D raramente é de origem indígena nestas populações, mas sim asiática), duas amostras compostas por indivíduos de oito paises da América do Sul e dois conjuntos de amostras de ossos antigos, coletadas em diversas localidades cobrindo ampla extensão geográfica. Também foi descartada a amostra populacional de Aicuña (população rural da Argentina), uma vez que destoa de maneira extrema em relação às demais populações da região em que se insere, gerando fortes distorções se inserida nos mapas geográficos de freqüências de cada haplogrupo. A presença quase fixada do haplogrupo A em tal população é decorrente de forte efeito do fundador, provocado quando apenas um casal se estabeleceu no local no início do século 17 (Bailliet et al. 2001).

Análise de variância molecular foi empregada para visualização da partição da variância em várias estruturas hierárquicas, adotando-se critérios geográficos (Tabela 11) e lingüísticos (Tabela 12). Qualquer que seja a estrutura hierárquica adotada e o conjunto de populações analisadas, a maior parte da variância $(61,27 \%$ - 87,08\%) sempre decorre de diferenças entre indivíduos dentro de aldeias. 
Tabela 11 - Partição da variância de freqüências dos haplogrupos de mtDNA em diferentes níveis hierárquicos (AMOVA), adotando-se critérios geográficos. Os valores são significantes ao nível de $1 \%(\mathrm{p}<0,01)$, exceto o único destacado.

\begin{tabular}{|c|c|c|c|c|}
\hline$N^{l}$ & Composição dos grupos $^{2}$ & $\begin{array}{l}\text { Proporção } \\
\text { entre grupos } \\
\left(F_{C T}\right)\end{array}$ & $\begin{array}{c}\text { da } \\
\text { entre aldeias } \\
\text { dentro de } \\
\text { grupos }\left(F_{S C}\right)\end{array}$ & $\begin{array}{l}\text { variância } \\
\text { dentro de } \\
\text { aldeias }\left(F_{S T}\right)\end{array}$ \\
\hline 1 & $\begin{array}{l}\text { (1) } 245 \text { populações das Américas (ausência de } \\
\text { estrutura hierárquica) }(\mathrm{AmN}+\mathrm{AmC}+\mathrm{AmS})\end{array}$ & - & $\begin{array}{l}30,30 \% \\
(0,3030)\end{array}$ & $69,70 \%$ \\
\hline 2 & $\begin{array}{l}\text { (1) } 94 \text { populações da América do Norte } \\
\text { (2) } 151 \text { populações da América do Sul }\end{array}$ & $\begin{array}{c}5,65 \% \\
(0,0565)\end{array}$ & $\begin{array}{l}26,63 \% \\
(0,2823)\end{array}$ & $\begin{array}{l}67,72 \% \\
(0,3228)\end{array}$ \\
\hline 3 & $\begin{array}{l}\text { (1) } 80 \text { populações da América do Norte }(\mathrm{AmN}) \\
\text { (2) } 28 \text { populações da América Central }(\mathrm{AmC}) \\
\text { (3) } 137 \text { populações da América do Sul }(\mathrm{AmS})\end{array}$ & $\begin{array}{c}6,74 \% \\
(0,0674)\end{array}$ & $\begin{array}{l}25,58 \% \\
(0,2743)\end{array}$ & $\begin{array}{l}67,68 \% \\
(0,3232)\end{array}$ \\
\hline 11 & $\begin{array}{l}11 \text { regiões das Américas: } \\
\text { Vide Apêndice A (total: } 245 \text { populações) }\end{array}$ & $\begin{array}{l}10,21 \% \\
(0,1021)\end{array}$ & $\begin{array}{l}21,21 \% \\
(0,2362)\end{array}$ & $\begin{array}{l}68,58 \% \\
(0,3142)\end{array}$ \\
\hline 1 & $\begin{array}{l}\text { (1) } 92 \text { populações da América do Norte } \\
(\mathrm{AmN}+\mathrm{AmC}, \mathrm{Not})\end{array}$ & - & $\begin{array}{l}31,51 \% \\
(0,3151)\end{array}$ & $69,49 \%$ \\
\hline 5 & $\begin{array}{l}5 \text { regiões da América do Norte: } \\
\text { Vide Apêndice A (total: } 92 \text { populações) }\end{array}$ & $\begin{array}{l}10,53 \% \\
(0,1053)\end{array}$ & $\begin{array}{l}22,69 \% \\
(0,2536)\end{array}$ & $\begin{array}{l}66,78 \% \\
(0,3322)\end{array}$ \\
\hline 1 & $\begin{array}{l}\text { (1) } 149 \text { populações da América do Sul } \\
\text { (AmS + AmC,Sul) }\end{array}$ & - & $\begin{array}{l}25,68 \% \\
(0,2568)\end{array}$ & $74,32 \%$ \\
\hline 5 & $\begin{array}{l}5 \text { regiões da América do Sul: } \\
\text { Vide Apêndice A (total: } 149 \text { populações) }\end{array}$ & $\begin{array}{c}6,74 \% \\
(0,0674)\end{array}$ & $\begin{array}{l}20,79 \% \\
(0,2229)\end{array}$ & $\begin{array}{l}72,47 \% \\
(0,3322)\end{array}$ \\
\hline 2 & $\begin{array}{l}\text { (1) Leste Am. Sul (Ama }+\mathrm{GrC}-68 \text { populações) } \\
\text { (2) Oeste Am. Sul (And }+\mathrm{TdF}-69 \text { populações) }\end{array}$ & $\begin{array}{c}\mathbf{0 , 3 3 \%} \\
(\mathbf{0 , 0 0 3 3 )} \\
(p=\mathbf{0 , 1 8 2 3 )}\end{array}$ & $\begin{array}{l}24,18 \% \\
(0,2427)\end{array}$ & $\begin{array}{l}75,48 \% \\
(0,2452)\end{array}$ \\
\hline 1 & Leste Am. do Sul (Ama + GrC - 68 populações) & - & $25,29 \%$ & $74,71 \%$ \\
\hline 1 & Oeste Am. do Sul (And + TdF - 69 populações) & - & $23,49 \%$ & $76,51 \%$ \\
\hline 1 & Sul da América Central (Sul - 12 populações) & - & $17,77 \%$ & $82,23 \%$ \\
\hline 1 & Amazônia (Ama - 57 populações) & - & $24,42 \%$ & $75,58 \%$ \\
\hline 1 & Grande Chaco ( $\mathrm{GrC}-11$ populações) & - & $12,92 \%$ & $87,08 \%$ \\
\hline 1 & Andes (And - 64 populações) & - & $22,42 \%$ & $77,58 \%$ \\
\hline 1 & Tierra del Fuego ( $\mathrm{TdF}$ - 5 populações) & - & $22,80 \%$ & $77,20 \%$ \\
\hline
\end{tabular}

\footnotetext{
1 Número de grupos que compõem a estrutura hierárquica;

${ }^{2}$ As populações utilizadas são as populações nativo-americanas que tiveram suas áreas geográficas determinadas no Apêndice A. Os códigos entre parênteses referem-se às áreas geográficas determinadas em tal apêndice.
} 
Tabela 12 - Partição da variância de freqüências dos haplogrupos de mtDNA em diferentes níveis hierárquicos (AMOVA), adotando-se critérios lingüísticos (Greenberg, 1987). Todos os valores são significantes ao nível de $1 \%(\mathrm{p}<0,01)$.

\begin{tabular}{|c|c|c|c|c|}
\hline$N^{l}$ & Composição dos grupos ${ }^{2}$ & $\begin{array}{l}\text { Proporção } \\
\text { entre grupos } \\
\left(F_{C T}\right)\end{array}$ & $\begin{array}{c}d a \\
\text { entre aldeias } \\
\text { dentro de } \\
\text { grupos }\left(F_{S C}\right)\end{array}$ & $\begin{array}{l}\text { variância } \\
\text { dentro de } \\
\text { aldeias }\left(F_{S T}\right)\end{array}$ \\
\hline 1 & $\begin{array}{l}\text { (1) } 233 \text { populações das Américas (ausência de } \\
\text { estrutura hierárquica) }\end{array}$ & - & $\begin{array}{l}30,92 \% \\
(0,3092)\end{array}$ & $69,08 \%$ \\
\hline 3 & $\begin{array}{l}\text { (1) } 17 \text { populações Esquimós-Aleutas (EA) } \\
\text { (2) } 8 \text { populações Na-Dene (ND) } \\
\text { (3) } 208 \text { populações Ameríndias (Am) }\end{array}$ & $\begin{array}{r}17,01 \% \\
(0,1701)\end{array}$ & $\begin{array}{l}21,72 \% \\
(0,2617)\end{array}$ & $\begin{array}{r}61,27 \% \\
(0,3873)\end{array}$ \\
\hline 10 & $\begin{array}{l}10 \text { estoques lingüísticos das Américas: } \\
\text { Vide Apêndice A (total: } 233 \text { populações) }\end{array}$ & $\begin{array}{r}11,30 \% \\
(0,1130)\end{array}$ & $\begin{array}{l}20,65 \% \\
(0,2328)\end{array}$ & $\begin{array}{r}68,05 \% \\
(0,3195)\end{array}$ \\
\hline 21 & $\begin{array}{l}21 \text { subgrupos lingüísticos das Américas: } \\
\text { Vide Apêndice A (total: } 228 \text { populações) }\end{array}$ & $\begin{array}{r}15,03 \% \\
(0,1503)\end{array}$ & $\begin{array}{l}16,76 \% \\
(0,1973)\end{array}$ & $\begin{array}{r}68,21 \% \\
(0,3179)\end{array}$ \\
\hline 1 & (1) 88 populações da América do Norte & - & $\begin{array}{l}31,88 \% \\
(0,3188)\end{array}$ & $68,12 \%$ \\
\hline 3 & $\begin{array}{l}3 \text { famílias lingüísticas da Am. do Norte: } \\
\text { Vide Apêndice A (total: } 88 \text { populações) }\end{array}$ & $\begin{array}{r}14,80 \% \\
(0,1480)\end{array}$ & $\begin{array}{l}21,00 \% \\
(0,2465)\end{array}$ & $\begin{array}{l}64,20 \% \\
(0,3580)\end{array}$ \\
\hline 6 & $\begin{array}{l}6 \text { estoques lingüísticos da Am. do Norte: } \\
\text { Vide Apêndice A (total: } 88 \text { populações) }\end{array}$ & $\begin{array}{r}16,21 \% \\
(0,1621)\end{array}$ & $\begin{array}{l}18,51 \% \\
(0,2210)\end{array}$ & $\begin{array}{r}65,28 \% \\
(0,3473)\end{array}$ \\
\hline 11 & $\begin{array}{l}11 \text { grupos lingüísticos da Am. do Norte: } \\
\text { Vide Apêndice A (total: } 88 \text { populações) }\end{array}$ & $\begin{array}{l}20,26 \% \\
(0,2026)\end{array}$ & $\begin{array}{r}13,33 \% \\
(0,1671)\end{array}$ & $\begin{array}{r}66,41 \% \\
(0,3359)\end{array}$ \\
\hline 1 & (1) 145 populações da América do Sul & - & $\begin{array}{l}26,32 \% \\
(0,2632)\end{array}$ & $73,68 \%$ \\
\hline 4 & $\begin{array}{l}4 \text { estoques lingüísticos da Am. do Sul: } \\
\text { Vide Apêndice A (total: } 145 \text { populações) }\end{array}$ & $\begin{array}{c}4,39 \% \\
(0,0439)\end{array}$ & $\begin{array}{l}22,78 \% \\
(0,2383)\end{array}$ & $\begin{array}{r}72,83 \% \\
(0,2717)\end{array}$ \\
\hline 10 & $\begin{array}{l}10 \text { grupos lingüísticos da Am. do Sul: } \\
\text { Vide Apêndice A (total: } 140 \text { populações) }\end{array}$ & $\begin{array}{c}7,55 \% \\
(0,0755)\end{array}$ & $\begin{array}{r}19,75 \% \\
(0,2136)\end{array}$ & $\begin{array}{r}72,70 \% \\
(0,2730)\end{array}$ \\
\hline
\end{tabular}

${ }_{1}^{1}$ Número de grupos que compõem a estrutura hierárquica;

2 As populações utilizadas são as populações nativo-americanas que tiveram suas afiliações lingüísticas determinadas no Apêndice A. Os códigos entre parênteses referem-se aos grupos lingüísticos determinadas em tal apêndice.

Nas análises de estruturas elaboradas de acordo com critérios geográficos (Tabela 11), foram utilizadas no máximo 245 populações contidas no intervalo entre os códigos N001 e N103 e entre S001 e S155 (Apêndice A), justamente aquelas que foram alocadas em uma das áreas geográficas. De modo geral (Tabela 11), observa-se que existem diferenças significantes 
$(\mathrm{p}<0,01)$ entre (a) grupos de populações de diferentes continentes $\left(F_{C T}\right.$ varia de 0,0565 a 0,1021), (b) grupos de populações de diferentes regiões geográficas do mesmo continente ( $F_{C T}$ de 0,0674 na América do Sul e 0,1053 na América do Norte) e (c) entre populações de mesma região geográfica ( $F_{S C}$ varia de 0,1292 nos Chacos a 0,2442 na Amazônia). Todavia não se observa diferença entre as porções leste e oeste da América do $\operatorname{Sul}\left(F_{C T}=0,0033\right.$; $p=0,1823$ ), sendo que a variância entre as populações pertencentes a cada uma destas duas regiões geográficas é quase idêntica $\left(F_{C T}=0,2529\right.$ no Leste; $F_{C T}=0,2349$ no Oeste).

Já nas análises de estruturas organizadas a partir de critérios lingüísticos (Tabela 12), foram aproveitadas apenas 233 das 245 populações utilizadas nas análises baseadas em critérios geográficos, pois a classificação lingüística de Greenberg (1987) não se aplicava a 12 delas (oito grupos antigos e quatro populações contemporâneas de línguas não identifícadas). Nota-se, diferenças estatisticamente significantes $(\mathrm{p}<0,01)$ entre as famílias lingüísticas $\left(F_{C T}\right.$ de 0,1701 nas Américas e 0,1480 na América do Norte), estoques lingüísticos ( $F_{C T}$ varia de $0,0439$ a 0,1621$)$ e subgrupos lingüísticos $\left(F_{C T}\right.$ varia de 0,0755 a 0,2026$)$. No caso de grupos formados de acordo com estoque ou subgrupo lingüístico, obtém-se menor variância entre grupos na América do Sul do que na América do Norte, sendo que o resultado encontrado nas Américas referentes a estas duas formas de agrupamento é próximo da média dos dois continentes separados (Tabela 12).

AMOVA deixou evidente que tanto a geografia quanto a afiliação lingüística exercem forte influência na variabilidade do DNA mitocondrial nas Américas. Entretanto, a limitação desta abordagem está no fato de que até mesmo padrões complexos acabam sendo resumidos por alguns valores calculados. Embora muitas conclusões possam ser obtidas desta forma, descrições mais detalhadas da diversidade geográfica são muitas vezes necessárias (Barbujani 2000). Sendo assim, correlogramas e distogramas foram obtidos a fim de trazer informações 
sobre como os padrões de variabilidade genética das populações nativo-americanas são influenciados pela geografia.

Para a análise de autocorrelação espacial (AIDA) foram consideradas as populações que se encontravam no intervalo entre os códigos N001 e N103 e entre S001 e S155 (Apêndice A), sendo excluídas, como já explicado, aquelas que não tiveram suas coordenadas geográficas e afiliações lingüísticas determinadas. Correlogramas relativos ao continente americano, à América do Norte e à América do Sul estão apresentados na Figura 4. O correlograma da América do Norte (Figura 4b) foi baseado em 94 amostras populacionais.

Devido à limitação de no máximo 99 amostras populacionais em cada análise (embora teoricamente a limitação fosse de 160 populações em cada análise, durante as análises foi constatado erro no programa AIDA ao se utilizar simultaneamente cem ou mais populações: o número total de indivíduos confirmado pelo programa passa a diferir do número real de indivíduos que consta nos bancos de dados, erro este que persiste durante o cálculo dos índices de correlação), os correlogramas relativos ao continente americano e à América do Sul foram construídos com número limitado de populações, excluindo-se aquelas com menor tamanho amostral. No caso do continente americano (Figura 4a), dentre as 245 amostras foram selecionadas 48 da América do Norte (com mais de 25 haplogrupos nativo-americanos) e 51 da América do Sul (com mais de 29 haplogrupos nativo-americanos), totalizando 99 amostras populacionais. No caso da América do Sul (Figura 4c), das 151 amostras foram selecionadas as 92 que possuíam mais de 20 haplogrupos de origem nativo-americana. A fim de verificar se diferentes esquemas de seleção de amostras influenciariam na configuração dos correlogramas, outro correlograma relativo à América do Sul foi obtido agrupando-se as 151 populações de acordo com a afiliação tribal, o que resultou em 96 amostras populacionais (Figura 4c). Neste caso, quando duas ou mais aldeias foram agrupadas em uma tribo, as coordenadas geográficas de uma delas foram mantidas para a tribo formada. 

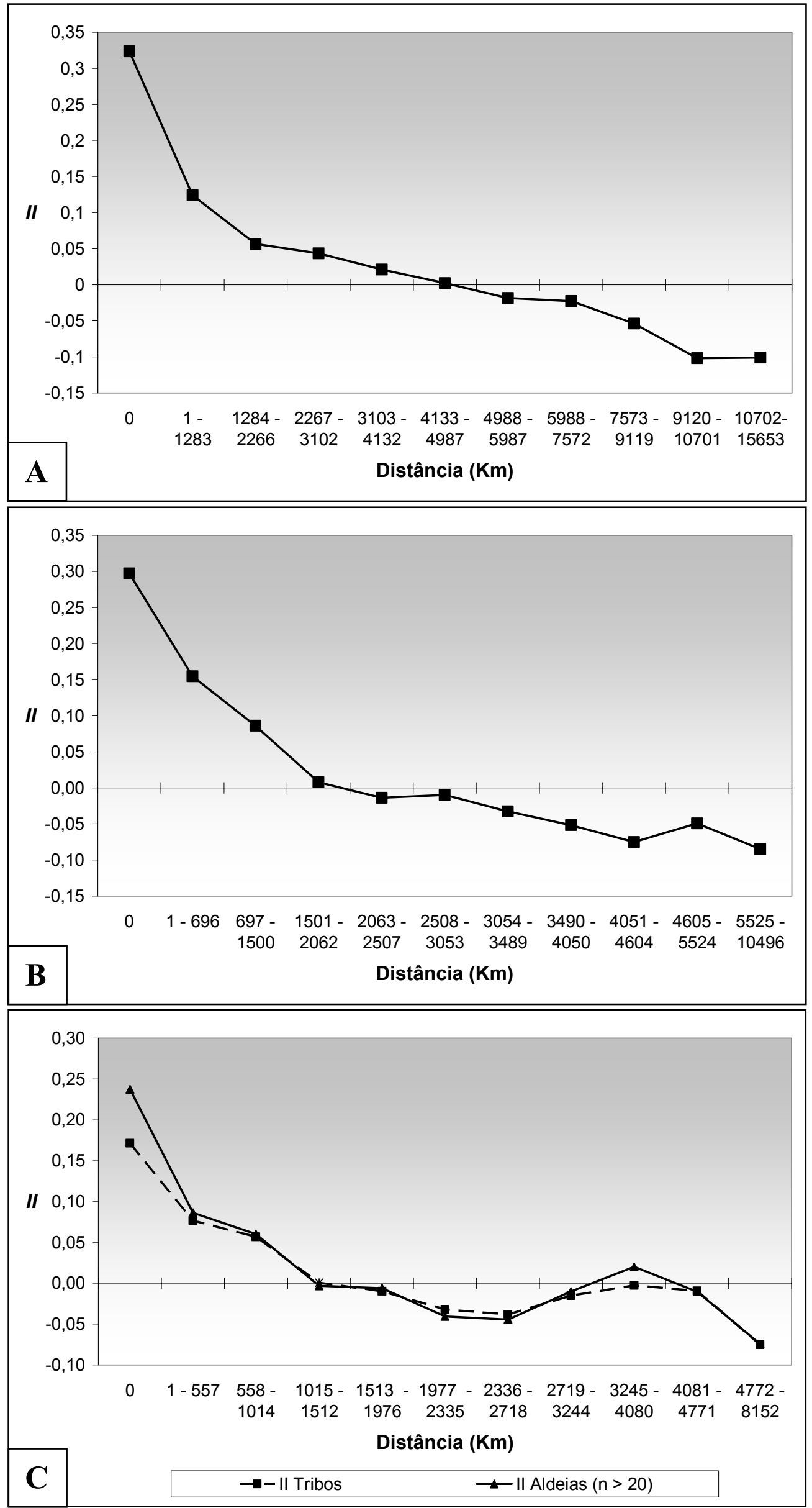
Figura 4 (página anterior). Análise de autocorrelação espacial realizada a partir de haplogrupos de mtDNA de indígenas (A) do continente americano, (B) da América do Norte e (C) da América do Sul. A) Correlograma construído a partir de 5522 indivíduos pertencentes a 99 amostras populacionais, sendo 48 (2847 indivíduos) da América do Norte e 51 (2675 indivíduos) da América do Sul. B) Correlograma construído a partir de 3498 indivíduos pertencentes a 94 amostras populacionais. C) Primeiro correlograma construído a partir de 3671 indivíduos de 92 aldeias e segundo a partir de 4503 indivíduos pertencentes a 96 tribos. Os limites dos intervalos de distância foram construídos de modo que cada um deles incorpore aproximadamente o mesmo número de pares de indivíduos. Os índices $I I$ estão dispostos sobre o valor médio do intervalo de distância, sendo que os quadrados ( $\bullet$ ) e triângulos $(\mathbf{\Lambda})$ indicam os índices diferentes de zero ao nível de significância de $1 \%(\mathrm{p}<0,01)$ enquanto que o asterisco $(*)$ representa índice não-significante $(\mathrm{p}>0,05)$.

Verifica-se que, houve grande coincidência nos correlogramas de ambas abordagens, sendo que as pequenas diferenças certamente decorrem do número de indivíduos considerados em cada uma delas: 3671 e 4503 indivíduos, respectivamente.

De modo geral, em todos os três correlogramas (Figura 4) os índices II partiram de valores elevados e positivos, apresentando declínio acentuado ao longo das três ou quatro primeiras classes de distâncias e declínio menos expressivo nas classes posteriores. Valores negativos são alcançados entre a quarta e a sétima classes de distâncias. Enquanto que o correlograma das Américas apresenta declínio de forma quase que perfeitamente linear (Figura 4a), os correlogramas da América do Norte (Figura 4b) e principalmente da América do Sul (Figura 4c) desviam ligeiramente deste padrão pela existência de leve incremento observável nas últimas classes de distâncias, após o qual ocorre novo declínio. Um único valor de II, na quarta classe de distâncias das tribos da América do Sul (Figura 4b), não se apresentou significante $(\mathrm{p}>0,05)$. Todos os correlogramas foram considerados significantes ao nível de 5\% quando o critério de Bonferroni foi empregado. 

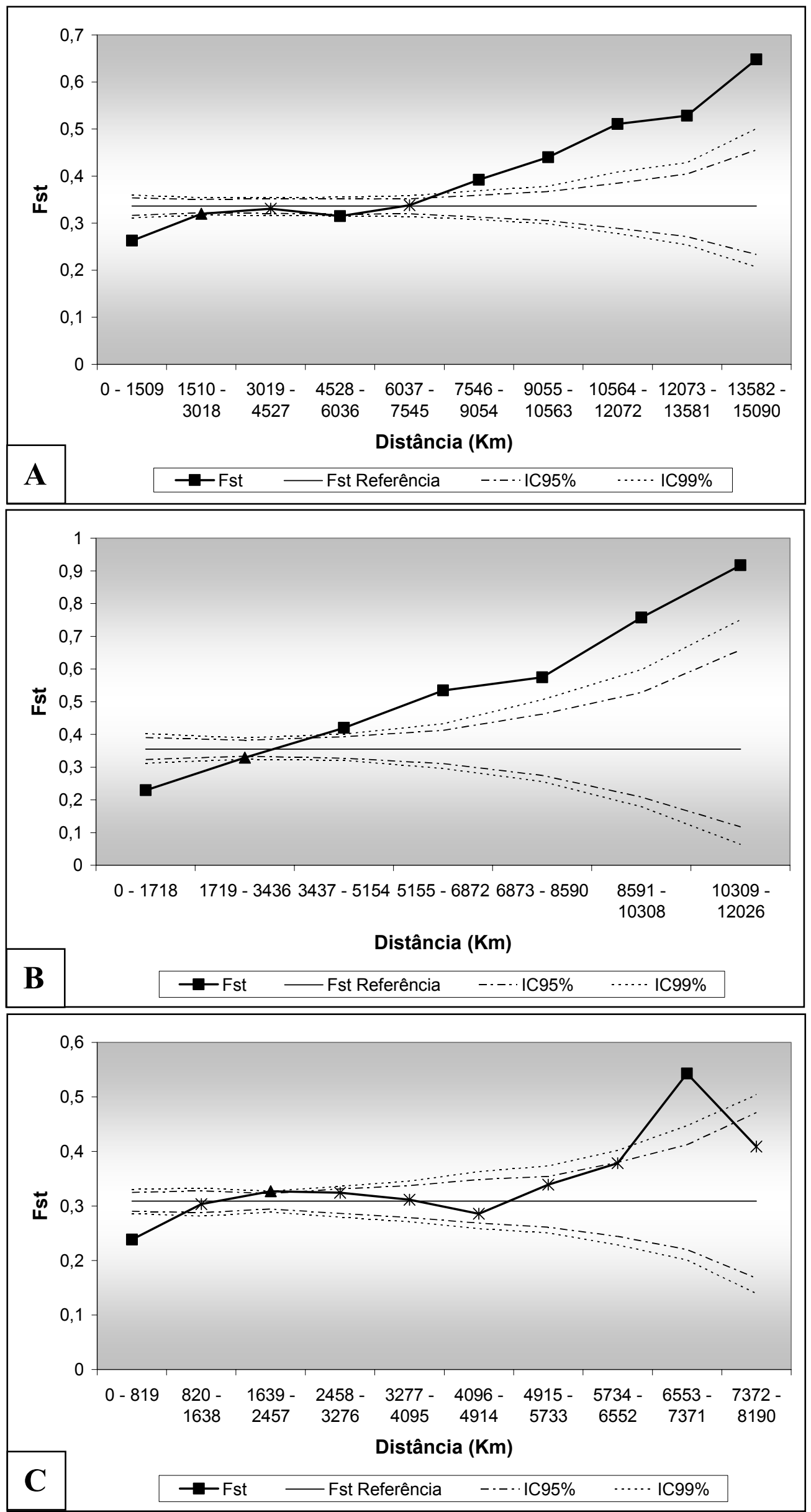
Figura 5. Distogramas obtidos a partir dos haplogrupos de mtDNA de populações indígenas (A) do continente americano, (B) da América do Norte e (C) da América do Sul. Foram utilizadas 227, 84 e 143 amostras populacionais, respectivamente. Os limites dos intervalos de distância foram construídos de modo que cada intervalo tenha mesma amplitude. Os valores médios de $F_{S T}$ estão dispostos sobre o valor médio do intervalo de distância, sendo que os quadrados $(\mathbf{\square})$ e triângulos $(\boldsymbol{\Delta})$ indicam os valores diferentes de zero aos níveis de significância de $1 \%(\mathrm{p}<0,01)$ e $5 \%(\mathrm{p}<0,05)$, respectivamente. Os asteriscos $(*)$ representam valores nãosignificantes $(p>0,05)$. Os intervalos de confiança de $95 \%$ e $99 \%$ foram obtidos independentemente a partir de 2 mil permutações.

Para análise de distogramas foram consideradas 227 das 245 amostras populacionais utilizadas na análise de autocorrelação espacial: por se tratar de análise baseada em freqüências alélicas de populações e não haver qualquer fator de correção para pequenos tamanhos amostrais, foi sugerido que populações com menos de dez indivíduos pudessem trazer algum viés à análise (Degen et al. 2001); desta forma, foram eliminadas as populações que apresentaram menos do que dez indivíduos portadores de haplogrupos nativo-americanos. Distogramas relativos ao continente americano (Figura 5a), à América do Norte (Figura 5b) e à América do Sul (Figura 5c), envolvendo respectivamente 227, 84 e 143 amostras populacionais, foram obtidos.

De modo geral, os três distogramas apresentam aumento contínuo das distâncias genéticas em função do aumento das distâncias geográficas que separam as populações, partindo de valores significantemente abaixo do esperado ao acaso nas primeiras classes de distâncias, passando por valores não significantes nas classes intermediárias, até atingir valores significantemente elevados entre as populações separadas por grandes distâncias geográficas. Este padrão é evidente principalmente nos distogramas das Américas (Figura 5a) e da América do Norte (Figura 5b), enquanto que no da América do Sul (Figura 5c), o valor de $F_{S T}$ relacionado à última classe de distâncias experimenta decréscimo de $24,71 \%$ em relação ao valor imediatamente anterior, tornando-se não significante. 


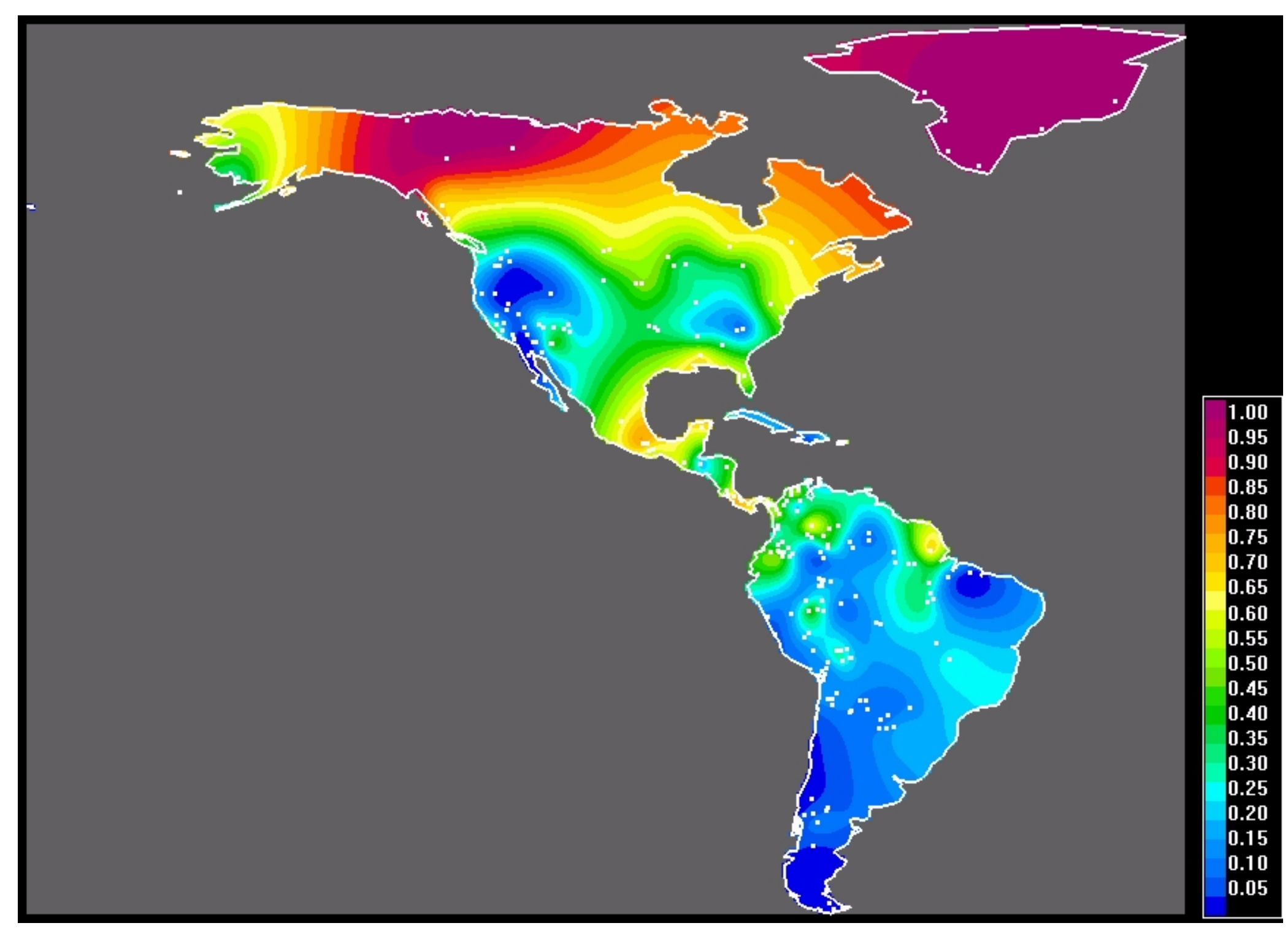

Figura 6. Mapa de freqüências do haplogrupo A em superfície interpolada pelo algoritmo ABOS. 


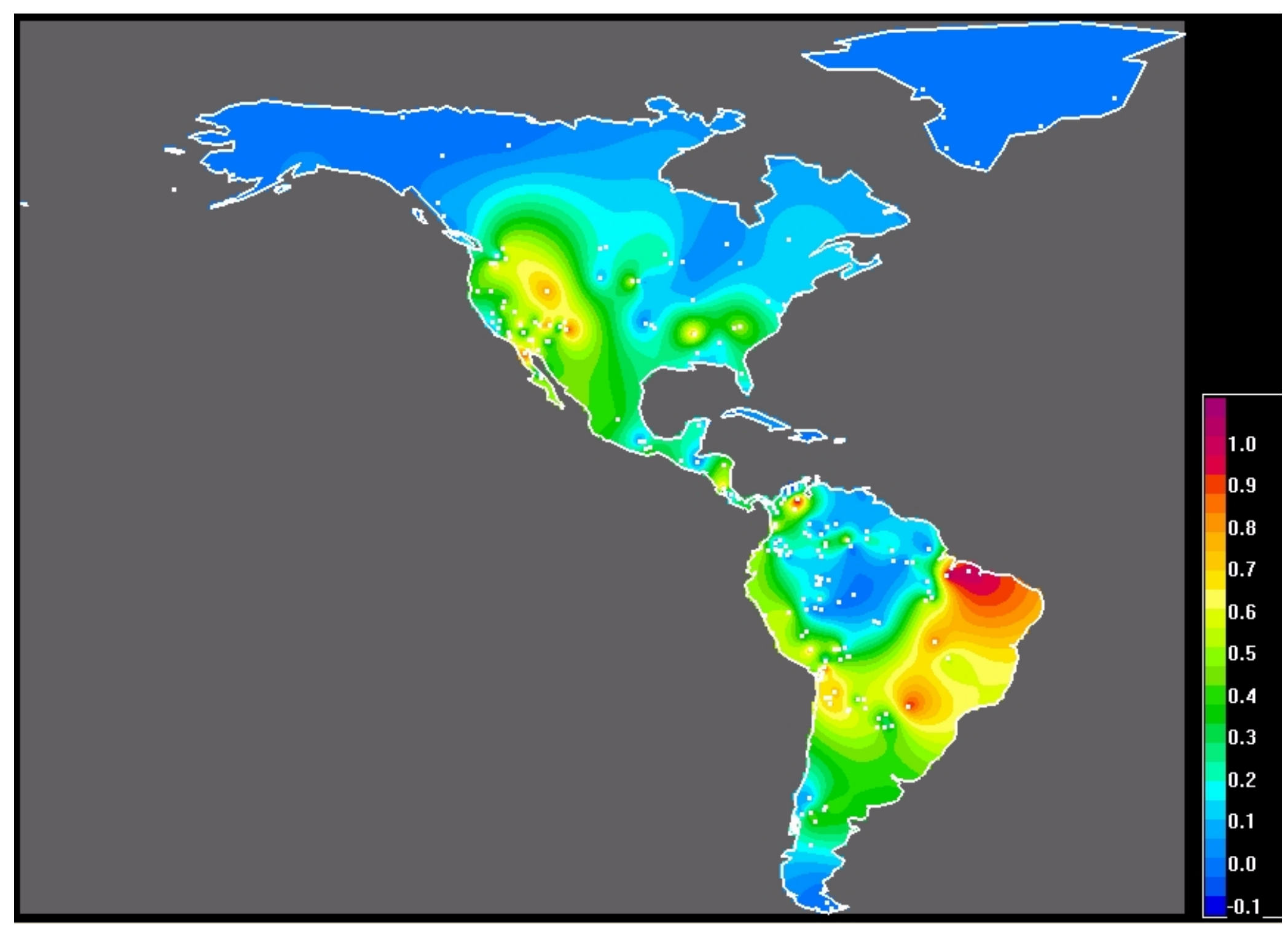

Figura 7. Mapa de freqüências do haplogrupo B em superfície interpolada pelo algoritmo ABOS. 


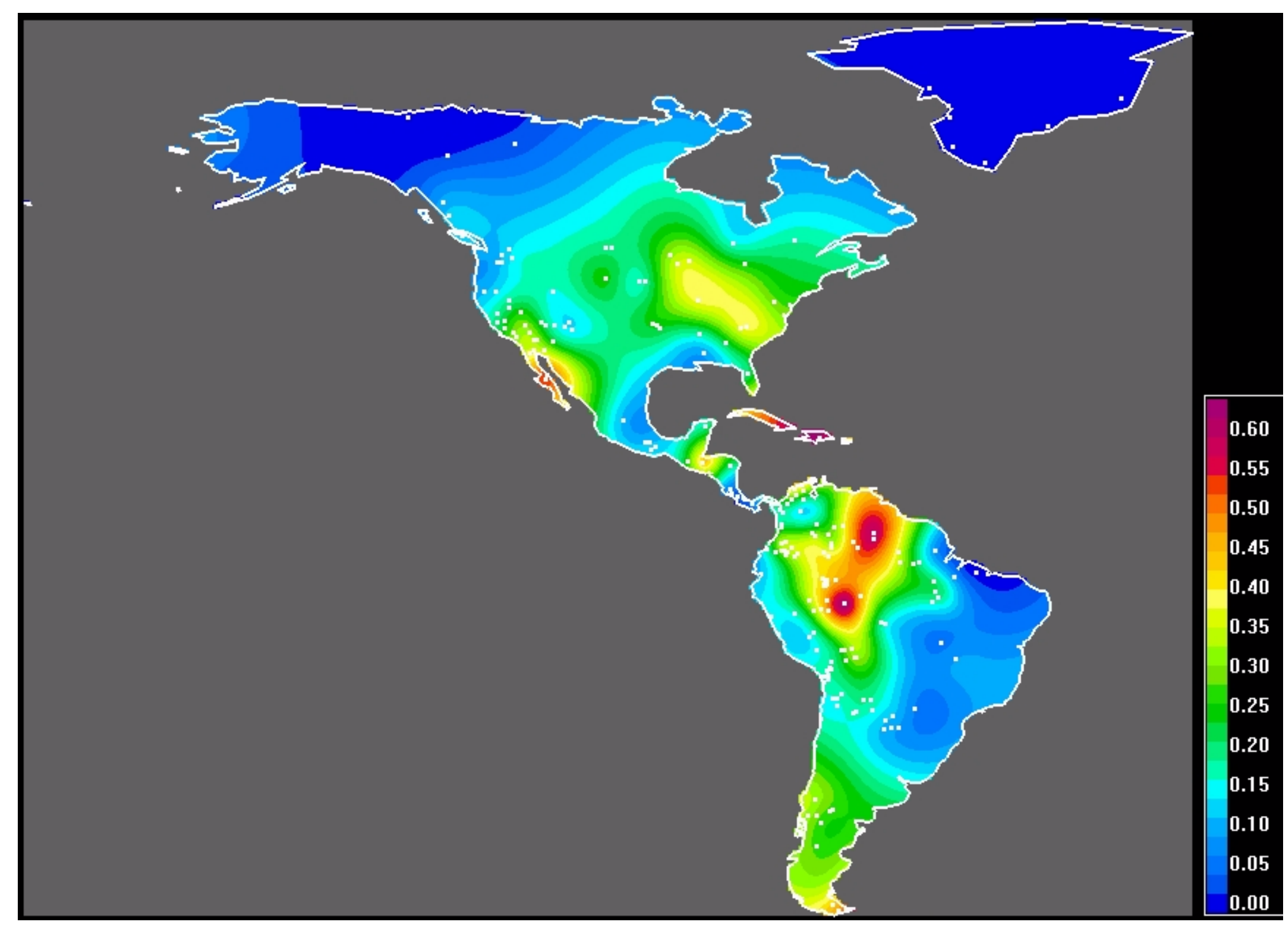

Figura 8. Mapa de freqüências do haplogrupo C em superfície interpolada pelo algoritmo ABOS. 


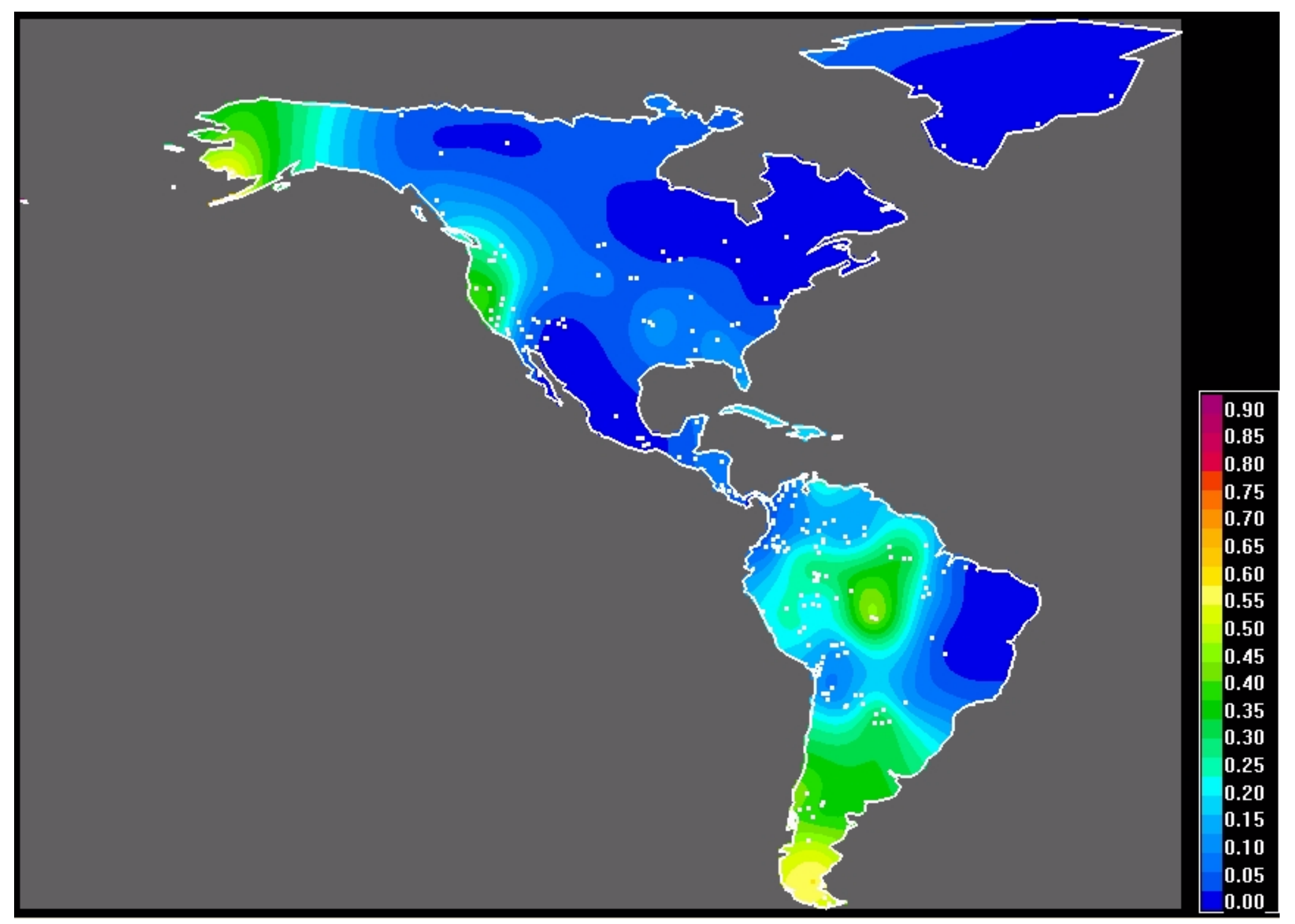

Figura 9. Mapa de freqüências do haplogrupo D em superfície interpolada pelo algoritmo ABOS. 
Visto que os correlogramas e distogramas evidenciaram a existência de padrão espacial significativo, nos quais os valores de $I I$ e $F_{S T}$ das primeiras classes de distâncias foram significantemente positivos e negativos, respectivamente, conclui-se que populações locais mais próximas no espaço tendem a apresentar os haplogrupos em freqüências mais semelhantes entre si do que em relação à variação total existente (Diniz-Filho 1998). Torna-se interessante, portanto, o mapeamento dos valores de freqüências dos quatro haplogrupos indígenas difundidos nas Américas, para se tentar visualizar o padrão espacial de distribuição dos mesmos. Mapas geográficos de freqüências de cada haplogrupo foram obtidos através da interpolação de freqüências nas localidades amostradas (Figuras 6-9). Para a construção dos mapas de todo o continente, foram utilizadas as mesmas 245 amostras de populações indígenas (Apêndice A) utilizadas na análise de autocorrelação espacial.

Uma vez que após o contato com os colonizadores europeus as populações habitantes do litoral do Brasil foram quase totalmente dizimadas, dominadas/assimiladas ou fugiram para o interior a fim de evitar contato com os colonizadores europeus, juntamente com as dificuldades atuais de coleta de material biológico indígena, é praticamente inviável a obtenção de mtDNA de populações indígenas do extremo leste do continente (regiões Nordeste, Sudeste e Sul do Brasil). Sendo assim, com o intuito de se obter definição melhor e mais robusta da distribuição dos haplogrupos indígenas na costa atlântica da América do Sul, mapas sul-americanos alternativos foram obtidos (Figura 10) com a incorporação de mtDNA proveniente de populações urbanas e afro-derivadas (de S159 a S192 - Apêndice A), as quais normalmente apresentam quantidade razoável de mtDNA de origem ameríndia introduzido pelo fluxo gênico e/ou assimilação de populações nativas que habitavam as respectivas redondezas. Desta forma, as freqüências relativas de cada haplogrupo (em relação apenas ao número de haplogrupos de origem nativo-americana da amostra) devem ser representativas da região na qual uma localidade se insere. 


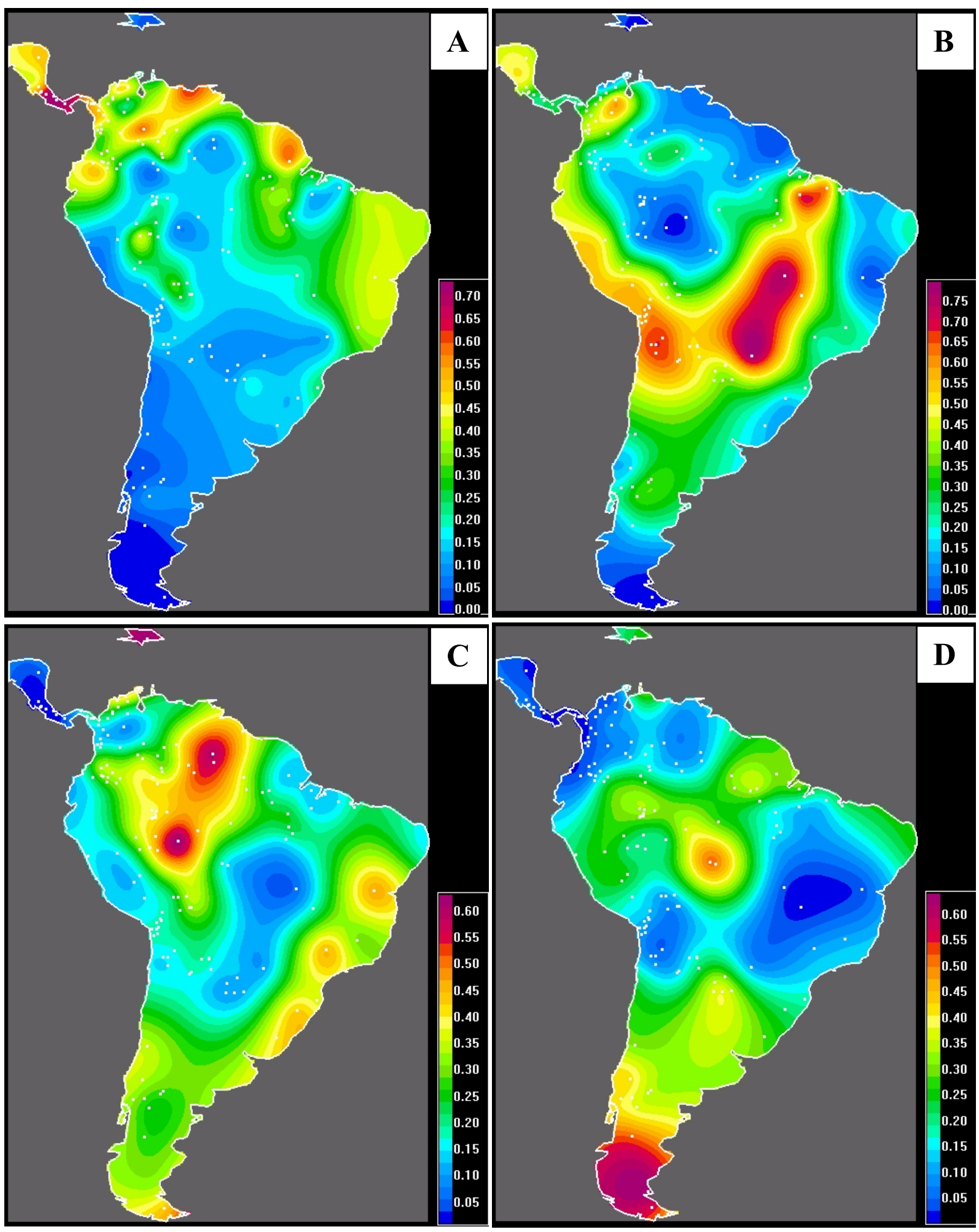

Figura 10. Mapas de freqüências dos haplogrupos de mtDNA nativo-americanos encontrados na América do Sul, em superfície interpolada pelo algoritmo ABOS: (A) haplogrupo A, (B) haplogrupo $\mathrm{B},(\mathrm{C})$ haplogrupo $\mathrm{C}$ e (D) haplogrupo D. Estes mapas diferem dos apresentados nas figuras anteriores pela inclusão de freqüências obtidas em populações afro-derivadas e urbanas. As cores incluídas nas legendas não equivalem às apresentadas nas figuras anteriores. 


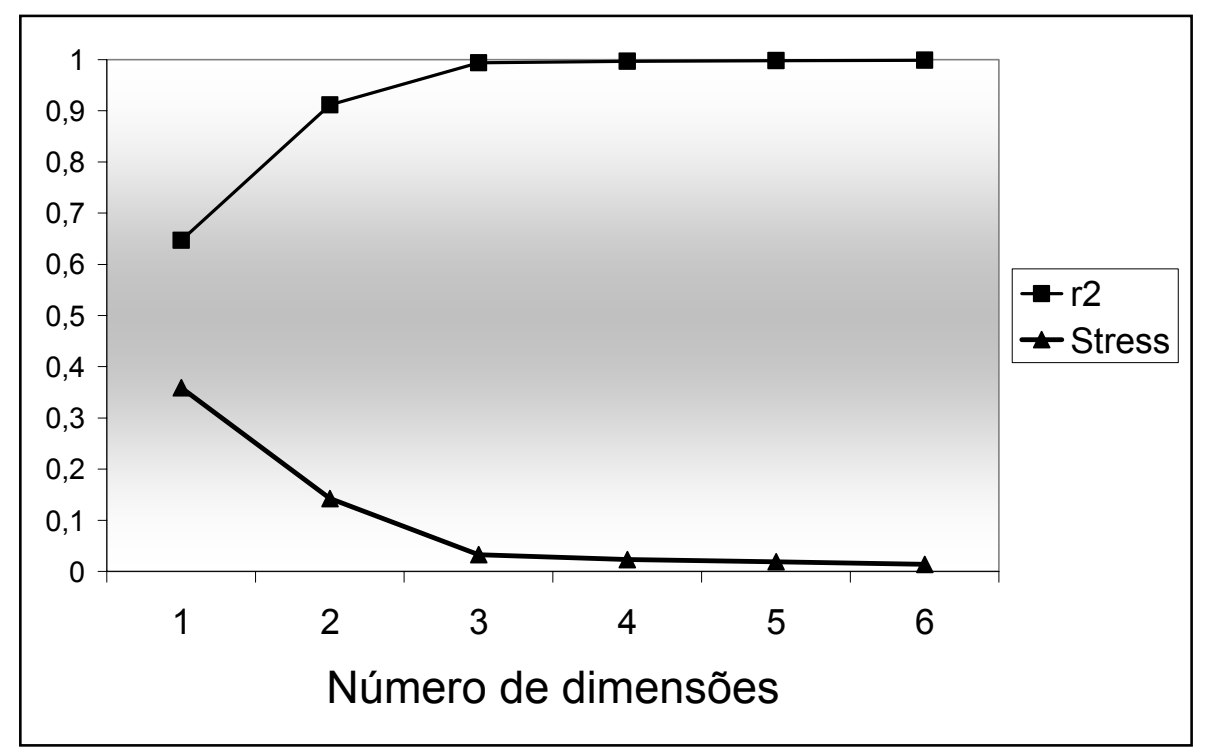

Figura 11. Análise multidimensional (NM-MDS). Gráfico indicando os valores dos índices de performance $\left(r^{2} \mathrm{e}\right.$ stress) em função do número de dimensões avaliadas, a partir das matrizes de distância entre 96 tribos sulamericanas. A matriz de distâncias genéticas de Reynolds foi obtida a partir das freqüências dos haplogrupos de mtDNA

Análise multidimensional (MDS) também foi empregada na análise dos dados de populações nativas da América do Sul (S001 a S155). Da mesma forma que na análise de autocorrelação espacial (AIDA), a limitação de no máximo cem amostras populacionais foi imposta pelo programa, o que fez com que o mesmo conjunto de tribos utilizado para os cálculos de AIDA (151 populações sul-americanas agrupadas em 96 tribos) fosse aqui empregado. A matriz de distâncias genéticas de Reynolds entre pares de populações foi obtida e submetida à análise de MDS. Dentre as soluções testadas, a mais adequada foi a de três dimensões (Figura 11). Portanto, as três coordenadas que definem a localização de cada uma das 96 populações no espaço tridimensional foram obtidas e interpoladas separadamente em mapas geográficos (Figura 12a-c), uma vez que a variação geográfica nos valores de cada coordenada poderia indicar as rotas migratórias seguidas pelos ancestrais dos indígenas contemporâneos (Salzano e Callegari-Jacques 1988). 

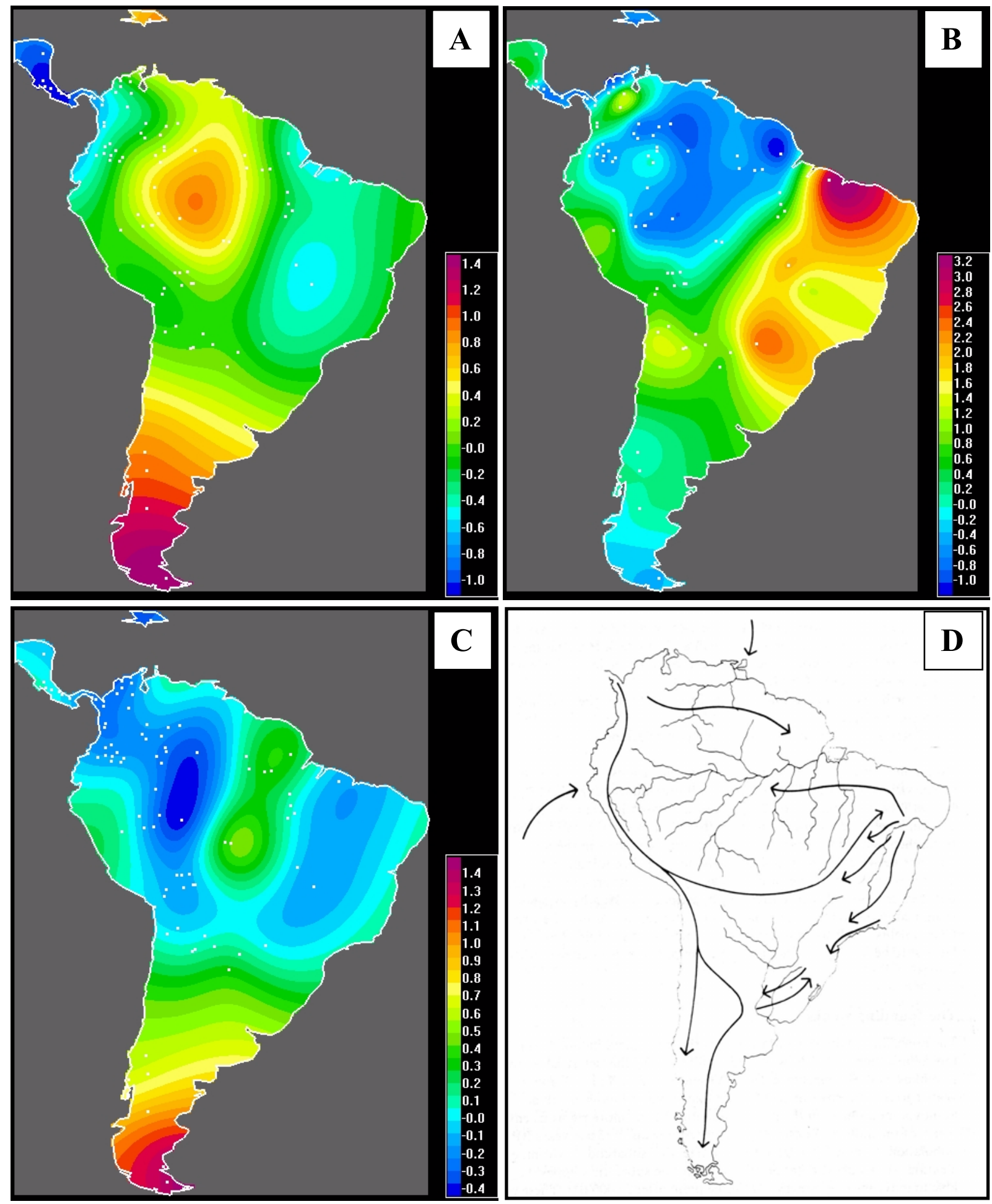

Figura 12. Representação gráfica dos valores das três dimensões obtidas na análise de NM-MDS, baseadas na distribuição dos haplogrupos de mtDNA nativo-americanos em 96 tribos da América do Sul, em superfície interpolada pelo algoritmo ABOS: (A) Primeira dimensão, (B) Segunda dimensão, (C) Terceira dimensão. A figura D consiste em mapa indicando as possíveis rotas seguidas pelos indígenas sul-americanos, inferidas a partir de dados arqueológicos (Schmitz 1983; Salzano e Callegari-Jacques 1988). 


\section{Discussão}

\subsection{Mistura inter-étnica}

Apenas $1(0,32 \%)$ dos 308 indivíduos estudados apresentou haplogrupo de origem nãoindígena (Tabela 2). Em estudo de marcadores clássicos no mesmo conjunto de populações aqui estudadas verificou-se em todas as tribos níveis de mistura bem inferiores a 5\% (Neel et al. 1980). A maioria das estimativas resultou em valores abaixo de $1 \%$ ou até mesmo nulos (Gershowitz e Neel 1978; Mohrenweiser et al. 1979; Salzano e Callegari-Jacques 1988; Callegari-Jacques e Salzano 1999). tendo os maiores valores ocorridos entre os Tikúna, variando de $1,1 \%$ (pela análise de imunoglobulinas) a 3,3\% (pela análise do grupo sangüíneo ABO) (Neel et al. 1980; Salzano e Callegari-Jacques 1988).

Já a inserção Alu YAP, ausente em populações indígenas pré-colombianas cuja presença é atribuída de imediato à mistura inter-étnica (Bianchi et al. 1997; Karafet et al. 1997), foi encontrada em 2 indivíduos (em dois haplótipos bastante divergentes) dentre 153 analisados das tribos Tikúna, Kaxináwa, Kanamarí e Baníwa, o que sugere a ocorrência de mistura mediada por homens de pelo menos 1,31\% (Wanderley-Santos et al. 2005). Enquanto que na África a freqüência desta inserção chega a alcançar 100\% em algumas populações, na Europa Oriental as freqüências não chegam a atingir 30\% (Quintana-Murci et al. 1999; Bravi et al. 2000; Forster et al. 2000; Malaspina et al. 2000). Visto que dados históricos e genéticos revelam que desde o início da colonização do Brasil o padrão de mistura inter-étnica relativamente comum envolvia relações entre homens portugueses e mulheres indígenas (e africanas) (Alves-Silva et al. 2000; Carvalho-Silva et al. 2001), o mais provável é que estes dois haplótipos $\mathrm{YAP}^{+}$sejam de origem européia. Sendo assim, haplótipos de origem européia 
que não portam a inserção Alu YAP também devem estar presentes na amostra, convertendo a estimativa de mistura inter-étnica masculina mencionada $(1,31 \%)$ em clara sub-estimativa.

Portanto, os pequenos níveis de mistura inter-étnica observados nas sete tribos aqui estudadas indicam que elas estão entre as que conseguiram preservar um pouco mais de sua identidade genética devido ao difícil acesso à Floresta Amazônica. Enquanto que a mistura feminina é praticamente desprezível, a mistura masculina é pouco mais significativa e provavelmente, embasado em dados históricos e genéticos (Carvajal-Carmona et al. 2000; Mesa et al. 2000; Bortolini et al. 2002), mediada por homens europeus.

Baseado nos dados de mtDNA aqui obtidos, inferências quanto à significância deste resultado podem ser realizadas: a partir da equação binomial, pode-se estimar que a probabilidade deste achado, isto é, de se encontrar 1 haplogrupo não-indígena em amostra composta por 308 indivíduos, é inferior a 1\% quando se assume nível de mistura maior do que $2,08 \%$ na população da qual a amostra se originou e inferior a $5 \%$ quando se assume mistura maior do que 1,45\% (Tabela 13). Portanto, ao nível de significância de 0,05 , a presente amostra permite descartar ocorrência de mistura superior a $1,5 \%$ na população da qual as amostras se originaram.

\subsection{Diversidade intra-populacional}

De modo geral, as populações se dividiram em três grupos quanto à diversidade genética intra-populacional (Tabela 2). Três aldeias apresentaram diversidade entre $56 \%$ e $58 \%$; entre elas encontra-se a aldeia Paredão, que já vinha mostrando os menores valores de diversidade pela análise de STRs autossômicos (Mendes-Junior 2001; Wanderley-Santos 2001) e PSAs (Luizon 2003). Metade das aldeias apresentou diversidade entre 61\% e 69\%. Por fim, quatro 
aldeias (três delas da tribo Tikúna) apresentaram diversidade entre $70 \%$ e $77 \%$. Apenas a aldeia Sete Estrelas não se enquadrou em nenhum dos três grupos, apresentando diversidade de $36,26 \%$ (Tabela 2).

Tabela 13 - Probabilidade de obtenção da presente amostra (formada por 1 haplogrupo não-indígena e 307 haplogrupos indígenas) a partir de populações com níveis hipotéticos de mistura inter-étnica variando de $0,1 \%$ a $2,1 \%$. Os valores significantes aos níveis de $5 \%$ e $1 \%$ estão destacados em itálico e negrito, respectivamente.

\begin{tabular}{cc}
\hline Suposta mistura étnica na população (\%) & Probabilidade de obtenção da amostra \\
\hline 0,10 & 0,2265 \\
0,30 & 0,3674 \\
0,50 & 0,3305 \\
0,70 & 0,2495 \\
0,90 & 0,1727 \\
1,10 & 0,1136 \\
1,30 & 0,0721 \\
1,45 & 0,0504 \\
1,46 & 0,0492 \\
1,50 & 0,0446 \\
1,70 & 0,0271 \\
1,90 & 0,0162 \\
2,08 & 0,0101 \\
2,09 & $\mathbf{0 , 0 0 9 8}$ \\
2,10 & $\mathbf{0 , 0 0 9 6}$ \\
\hline
\end{tabular}

Microssatélites autossômicos (Mendes-Junior 2001) e ligados ao cromossomo Y (Wanderley-Santos 2001) e a re-análise de dados de marcadores clássicos (Mendes-Junior 2001) mostraram diversidade bem superior em aldeias Tikúna em relação a aldeias de outras tribos. No presente estudo foi verificado por meio de teste não-paramétrico (Wilcoxon-MannWhitney) que a diversidade das aldeias Tikúna não é significantemente maior do que a diversidade das aldeias Pano $(p=0,0707)$, embora maior média de número de haplogrupos e de diversidade genética tenham sido observadas nas primeiras. A maior diversidade nas 
aldeias Tikúna é esperada, visto que esta tribo apresentava na época da coleta cerca de 11 mil indivíduos e existe estímulo à exogamia intra-tribal (Mestriner et al. 1980; Salzano et al. 1980) enquanto que cada uma das tribos Pano aqui estudadas apresentavam entre 400 e 2.000 membros (700 Katukina, 2.000 Kaxináwa, 400 Marúbo e 410 Yaminawa) (Mestriner et al. 1980). Sendo assim, os efeitos da deriva genética são teoricamente mais intensos nestas últimas tribos, o que levaria à perda de haplogrupos e de diversidade genética. Visto que na época da coleta existiam cerca de 18 mil indivíduos Pano (incluindo outras tribos que não foram compreendidas pelo presente estudo), se a homogeneidade deste grupo fosse equiparável à dos Tikúna seria esperado níveis de diversidade nas aldeias Pano equivalentes ou até mesmo superiores aos observados nas aldeias Tikúna, devido a uma menor influência da deriva genética nas aldeias Pano.

A partir da diversidade intra-populacional é possível se fazer inferências mais aprofundadas sobre a homo/heterogeneidade das populações. Quanto maior for a homogeneidade de uma tribo, isto é, quanto mais semelhantes forem as aldeias pertencentes a tal tribo, menor será o desvio $\left(d_{S T}\right)$ entre os valores médios de diversidade intra-populacional das aldeias e os valores da tribo como um todo (o que representa justamente a base de uma maneira clássica (Nei 1987) de se estimar o parâmetro $F_{S T}$, o qual será posteriormente abordado). Estes desvios constituem um primeiro indicativo de que os Tikúna constituem tribo homogênea $\left(d_{S T}=0,0286\right)$, enquanto que os Pano seriam mais estruturados geneticamente $\left(d_{S T}=0,1162\right)$, isto é, suas aldeias apresentam número de haplogrupos e diversidade intra-populacional menores do que seria esperado caso constituíssem uma população panmítica. 


\subsection{Diversidade intra-tribal e isolamento dos Tikúna}

Contrastando com a afirmativa do parágrafo imediatamente anterior, no qual foi dito que os Tikúna seriam homogêneos, foi identificada heterogeneidade significante entre as aldeias desta tribo $\left(F_{S T}=0,0481\right)$. Dois aspectos precisam ser considerados a este respeito. Primeiro, um resultado estatisticamente significante não representa automaticamente significância biológica (Callegari-Jacques 2003). Enquanto que a significância estatística serve para medir o grau de confiança de que uma diferença obtida seja espúria, sendo altamente dependente do tamanho amostral e da magnitude da diferença, ela de modo algum indica se a diferença é pequena, moderada ou grande (Callegari-Jacques 2003). Neste caso, observa-se que a diferença entre as aldeias Tikúna é significante (confiável), porém menor do que entre aldeias de outras tribos com quatro ou mais aldeias analisadas (Tabela 14).

Tabela $14-F_{S T}$ e teste exato de diferenciação populacional, baseados nas freqüências dos haplogrupos de mtDNA, em tribos sul-americanas com três ou mais aldeias analisadas (Apêndice A). Os valores significantes aos níveis de $5 \%$ e $1 \%$ estão destacados em itálico e negrito, respectivamente.

\begin{tabular}{|c|c|c|}
\hline Conjunto de amostras ${ }^{I}$ & $F_{S T}($ probabilidade $)$ & $\begin{array}{c}\text { Probabilidade do teste exato de } \\
\text { diferenciação populacional }\end{array}$ \\
\hline 3 aldeias Atacameno (S027-S029) & $-0,0048(0,4735 \pm 0,0026)$ & $0,5054 \pm 0,0102$ \\
\hline 3 aldeias Toba (S099-S101) & $0,0034(0,3705 \pm 0,0030)$ & $0,4130 \pm 0,0087$ \\
\hline 3 aldeias Pehuenche (S141-S143) & $0,0083(0,1960 \pm 0,0022)$ & $0,5864 \pm 0,0195$ \\
\hline 8 aldeias Tikúna (S067-S074) & $0,0481(0,0058 \pm 0,0004)$ & $0,0059 \pm 0,0029$ \\
\hline 6 aldeias Quechua (S123-S128) & $0,0548(0,0004 \pm 0,0001)$ & $0,0003 \pm 0,0003$ \\
\hline 6 aldeias Mapuche (S135-S140) & $0,0633(0,0000 \pm 0,0000)$ & $0,0000 \pm \mathbf{0 , 0 0 0 0}$ \\
\hline 10 aldeias Aymara (S111-S120) & $0,0643(0,0001 \pm 0,0001)$ & $0,0014 \pm 0,0010$ \\
\hline 4 aldeias Mataco (S094-S097) & $0,0644(0,0045 \pm 0,0009)$ & $0,0007 \pm 0,0003$ \\
\hline 3 aldeias Embera (S034-S036) & $0,1539(0,0008 \pm 0,0002)$ & $0,0000 \pm 0,0000$ \\
\hline 6 aldeias Pano (S102-S106, S108) & $0,1985(0,0000 \pm 0,0000)$ & $0,0000 \pm 0,0000$ \\
\hline 4 aldeias Yanomama (S006-S009) & $0,2298(0,0000 \pm 0,0000)$ & $0,0000 \pm 0,0000$ \\
\hline
\end{tabular}

\footnotetext{
${ }^{1}$ Os códigos entre parênteses referem-se às populações presentes no Apêndice A.
} 
Segundo, analisando detalhadamente as aldeias Tikúna através da estimativa de $F_{S T}$ população-específicos $\left(F_{S T(k)}\right)$, foi possível identificar a presença de duas aldeias (Belém e Vendaval) altamente divergentes das demais (Tabela 6), porém geneticamente quase idênticas entre si (Tabelas 4 e 5). A exclusão destas duas aldeias conduz a $F_{S T}$ não-significante e de magnitude $67,57 \%$ menor do que o valor supra-citado $\left(F_{S T}=0,0156 ; p=0,1754\right)$. Dentre as seis diferenças significantes entre pares de aldeias Tikúna (Tabelas 4 e 5), a maioria inclui a aldeia Belém ou Vendaval. Excluindo tais aldeias, tem-se que das 15 comparações entre os seis pares de aldeias restantes apenas $2(13,33 \%)$, pela análise de $F_{S T}$, e $1(6,67 \%)$, pelo teste exato, se apresentaram significantes ao nível de 5\%. Aplicando-se a correção de Bonferroni para múltiplas comparações, nenhuma delas permanece significante ao nível mencionado. Portanto, conclui-se que pelo menos as seis aldeias restantes são realmente homogêneas enquanto que as aldeias Belém e Vendaval formam um grupo homogêneo à parte. Este padrão é ainda corroborado pela representação bi-dimensional da matriz de distâncias genéticas de Reynolds, na qual Belém e Vendaval se inserem na porção mais distante do quadrante inferior direito enquanto que as seis aldeias Tikúna restantes se dispõem em posições mais centrais no gráfico (Figura 2c).

É possível que este cenário esteja retratando o início de um processo de diferenciação destas duas aldeias em relação às demais. Alguns dados demográficos (Salzano et al. 1980), embora disponíveis apenas com relação a cinco das oito aldeias aqui estudadas, permitem visualizar a dicotomia entre Belém e Vendaval em relação às demais. Enquanto que em Belém (73\%) e Vendaval (76\%) a maior parte dos casamentos envolvem dois membros da mesma tribo, Nova Itália, Umariaçu e Campo Alegre apresentam apenas de 5\% a 16\% de seus casamentos organizados desta forma. Os adultos das duas primeiras nasceram em média entre 7 e 12 quilômetros da aldeia em que residem, sendo que 84\%-88\% deles nasceram na mesma; por outro lado, os adultos das três últimas nasceram em média entre 32 e 147 quilômetros da 
aldeia em que vivem, sendo que apenas $15 \%$-39\% deles nasceram na mesma (Salzano et al. 1980). Em resumo, Belém e Vendaval apresentam menor tendência à exogamia do que as demais aldeias, embora esta característica ainda esteja presente.

Este processo de diferenciação, no entanto, não é observável pela re-análise de marcadores clássicos $\left(F_{S T}=0,003 ; p>0,05\right)$ (Mendes-Junior 2001), pela análise de inserções $\operatorname{Alu}\left(F_{S T}=0,006 ; p>0,05\right)\left(\right.$ Oliveira 1999) e microssatélites autossômicos $\left(F_{S T}=0,0073\right.$; $p<0,01$ ) (Mendes-Junior 2001), pelos quais foi constatada forte homogeneidade no conjunto formado entre as quatro aldeias Tikúna estudadas (Belém, Vendaval, Feijoal e Umariaçu). Microssatélites ligados ao cromossomo Y $\left(F_{S T}=0,0272 ; p>0,05\right)$ (Wanderley-Santos et al. 2005), marcadores que refletem a história populacional masculina e PSAs $\left(F_{S T}=0,026\right.$; $p<0,01$ ) (Luizon 2003), marcadores que tiveram a informatividade quanto à aplicabilidade em estudos micro-evolutivos questionada, também não corroboram tal diferenciação de Belém e Vendaval.

Deste modo, a única explicação plausível é de que tal diferenciação por deriva genética esteja ocorrendo de maneira muito mais intensa entre as linhagens femininas e, embora a tendência à exogamia seja reduzida nestas duas aldeias, o fluxo gênico mediado por homens esteja ocorrendo em intensidade suficiente para homogeneizar até mesmo o material genético autossômico, que já é por natureza menos afetado pelos efeitos da deriva do que o mtDNA e o cromossomo Y. No entanto, diante dos indícios de que se trata de tribo com clãs exogâmicos patrilineares (Salzano et al. 1980; Simões 1980), que por sua vez acaba resultando em patrilocalidade, seria esperado que os homens migrassem menos do que as mulheres. Portanto, os dados genéticos parecem ser, a princípio, incompatíveis com os dados sócio-demográficos. Não se pode, contudo, descartar a hipótese de que o padrão de organização social supracitado tenha sido desfigurado pela explosão demográfica dos Tikúna que vinha ocorrendo desde as décadas anteriores à coleta (1976), aliada ao movimento 
religioso denominado "Holy Cross", iniciado em 1972 nesta região e que transformou algumas aldeias situadas ao longo do Rio Solimões em verdadeiros pólos de atração para os quais muitas famílias se direcionaram (Salzano et al. 1980). Tal movimento alterou dramaticamente o tamanho e a composição de muitas aldeias Tikúna (Salzano et al. 1980), o que pode estar se refletindo de maneira significativa nos dados genéticos apresentados.

As ferramentas empregadas para se testar o isolamento tribal dos Tikúna mostraram (a) maiores diferenças entre os 64 pares de aldeias que incluem uma aldeia Tikúna e uma de outra tribo do que entre os 13 pares de aldeias de tribos distintas que não incluem aldeias Tikúna (Tabelas 4 e 5) e (b) que as tribos Marúbo e Tikúna são divergentes entre si, e altamente divergentes com relação às demais aldeias (Tabela 7 e Figura 2d). Estes resultados sugerem relativo isolamento dos Tikúna, mas a disposição das aldeias em análise bi-dimensional não permitem descartar eventual mistura inter-tribal feminina (Figura 2d). Para descartar esta hipótese é ainda necessário o estudo de região do mtDNA que apresente maior variabilidade de seqüência, como as regiões hipervariáveis, que permitirá identificar se os haplogrupos compartilhados entre as aldeias Tikúna e as aldeias que se apresentaram mais próximas a elas são realmente semelhantes ou não.

\subsection{Diversidade intra-tribal dos Pano}

Devido à homogeneidade lingüística e cultural (Mohrenweiser et al. 1979; Simões 1980; Erikson 1998) entre as populações deste subgrupo lingüístico, as tribos que falam tal língua são normalmente consideradas como integrantes da "tribo" Pano (Mohrenweiser et al. 1979; Simões 1980). Apesar destas características, a homogeneidade entre aldeias desta tribo ainda não foi geneticamente examinada. 
De imediato já se observa que o padrão de diferenciação populacional neste grupo é bastante atípico: enquanto que as duas aldeias Kaxináwa se mostraram extremamente homogêneas, as duas aldeias Katukina apresentaram o maior valor de $F_{S T}\left(F_{S T}=0,4690\right.$; $p=0,0000)$ entre os 120 pares de aldeias analisadas no presente estudo (Tabela 4). Esta grande homogeneidade das aldeias Kaxináwa era esperada não só pela afiliação tribal, mas também pelo fato de que estão separadas por distância insignificante, sendo que habitantes de uma possuem parentes na outra (Salzano e Jacques 1979). Todos os outros conjuntos de marcadores previamente analisados (marcadores clássicos, microssatélites autossômicos e PSAs) em ambas aldeias Kaxináwa exibiram valores de $F_{S T}$ não-significantes e de magnitude muito próxima de zero, sendo a maioria deles até mesmo negativa (Mohrenweiser et al. 1979; Mendes-Junior 2001; Wanderley-Santos 2001; Luizon 2003). Por outro lado, além do fato de as duas aldeias Katukina estarem separadas por cerca de 135 quilômetros, Morada Nova é na realidade uma aldeia formada recentemente pela mistura de indivíduos provenientes de três tribos Pano (Katukina, Kaxináwa e Yaminawa) (Mohrenweiser et al. 1979; Salzano e Jacques 1979).

Maior proporção de pares de aldeias significantemente distintas foi observada entre aldeias Pano do que entre aldeias de tribos distintas (Tabelas 4 e 5). Com relação ao conjunto formado por todas as seis aldeias Pano, teste exato de diferenciação haplotípica e análise de $F_{S T}$ mostraram diferenças altamente significantes (Tabela 3 ), sendo que a magnitude do $F_{S T}$ foi superior à dos valores obtidos na comparação de todas as 16 aldeias ou de todas as sete tribos (Tabela 3), bem como à de todas as tribos sul-americanas que tiveram mtDNA analisado (Tabela 14), com exceção dos Yanomama.

A análise de $F_{S T}$ população-específico (Tabela 6), empregada justamente para examinar este padrão, mostrou que o menor dos valores observados ainda é elevado $\left(F_{S T(k)}=0,0879\right.$, em Cana Brava). Até mesmo entre as aldeias Yanomama (S006 - S009), as 
quais tiveram o maior $F_{S T}$ entre tribos sul-americanas, não foram observados muitos valores de $F_{S T(k)}$ tão elevados, sendo que um único valor foi realmente alto $\left(F_{S T(k)}=0,4945\right.$ na aldeia S009) enquanto que os três valores de $F_{S T(k)}$ restantes variaram de $-0,0111$ a 0,0637 . É preciso retirar metade das aldeias Pano para que as três menos divergentes constituam grupo homogêneo $\left(F_{S T}=0,0195 ; p=0,2743\right)$. Ao contrário do observado nos Tikúna, as três outras aldeias mais divergentes resultam em grupo relativamente heterogêneo, sendo a heterogeneidade significante pelo teste exato de diferenciação populacional $(p=0,0237)$ e comparativamente elevada (Tabela 14), porém não-significante, pela análise de $F_{S T}$ $\left(F_{S T}=0,0798 ; p=0,0995\right)$. Neste grupo, a aldeia Sete Estrelas apresenta altos valores de $F_{S T}$ nas comparações em relação às outras duas, sendo significante em relação a Yaminawa (Tabelas 4 e 5), o que sugere que deveria até mesmo ser considerada um terceiro grupo à parte. Esta heterogeneidade é condizente com a representação bi-dimensional (Figura 2c) da matriz de distâncias genéticas de Reynolds, na qual Sete Estrelas se isola das demais no quadrante inferior esquerdo, Yaminawa e Paredão se inserem no quadrante superior esquerdo e Morada Nova e Vida Nova no quadrante superior direito. Cana Brava, a aldeia menos diferenciada em relação às demais, se insere no centro da parte superior do gráfico, em posição mais próxima à outra aldeia Kaxináwa (Paredão) do que das outras aldeias Pano.

O cenário retratado nos parágrafos anteriores é corroborado pelas análises em que as aldeias foram agrupadas de acordo com a afiliação tribal (Tabela 7 e Figura 2d). Exceto quando se assume nível de significância de 5\% no teste exato de diferenciação populacional, mais diferenças significantes são observadas entre as tribos Pano do que entre tribos de línguas distintas. Desconsiderando-se a significância e avaliando-se apenas a magnitude dos valores de $F_{S T}$ (Tabela 7), observa-se que a média dos 6 valores de $F_{S T}$ calculados entre pares de tribos Pano $\left(F_{S T}\right.$ médio $\left.=0,0944\right)$ é $45,45 \%$ maior que a média dos 15 valores de $F_{S T}$ entre 
tribos de língua distintas $\left(F_{S T}\right.$ médio $\left.=0,0649\right)$, o que se reflete na representação gráfica das distâncias genéticas (Figura 2d).

Todas as presentes análises revelaram níveis de heterogeneidade entre populações Pano equivalentes ou até mesmo superiores aos observados entre populações de afiliação lingüística distintos. Conclui-se, portanto, que a homogeneidade lingüística e cultural dos Pano não se reflete na estrutura genética deste grupo. Apesar da origem comum recente (Salzano e Jacques 1979), o fluxo gênico entre as aldeias Pano simplesmente não estaria sendo intenso o suficiente para manter a homogeneidade genética inicial. Alternativamente pode-se propor um cenário sexo-específico, no qual, baseado em indícios de que a maioria destas populações se organizam socialmente de forma matrilinear (Mohrenweiser et al. 1979), o que acaba normalmente resultando em uma sociedade matrilocal, o fluxo gênico existente entre tais populações estaria sendo mediado quase que exclusivamente por homens. Neste caso as mulheres permaneceriam fixas em suas aldeias nativas e, visto que o mtDNA apresenta alta susceptibilidade aos efeitos da deriva genética, já estaria refletindo este fenômeno de diferenciação populacional. Para se confirmar esta hipótese torna-se necessário pelo menos o estudo de variabilidade do cromossomo Y nestas populações.

\subsection{Variabilidade genética no centro-oeste da Amazônia brasileira}

A variabilidade genética de populações indígenas é organizada de forma complexa sendo que os dois fatores que mais exercem influência sobre a mesma é a variação lingüística e geográfica (Fagundes et al. 2002). É de grande interesse distinguir os efeitos exercidos pela geografia daqueles exercidos pela língua na variabilidade genética. De acordo com o modelo de isolamento-por-distância (IBD), é esperado que a diferenciação genética em loci neutros 
aumente com a distância genética (Wright 1943; Dupanloup et al. 2000). Embora o modelo IBD normalmente se ajuste a migrações de curta distância entre populações vizinhas, a correlação entre distâncias genéticas e geográficas tem sido encontrada na maioria das análises até mesmo em escalas continental e mundial (Cavalli-Sforza et al. 1994; Dupanloup et al. 2000). Por outro lado, nestas mesmas escalas geográficas, inúmeros estudos também revelaram forte correlação entre afiliação lingüística e diferenciação genética (Greenberg et al. 1986; Dupanloup et al. 2000). Análise de variância molecular, correlação de Spearman entre distâncias genéticas e geográficas e análise de autocorrelação espacial foram as ferramentas utilizadas na tentativa de se identificar eventual influência geográfica e/ou lingüística no padrão de distribuição da variabilidade genética dos haplogrupos de mtDNA na área abrangida pelo presente estudo.

A análise de variância molecular evidencia que a maior parte da variabilidade genética (87\% - 90\%), independentemente da estrutura genética testada, se encontra definitivamente dentro das aldeias indígenas (Tabela 8), o que é esperado por se tratar de marcadores genéticos que se reduzem a quatro haplogrupos amplamente difundidos por toda a América. Desta forma, quantidade de variância reduzida porém significante pode ser atribuída a diferenças entre aldeias dentro de mesmo grupo. Não houve variância entre os estoques lingüísticos $(0,01 \%)$ e apenas pequena variância, não-significante, entre as línguas faladas pelas tribos $(2,50 \%)$. Desta forma conclui-se que os mesmos haplogrupos estão presentes em freqüências equivalentes em todos os grupos lingüísticos, sendo que nesta região geográfica a divisão por afiliação lingüística não se reflete na variação do mtDNA. O componente da variância entre grupos $(3,97 \%)$ ainda não se torna significante quando a afiliação tribal é encarada como critério de agrupamento, sendo que a maior parte da variância entre populações ocorre justamente entre aldeias de mesma tribo. Este resultado é totalmente condizente com os resultados anteriores de heterogeneidade no nível infra-tribal. Quando esta 
heterogeneidade entre aldeias é completamente incorporada à estrutura hierárquica, a variância entre grupos quase triplica (11,71\%), passando a ser altamente significante. Embora este seja um indicativo mais forte ainda de que aldeias de mesma tribo já estão se diferenciando, este achado em especial deve ser considerado com cautela, uma vez que é esperado que o aumento no número de grupos resulte em aumento do $F_{C T}$ (Dupanloup et al. 2002).

Visto que a afiliação lingüística não é fator responsável pela distribuição da variabilidade dos haplogrupos de mtDNA, aumenta-se a probabilidade de influência da geografia na variabilidade genética. Enquanto que na área ocupada pelas aldeias Tikúna a correlação entre distâncias genéticas $\left(F_{S T}\right)$ e geográficas é negativa mas não-significante $\left(r_{S}=-0,2589 ; p=0,1833\right)$, na área ocupada pelas aldeias Pano $\left(r_{S}=0,1828 ; p=0,5143\right)$, bem como na região abrangida pelas 16 aldeias analisadas $\left(r_{S}=0,2481 ; p=0,0063\right)$, houve correlação positiva. Na análise de autocorrelação espacial observa-se correlograma que se assemelha de maneira razoável aos formatos teoricamente esperados e observados em simulações de populações evoluindo de acordo com o modelo IBD (Sokal e Wartenberg 1983; Sokal et al. 1989; Barbujani 2000), com valores de II positivos nas primeiras classes de distâncias e valores não-significantes próximos de zero nas últimas. A presença de pico negativo significante na penúltima classe de distâncias indica que este padrão de IBD foi perturbado por pressões evolutivas adicionais (Bertorelle e Barbujani 1995).

Apesar disso, conclui-se que, nesta região, a geografia é um dos fatores que estaria influenciando na moldagem da variabilidade genética, enquanto que especificamente no território que abrange as aldeias Tikúna, a organização social, representada na forma de uniões exogâmicas envolvendo membros de clãs e aldeias distintos (talvez até mesmo buscando a união entre indivíduos de aldeias mais distanciadas), e não a geografia ou afiliação lingüística, seria o provável fator influenciando a diversidade genética das aldeias de tal tribo. 


\subsection{Padrões de fluxo gênico sexo-específicos}

Diferenças nas taxas de migração entre homens e mulheres podem ser inferidas pela análise de variação do mtDNA e do cromossomo Y dentro e entre populações (Wilder et al. 2004). De fato, quanto maior for o $F_{S T}$, mais distintas serão as populações, implicando em menor fluxo gênico para homogeneizá-las. Embora o $F_{S T}$ também dependa da taxa de mutação dos marcadores utilizados, o que deveria ser incorporada à análise quando valores de $F_{S T}$ obtidos por marcadores genéticos com taxas de mutações distintas fossem comparados, esta característica tem sido ignorada sob o argumento de que sua influência seria de ordem de magnitude muitas vezes inferior do que a influência decorrente da taxa de migração (Seielstad 2000).

Visto que os haplogrupos de mtDNA e microssatélites de cromossomos Y analisados em sete aldeias do centro-oeste da Amazônia brasileira apresentam taxas mutacionais bem distintas, a análise direta de parâmetros como o $F_{S T}$, sem que sejam levadas em consideração as peculiaridades inerentes a cada marcador, poderá resultar em conclusões pouco robustas e enviesadas.

Buscando a obtenção de conclusões mais confiáveis, as inferências serão realizadas tomando-se como referencial resultados da comparação microssatélites do cromossomo Y e de RFLPs de mtDNA obtidos em 5 populações da Colômbia e em conjunto envolvendo 12 (cromossomo Y) e 20 (mtDNA) populações dispersas pela América do Sul (Mesa et al. 2000). Em ambos os casos os valores de $F_{S T}$ calculados a partir do cromossomo Y e do mtDNA foram muito semelhantes: respectivamente 0,165 e 0,180 na Colômbia e 0,299 e 0,287 no apanhado de populações da América do Sul. Neste estudo concluiu-se que não havia evidências de diferenças nas taxas migratórias masculinas e femininas ao longo da história das populações nativas sul-americanas (Mesa et al. 2000). 
Esta semelhança não foi observada na região abrangida pelo presente estudo, sendo que a heterogeneidade masculina $\left(F_{S T}=0,2612 ; p=0,0000\right)$ foi mais de duas vezes maior que a feminina $\left(F_{S T}=0,1213 ; p=0,0000\right)$. De imediato, ignorando os argumentos apresentados em parágrafos anteriores, já seria possível concluir que as mulheres da região centro-oeste da Amazônia brasileira migram mais do que os homens. Adotando-se postura cautelosa, a comparação com dados da literatura conduz a dois outros fatores que corroboram tal conclusão. Primeiro, nota-se maior homogeneidade do material genético de origem materna nas populações da Amazônia do que nas populações colombianas e que o material genético masculino apresenta estruturação equivalente à de indígenas da América do Sul, sendo bem superior à de populações colombianas. Segundo, visto que na análise de cromossomos Y em populações sul-americanas, quando se considera marcadores bi-alélicos $\left(F_{S T}=0,47\right)$ o valor de $F_{S T}$ é mais de $50 \%$ superior ao de microssatélites $\left(F_{S T}=0,299\right)$ (Mesa et al. 2000; Bortolini et al. 2002), pode-se supor que na hipótese de ocorrência de algum viés na análise de microssatélites em populações sul-americanas, tal viés conduziria à sub-estimativas das diferenças populacionais masculinas. Neste caso, a migração masculina seria ainda mais reduzida. É preciso ressaltar que ao optar pela apresentação dos resultados de aldeias, novamente foi adotada postura conservadora, visto que o agrupamento das aldeias em quatro tribos resulta em maior estruturação masculina $\left(F_{S T}=0,3482 ; p=0,0000\right)$ e maior homogeneidade feminina $\left(F_{S T}=0,0986 ; p=0,0001\right)$, sendo que o valor de $F_{S T}$ obtido com cromossomos $\mathrm{Y}$ corresponde a cerca de 3,5 vezes o valor obtido com mtDNA.

A maior homogeneidade feminina estaria se refletindo ainda na ausência de correlação significante $\left(r_{S}=0,1935 ; p=0,4006\right)$ entre as distâncias genéticas obtidas a partir do mtDNA e geográficas (Tabelas 10), enquanto que a estruturação masculina acarreta em correlação positiva $\left(r_{S}=0,6481 ; p=0,0015\right)$ entre distâncias genéticas e geográficas $\left(r_{S}=0,1935\right.$; $p=0,4006)$. Portanto, este achado parece ser bastante robusto e indica que neste contexto 
regional as mulheres realmente migrariam mais do que os homens. Esta maior taxa de migração feminina pode ser decorrente de casamentos exogâmicos ou pela eventual captura e posterior assimilação de mulheres de tribos inimigas.

Apesar de toda esta interpretação ter sido fundamentada em termos de migração masculina e feminina, diferenças nos níveis de diferenciação populacional não se relacionam apenas a este quesito. Desconsiderando a taxa de mutação e baseado no modelo de ilhas (Wright 1943), a fórmula para marcadores haplóides uni-parentais que relaciona $F_{S T}$ à migração $\left(F_{S T}=1 /(1+N m)\right)$ revela que tal parâmetro é totalmente dependente não apenas da taxa de migração $(m)$ mas também do tamanho efetivo populacional $(N)$ (Seielstad 2000). Sendo assim, fatores que levariam à redução do tamanho efetivo populacional masculino, tais como a prática comum de poliginia (associado à raridade de poliandria na maioria das culturas), maior variância no período de sucesso reprodutivo masculino e maiores taxas de mortalidade masculina, poderia resultar em maior diferenciação do cromossomo Y em relação ao mtDNA (Wilder et al. 2004). Entretanto, tem se assumido que o efeito exclusivo destes fatores não seriam suficientes para gerar diferenças de magnitude semelhante às aqui observadas (Seielstad et al. 1998; Mesa et al. 2000; Oota et al. 2001).

Partindo para escala tribal, o padrão observado na região centro-oeste da Amazônia brasileira é invertido se consideradas apenas as quatro aldeias Tikúna, sendo que o valor de $F_{S T}$ obtido com base no mtDNA $\left(F_{S T}=0,1057 ; p=0,0011\right)$ é quase cinco vezes superior ao obtido pela análise dos microssatélites $\mathrm{Y}$-específicos $\left(F_{S T}=0,0212 ; p=0,0918\right)$. Diante dos resultados da Colômbia, da América do Sul e da própria Amazônia, este resultado sugere que as mulheres estariam migrando menos do que os homens entre as aldeias desta tribo, o que, como já mencionado, é inesperado dentro de sistema de organização social patrilinear. Explicação alternativa para este achado seria a incidência de algum fator sócio-demográfico que poderia resultar em uma redução do tamanho efetivo feminino em relação ao masculino, 
como, por exemplo, uma desorganização social decorrente da explosão demográfica dos Tikúna, como já discutido anteriormente. De qualquer forma, desde o início das análises de DNA nestas amostras antigas, este foi o maior $F_{S T}$ já encontrado entre as aldeias desta tribo, o que possivelmente decorre do fato de três das aldeias aqui consideradas (Belém, Vendaval e Umariaçu) serem, dentre as oito aldeias amostradas, justamente as três aldeias Tikúna mais divergentes do ponto de vista matrilinear (Tabela 6) e estarem sendo consideradas em um contexto de apenas quatro aldeias.

\subsection{Meta-análise em escala continental}

\subsubsection{AMOVA: Aspectos lingüísticos e geográficos}

Embora a classificação lingüística proposta por Greenberg (1987) seja contestada pela grande maioria dos lingüistas, ela permanece como um dos principais dogmas contra o qual questões e hipóteses relacionadas à genética e à antropologia física de populações nativo-americanas são formuladas (Hunley e Long 2005), tratando-se de trabalho sério e convincente (CavalliSforza et al. 1994). Apesar das inconsistências, os agrupamentos lingüísticos de Greenberg (1987) constituem aproximações, ainda que imperfeitas, às estruturas genéticas de nativos norte-americanos (Hunley e Long 2005). De fato, analisando a região hipervariável do mtDNA de populações nativas da América do Norte, Hunley e Long (2005) constataram que existem diferenças significantes entre a classificação de Greenberg (1987) e a estrutura genética de tais populações, sendo que as relações genéticas entre tais populações não se ajustam a árvores lingüísticas e fortes evidências sugerem a ocorrência de fluxo gênico através das fronteiras lingüísticas. Este achado leva a crer que dificilmente alguma classificação lingüística hierárquica se ajustará perfeitamente aos dados genéticos. 
Com base nas freqüências de haplogrupos do cromossomo $\mathrm{Y}$ em populações indígenas de todo continente americano (Bolnick et al. 2004), análise de variância molecular, comparando-se estruturas hierárquicas baseadas nas classificações lingüísticas de Greenberg (1987) e Campbell (1997), revelaram que as diferenças entre os três principais grupos lingüísticos de Greenberg (1987) poderiam explicar variância genética significante $\left(\Phi_{C T}=0,319 ; p=0,027\right)$, embora inferior à variância entre os 17 grupos de Campbell $\left(\Phi_{C T}=0,448 ; p<0,001\right)$. Desta forma, de acordo com os autores, a classificação de Greenberg (1987) não deveria ser utilizada nos estudos de variabilidade genética e lingüística (Bolnick et al. 2004). Entretanto, para que houvesse este incremento de 40,4\% na magnitude de $\Phi_{C T}$, houve também incremento de $407 \%$ no número de grupos lingüísticos; os autores não se atentaram para o fato de que é estatisticamente esperado que o aumento no número de grupos resulte em aumento do $\Phi_{C T}$ (Dupanloup et al. 2002), uma vez que ocorre redução da variância devido a diferenças entre populações dentro de grupos $\left(\Phi_{C T}\right)$. Para se detectar se tal incremento da variância entre grupos é simplesmente um artefato estatístico devido ao aumento de 3 para 17 grupos, seria aconselhável verificar a partição da variância também entre os 21 subgrupos lingüísticos, que se organizam em 10 estoques culminando nas 3 famílias lingüísticas propostas por Greenberg (1987). Tal análise aplicada a estes três níveis hierárquicos da classificação lingüística de Greenberg (1987) foi aqui realizada com base nos haplogrupos de mtDNA (Tabela 12).

Considerando apenas os resultados referentes à análise das Américas, a fim de tornar mais fidedigna possível a comparação entre os dados de mtDNA e os obtidos pela análise de cromossomos Y (Bolnick et al. 2004), os presentes resultados indicam que realmente boa parte da variância é decorrente de diferenças entre as três famílias lingüísticas derivadas da classificação de Greenberg (Ameríndios, Na-Dene e Esquimós-Aleutas). No entanto, quando se desce ao nível de estoques e subgrupos lingüísticos na escala hierárquica, embora o número 
de grupos aumente de 3 para 11 e 21, respectivamente, observa-se forte redução da variância entre grupos (Tabela 12). Isto não seria esperado caso os achados anteriores (Bolnick et al. 2004) fossem decorrentes simplesmente de artefatos estatísticos. Embora existam diferenças no desenho experimental de ambos os estudos que podem estar influenciando diretamente os resultados, tais como o modo de herança dos marcadores considerados (matrilinear $\mathrm{x}$ patrilinear), a quantidade de populações analisadas (37) e a distribuição delas nos grupos lingüísticos (no caso do estudo de Bolnick et al. (2004), quando se consideram as três famílias lingüísticas propostas por Greenberg (1987) duas delas - Esquimós/Aleutas e Na-Dene apresentam apenas uma população cada e quando se consideram os grupos propostos por Campbell (1997), o mesmo ocorre com dez deles), a comparação dos estudos sugere que apesar das grandes diferenças entre as famílias determinadas por Greenberg (1987), não se pode rejeitar a hipótese de que a outra classificação (Campbell 1997) possa realmente explicar uma maior proporção da variância genética.

Quando se considera as Américas do Norte e do Sul separadamente, o aumento do número de grupos acarreta em aumento de $F_{C T}$ (Tabela 12). Esta relação pode ser facilmente explicável se for assumido que a história de divergência de línguas e populações (tribalização) se ajustam de maneira satisfatória à hierárquica lingüística. Desta forma, (a) populações de um determinado (sub)grupo lingüístico são teoricamente mais aparentadas e semelhantes entre si do que a populações de outros (sub)grupos lingüísticos que ocupam mesmo nível na escala hierárquica e (b) populações que pertencem a um determinado subgrupo lingüístico são mais aparentadas e semelhantes entre si do que populações que pertencem a um mesmo estoque lingüístico, que por sua vez são mais semelhantes entre si do que populações pertencentes a uma mesma família lingüística. Sendo assim, conforme se desce na escala hierárquica e aumenta-se o número de grupos, conseqüentemente se reduz o número de populações de cada grupo, de modo que em cada grupo serão alocadas justamente as 
populações que divergiram mais recentemente na história evolutiva (sendo conseqüentemente mais semelhantes). Isto se reflete geneticamente na redução da variância entre populações de mesmo grupo e aumento na variância entre grupos (Tabela 12).

A maior influência da afiliação lingüística na América do Norte do que na América do Sul se reflete em maior proporção da variância genética atribuível a diferenças entre subgrupos lingüísticos (ou estoques) na primeira do que na última (Tabela 12). A presença de populações das famílias Esquimó-Aleutas e Na-Dene apenas no continente norte-americano é responsável por grande parte deste achado. A diferença entre subgrupos lingüísticos não seria tão gritante entre os dois continentes se no caso da América do Norte fossem consideradas apenas as 63 populações Ameríndias que se agrupam em seis subgrupos lingüísticos $\left(F_{C T}=0,1037 ; p=0,0000\right)$.

De modo geral, nas Américas como um todo e na América do Norte, a língua (Tabela 12) exerce maior influência no padrão de variabilidade genética entre grupos de populações do que a geografia (Tabela 11), enquanto que na América do Sul este padrão se inverte. Isto fica bem evidente quando são comparados valores de $F_{C T}$ (ou da somatória $F_{C T}+F_{S C}$ ) obtidos em análises cujos números de grupos estabelecidos de acordo com critérios lingüísticos e geográficos são semelhantes (Tabelas 11 e 12). Nas Américas, a diversidade entre três famílias lingüísticas $\left(F_{C T}=0,1701\right)$ é bem maior do que entre três continentes $\left(F_{C T}=0,0674\right)$ e a diversidade entre dez estoques lingüísticos $\left(F_{C T}=0,1130\right)$ é maior do que entre 11 regiões geográficas $\left(F_{C T}=0,1021\right)$. Na América do Norte a variabilidade entre seis estoques lingüísticos $\left(F_{C T}=0,1621\right)$ é bem maior do que entre cinco regiões geográficas $\left(F_{C T}=0,1053\right)$. Apenas na América do Sul a variância entre regiões geográficas é superior $\left(F_{C T}=0,0674\right)$ à entre estoques lingüísticos $\left(F_{C T}=0,0439\right)$. 
Embora na América do Sul a variância entre regiões geográficas $\left(F_{C T}=0,0674\right)$ seja superior à variância entre estoques lingüísticos, ainda assim esta variância é menor do que na América do Norte $\left(F_{C T}=0,1053\right)$ e nas Américas $\left(F_{C T}=0,1021\right)$. Desconsiderando qualquer estrutura hierárquica, a diferença entre heterogeneidade observada na América do Norte $\left(F_{S C}=0,3151\right)$ e na América do Sul $\left(F_{S C}=0,2568\right)$ fica ainda mais evidente (Tabela 11). À princípio este resultado pode parecer totalmente contrastante ao obtido com base em dados de cromossomos Y e mtDNA (Bortolini et al. 2002), no qual foi observado na América do Sul maior nível de heterogeneidade do que na América do Norte. No entanto, a razão para que neste outro trabalho a diversidade inter-populacional relativa aos dados de mtDNA observada no continente norte-americano $\left(G_{S T}{ }^{\prime}=0,20\right)$ tenha sido tão inferior à observada no continente sul-americano $\left(G_{S T}{ }^{\prime}=0,31\right)$ certamente deriva do fato de que naquela ocasião foram consideradas apenas populações Ameríndias (excluindo-se os Na-Dene e Esquimós-Aleutas).

De fato, se o valor de $F_{S C}$ aqui apresentado relativo à América do Norte tivesse sido estimado utilizando apenas as 67 amostras populacionais que correspondem às aldeias Ameríndias $\left(F_{S C}=0,2122 ; p=0,0000\right)$ dentre as 92 inicialmente consideradas, seria $32,7 \%$ inferior ao inicialmente calculado (Tabela 11) e até mesmo menor do que o obtido na América do Sul, o que corrobora o achado de Bortolini et al. (2002). Portanto, os resultados aqui obtidos permitem concluir que quando se consideram populações nativo-americanas em geral a heterogeneidade é maior na América do Norte, enquanto que quando apenas o grupo que se expandiu e povoou toda a extensão das Américas (Ameríndios) é considerado, a heterogeneidade é maior entre populações sul-americanas. Em se tratando de nativoamericanos, a razão para maior heterogeneidade na América do Norte resulta da presença de populações de três famílias lingüísticas altamente divergentes neste continente (Tabela 12), enquanto que entre Ameríndios, possível explicação para aumento da heterogeneidade na América do Sul estaria relacionada com maior atuação da deriva genética em virtude da 
fragmentação populacional imposta pela geografia sul-americana (Cavalli-Sforza et al. 1994; Bortolini et al. 2002).

Da mesma forma que foi visto nas análises de AMOVA com agrupamentos baseados em critérios lingüísticos, o aumento do número de grupos ocasiona aumento de $F_{C T}$ quando critérios geográficos são empregados (Tabela 11). Esta relação está fundamentada no modelo de isolamento-por-distância, pelo qual populações de áreas geográficas mais restritas tendem a ser mais homogêneas devido à maior ocorrência de fluxo gênico. Desta forma, conforme se restringe a área geográfica abrangida pelos grupos, aumenta-se o número de grupos, sendo que em cada grupo serão alocadas populações de área geográfica mais restrita (e conseqüentemente mais homogênea). Isto se reflete geneticamente na redução da variância entre populações de mesmo grupo e aumento na variância entre grupos (Tabela 11). Considerando-se a América do Sul, por exemplo, o valor continental de $F_{S C}(0,2568)$ é maior do que o encontrado em qualquer uma das regiões geográficas do continente $\left(F_{S C}\right.$ varia de $0,1292$ a 0,2442$)$.

Recentemente, modelo evolutivo relacionado à evolução de populações ameríndias sul-americanas foi proposto com base em haplótipos de microssatélites do cromossomo Y (Tarazona-Santos et al. 2001a) e corroborado por seqüências de mtDNA (Fuselli et al. 2003) e marcadores clássicos (Luiselli et al. 2000). Segundo o modelo, populações que habitam a região ocidental do continente (associadas à Cordilheira dos Andes) apresentam maior tamanho efetivo populacional e fluxo gênico do que populações do leste do continente (provenientes da Bacia Amazônica, planalto central e região dos Chacos), o que levou à homogeneização das primeiras e maior divergência populacional entre as últimas. As populações ocidentais ainda exibiriam maiores níveis de variabilidade genética intra-populacional do que as encontradas no leste do continente (Tarazona-Santos et al. 2001a; Fuselli et al. 2003). Estes estudos entretanto possuem limitações quanto ao número de 
indivíduos e de populações da porção leste da América do Sul sendo o primeiro deles (Tarazona-Santos et al. 2001a) criticado por estes motivos (Rothhammer e Moraga 2001).

Tal modelo foi aqui testado com o banco de dados de haplogrupos de mtDNA disponível (Apêndice A), sendo que não se observa diferença entre as porções leste e oeste da América do $\operatorname{Sul}\left(F_{C T}=0,0033 ; p=0,1823\right)$. A variância entre as populações pertencentes a cada uma destas duas regiões geográficas é quase idêntica $\left(F_{S C}=0,2529\right.$ no Leste; $F_{S C}=0,2349$ no Oeste) (Tabela 11). Além disso, AMOVA revelou que existem diferenças entre os grupos da região Oeste (Andes e da Terra do Fogo), tida como homogênea de acordo com o modelo $\left(F_{C T}=0,1741 ; p=0,0005\right)$, bem como entre os grupos da região Leste (Amazônia e região dos Chacos) $\left(F_{C T}=0,0986 ; p=0,0001\right)$. Estes dados sugerem que o padrão evolutivo das populações indígenas sul-americanas é de complexidade maior do que a incorporada pelo modelo proposto (Tarazona-Santos et al. 2001a), o que já havia sido admitido pelos próprios autores (Tarazona-Santos et al. 2001b).

\subsubsection{Padrão geográfico da variabilidade do mtDNA nas Américas}

De modo geral, AMOVA revelou que a distribuição geográfica, bem como a afiliação lingüística, exerce grande influencia sobre a distribuição do mtDNA nas Américas. A construção de correlogramas e distogramas foi então realizada a fim de sumarizar a variabilidade genética de maneira mais objetiva e verificar se o padrão de variabilidade do mtDNA nas populações indígenas da América do Sul e do Norte se ajusta ao modelo de isolamento-por-distância (IBD).

O correlograma pode ser encarado como um sumário da superfície de variação (DinizFilho 1998). Embora a hipótese nula a ser testada, em termos estatísticos, é de distribuição espacial aleatória dos marcadores genéticos, do ponto de vista da genética de populações, tal 
distribuição aleatória seria totalmente inesperada. Uma vez que populações geograficamente mais próximas tendem a experimentar maior fluxo gênico do que populações separadas por maior distância, sendo os graus de isolamento relativo entre as localidades aproximadamente proporcionais às distâncias geográficas, o esperado é que a distribuição espacial se ajuste ao modelo IBD (Barbujani 2000).

O modelo de isolamento-por-distância prevê declínio exponencial da similaridade genética no espaço e resulta em correlogramas que partem de valores positivos altamente significantes nas primeiras classes de distâncias, declinando exponencialmente com o aumento da distância entre as localidades, até atingir valores bem próximos de zero nas últimas classes de distâncias (Sokal e Wartenberg 1983; Barbujani 1987; Sokal et al. 1989; Bertorelle e Barbujani 1995; Barbujani 2000). Por outro lado, superfícies caracterizadas por gradientes lineares puros (clinas de freqüências alélicas ou haplotípicas) resultam em correlogramas que adquirem formato de reta quase perfeita, com valores positivos altamente significantes nas primeiras classes de distâncias decrescendo de forma linear até atingir valores negativos altamente significantes nos últimos intervalos (Bertorelle e Barbujani 1995; Diniz-Filho 1998; Barbujani 2000). Em termos evolutivos, estes gradientes lineares são conseqüências de adaptação a um gradiente ambiental ou resultado de uma série de efeitos do fundador (eventos de colonização ocorrendo ao longo da onda de expansão populacional) (Bertorelle e Barbujani 1995).

Nos três correlogramas aqui obtidos os índices II partiram de valores elevados e positivos, apresentando declínio acentuado ao longo das três ou quatro primeiras classes de distâncias e declínio menos expressivo nas classes posteriores (Figura 4). Análise superficial destes correlogramas já sugere a ocorrência de um gradiente na distribuição dos haplogrupos de mtDNA, o que caracterizaria uma série de efeitos do fundador ao longo da onda de expansão populacional. Entretanto, os correlogramas da América do Norte (Figura 4b) e 
principalmente da América do Sul (Figura 4c) desviam ligeiramente deste padrão pela existência de aumento nos valores de $I I$ observável nas últimas classes de distâncias, após o qual ocorre novo declínio. Este padrão já foi observado em estudo de roedores, tendo sido interpretado como decorrente da existência de clinas ancestrais sobre as quais foram sobrepostos efeitos de fluxo gênico sucessivo, deriva genética e/ou adaptação a ambientes locais (Bertorelle e Barbujani 1995). Existe a possibilidade, portanto, dos correlogramas da América do Norte e da América do Sul estarem refletindo eventos antigos (expansão populacional caracterizada pela ocorrência de uma série de efeitos do fundador) e recentes (isolamento-por-distância, mais intensificado na América do Sul), simultaneamente. Além disso, a adaptação a climas frios e a elevadas altitudes poderia influenciar na distribuição dos haplogrupos de mtDNA (Mishmar et al. 2003), principalmente na região da Cordilheira dos Andes, o que por sua vez refletiria de alguma maneira no correlograma sul-americano (Figura 4c).

Como foi visto anteriormente, é esperado que populações intimamente relacionadas compartilhem maior variabilidade genética, apresentando menor variabilidade inter-populacional. Ainda, se as populações compartilharem origem ancestral comum, é esperado que as populações apresentem aumento dos valores de $F_{S T}$ conforme se aumenta a distância geográfica entre pares de populações (Merriwether et al. 1995). Isto foi observado de maneira evidente no correlograma das Américas (Figura 5a) e da América do Norte (Figura 5b): os valores de $F_{S T}$ nas primeiras e últimas classes de distâncias são respectivamente menores e maiores do que o esperado ao acaso $\left(F_{S T}\right.$ de referência). De acordo com a interpretação proposta (Merriwether et al. 1995), a presente análise corrobora a hipótese de que uma única onda migratória seria responsável pelo povoamento das Américas. $\mathrm{Na}$ América do Sul, além do valor de $F_{S T}$ relacionado à última classe de distâncias experimentar grande decréscimo em relação ao valor anterior, entre a segunda e a sexta 
classes de distâncias, os valores de $F_{S T}$ praticamente não se alteram, constituindo achado de difícil interpretação.

Portanto, a análise conjunta dos correlogramas e distogramas corrobora a hipótese de que uma onda migratória principal seria responsável pelo povoamento das Américas (Merriwether et al. 1995; Forster et al. 1996; Bonatto e Salzano 1997b; Silva et al. 2002). Tal onda teria se expandido e povoado a América do Norte, atravessado a América Central e alcançado a América do Sul, tendo ocorrido múltiplos efeitos do fundador ao longo deste movimento migratório. Na América do Sul, a exemplo de observações anteriores (TarazonaSantos et al. 2001a; Fuselli et al. 2003), o padrão de distribuição geográfica se mostrou mais complexo, o que pode ser decorrente do fato de mais de uma rota migratória ter sido seguida pelos primeiros colonizadores deste continente sul-americano (Schmitz 1983; Salzano e Callegari-Jacques 1988; Cavalli-Sforza et al. 1994).

Embora os distogramas e correlogramas permitam identificar a existência de correlação entre as distâncias (ou afinidades) genéticas e geográficas, tais ferramentas não proporcionam qualquer informação sobre padrões específicos de variação atuando em espaço bi-dimensional. Muitas vezes a correlação pode ser alta em uma área e insignificante em outra e esta diferença dificilmente será percebida em um gráfico que não indica onde estão as descontinuidades genéticas. Esta representação geográfica das diferenças genéticas tem sido obtida através de mapas geográficos de freqüências alélicas e componentes principais (Manni et al. 2004).

Portanto, mapas geográficos de freqüências de cada haplogrupo foram obtidos por meio da interpolação de freqüências das localidades indígenas amostradas (Figuras 6-9). Esta abordagem, também baseada em haplogrupos de mtDNA, foi utilizada na América do Norte (Malhi et al. 2002), sendo que os principais resultados dos mapas foram corroborados pela 
análise de seqüências na forma de rede de haplótipos (network) de cada haplogrupo. Os mapas aqui apresentados, no que se refere ao continente norte-americano, foram muito semelhantes aos previamente obtidos (Malhi et al. 2002), sendo que as diferenças podem ser atribuídas ao aumento do número de amostras em relação às previamente utilizadas (de 36 para 94). Com o intuito de definir melhor a distribuição dos haplogrupos indígenas na costa atlântica da América do Sul e minimizar nesta região os efeitos de autocorrelação espúria causada pelo processo de interpolação em regiões pouco amostradas (Sokal et al. 1999), mapas sul-americanos alternativos foram obtidos (Figura 10) com a incorporação de mtDNA proveniente de populações urbanas e afro-derivadas.

O haplogrupo A se encontra em maiores freqüências no extremo norte das Américas (Figura 6). A existência de um gradiente decrescente de freqüências em direção ao centro-sul da América do Norte é compatível com expansão populacional nesta direção, corroborando achado anterior (Malhi et al. 2002). Ao longo da América Central e do extremo noroeste da América do Sul (Venezuela, Colômbia e Equador) este haplogrupo encontra-se em freqüências moderadas $(40 \%-70 \%)$. A partir desta região as freqüências caem de maneira abrupta, de modo que no restante do continente as freqüências dificilmente alcançam $25 \%$. Constitui exceção justamente o sudoeste da Amazônia, região habitada pelos Pano e por indígenas bolivianos (onde as freqüências alcançam 40\%) e o norte do continente sul-americano, onde se observa um pequeno gradiente decrescente partindo da Guiana Francesa em direção à região central do Brasil. Considerando-se dados de populações de populações não-indígenas (Figura 10a), observa-se que a região nordeste do Brasil também constitui região diferenciada.

O haplogrupo B se encontra praticamente ausente na região setentrional da América do Norte (Figura 7), sendo este padrão de certa forma oposto ao do haplogrupo A (Figura 6). As freqüências mais elevadas se encontram na região oeste (Grande Bacia), da qual parte 
gradiente decrescente em direção ao leste norte-americano (Figura 7). Na América do Sul, este haplogrupo apresenta padrão de heterogeneidade espacial mais saliente do que o haplogrupo A. Ressaltam-se: (a) elevadas freqüências em quase toda a extensão da Cordilheira dos Andes, (b) baixas freqüências na Amazônia e (c) ausência completa na Terra do Fogo. Quando populações não-indígenas são incorporadas à análise (Figura 10b), observa-se que a Costa Atlântica apresenta tal haplogrupo em freqüências reduzidas, o que ressalta uma ampla região com as mais elevadas freqüências deste haplogrupo no continente sul-americano (entre 50\% e 80\%), englobando o norte do Chile, sul da Bolívia, norte do Paraguai, cerrado brasileiro (Mato Grosso, Goiás e Tocantins), Maranhão e leste do Pará. Esta região se sobrepõe de maneira quase perfeita à rota estabelecida com base em dados arqueológicos (Figura 12d). O aumento para freqüências em torno de $60 \%$ ou $70 \%$ no norte do Chile e extremo sul do Peru pode ser devido simplesmente à ação da deriva genética ou, como já proposto anteriormente (Salzano e Callegari-Jacques 1988; Cavalli-Sforza et al. 1994; Cann e Lum 1996; Lum e Cann 2000), decorrente de eventual chegada a esta região de povos polinésios, nos quais a freqüência da deleção de 9pb que caracteriza o haplogrupo B é quase fixada (entre 77\% e 100\%) (Lum et al. 1994; Lum e Cann 1998).

O mapa de freqüências interpoladas do haplogrupo $\mathrm{C}$ revela freqüências intermediárias, entre 15\% e 40\%, ao longo de grande extensão da América do Norte, exibindo redução notável em direção noroeste (Alaska) e nordeste (Groenlândia) do continente (Figura 8). O padrão observado na América do Sul (Figuras 8 e 10c) é de certa forma complementar ao encontrado no mapa do haplogrupo B (Figuras 7 e 10b): freqüências elevadas do haplogrupo B correspondem a freqüências reduzidas do haplogrupo C e vice-versa.

Em quase toda extensão da América do Norte, o haplogrupo D é encontrado em freqüências inferiores a 10\% (Figura 9), sendo observado aumento de freqüências apenas na região oeste e no Alaska. Na América do Sul, freqüências elevadas são observadas na 
Amazônia (no leste e em área ocupada pelos Tikúna na porção Oeste) e na região dos Chacos, de onde parte gradiente aumentando em direção à Terra do Fogo, onde são encontradas as maiores freqüências das Américas, ao lado das Ilhas Aleutas e do extremo oeste do Alaska (Figura 9). A inclusão de populações não-indígenas, a não ser por um leve incremento nas freqüências no extremo nordeste do Brasil (Figura 10d), não proporciona grandes alterações.

Visto que a variação geográfica nos valores de cada coordenada poderia indicar as rotas migratórias seguidas pelos ancestrais dos indígenas contemporâneos (Salzano e Callegari-Jacques 1988), as três coordenadas principais (que definem a localização de cada população no espaço tridimensional criado) de análise multidimensional aplicada a populações indígenas sul-americanas foram interpoladas separadamente em mapas geográficos (Figura 12a-c). Embora as diferentes dimensões apresentem independência estatística (Salzano e Callegari-Jacques 1988; Cavalli-Sforza et al. 1994), o que poderia permitir a identificação de fluxos migratórios distintos (Salzano e Callegari-Jacques 1988), os três mapas exibem padrões e gradientes muito semelhantes, o que torna os resultados mais robustos. A consideração simultânea dos três mapas permite identificar cinco regiões intra-continentais distintas: (a) extremo noroeste (norte da Cordilheira dos Andes), (b) Andes central, (c) oeste e centro da Amazônia, (d) extremo leste da Amazônia e leste do Brasil (Regiões Nordeste e Sudeste) e (e) sul do continente.

O primeiro componente revela gradiente crescente originando-se na América Central, passando pelo norte da Colômbia até a Venezuela (Figura 12a). Tal gradiente é compatível com rota proposta pela análise de sítios arqueológicos (Figura 12d) e polimorfismos clássicos (Schmitz 1983; Salzano e Callegari-Jacques 1988). O gradiente segue aumentando em direção ao centro da Amazônia, região esta que pode constituir um centro de convergência de migrantes vindos do norte e do oeste - sabe-se que os Tikúna e os Pano migraram para esta região a partir de regiões da Colômbia, Peru e Equador (Salzano e Jacques 1979; Salzano et 
al. 1980). Outra possibilidade é de que esta região represente uma área de dispersão populacional recente, o que seria corroborado pelo mapa do terceiro componente (Figura 12c). Gradiente ainda mais evidente parte da América Central, com os valores mais negativos do mapa, acompanha toda a Cordilheira dos Andes, até alcançar os valores mais positivos do mapa na Terra do Fogo (Figura 12a). Observa-se que na região central dos Andes não há grande alteração nos valores, o que indica se tratar de região homogeneizada por fluxo gênico intenso, o que está de acordo com dados históricos e genéticos (Tarazona-Santos et al. 2001a; Fuselli et al. 2003). Tal gradiente corrobora rota clássica ao longo da costa do Pacífico se estendendo até o extremo sul do continente. A continuidade perfeita destes dois gradientes entre a América Central (Nicarágua, Costa Rica e Panamá) e a América do Sul (se dividindo na Colômbia em direção ao leste e sul do continente) sugere que os indígenas sul-americanos contemporâneos teriam se originado de uma única onda migratória, ao contrário de proposta anterior (Keyeux et al. 2002) de que a Colômbia teria sido povoada por pelo menos duas ondas migratórias, uma mantendo relações genéticas e culturais com os povos da América Central e outra que teria se diferenciado em grupos mais heterogêneos da Amazônia ao sul do continente.

O segundo componente revela forte uniformidade de valores na região Amazônica, ao longo da Cordilheira dos Andes e na região leste do continente (Figura 12b). Os valores entre estas regiões se alteram de maneira abrupta, sem a formação de gradiente entre elas. Único gradiente visível parte de valores positivos, no norte do Chile e na região dos Chacos, até valores negativos na Terra do Fogo. O mapa referente ao terceiro componente (Figura 12c) é muito semelhante ao do primeiro (Figura 12a). A principal diferença está na separação da porção oeste da Amazônia da porção central da mesma. Observa-se a presença de gradiente decrescente partindo da América Central em direção ao centro da porção oeste da Amazônia. 
Esta região por sua vez apresenta gradiente crescente em direção ao norte e ao sul, o que seria compatível com expansão populacional a partir desta região.

Por fim, análise detalhada dos mapas relativos aos três componentes (principalmente os dois primeiros) permite identificar uma faixa de valores bastante homogêneos que já havia sido observada pela análise do haplogrupo B e C (Figuras 10b,c) que se estende do norte do Chile ao Pará. Quer tenha ocorrido ou não a chegada de polinésios a esta região da costa do Oceano Pacífico (o que teria elevado as freqüências do haplogrupo B), esta faixa é compatível com rota caracterizada por fluxo gênico contínuo de curta e longa distância, o que evitaria a formação de gradiente e manteria a homogeneidade. Desta forma, corrobora rota proposta com base em registros arqueológicos (Figura 12d) (Schmitz 1983; Salzano e CallegariJacques 1988). É muito mais provável que a presença de gradientes na forma de círculos concêntricos partindo do Maranhão seja artefato da interpolação devido à escassez de localidades amostradas nas Regiões Nordeste, Sudeste e Sul, do que indicativo de expansão populacional nesta região acompanhando a costa Atlântica em direção ao Sul do Brasil, como previamente sugerido (Schmitz 1983; Salzano e Callegari-Jacques 1988). A amostragem de maior quantidade de populações na região leste do continente seria necessária para tornar estes dois achados mais robustas.

De modo geral, os mapas aqui apresentados trazem gradientes que corroboram as duas principais rotas migratórias postuladas: ao norte, acompanhando a costa Atlântica em direção ao leste da América do Sul, e em direção ao sul, acompanhando a costa do Oceano Pacífico. Duas rotas migratórias secundárias, partindo da porção final da América Central em direção ao centro da Amazônia, e partindo do norte do Chile e sul do Peru em direção ao leste do Pará e Maranhão, também são possíveis. Embora estes resultados sejam fundamentados em marcador de herança matrilinear, que indicaria os movimentos seguidos pelas mulheres, as principais rotas migratórias foram necessariamente percorridas por diversos membros de 
ambos os sexos, ao longo de centenas ou milhares de anos. Mesmo que haja diferenças nos tamanhos efetivos populacionais de homens e mulheres, vestígios destes movimentos em comum estariam presentes nas populações contemporâneas masculina e feminina. Portanto, a análise de outros conjuntos de marcadores moleculares, até mesmo de padrões de herança patrilineares, seria pertinente para se testar as rotas secundárias aqui sugeridas, bem como as rotas clássicas anteriormente propostas e aqui corroboradas. 


\section{Conclusões}

As hipóteses formuladas foram testadas e todos os objetivos propostos foram cumpridos. Dentre as conclusões obtidas, seguem abaixo as relevantes.

O haplogrupo $\mathrm{X}$, encontrado entre populações indígenas norte-americanas, não foi observado na presente amostra. Nenhum haplogrupo de origem européia e apenas um de origem africana (haplogrupo L) foi encontrado. A estimativa de mistura inter-étnica obtida $(0,32 \%)$ é concordante com estimativas anteriores baseadas em marcadores clássicos, enquanto que a ocorrência de mistura masculina (pelo menos 1,31\%) é ligeiramente maior. A mistura feminina é praticamente desprezível sendo o pouco fluxo gênico inter-étnico existente mediado principalmente por homens.

Existe heterogeneidade intra-tribal nos Tikúna, sendo observados dois grupos altamente homogêneos (um deles formado por Belém e Vendaval e o outro formado pelas seis outras aldeias) que diferem consideravelmente entre si. Aparentemente a diferenciação entre Belém e Vendaval estaria ocorrendo de maneira muito mais intensa entre as linhagens femininas e, embora a tendência à exogamia seja reduzida nestas duas aldeias, o fluxo gênico mediado por homens estaria ocorrendo em intensidade suficiente para homogeneizar o restante do material genético. Este achado contraria a hipótese formulada quanto à homogeneidade dos Tikúna.

As análises de distâncias genéticas entre pares de aldeias ou tribos indicam que os Tikúna são relativamente mais divergentes do que as demais populações (a tribo Marúbo também se apresentou divergente). Estes resultados sugerem relativo isolamento tribal dos Tikúna, embora não permitam comprovar e quantificar a intensidade de tal isolamento. 
A homogeneidade lingüística e cultural dos Pano não se reflete na estrutura genética deste grupo, visto que os níveis de heterogeneidade entre populações Pano são equivalentes ou até mesmo superiores aos observados entre populações de afiliação lingüística distintas.

A afiliação lingüística não é fator responsável pela distribuição da variabilidade dos haplogrupos de mtDNA na região centro-oeste da Amazônia. A geografia é um destes fatores, enquanto que, especificamente entre os Tikúna, a organização social, representada na forma de uniões exogâmicas envolvendo membros de clãs e aldeias distintos, seria um fator influenciando a diversidade genética das aldeias de tal tribo.

As mulheres indígenas da região centro-oeste da Amazônia se apresentaram mais heterogêneas do que os homens. Deste achado deriva a conclusão de que as mulheres desta região migram mais do que os homens. Este padrão se inverte quando apenas aldeias Tikúna são consideradas.

Análises em escalas continentais confirmaram que os haplogrupos de mtDNA constituem ferramenta informativa, proporcionando uma visão geral da história populacional feminina recente dos indígenas sul-americanos. Por meio de análises continentais foi visto que tanto a afiliação lingüística quanto a geografia exercem forte influência no padrão de variabilidade genética sendo a primeira mais influente em toda extensão continental e na América do Norte, enquanto que na América do Sul a geografia exerce efeito maior do que a afiliação lingüística.

Quando apenas populações ameríndias são consideradas, a heterogeneidade é maior entre populações sul-americanas, o que estaria relacionado com maior atuação da deriva genética em virtude da fragmentação populacional imposta pela geografia sul-americana, corroborando achados anteriores (Bortolini et al. 2002). Por outro lado, o padrão evolutivo 
das populações indígenas sul-americanas aparenta ser de complexidade maior do que a incorporada por modelo proposto recentemente (Tarazona-Santos et al. 2001a).

Os dados corroboram a hipótese de que uma onda migratória principal seria responsável pelo povoamento das Américas. Ao longo deste movimento migratório, múltiplos efeitos do fundador teriam ocorrido até alcançar a América do Sul. Ao entrar na América do Sul, tal onda teria assumido pelo menos duas rotas principais: ao norte (acompanhando a costa Atlântica em direção ao leste do continente), em direção ao sul (acompanhando a costa do Oceano Pacífico) e, possivelmente, em direção ao centro da Amazônia. Existe também a possibilidade de uma quarta rota migratória partindo da região central dos Andes (norte do Chile e sul do Peru) em direção ao leste do Pará e Maranhão. 


\section{Referências Bibliográficas}

Abé-Sandes K (2002) Diversidade genética de afro-brasileiros: DNA mitocondrial e Cromossomo Y. Tese de Doutorado apresentada à Faculdade de Medicina de Ribeirão Preto, da Universidade de São Paulo

Alves-Silva J, da Silva Santos M, Guimaraes PE, Ferreira AC, Bandelt HJ, Pena SD, Prado VF (2000) The ancestry of Brazilian mtDNA lineages. Am J Hum Genet 67:444-61

Ayres M, Ayres Jr M, Ayres DL, Santos AAS (2000) BioEstat 2.0: aplicações estatísticas nas áreas das ciências biológicas e médicas

Bailliet G, Castilla EE, Adams JP, Orioli IM, Martinez-Marignac VL, Richard SM, Bianchi NO (2001) Correlation between molecular and conventional genealogies in Aicuna: a rural population from Northwestern Argentina. Hum Hered 51:150-9

Bailliet G, Rothhammer F, Carnese FR, Bravi CM, Bianchi NO (1994) Founder mitochondrial haplotypes in Amerindian populations. Am J Hum Genet 55:27-33

Barbujani G (1987) Autocorrelation of gene frequencies under isolation by distance. Genetics 117:777-82

Barbujani G (2000) Geographic patterns: how to identify them and why. Hum Biol 72:133-53

Batista dos Santos SE, Rodrigues JD, Ribeiro-dos-Santos AK, Zago MA (1999) Differential contribution of indigenous men and women to the formation of an urban population in the Amazon region as revealed by mtDNA and Y-DNA. Am J Phys Anthropol 109:175-80

Batista O, Kolman CJ, Bermingham E (1995) Mitochondrial DNA diversity in the Kuna Amerinds of Panama. Hum Mol Genet 4:921-9

Bert F, Corella A, Gene M, Perez-Perez A, Turbon D (2001) Major mitochondrial DNA haplotype heterogeneity in highland and lowland Amerindian populations from Bolivia. Hum Biol 73:1-16

Bertorelle G, Barbujani G (1995) Analysis of DNA diversity by spatial autocorrelation. Genetics 140:811-9

Bianchi NO, Bailliet G, Bravi CM (1995) Peopling of the Americas as inferred through the analysis of mitochondrial DNA. Braz J Genet 18:661-8

Bianchi NO, Bailliet G, Bravi CM, Carnese RF, Rothhammer F, Martinez-Marignac VL, Pena SD (1997) Origin of Amerindian Y-chromosomes as inferred by the analysis of six polymorphic markers. Am J Phys Anthropol 102:79-89

Bianchi NO, Catanesi CI, Bailliet G, Martinez-Marignac VL, Bravi CM, Vidal-Rioja LB, Herrera RJ, Lopez-Camelo JS (1998) Characterization of ancestral and derived Ychromosome haplotypes of New World native populations. Am J Hum Genet 63:1862-71 
Bogan L (1998) Calculator for distances between geographical locations. Disponível em: $<$ http://www.go.ednet.ns.ca/ larry/bsc/jslatlng.html>. Acesso em: 11 abr. 2005

Boles TC, Snow CC, Stover E (1995) Forensic DNA testing on skeletal remains from mass graves: a pilot project in Guatemala. J Forensic Sci 40:349-55

Bolnick DA, Shook BA, Campbell L, Goddard I (2004) Problematic use of Greenberg's linguistic classification of the Americas in studies of Native American genetic variation. Am J Hum Genet 75:519-22

Bolnick DA, Smith DG (2003) Unexpected patterns of mitochondrial DNA variation among Native Americans from the southeastern United States. Am J Phys Anthropol 122:336-54

Bonatto SL, Salzano FM (1997a) Diversity and age of the four major mtDNA haplogroups, and their implications for the peopling of the New World. Am J Hum Genet 61:1413-23

Bonatto SL, Salzano FM (1997b) A single and early migration for the peopling of the Americas supported by mitochondrial DNA sequence data. Proc Natl Acad Sci U S A 94:1866-71

Bortolini MC, Da Silva WAJW, De Guerra DC, Remonatto G, Mirandola R, Hutz MH, Weimer TA, Silva MC, Zago MA, Salzano FM (1999) African-derived South American populations: a history of symmetrical and asymmetrical matings according to sex revealed by bi- and uni- parental genetic markers. Am J Hum Biol 11:551-63

Bortolini MC, Salzano FM, Bau CH, Layrisse Z, Petzl-Erler ML, Tsuneto LT, Hill K, Hurtado AM, Castro-De-Guerra D, Bedoya G, Ruiz-Linares A (2002) Y-chromosome biallelic polymorphisms and Native American population structure. Ann Hum Genet $66: 255-9$

Bortolini MC, Salzano FM, Thomas MG, Stuart S, Nasanen SP, Bau CH, Hutz MH, Layrisse Z, Petzl-Erler ML, Tsuneto LT, Hill K, Hurtado AM, Castro-de-Guerra D, Torres MM, Groot H, Michalski R, Nymadawa P, Bedoya G, Bradman N, Labuda D, Ruiz-Linares A (2003) Y-chromosome evidence for differing ancient demographic histories in the Americas. Am J Hum Genet 73:524-39

Bravi CM, Bailliet G, Martinez-Marignac VL, Bianchi NO (2000) Origin of YAP+ lineages of the human Y-chromosome. Am J Phys Anthropol 112:149-58

Bravi CM, Sans M, Bailliet G, Martinez-Marignac VL, Portas M, Barreto I, Bonilla C, Bianchi NO (1997) Characterization of mitochondrial DNA and Y-chromosome haplotypes in a Uruguayan population of African ancestry. Hum Biol 69:641-52

Brown MD, Hosseini SH, Torroni A, Bandelt HJ, Allen JC, Schurr TG, Scozzari R, Cruciani F, Wallace DC (1998) mtDNA haplogroup X: an ancient link between Europe/Western Asia and North America? Am J Hum Genet 63:1852-61

Budowle B, Allard MW, Fisher CL, Isenberg AR, Monson KL, Stewart JE, Wilson MR, Miller KW (2002) HVI and HVII mitochondrial DNA data in Apaches and Navajos. Int J Legal Med 116:212-5 
Burton ML, Moore CC, Whiting JWM, Romney AK (1996) Regions based on social structure. Curr Anthropol 37:87-123

Callegari-Jacques SM (2003) Bioestatística: princípios e aplicações. Artmed, Porto Alegre

Callegari-Jacques SM, Salzano FM (1999) Brazilian Indian/non-Indian interactions and their effects. Ciência e Cultura: Journal of the Brazilian Association for the Advancement of Science 51:166-174

Campbell L (1997) American Indian languages: the historical linguistics of Native America. Oxford University Press, New York

Cann RL, Lum JK (1996) Mitochondrial myopia: reply to Bonatto et al. Am J Hum Genet 59:256-8

Carlyle SW, Parr RL, Hayes MG, O'Rourke DH (2000) Context of maternal lineages in the Greater Southwest. Am J Phys Anthropol 113:85-101

Carvajal-Carmona LG, Ophoff R, Service S, Hartiala J, Molina J, Leon P, Ospina J, Bedoya G, Freimer N, Ruiz-Linares A (2003) Genetic demography of Antioquia (Colombia) and the Central Valley of Costa Rica. Hum Genet 112:534-41

Carvajal-Carmona LG, Soto ID, Pineda N, Ortiz-Barrientos D, Duque C, Ospina-Duque J, McCarthy M, Montoya P, Alvarez VM, Bedoya G, Ruiz-Linares A (2000) Strong Amerind/white sex bias and a possible Sephardic contribution among the founders of a population in northwest Colombia. Am J Hum Genet 67:1287-95

Carvalho BM, Elleres HPC, Ribeiro-dos-Santos AKC (2002) Polimorfismo do mtDNA em duas populações afro-brasileiras da Amazônia: Pontal e Marajó. Painel apresentado no 48 Congresso Brasileiro de Genética. Águas de Lindóia, 17-20 de Setembro de 2002

Carvalho BM, Feio-dos-Santos AC, Fernandes DRS, Santos SEB, Ribeiro-dos-Santos AKC (2001) Polimorfismo do mtDNA em duas populações afro-brasileiras da Amazônia: Pacoval e Trombetas. Painel apresentado no 47 Congresso Nacional de Genética. Águas de Lindóia, 2-5 de Outubro de 2001

Carvalho BM, Freitas NSC, Leal-Mesquita ER, Ribeiro-dos-Santos AKC (2004) Polimorfismo do mtDNA em duas populações da Amazônia: Pitimandeua - PA e Santa Flor - MA. Painel apresentado no 50 Congresso Brasileiro de Genética. Florianópolis, 710 de Setembro de 2004

Carvalho BM, Ribeiro-dos-Santos AKC (2003) A importância da contribuição ameríndia em Tamauari - MA (uma população afro-brasileira da Amazônia). Painel apresentado no 49 Congresso Brasileiro de Genética. Águas de Lindóia, 16-19 de Setembro de 2003

Carvalho-Silva DR, Santos FR, Rocha J, Pena SD (2001) The phylogeography of Brazilian Ychromosome lineages. Am J Hum Genet 68:281-6

Castro-de-Guerra D, H. IM, Figuera C, Gonzáles N (2003) Mitochondrial DNA reveal differences in the population structure in semi-isolated Venezuelan populations. Painel apresentado no 49 Congresso Brasileiro de Genética. Águas de Lindóia, 16-19 de Setembro de 2003 
Cavalli-Sforza LL, Menozzi P, Piazza A (1994) The history and geography of human genes. Princeton University Press, Princeton

Crawford MH (1998) The origins of Native Americans: evidence from anthropological genetics. Cambridge University Press, Cambridge

Cruxent JM (1968) Theses for meditation on the origin and distribution of man in South America. In: Biomedical chalenges presented by the American Indian Pan American Health Organization Scientific Publication. Vol 165, Washington, D. C., pp 11-16

Degen B, Petit R, Kremer A (2001) SGS--Spatial Genetic Software: a computer program for analysis of spatial genetic and phenotypic structures of individuals and populations. $\mathrm{J}$ Hered 92:447-9

Demarchi DA, Panzetta-Dutari GM, Motran CC, Lopez de Basualdo MA, Marcellino AJ (2001) Mitochondrial DNA haplogroups in Amerindian populations from the Gran Chaco. Am J Phys Anthropol 115:199-203

Derbeneva OA, Sukernik RI, Volodko NV, Hosseini SH, Lott MT, Wallace DC (2002) Analysis of mitochondrial DNA diversity in the aleuts of the commander islands and its implications for the genetic history of beringia. Am J Hum Genet 71:415-21

Dillehay TD (2000) The settlement of the Americas: a new prehistory. Basic Books, New York

Diniz-Filho JA (1998) Análise de autocorrelação espacial: inferências microevolutivas e aplicações em genética de populações. In. Série Monografias. Vol 6. Sociedade Brasileira de Genética, Ribeirão Preto, pp 83-145

Dipierri JE, Alfaro E, Martinez-Marignac VL, Bailliet G, Bravi CM, Cejas S, Bianchi NO (1998) Paternal directional mating in two Amerindian subpopulations located at different altitudes in northwestern Argentina. Hum Biol 70:1001-10

Dornelles CL, Bonatto SL, De Freitas LB, Salzano FM (2004) Is haplogroup X present in extant South American Indians? Am J Phys Anthropol - In press

Dupanloup I, Schneider S, Excoffier L (2002) A simulated annealing approach to define the genetic structure of populations. Mol Ecol 11:2571-81

Dupanloup I, Schneider S, Langaney A, Excoffier L (2000) Inferring the impact of linguistic boundaries on population differentiation: application to the Afro-Asiatic-Indo-European case. Eur J Hum Genet 8:750-6

Easton RD, Merriwether DA, Crews DE, Ferrell RE (1996) mtDNA variation in the Yanomami: evidence for additional New World founding lineages. Am J Hum Genet 59:213-25

Elson JL, Turnbull DM, Howell N (2004) Comparative genomics and the evolution of human mitochondrial DNA: assessing the effects of selection. Am J Hum Genet 74:229-38

Erikson P (1998) Uma singular pluralidade: a etno-história pano. In: Cunha MC (ed) História dos índios no Brasil. Companhia das Letras, São Paulo, pp 239-252 
Eshleman JA, Malhi RS, Johnson JR, Kaestle FA, Lorenz J, Smith DG (2004) Mitochondrial DNA and prehistoric settlements: native migrations on the western edge of North America. Hum Biol 76:55-75

Excoffier L, Smouse PE, Quattro JM (1992) Analysis of molecular variance inferred from metric distances among DNA haplotypes: application to human mitochondrial DNA restriction data. Genetics 131:479-91

Eyre-Walker A, Awadalla P (2001) Does human mtDNA recombine? J Mol Evol 53:430-5

Fagundes NJ, Bonatto SL, Callegari-Jacques SM, Salzano FM (2002) Genetic, geographic, and linguistic variation among South American Indians: possible sex influence. Am J Phys Anthropol 117:68-78

Fay JC, Wu CI (1999) A human population bottleneck can account for the discordance between patterns of mitochondrial versus nuclear DNA variation. Mol Biol Evol 16:10035

Feio-dos-Santos AC, Carvalho BM, Santos SEB, Ribeiro-dos-Santos AKC (2001) Contribuição genética através do mtDNA de uma população urbana da Amazônia: Santarém - PA. Painel apresentado no 47 Congresso Nacional de Genética. Águas de Lindóia, 2-5 de Outubro de 2001

Felsenstein J (1989) PHYLIP-phylogeny inference package (version 3.2). Cladistics 5:164-6

Fiedel SJ (2000) The peopling of the New World: present evidence, new theories, and future directions. J Archaeol Res 8:39-103

Fix AG (2002) Colonization models and initial genetic diversity in the Americas. Hum Biol $74: 1-10$

Fladmark KR (1979) Routes - alternate migration corridors for early man in North-America. Am Antiq 44:55-69

Forster P (2004) Ice Ages and the mitochondrial DNA chronology of human dispersals: a review. Philos Trans R Soc Lond B Biol Sci 359:255-64

Forster P, Harding R, Torroni A, Bandelt HJ (1996) Origin and evolution of Native American mtDNA variation: a reappraisal. Am J Hum Genet 59:935-45

Forster P, Rohl A, Lunnemann P, Brinkmann C, Zerjal T, Tyler-Smith C, Brinkmann B (2000) A short tandem repeat-based phylogeny for the human Y chromosome. Am J Hum Genet 67:182-96

Fuselli S, Tarazona-Santos E, Dupanloup I, Soto A, Luiselli D, Pettener D (2003) Mitochondrial DNA diversity in South America and the genetic history of Andean highlanders. Mol Biol Evol 20:1682-91

García F, Moraga M, Vera S, Henríquez H, Llop H, Ocampo C, Aspillaga E, Rothhammer F (2004) Origin and microdifferentiation of Chiloé Archipelago population. Rev Chil Hist Nat 77:539-46 
Gershowitz H, Neel JV (1978) The immunoglobulin allotypes (Gm and Km) of twelve Indian tribes of Central and South America. Am J Phys Anthropol 49:289-301

Ginther C, Corach D, Penacino A, Rey JA, Carnese FR, Hutz MH, Anderson A, Just J, Salzano FM, King MC (1993) Genetic variation among the Mapuche Indians from the Patagonian region of Argentina: mitochondrial DNA sequence variation and allele frequencies of several nuclear genes. In: Pena SDJ, Chakraborty R, Epplen JT, Jeffreys AJ (eds) DNA fingerprinting: state of the science. Birkhauser Verlag, Basel, pp 211-219

Goicoechea AS, Carnese FR, Caratini AL, Avena S, Salaberry M, Salzano FM (2000) Demography, genetic diversity, and population relationships among Argentinean Mapuche Indians. Gen Mol Biol 23:513-8

Goicoechea AS, Carnese FR, Dejean C, Avena SA, Weimer TA, Franco MH, CallegariJacques SM, Estalote AC, Simoes ML, Palatnik M, Salzano FM (2001) Genetic relationships between Amerindian populations of Argentina. Am J Phys Anthropol 115:133-43

Gonzalez-Oliver A, Marquez-Morfin L, Jimenez JC, Torre-Blanco A (2001) Founding Amerindian mitochondrial DNA lineages in ancient Maya from Xcaret, Quintana Roo. Am J Phys Anthropol 116:230-5

Green LD, Derr JN, Knight A (2000) mtDNA affinities of the peoples of North-Central Mexico. Am J Hum Genet 66:989-98

Greenberg JH (1987) Language in the Americas. Stanford University Press, Stanford

Greenberg JH, Turner CG, Zegura SL (1986) The settlement of the America - a comparison of the linguistic, dental, and genetic-evidence. Curr Anthropol 27:477-97

Gruhn R (1988) Linguistic evidence in support of the coastal route of earliest entry into the New World. Man 23:77-100

Hauswirth WW, Dickel CD, Rowold DJ, Hauswirth MA (1994) Inter- and intrapopulation studies of ancient humans. Experientia 50:585-91

Henríquez HB, Moraga MV, Llop ER, Rothhammer FE (2004) Molecular and genetic characterization of Changos descendants living in Paposo Cove. Rev Med Chile 132:66372

Higuchi R (1989) Simple and rapid preparation of samples for PCR. In: Erlich HA (ed) PCR technology: principles an applications for DNA amplification. Stockton Press, New York pp 31-8

Horai S, Kondo R, Nakagawa-Hattori Y, Hayashi S, Sonoda S, Tajima K (1993) Peopling of the Americas, founded by four major lineages of mitochondrial DNA. Mol Biol Evol $10: 23-47$

Hunley K, Long JC (2005) Gene flow across linguistic boundaries in Native North American populations. Proc Natl Acad Sci U S A 102:1312-7 
Huoponen K, Torroni A, Wickman PR, Sellitto D, Gurley DS, Scozzari R, Wallace DC (1997) Mitochondrial DNA and Y chromosome-specific polymorphisms in the Seminole Tribe of Florida. Eur J Hum Genet 5:25-34

Instituto Socioambiental (2003a) Enciclopédia dos povos indígenas. Disponível em: $<$ http://www.socioambiental.org/pib/portugues/quonqua/cadapovo.shtm $>$. Acesso em: 11 abr. 2005

Instituto Socioambiental (2003b) Povos indígenas no Brasil. Disponível em: $<$ http://www.socioambiental.org/pib/portugues/quonqua/quadro.asp $>$. Acesso em: $11 \mathrm{abr}$. 2005

Jorde LB, Rogers AR, Bamshad M, Watkins WS, Krakowiak P, Sung S, Kere J, Harpending HC (1997) Microsatellite diversity and the demographic history of modern humans. Proc Natl Acad Sci U S A 94:3100-3

Jorde LB, Watkins WS, Bamshad MJ, Dixon ME, Ricker CE, Seielstad MT, Batzer MA (2000) The distribution of human genetic diversity: a comparison of mitochondrial, autosomal, and Y-chromosome data. Am J Hum Genet 66:979-88

Kaestle FA, Smith DG (2001) Ancient mitochondrial DNA evidence for prehistoric population movement: the Numic expansion. Am J Phys Anthropol 115:1-12

Karafet T, Zegura SL, Vuturo-Brady J, Posukh O, Osipova L, Wiebe V, Romero F, Long JC, Harihara S, Jin F, Dashnyam B, Gerelsaikhan T, Omoto K, Hammer MF (1997) Y chromosome markers and Trans-Bering Strait dispersals. Am J Phys Anthropol 102:30114

Karafet TM, Zegura SL, Posukh O, Osipova L, Bergen A, Long J, Goldman D, Klitz W, Harihara S, de Knijff P, Wiebe V, Griffiths RC, Templeton AR, Hammer MF (1999) Ancestral Asian source(s) of new world Y-chromosome founder haplotypes. Am J Hum Genet 64:817-31

Keyeux G, Rodas C, Gelvez N, Carter D (2002) Possible migration routes into South America deduced from mitochondrial DNA studies in Colombian Amerindian populations. Hum Biol 74:211-33

Kittles RA, Bergen AW, Urbanek M, Virkkunen M, Linnoila M, Goldman D, Long JC (1999) Autosomal, mitochondrial, and Y chromosome DNA variation in Finland: evidence for a male-specific bottleneck. Am J Phys Anthropol 108:381-99

Kolman CJ, Bermingham E (1997) Mitochondrial and nuclear DNA diversity in the Choco and Chibcha Amerinds of Panama. Genetics 147:1289-302

Kolman CJ, Bermingham E, Cooke R, Ward RH, Arias TD, Guionneau-Sinclair F (1995) Reduced mtDNA diversity in the Ngobe Amerinds of Panama. Genetics 140:275-83

Kraytsberg Y, Schwartz M, Brown TA, Ebralidse K, Kunz WS, Clayton DA, Vissing J, Khrapko K (2004) Recombination of human mitochondrial DNA. Science 304:981

Kruskal JB (1964) Nonmetric multidimensional-scaling - a numerical-method. Psychometrika 29:115-29 
Kruskal JB, Wish M (1978) Multidimensional scaling. Sage Publications, Beverly Hills

Lalueza-Fox C (1996) Mitochondrial DNA haplogoups in four tribes from Tierra del FuegoPatagonia: inferences about the peopling of Americas. Hum Biol 68:855-71

Lalueza-Fox C, Calderon FL, Calafell F, Morera B, Bertranpetit J (2001) MtDNA from extinct Tainos and the peopling of the Caribbean. Ann Hum Genet 65:137-51

Lalueza-Fox C, Gilbert MT, Martinez-Fuentes AJ, Calafell F, Bertranpetit J (2003) Mitochondrial DNA from pre-Columbian Ciboneys from $\mathrm{Cuba}$ and the prehistoric colonization of the Caribbean. Am J Phys Anthropol 121:97-108

Lalueza-Fox C, Perez-Perez A, Prats E, Cornudella L, Turbon D (1997) Lack of founding Amerindian mitochondrial DNA lineages in extinct aborigines from Tierra del FuegoPatagonia. Hum Mol Genet 6:41-6

Lell JT, Brown MD, Schurr TG, Sukernik RI, Starikovskaya YB, Torroni A, Moore LG, Troup GM, Wallace DC (1997) Y chromosome polymorphisms in native American and Siberian populations: identification of native American Y chromosome haplotypes. Hum Genet 100:536-43

Lell JT, Sukernik RI, Starikovskaya YB, Su B, Jin L, Schurr TG, Underhill PA, Wallace DC (2002) The dual origin and Siberian affinities of Native American Y chromosomes. Am J Hum Genet 70:192-206

Lewis CM, Jr., Tito RY, Lizarraga B, Stone AC (2004) Land, language, and loci: mtDNA in Native Americans and the genetic history of Peru. Am J Phys Anthropol - In press

Long JC, Kittles RA (2003) Human genetic diversity and the nonexistence of biological races. Hum Biol 75:449-71

Lorenz JG, Smith DG (1994) Distribution of the 9-bp mitochondrial DNA region V deletion among North American Indians. Hum Biol 66:777-88

Lorenz JG, Smith DG (1996) Distribution of four founding mtDNA haplogroups among Native North Americans. Am J Phys Anthropol 101:307-23

Luiselli D, Simoni L, Tarazona-Santos E, Pastor S, Pettener D (2000) Genetic structure of Quechua-speakers of the Central Andes and geographic patterns of gene frequencies in South Amerindian populations. Am J Phys Anthropol 113:5-17

Luizon MR (2003) Polimorfismos de DNA população-específicos em indígenas da Amazônia brasileira. Dissertação de Mestrado apresentada à Faculdade de Medicina de Ribeirão Preto, da Universidade de São Paulo

Lum JK, Cann RL (1998) mtDNA and language support a common origin of Micronesians and Polynesians in Island Southeast Asia. Am J Phys Anthropol 105:109-19

Lum JK, Cann RL (2000) mtDNA lineage analyses: origins and migrations of Micronesians and Polynesians. Am J Phys Anthropol 113:151-68 
Lum JK, Rickards O, Ching C, Cann RL (1994) Polynesian mitochondrial DNAs reveal three deep maternal lineage clusters. Hum Biol 66:567-90

Maciel-Braga AC, Carvalho BM, Freitas NSC, Ribeiro-dos-Santos AKC (2004) Polimorfismos do DNA mitocondrial em uma população japonesa residente na Amazônia: Tomé-açú, PA. Painel apresentado no 50 Congresso Brasileiro de Genética. Florianópolis, 7-10 de Setembro de 2004

Malaspina P, Cruciani F, Santolamazza P, Torroni A, Pangrazio A, Akar N, Bakalli V, Brdicka R, Jaruzelska J, Kozlov A, Malyarchuk B, Mehdi SQ, Michalodimitrakis E, Varesi L, Memmi MM, Vona G, Villems R, Parik J, Romano V, Stefan M, Stenico M, Terrenato L, Novelletto A, Scozzari R (2000) Patterns of male-specific inter-population divergence in Europe, West Asia and North Africa. Ann Hum Genet 64:395-412

Malhi RS, Breece KE, Shook BA, Kaestle FA, Chatters JC, Hackenberger S, Smith DG (2004) Patterns of mtDNA diversity in northwestern North America. Hum Biol 76:33-54

Malhi RS, Eshleman JA, Greenberg JA, Weiss DA, Schultz Shook BA, Kaestle FA, Lorenz JG, Kemp BM, Johnson JR, Smith DG (2002) The structure of diversity within New World mitochondrial DNA haplogroups: implications for the prehistory of North America. Am J Hum Genet 70:905-19

Malhi RS, Mortensen HM, Eshleman JA, Kemp BM, Lorenz JG, Kaestle FA, Johnson JR, Gorodezky C, Smith DG (2003) Native American mtDNA prehistory in the American Southwest. Am J Phys Anthropol 120:108-24

Malhi RS, Schultz BA, Smith DG (2001) Distribution of mitochondrial DNA lineages among Native American tribes of Northeastern North America. Hum Biol 73:17-55

Malhi RS, Smith DG (2002) Haplogroup X confirmed in prehistoric North America. Am J Phys Anthropol 119:84-6

Manly BFJ (1997) Randomization, bootstrap and Monte Carlo methods in biology. Chapman and Hall, London

Manni F, Guerard E, Heyer E (2004) Geographic patterns of (genetic, morphologic, linguistic) variation: how barriers can be detected by using Monmonier's algorithm. Hum Biol 76:173-90

Marrero AR, Carvalho BA, Leite FPN, Cruz IBM, Silva-Júnior WA, Salzano FM, Bortolini MC (2004) Heterogeneidade da ancestralidade do genoma mitocondrial de indivíduos identificados como brancos no Estado Rio Grande do Sul, Brasil. Painel apresentado no 50 Congresso Brasileiro de Genética. Florianópolis, 7-10 de Setembro de 2004

Martin PS (1973) Discovery of America. Science 179:969-74

Martinez-Cruzado JC, Toro-Labrador G, Ho-Fung V, Estevez-Montero MA, LobainaManzanet A, Padovani-Claudio DA, Sanchez-Cruz H, Ortiz-Bermudez P, Sanchez-Crespo A (2001) Mitochondrial DNA analysis reveals substantial Native American ancestry in Puerto Rico. Hum Biol 73:491-511 
Mendes-Junior CT (2001) Freqüências alélicas de polimorfismos de DNA do tipo STR em indígenas da Amazônia brasileira. Dissertação de Mestrado apresentada à Faculdade de Medicina de Ribeirão Preto, da Universidade de São Paulo

Menozzi P, Piazza A, Cavallisforza L (1978) Synthetic maps of human gene-frequencies in Europeans. Science 201:786-92

Merriwether DA, Ferrell RE (1996) The four founding lineage hypothesis for the New World: a critical reevaluation. Mol Phylogenet Evol 5:241-6

Merriwether DA, Hall WW, Vahlne A, Ferrell RE (1996) mtDNA variation indicates Mongolia may have been the source for the founding population for the New World. Am J Hum Genet 59:204-12

Merriwether DA, Huston S, Iyengar S, Hamman R, Norris JM, Shetterly SM, Kamboh MI, Ferrell RE (1997a) Mitochondrial versus nuclear admixture estimates demonstrate a past history of directional mating. Am J Phys Anthropol 102:153-9

Merriwether DA, Reed DM, Ferrell RE (1997b) Ancient and contemporary mitochondrial DNA variation in the Maya. In: Whittington SL, M. RD (eds) Bones of the Maya: studies of ancient skeletons. Smithsonian Institute Press, Washington, pp 208-17

Merriwether DA, Rothhammer F, Ferrell RE (1995) Distribution of the four founding lineage haplotypes in Native Americans suggests a single wave of migration for the New World. Am J Phys Anthropol 98:411-30

Mesa NR, Mondragon MC, Soto ID, Parra MV, Duque C, Ortiz-Barrientos D, Garcia LF, Velez ID, Bravo ML, Munera JG, Bedoya G, Bortolini MC, Ruiz-Linares A (2000) Autosomal, mtDNA, and Y-chromosome diversity in Amerinds: pre- and post-Columbian patterns of gene flow in South America. Am J Hum Genet 67:1277-86

Mestriner MA, Simoes AL, Salzano FM (1980) New studies on the esterase D polymorphism in South American Indians. Am J Phys Anthropol 52:95-101

Meyer D (1995) Árvores evolutivas humanas. In: Série Monografias. Vol 3. Sociedade Brasileira de Genética, Ribeirão Preto, pp 1-162

Mishmar D, Ruiz-Pesini E, Golik P, Macaulay V, Clark AG, Hosseini S, Brandon M, Easley K, Chen E, Brown MD, Sukernik RI, Olckers A, Wallace DC (2003) Natural selection shaped regional mtDNA variation in humans. Proc Natl Acad Sci U S A 100:171-6

Mohrenweiser H, Neel JV, Mestriner MA, Salzano FM, Migliazza E, Simoes AL, Yoshihara CM (1979) Electrophoretic variants in three Amerindian tribes: the Baniwa, Kanamari, and Central Pano of western Brazil. Am J Phys Anthropol 50:237-46

Monsalve MV, Cardenas F, Guhl F, Delaney AD, Devine DV (1996) Phylogenetic analysis of mtDNA lineages in South American mummies. Ann Hum Genet 60:293-303

Monsalve MV, Groot de Restrepo H, Espinel A, Correal G, Devine DV (1994) Evidence of mitochondrial DNA diversity in South American aboriginals. Ann Hum Genet 58:265-73 
Monsalve MV, Hagelberg E (1997) Mitochondrial DNA polymorphisms in Carib people of Belize. Proc R Soc Lond B Biol Sci 264:1217-24

Moraga M, Aspillaga E, Santoro C, Standen V, Carvallo P, Rothhammer F (2001) mtDNA analysis of mummies from northern Chile endorse the hypothesis of an Amazonian origin of Andean populations. Rev Chil Hist Nat 74:719-26

Moraga M, Santoro CM, Standen VG, Carvallo P, Rothhammer F (2004) Microevolution in prehistoric Andean populations: chronologic mtDNA variation in the desert valleys of northern Chile. Am J Phys Anthropol - In press

Moraga ML, Rocco P, Miquel JF, Nervi F, Llop E, Chakraborty R, Rothhammer F, Carvallo P (2000) Mitochondrial DNA polymorphisms in Chilean aboriginal populations: implications for the peopling of the southern cone of the continent. Am J Phys Anthropol 113:19-29

Moran PAP (1950) Notes on continuous stochastic phenomena. Biometrika 37:17-23

Mullis K, Faloona F, Scharf S, Saiki R, Horn G, Erlich H (1986) Specific enzymatic amplification of DNA in vitro: the polymerase chain reaction. Cold Spring Harb Symp Quant Biol 51:263-73

Neel JV, Gershowitz H, Mohrenweiser HW, Amos B, Kostyu DD, Salzano FM, Mestriner MA, Lawrence D, Simoes AL, Smouse PE, Oliver WJ, Spielman RS, Neel JV, Jr. (1980) Genetic studies on the Ticuna, an enigmatic tribe of Central Amazonas. Ann Hum Genet 44:37-54

Nei M (1987) Molecular evolutionary genetics. Columbia University Press, New York

Oden NL (1984) Assessing the significance of a spatial correlogram. Geogr Anal 16:1-16

Oliveira SF (1999) Inserções Alu recentes em indígenas da Amazônia brasileira. Tese Doutorado apresentada à Faculdade de Medicina de Ribeirão Preto, da Universidade de São Paulo

Oota H, Settheetham-Ishida W, Tiwawech D, Ishida T, Stoneking M (2001) Human mtDNA and Y-chromosome variation is correlated with matrilocal versus patrilocal residence. Nat Genet 29:20-1

O'Rourke DH, Hayes MG, Carlyle SW (2000) Spatial and temporal stability of mtDNA haplogroup frequencies in native North America. Hum Biol 72:15-34

O'Rourke DH, Mobarry A, Suarez BK (1992) Patterns of genetic variation in Native America. Hum Biol 64:417-34

Parr RL, Carlyle SW, O'Rourke DH (1996) Ancient DNA analysis of Fremont Amerindians of the Great Salt Lake Wetlands. Am J Phys Anthropol 99:507-18

Pena SD, Santos FR, Bianchi NO, Bravi CM, Carnese FR, Rothhammer F, Gerelsaikhan T, Munkhtuja B, Oyunsuren T (1995) A major founder Y-chromosome haplotype in Amerindians. Nat Genet 11:15-6 
Quintana-Murci L, Semino O, Poloni ES, Liu A, Van Gijn M, Passarino G, Brega A, Nasidze IS, Maccioni L, Cossu G, al-Zahery N, Kidd JR, Kidd KK, Santachiara-Benerecetti AS (1999) Y-chromosome specific YCAII, DYS19 and YAP polymorphisms in human populations: a comparative study. Ann Hum Genet 63:153-66

Raymond M, Rousset F (1995) An exact test for population differentiation. Evolution 49:1280-3

Reidla M, Kivisild T, Metspalu E, Kaldma K, Tambets K, Tolk HV, Parik J, Loogvali EL, Derenko M, Malyarchuk B, Bermisheva M, Zhadanov S, Pennarun E, Gubina M, Golubenko M, Damba L, Fedorova S, Gusar V, Grechanina E, Mikerezi I, Moisan JP, Chaventre A, Khusnutdinova E, Osipova L, Stepanov V, Voevoda M, Achilli A, Rengo C, Rickards O, De Stefano GF, Papiha S, Beckman L, Janicijevic B, Rudan P, Anagnou N, Michalodimitrakis E, Koziel S, Usanga E, Geberhiwot T, Herrnstadt C, Howell N, Torroni A, Villems R. (2003) Origin and diffusion of mtDNA haplogroup X. Am J Hum Genet 73:1178-90

Rendine S, Piazza A, Menozzi P, Cavalli-Sforza LL (1999) A problem with synthetic maps: reply to Sokal et al. Hum Biol 71:15-25

Reynolds J, Weir BS, Cockerham CC (1983) Estimation of the coancestry coefficient: basis for a short term genetic distance. Genetics 105:767-79

Ribeiro-dos-Santos AK, Pereira JM, Lobato MR, Carvalho BM, Guerreiro JF, Batista Dos Santos SE (2002) Dissimilarities in the process of formation of Curiau, a semi-isolated Afro-Brazilian population of the Amazon region. Am J Human Biol 14:440-7

Ribeiro-dos-Santos AK, Santos SE, Machado AL, Guapindaia V, Zago MA (1996) Heterogeneity of mitochondrial DNA haplotypes in Pre-Columbian Natives of the Amazon region. Am J Phys Anthropol 101:29-37

Rickards O, Martinez-Labarga C, Lum JK, De Stefano GF, Cann RL (1999) mtDNA history of the Cayapa Amerinds of Ecuador: detection of additional founding lineages for the Native American populations. Am J Hum Genet 65:519-30

Rocco PP, Morales CG, Moraga MV, Miquel JFP, Nervi FO, Llop ER, Carvallo PS, Rothhammer FE (2002) Genetic composition of the Chilean population. Analysis of mitochondrial DNA polymorphisms. Rev Med Chile 130:125-31

Rodas C, Gelvez N, Keyeux G (2003) Mitochondrial DNA studies show asymmetrical Amerindian admixture in Afro-Colombian and Mestizo populations. Hum Biol 75:13-30

Rodriguez-Delfin LA, Rubin-de-Celis VE, Zago MA (2001) Genetic diversity in an Andean population from Peru and regional migration patterns of Amerindians in South America: data from Y chromosome and mitochondrial DNA. Hum Hered 51:97-106

Rothhammer F, Moraga M (2001) Patterns of Y-chromosome variation in South Amerindians. Am J Hum Genet 69:904-6

Rothhammer F, Moraga M, Rivera M, Santoro CM, Standen VG, Garcia F, Carvallo P (2003) mtDNA analysis of skeletal remains from the archeological site of Tiwanaku and its relation to the origin of its builders. Chungara 35:269-74 
Rubicz R, Schurr TG, Babb PL, Crawford MH (2003) Mitochondrial DNA variation and the origins of the Aleuts. Hum Biol 75:809-35

Ruiz Linares A (1999) Microsatellites and the reconstruction of the history of human populations. In: Goldstein DB, Schlötterer (eds) Microsatellites - Evolution and Applications. Oxford University Press, Oxford, pp 183-97

Saillard J, Forster P, Lynnerup N, Bandelt HJ, Norby S (2000) mtDNA variation among Greenland Eskimos: the edge of the Beringian expansion. Am J Hum Genet 67:718-26

Salzano FM (2002) Molecular variability in Amerindians: widespread but uneven information. An Acad Bras Cienc 74:223-63

Salzano FM, Callegari-Jacques SM (1988) South american indians: a case study in evolution. Oxford University Press, New York

Salzano FM, Callegari-Jacques SM, Neel JV (1980) Genetic demography of the Amazonian Ticuna indians. J Hum Evol 9:179-91

Salzano FM, Jacques SM (1979) Genetic demography of the Central Pano and Kanamari Indians of Brazil. Hum Biol 51:551-64

Sanguinetti CJ, Dias Neto E, Simpson AJ (1994) Rapid silver staining and recovery of PCR products separated on polyacrylamide gels. Biotechniques 17:914-21

Santos FR, Pandya A, Tyler-Smith C, Pena SD, Schanfield M, Leonard WR, Osipova L, Crawford MH, Mitchell RJ (1999) The central Siberian origin for native American Y chromosomes. Am J Hum Genet 64:619-28

Santos FR, Rodriguez-Delfin L, Pena SD, Moore J, Weiss KM (1996) North and South Amerindians may have the same major founder Y chromosome haplotype [letter]. Am $\mathrm{J}$ Hum Genet 58:1369-70

Santos M, Ward RH, Barrantes R (1994) mtDNA variation in the Chibcha Amerindian Huetar from Costa Rica. Hum Biol 66:963-77

Santos SEB (1996) Ameríndios sul-americanos: quatro haplogrupos de DNA mitocondrial, múltiplos haplótipos fundadores. Tese de Doutorado apresentada à Faculdade de Medicina de Ribeirão Preto, da Universidade de São Paulo

Scheffler IE (1999) Mitochondria. Wiley-Liss, New York

Schmitt R, Bonatto SL, Freitas LB, Muschner VC, Hill K, Hurtado AM, Salzano FM (2004) Extremely limited mitochondrial DNA variability among the Ache Natives of Paraguay. Ann Hum Biol 31:87-94

Schmitz PI (1983) Mecanismos das migrações paleoindígenas na América Tropical. 1. O território nacional, menos os três estados sulinos. Comun., XXXV Reunião An Soc Bras Progr Ciência, Belém, PA:1-10 
Schneider S, Roessli D, Excoffier L (2000) Arlequin ver. 2000: a software for population genetics data analysis. Genetics and Biometry Laboratory, University of Geneva, Switzerland

Schurr TG (2004) The peopling of the New World: perspectives from molecular anthropology. Ann Rev Anthropol 33:551-83

Schurr TG, Ballinger SW, Gan YY, Hodge JA, Merriwether DA, Lawrence DN, Knowler WC, Weiss KM, Wallace DC (1990) Amerindian mitochondrial DNAs have rare Asian mutations at high frequencies, suggesting they derived from four primary maternal lineages. Am J Hum Genet 46:613-23

Schurr TG, Sherry ST (2004) Mitochondrial DNA and Y chromosome diversity and the peopling of the Americas: evolutionary and demographic evidence. Am J Hum Biol $16: 420-39$

Schwartz M, Vissing J (2002) Paternal inheritance of mitochondrial DNA. N Engl J Med 347:576-80

Scozzari R, Cruciani F, Santolamazza P, Sellitto D, Cole DE, Rubin LA, Labuda D, Marini E, Succa V, Vona G, Torroni A (1997) mtDNA and Y chromosome-specific polymorphisms in modern Ojibwa: implications about the origin of their gene pool. Am J Hum Genet $60: 241-4$

Seielstad M (2000) Asymmetries in the maternal and paternal genetic histories of Colombian populations. Am J Hum Genet 67:1062-6

Seielstad M, Yuldasheva N, Singh N, Underhill P, Oefner P, Shen P, Wells RS (2003) A novel Y-chromosome variant puts an upper limit on the timing of first entry into the Americas. Am J Hum Genet 73:700-5

Seielstad MT, Minch E, Cavalli-Sforza LL (1998) Genetic evidence for a higher female migration rate in humans. Nat Genet 20:278-80

Shields GF, Schmiechen AM, Frazier BL, Redd A, Voevoda MI, Reed JK, Ward RH (1993) mtDNA sequences suggest a recent evolutionary divergence for Beringian and northern North American populations. Am J Hum Genet 53:549-62

Silva WA, Jr., Bonatto SL, Holanda AJ, Ribeiro-Dos-Santos AK, Paixao BM, Goldman GH, Abe-Sandes K, Rodriguez-Delfin L, Barbosa M, Paco-Larson ML, Petzl-Erler ML, Valente V, Santos SE, Zago MA (2002) Mitochondrial genome diversity of Native Americans supports a single early entry of founder populations into America. Am J Hum Genet 71:187-92

Simões AL (1980) O polimorfismo da esterase D em indígenas sul-americanos. Tese Doutorado apresentada à Faculdade de Medicina de Ribeirão Preto, da Universidade de São Paulo

Slate J, Gemmell NJ (2004) Eve ' $n$ ' Steve: recombination of human mitochondrial DNA. Trends Ecol Evol 19:561-3 
Smith DG, Malhi RS, Eshleman J, Lorenz JG, Kaestle FA (1999) Distribution of mtDNA haplogroup X among Native North Americans. Am J Phys Anthropol 110:271-84

Smouse PE, Peakall R (1999) Spatial autocorrelation analysis of individual multiallele and multilocus genetic structure. Heredity 82:561-73

Sokal RR, Jacquez GM, Wooten MC (1989) Spatial autocorrelation analysis of migration and selection. Genetics 121:845-55

Sokal RR, Oden NL (1978) Spatial autocorrelation in biology .1. Methodology. Biol J Linn Soc 10:199-228

Sokal RR, Oden NL, Thomson BA (1999) A problem with synthetic maps. Hum Biol 71:1-13

Sokal RR, Wartenberg DE (1983) A test of spatial auto-correlation analysis using an isolation-by-distance model. Genetics 105:219-37

Starikovskaya YB, Sukernik RI, Schurr TG, Kogelnik AM, Wallace DC (1998) mtDNA diversity in Chukchi and Siberian Eskimos: implications for the genetic history of Ancient Beringia and the peopling of the New World. Am J Hum Genet 63:1473-91

Stone AC, Stoneking M (1993) Ancient DNA from a pre-Columbian Amerindian population. Am J Phys Anthropol 92:463-71

Stone AC, Stoneking M (1998) mtDNA analysis of a prehistoric Oneota population: implications for the peopling of the New World. Am J Hum Genet 62:1153-70

Stone AC, Stoneking M (1999) Analysis of ancient DNA from a prehistoric Amerindian cemetery. Philos Trans R Soc Lond B Biol Sci 354:153-9

Szathmary EJ (1993a) Genetics of aboriginal North Americans. Evol Anthropol 1:202-20

Szathmary EJ (1993b) mtDNA and the peopling of the Americas. Am J Hum Genet 53:793-9

Tarazona-Santos E, Carvalho-Silva DR, Pettener D, Luiselli D, De Stefano GF, Labarga CM, Rickards O, Tyler-Smith C, Pena SD, Santos FR (2001a) Genetic differentiation in South Amerindians is related to environmental and cultural diversity: evidence from the $\mathrm{Y}$ chromosome. Am J Hum Genet 68:1485-96

Tarazona-Santos E, Carvalho-Silva DR, Pettener D, Luiselli D, De Stefano GF, MartinezLabarga C, Rickards O, Tyler-Smith C, Pena SDJ, Santos FR (2001b) Reply to Rothhammer and Moraga. Am J Hum Genet 69:904-6

Toro-Labrador G, Wever OR, Martinez-Cruzado JC (2003) Mitochondrial DNA analysis in Aruba: strong maternal ancestry of closely related Amerindians and implications for the peopling of northwestern Venezuela. Carib J Sci 39:11-22

Torroni A, Chen YS, Semino O, Santachiara-Beneceretti AS, Scott CR, Lott MT, Winter M, Wallace DC (1994a) mtDNA and Y-chromosome polymorphisms in four Native American populations from southern Mexico. Am J Hum Genet 54:303-18 
Torroni A, Neel JV, Barrantes R, Schurr TG, Wallace DC (1994b) Mitochondrial DNA "clock" for the Amerinds and its implications for timing their entry into North America. Proc Natl Acad Sci U S A 91:1158-62

Torroni A, Schurr TG, Cabell MF, Brown MD, Neel JV, Larsen M, Smith DG, Vullo CM, Wallace DC (1993) Asian affinities and continental radiation of the four founding Native American mtDNAs. Am J Hum Genet 53:563-90

Torroni A, Schurr TG, Yang CC, Szathmary EJ, Williams RC, Schanfield MS, Troup GA, Knowler WC, Lawrence DN, Weiss KM, Wallace DC (1992) Native American mitochondrial DNA analysis indicates that the Amerind and the Nadene populations were founded by two independent migrations. Genetics 130:153-62

Underhill PA, Jin L, Zemans R, Oefner PJ, Cavalli-Sforza LL (1996) A pre-Columbian Y chromosome-specific transition and its implications for human evolutionary history. Proc Natl Acad Sci U S A 93:196-200

Vieira AR, Karras JC, Orioli IM, Castilla EE, Murray JC (2002) Genetic origins in a South American clefting population. Clin Genet 62:458-63

Vona G, Falchi A, Moral P, Calo CM, Varesi L (2004) Mitochondrial sequence variation in the Guahibo Amerindian population from Venezuela. Am J Phys Anthropol - In press

Wallace DC (1995) Mitochondrial DNA variation in human evolution, degenerative disease, and aging. Am J Hum Genet 57:201-23

Wallace DC, Garrison K, Knowler WC (1985) Dramatic founder effects in Amerindian mitochondrial DNAs. Am J Phys Anthropol 68:149-55

Wallace DC, Torroni A (1992) American Indian prehistory as written in the mitochondrial DNA: a review. Hum Biol 64:403-16

Wanderley-Santos LM (2001) STRs autossômicos e ligados ao cromossomo Y em indígenas brasileiros. Tese de Doutorado apresentada à Faculdade de Medicina de Ribeirão Preto, da Universidade de São Paulo

Wanderley-Santos LM, Sousa SMB, Oliveira SF, Mendes-Junior CT, Leboute APM, Simões AL (2005) Genetic diversity of Y-specific STRs in indigenous populations of the Brazilian Amazon. Hum Biol (Submetido)

Ward RH, Frazier BL, Dew-Jager K, Paabo S (1991) Extensive mitochondrial diversity within a single Amerindian tribe. Proc Natl Acad Sci U S A 88:8720-4

Ward RH, Redd A, Valencia D, Frazier B, Paabo S (1993) Genetic and linguistic differentiation in the Americas. Proc Natl Acad Sci U S A 90:10663-7

Ward RH, Salzano FM, Bonatto SL, Hutz MH, Coimbra CEA, Santos RV (1996) Mitochondrial DNA polymorphism in three Brazilian Indian tribes. Am J Hum Biol $8: 317-23$

Weir B, Cockerham CC (1984) Estimating F-statistics for the analysis of population structure. Evolution 38:1358-70 
Wilder JA, Kingan SB, Mobasher Z, Pilkington MM, Hammer MF (2004) Global patterns of human mitochondrial DNA and Y-chromosome structure are not influenced by higher migration rates of females versus males. Nat Genet 36:1122-5

Williams SR, Chagnon NA, Spielman RS (2002) Nuclear and mitochondrial genetic variation in the Yanomamo: a test case for ancient DNA studies of prehistoric populations. Am J Phys Anthropol 117:246-59

Wright S (1943) Isolation by distance. Genetics 28:114-38

Zegura SL, Karafet TM, Zhivotovsky LA, Hammer MF (2004) High-resolution SNPs and microsatellite haplotypes point to a single, recent entry of Native American $Y$ chromosomes into the Americas. Mol Biol Evol 21:164-75 
Apêndice A - Freqüências dos haplogrupos de mtDNA, localização geográfica e afiliações lingüísticas das populações do continente americano já estudadas.

\begin{tabular}{|c|c|c|c|c|c|c|c|c|c|c|c|c|c|c|}
\hline \multirow{2}{*}{ Cód. ${ }^{l}$} & \multirow{2}{*}{ População } & \multirow{2}{*}{ Aldeia - País } & \multirow{2}{*}{$n^{2}$} & \multicolumn{6}{|c|}{ Haplogrupos } & \multirow{2}{*}{$\begin{array}{l}\text { Longi- } \\
\text { tude }\end{array}$} & \multirow{2}{*}{$\begin{array}{l}\text { Lati- } \\
\text { tude }\end{array}$} & \multirow{2}{*}{$\begin{array}{l}\text { Afiliação } \\
\text { lingüistica }^{5}\end{array}$} & \multirow{2}{*}{$\begin{array}{l}\text { Área } \\
\text { geográfica }\end{array}$} & \multirow{2}{*}{ Ref. $^{7}$} \\
\hline & & & & $A$ & $B$ & $C$ & $D$ & $X$ & $?^{3}$ & & & & & \\
\hline N001 & Anasazi & Ancient - EUA & 27 & 6 & 15 & 4 & 0 & 0 & 2 & 109,30 & $36,30 \mathrm{~N}$ & Grupos Antigos & $\mathrm{AmN}, \mathrm{S} / \mathrm{GB}$ & 15 \\
\hline N002 & Ciboneys & Ancient - Cuba & 15 & 1 & 0 & 9 & 5 & 0 & 0 & 83,00 & $22,42 \mathrm{~N}$ & Grupos Antigos & $\mathrm{AmC}, \mathrm{Car}$ & 45 \\
\hline N003 & Fremont & Ancient - EUA & 30 & 0 & 22 & 4 & 2 & 0 & 2 & 112,10 & $41,22 \mathrm{~N}$ & Grupos Antigos & AmN,S/GB & 67 \\
\hline N004 & Oneota & Ancient - EUA & 108 & 34 & 13 & 46 & 9 & 0 & 6 & 89,28 & $40,04 \mathrm{~N}$ & Grupos Antigos & AmN,L/GP & 85 \\
\hline N005 & Vantage & Ancient - EUA & 7 & 2 & 0 & 1 & 3 & 1 & 0 & 120,00 & $47,00 \mathrm{~N}$ & Grupos Antigos & AmN,Noe & 51 \\
\hline N006 & Aleuts & Ancient - EUA & 17 & 6 & 0 & 0 & 11 & 0 & 0 & 162,00 & $55,30 \mathrm{~N}$ & $\mathrm{EA}, \mathrm{Al}, \mathrm{Al}$ & AmN,Art & 66 \\
\hline N007 & Aleuts & Ilha Commander - Rússia & 30 & 0 & 0 & 0 & 30 & 0 & 0 & 193,39 & $54,58 \mathrm{~N}$ & $\mathrm{EA}, \mathrm{Al}, \mathrm{Al}$ & AmN,Art & 24 \\
\hline N008 & Aleuts & Várias - EUA & 179 & 51 & 0 & 0 & 128 & 0 & 0 & 162,16 & $55,18 \mathrm{~N}$ & $\mathrm{EA}, \mathrm{Al}, \mathrm{Al}$ & AmN,Art & 75 \\
\hline N009 & Aleuts & Saint Paul - EUA & 72 & 18 & 0 & 1 & 48 & 0 & 5 & 170,16 & $57,12 \mathrm{~N}$ & $\mathrm{EA}, \mathrm{Al}, \mathrm{Al}$ & AmN,Art & 54 \\
\hline N010 & Eskimo & Gambell - EUA & 50 & 29 & 0 & 7 & 13 & 0 & 1 & 169,37 & $63,16 \mathrm{~N}$ & $\mathrm{EA}, \mathrm{Es}, \mathrm{Yu}$ & AmN,Art & 54 \\
\hline N011 & Eskimo & Old Harbor - EUA & 115 & 71 & 4 & 0 & 40 & 0 & 0 & 153,05 & $57,41 \mathrm{~N}$ & $\mathrm{EA}, \mathrm{Es}, \mathrm{Yu}$ & AmN,Art & 54 \\
\hline N012 & Eskimo & Ouzinkie - EUA & 41 & 30 & 0 & 2 & 6 & 0 & 3 & 154,18 & $57,24 \mathrm{~N}$ & $\mathrm{EA}, \mathrm{Es}, \mathrm{Yu}$ & AmN,Art & 54 \\
\hline N013 & Eskimo & Savoonga - EUA & 49 & 46 & 0 & 0 & 1 & 0 & 2 & 171,15 & $63,31 \mathrm{~N}$ & $\mathrm{EA}, \mathrm{Es}, \mathrm{Yu}$ & AmN,Art & 54 \\
\hline N014 & Eskimo & Yupik - EUA & 165 & 43 & 0 & 3 & 106 & 0 & 13 & 161,12 & $59,40 \mathrm{~N}$ & EA,Es, Yu & AmN,Art & 56 \\
\hline N015 & Eskimo & Inuit - Canadá & 30 & 29 & 0 & 0 & 1 & 0 & 0 & 134,44 & $68,30 \mathrm{~N}$ & EA,Es,In & AmN,Art & 47 \\
\hline N016 & Eskimo & Ammassalik - Groenlândia & 10 & 10 & 0 & 0 & 0 & 0 & 0 & 35,13 & $67,05 \mathrm{~N}$ & EA,Es,In & AmN,Art & 76 \\
\hline N017 & Eskimo & Ilulissat - Groenlândia & 15 & 15 & 0 & 0 & 0 & 0 & 0 & 50,19 & $68,27 \mathrm{~N}$ & EA,Es,In & AmN,Art & 76 \\
\hline N018 & Eskimo & $\begin{array}{l}\text { Ittoqqortoormiit - } \\
\text { Groenlândia }\end{array}$ & 15 & 15 & 0 & 0 & 0 & 0 & 0 & 23,40 & $71,30 \mathrm{~N}$ & EA,Es,In & AmN,Art & 76 \\
\hline N019 & Eskimo & Nanortalik - Groenlândia & 5 & 5 & 0 & 0 & 0 & 0 & 0 & 44,54 & $61,28 \mathrm{~N}$ & EA,Es,In & AmN,Art & 76 \\
\hline N020 & Eskimo & Nuuk - Groenlândia & 15 & 15 & 0 & 0 & 0 & 0 & 0 & 49,53 & $63,48 \mathrm{~N}$ & EA,Es,In & AmN,Art & 76 \\
\hline N021 & Eskimo & Upernavik - Groenlândia & 11 & 11 & 0 & 0 & 0 & 0 & 0 & 53,27 & $72,57 \mathrm{~N}$ & EA,Es,In & AmN,Art & 76 \\
\hline N022 & Eskimo & Uummannaq - Groenlândia & 11 & 11 & 0 & 0 & 0 & 0 & 0 & 50,41 & $70,22 \mathrm{~N}$ & EA,Es,In & AmN,Art & 76 \\
\hline N023 & Tlingits & EUA & 2 & 2 & 0 & 0 & 0 & 0 & 0 & & & & & 87 \\
\hline N024 & Haida (1) & Canadá & 29 & 28 & 0 & 0 & 1 & 0 & 0 & 132,48 & $53,51 \mathrm{~N}$ & $\mathrm{ND}, \mathrm{Ha}, \mathrm{Ha}$ & AmN,Noe & 47,88 \\
\hline N025 & Haida (2) & Canadá & 38 & 35 & 0 & 3 & 0 & 0 & 0 & 131,49 & $52,59 \mathrm{~N}$ & $\mathrm{ND}, \mathrm{Ha}, \mathrm{Ha}$ & AmN,Noe & 54,93 \\
\hline N026 & Apache & EUA & 180 & 125 & 35 & 16 & 0 & 1 & 3 & 112,04 & $33,32 \mathrm{~N}$ & $\mathrm{ND}, \mathrm{Co}, \mathrm{AE}$ & AmN,S/GB & 14 \\
\hline N027 & Apache & San Carlos - EUA & 38 & 24 & 5 & 7 & 2 & 0 & 0 & 110,10 & $35,46 \mathrm{~N}$ & $\mathrm{ND}, \mathrm{Co}, \mathrm{AE}$ & AmN,S/GB & $47,50,88$ \\
\hline N028 & Dogrib (1) & Canadá & 154 & 140 & 0 & 3 & 0 & 0 & 11 & 118,03 & $64,17 \mathrm{~N}$ & $\mathrm{ND}, \mathrm{Co}, \mathrm{AE}$ & AmN,Art & 54 \\
\hline N029 & Dogrib (2) & Canadá & 42 & 42 & 0 & 0 & 0 & 0 & 0 & 128,28 & $62,36 \mathrm{~N}$ & $\mathrm{ND}, \mathrm{Co}, \mathrm{AE}$ & AmN,Art & 47,87 \\
\hline N030 & Hupa & EUA & 2 & 0 & 2 & 0 & 0 & 0 & 0 & & & & & 47 \\
\hline N031 & Navajo (1) & EUA & 146 & 68 & 63 & 11 & 2 & 1 & 1 & 112,00 & $33,30 \mathrm{~N}$ & $\mathrm{ND}, \mathrm{Co}, \mathrm{AE}$ & AmN,S/GB & 14 \\
\hline N032 & Navajo (2) & EUA & 64 & 33 & 26 & 3 & 0 & 2 & 0 & 113,57 & $36,39 \mathrm{~N}$ & $\mathrm{ND}, \mathrm{Co}, \mathrm{AE}$ & AmN,S/GB & $\begin{array}{c}47,50,87 \\
\text { continua) }\end{array}$ \\
\hline
\end{tabular}




\section{Apêndice A (continuação)}

\begin{tabular}{|c|c|c|c|c|c|c|c|c|c|c|c|c|c|c|}
\hline \multirow{2}{*}{ Cód. ${ }^{l}$} & \multirow{2}{*}{ População } & \multirow{2}{*}{ Aldeia - País } & \multirow{2}{*}{$n^{2}$} & \multicolumn{6}{|c|}{ Haplogrupos } & \multirow{2}{*}{$\begin{array}{l}\text { Longi- } \\
\text { tude }\end{array}$} & \multirow{2}{*}{$\begin{array}{l}\text { Lati- } \\
\text { tude }\end{array}$} & \multirow{2}{*}{$\begin{array}{l}\text { Afiliação } \\
\text { lingüística }^{5}\end{array}$} & \multirow{2}{*}{$\begin{array}{l}\text { Área } \\
\text { geográfica }^{6}\end{array}$} & \multirow{2}{*}{ Ref. $^{7}$} \\
\hline & & & & $A$ & $B$ & $C$ & $D$ & $X$ & $?^{3}$ & & & & & \\
\hline N033 & Bella Coola (1) & Canadá & 36 & 18 & 2 & 5 & 9 & 0 & 2 & 129,15 & $55,17 \mathrm{~N}$ & $\mathrm{Am}, \mathrm{NA}, \mathrm{AK}$ & AmN,Noe & 88 \\
\hline N034 & Bella Coola (2) & Canadá & 32 & 25 & 2 & 3 & 2 & 0 & 0 & 128,12 & $53,11 \mathrm{~N}$ & $\mathrm{Am}, \mathrm{NA}, \mathrm{AK}$ & AmN,Noe & 54,93 \\
\hline N035 & Cheyenne/Arapahoe & EUA & 35 & 12 & 4 & 12 & 5 & 2 & 0 & 103,47 & $43,22 \mathrm{~N}$ & $\mathrm{Am}, \mathrm{NA}, \mathrm{AK}$ & $\mathrm{AmN}, \mathrm{L} / \mathrm{GP}$ & $47,49,83$ \\
\hline N036 & Chippewa & $\begin{array}{l}\text { Hayward e Turtle } \\
\text { Mountain - EUA }\end{array}$ & 15 & 4 & 2 & 5 & 0 & 0 & 4 & 92,45 & $45,42 \mathrm{~N}$ & Am,NA,AK & AmN,L/GP & 88 \\
\hline N037 & Chippewa & Hayward - EUA & 62 & 17 & 3 & 22 & 2 & 18 & 0 & 90,56 & $46,06 \mathrm{~N}$ & $\mathrm{Am}, \mathrm{NA}, \mathrm{AK}$ & $\mathrm{AmN}, \mathrm{L} / \mathrm{GP}$ & 49 \\
\hline N038 & Chippewa & Turtle Mountain - EUA & 28 & 16 & 5 & 5 & 0 & 2 & 0 & 103,00 & $48,15 \mathrm{~N}$ & $\mathrm{Am}, \mathrm{NA}, \mathrm{AK}$ & $\mathrm{AmN}, \mathrm{L} / \mathrm{GP}$ & 49 \\
\hline N039 & Chippewa/Kickapoo & EUA & 19 & 8 & 4 & 5 & 0 & 0 & 2 & 93,51 & $47,03 \mathrm{~N}$ & $\mathrm{Am}, \mathrm{NA}, \mathrm{AK}$ & $\mathrm{AmN}, \mathrm{L} / \mathrm{GP}$ & 47 \\
\hline N040 & $\begin{array}{l}\text { Micmac/ } \\
\text { Narragansett }\end{array}$ & Eskasoni - Canadá & 7 & 2 & 0 & 1 & 0 & 0 & 4 & & & & & 47 \\
\hline N041 & Nuu-Chah-Nulth (1) & Canadá & 63 & 28 & 2 & 12 & 14 & 7 & 0 & 127,00 & $50,28 \mathrm{~N}$ & $\mathrm{Am}, \mathrm{NA}, \mathrm{AK}$ & AmN,Noe & $13,84,92$ \\
\hline N042 & Nuu-Chah-Nulth (2) & Canadá & 15 & 6 & 1 & 2 & 4 & 2 & 0 & 126,08 & $50,04 \mathrm{~N}$ & $\mathrm{Am}, \mathrm{NA}, \mathrm{AK}$ & AmN,Noe & 13,88 \\
\hline N043 & Ojibwa (Northern) & Canadá & 28 & 18 & 1 & 2 & 0 & 7 & 0 & 84,00 & $48,45 \mathrm{~N}$ & $\mathrm{Am}, \mathrm{NA}, \mathrm{AK}$ & $\mathrm{AmN}, \mathrm{L} / \mathrm{GP}$ & 81,88 \\
\hline N044 & Ojibwa (Southern) & Ilha Manitoulin - Canadá & 35 & 11 & 3 & 9 & 1 & 9 & 2 & 82,09 & $45,45 \mathrm{~N}$ & $\mathrm{Am}, \mathrm{NA}, \mathrm{AK}$ & $\mathrm{AmN}, \mathrm{L} / \mathrm{GP}$ & 81 \\
\hline N045 & Plateu Salish & Ancient - EUA & 11 & 3 & 6 & 1 & 1 & 0 & 0 & 119,00 & $48,00 \mathrm{~N}$ & $\mathrm{Am}, \mathrm{NA}, \mathrm{AK}$ & AmN,Noe & 51 \\
\hline N046 & Yurok & EUA & 1 & 0 & 1 & 0 & 0 & 0 & 0 & & & & & 47 \\
\hline N047 & Acoma & EUA & 1 & 1 & 0 & 0 & 0 & 0 & 0 & & & & & 47 \\
\hline N048 & Cherokee & EUA & 16 & 0 & 5 & 5 & 0 & 0 & 6 & 82,04 & $35,54 \mathrm{~N}$ & $\mathrm{Am}, \mathrm{NA}, \mathrm{AK}$ & $\mathrm{AmN}, \mathrm{L} / \mathrm{GP}$ & 47 \\
\hline N049 & Cherokee & Oklahoma red cross - EUA & 19 & 4 & 4 & 10 & 1 & 0 & 0 & 95,55 & $36,09 \mathrm{~N}$ & Am,NA,AK & AmN,L/GP & 49 \\
\hline N050 & Cherokee & Stillwell - EUA & 37 & 4 & 17 & 16 & 0 & 0 & 0 & 83,00 & $35,39 \mathrm{~N}$ & $\mathrm{Am}, \mathrm{NA}, \mathrm{AK}$ & AmN,L/GP & 49 \\
\hline N051 & Mohawk & Canadá & 181 & 84 & 19 & 25 & 1 & 0 & 52 & 74,24 & $49,22 \mathrm{~N}$ & $\mathrm{Am}, \mathrm{NA}, \mathrm{AK}$ & $\mathrm{AmN}, \mathrm{L} / \mathrm{GP}$ & 54 \\
\hline N052 & Mohawk & EUA & 123 & 71 & 21 & 29 & 2 & 0 & 0 & 77,41 & $39,46 \mathrm{~N}$ & $\mathrm{Am}, \mathrm{NA}, \mathrm{AK}$ & $\mathrm{AmN}, \mathrm{L} / \mathrm{GP}$ & 49,55 \\
\hline N053 & Pawnee & EUA & 5 & 2 & 3 & 0 & 0 & 0 & 0 & 98,45 & $42,55 \mathrm{~N}$ & $\mathrm{Am}, \mathrm{NA}, \mathrm{AK}$ & $\mathrm{AmN}, \mathrm{L} / \mathrm{GP}$ & 47,49 \\
\hline N054 & Siouan & EUA & 34 & 18 & 6 & 5 & 2 & 0 & 3 & 97,49 & $42,55 \mathrm{~N}$ & $\mathrm{Am}, \mathrm{NA}, \mathrm{AK}$ & AmN,L/GP & 47 \\
\hline N055 & Sioux & Sisseton, Wapheton - EUA & 45 & 25 & 9 & 8 & 2 & 1 & 0 & 103,57 & $48,06 \mathrm{~N}$ & $\mathrm{Am}, \mathrm{NA}, \mathrm{AK}$ & $\mathrm{AmN}, \mathrm{L} / \mathrm{GP}$ & 49 \\
\hline N056 & California Penutian & EUA & 17 & 2 & 7 & 1 & 7 & 0 & 0 & 122,52 & $41,20 \mathrm{~N}$ & $\mathrm{Am}, \mathrm{NA}, \mathrm{Pe}$ & $\mathrm{AmN}, \mathrm{S} / \mathrm{GB}$ & 47 \\
\hline N057 & Pyramid Lake & Ancient - EUA & 18 & 2 & 6 & 0 & 10 & 0 & 0 & 118,57 & $39,52 \mathrm{~N}$ & $\mathrm{Am}, \mathrm{NA}, \mathrm{Pe}$ & $\mathrm{AmN}, \mathrm{S} / \mathrm{GB}$ & 39 \\
\hline N058 & Stillwater Marsh & Ancient - EUA & 21 & 1 & 8 & 0 & 12 & 0 & 0 & 118,57 & $39,52 \mathrm{~N}$ & Am,NA,Pe & AmN,S/GB & 39 \\
\hline N059 & Coos & EUA & 1 & 0 & 0 & 1 & 0 & 0 & 0 & & & & & 47 \\
\hline N060 & Mixe & Ayutla - México & 16 & 10 & 5 & 1 & 0 & 0 & 0 & 96,03 & $17,06 \mathrm{~N}$ & $\mathrm{Am}, \mathrm{NA}, \mathrm{Pe}$ & AmC,Not & 89 \\
\hline N061 & Chickasaw & EUA & 8 & 1 & 6 & 1 & 0 & 0 & 0 & 89,15 & $34,50 \mathrm{~N}$ & $\mathrm{Am}, \mathrm{NA}, \mathrm{Pe}$ & $\mathrm{AmN}, \mathrm{L} / \mathrm{GP}$ & 10,47 \\
\hline N062 & Choctaw & EUA & 27 & 20 & 5 & 1 & 1 & 0 & 0 & 88,40 & $31,45 \mathrm{~N}$ & $\mathrm{Am}, \mathrm{NA}, \mathrm{Pe}$ & $\mathrm{AmN}, \mathrm{L} / \mathrm{GP}$ & 10,47 \\
\hline N063 & Creek & EUA & 39 & 14 & 6 & 8 & 11 & 0 & 0 & 85,15 & $33,25 \mathrm{~N}$ & $\mathrm{Am}, \mathrm{NA}, \mathrm{Pe}$ & $\mathrm{AmN}, \mathrm{L} / \mathrm{GP}$ & 10,47 \\
\hline N064 & Seminole & EUA & 40 & 25 & 10 & 3 & 2 & 0 & 0 & 81,50 & $28,30 \mathrm{~N}$ & $\mathrm{Am}, \mathrm{NA}, \mathrm{Pe}$ & $\mathrm{AmN}, \mathrm{L} / \mathrm{GP}$ & 10,38 \\
\hline N065 & Mvskoke & Muskogee - EUA & 71 & 26 & 11 & 7 & 27 & 0 & 0 & 95,21 & $35,45 \mathrm{~N}$ & $\mathrm{Am}, \mathrm{NA}, \mathrm{Pe}$ & AmN,L/GP & 54 \\
\hline
\end{tabular}


Apêndice A (continuação)

\begin{tabular}{|c|c|c|c|c|c|c|c|c|c|c|c|c|c|c|}
\hline \multirow{2}{*}{ Cód. ${ }^{l}$} & \multirow{2}{*}{ População } & \multirow{2}{*}{ Aldeia-País } & \multirow{2}{*}{$n^{2}$} & \multicolumn{6}{|c|}{ Haplogrupos } & \multirow{2}{*}{$\begin{array}{l}\text { Longi- } \\
\text { tude }\end{array}$} & \multirow{2}{*}{$\begin{array}{l}\text { Lati- } \\
\text { tude }\end{array}$} & \multirow{2}{*}{$\begin{array}{l}\text { Afiliação } \\
\text { lingüística }\end{array}$} & \multirow{2}{*}{$\begin{array}{l}\text { Área } \\
\text { geográfica }\end{array}$} & \multirow{2}{*}{ Ref. $^{7}$} \\
\hline & & & & $A$ & $B$ & $C$ & $D$ & $X$ & $?^{3}$ & & & & & \\
\hline N066 & Zuni & EUA & 26 & 4 & 20 & 2 & 0 & 0 & 0 & 111,46 & $36,02 \mathrm{~N}$ & Am,NA,Pe & $\mathrm{AmN}, \mathrm{S} / \mathrm{GB}$ & 47,50 \\
\hline N067 & Maya & México & 27 & 14 & 6 & 4 & 2 & 0 & 1 & 88,24 & $20,24 \mathrm{~N}$ & $\mathrm{Am}, \mathrm{NA}, \mathrm{Pe}$ & AmC,Not & 80,87 \\
\hline N068 & Maya & Ancient - Honduras & 9 & 0 & 0 & 8 & 1 & 0 & 0 & 88,46 & $14,46 \mathrm{~N}$ & $\mathrm{Am}, \mathrm{NA}, \mathrm{Pe}$ & AmC,Not & 34,58 \\
\hline N069 & Maya & Ancient - México & 25 & 21 & 1 & 2 & 0 & 0 & 1 & 87,03 & $20,51 \mathrm{~N}$ & Am,NA,Pe & AmC,Not & 34 \\
\hline N070 & Quiche & $\begin{array}{l}\text { San Jose Pachoa Lemoa - } \\
\text { Guatemala }\end{array}$ & 23 & 16 & 6 & 1 & 0 & 0 & 0 & 91,09 & $14,54 \mathrm{~N}$ & $\mathrm{Am}, \mathrm{NA}, \mathrm{Pe}$ & AmC,Not & 9 \\
\hline N071 & Plateu Sahaptian & Ancient - EUA & 8 & 0 & 4 & 2 & 2 & 0 & 0 & 118,30 & $46,30 \mathrm{~N}$ & $\mathrm{Am}, \mathrm{NA}, \mathrm{Pe}$ & AmN,Noe & 51 \\
\hline N072 & Wishram & Ancient - EUA & 33 & 7 & 17 & 0 & 9 & 0 & 0 & 120,50 & $45,50 \mathrm{~N}$ & $\mathrm{Am}, \mathrm{NA}, \mathrm{Pe}$ & AmN,Noe & 51 \\
\hline N073 & Yakima & EUA & 42 & 2 & 28 & 3 & 7 & 2 & 0 & 120,08 & $45,50 \mathrm{~N}$ & $\mathrm{Am}, \mathrm{NA}, \mathrm{Pe}$ & AmN,Noe & $13,51,82$ \\
\hline N074 & Yok-Utian & EUA & 17 & 2 & 5 & 2 & 8 & 0 & 0 & 119,30 & $36,45 \mathrm{~N}$ & Am,NA,Pe & $\mathrm{AmN}, \mathrm{S} / \mathrm{GB}$ & 27 \\
\hline N075 & Chumash & EUA & 21 & 11 & 0 & 3 & 7 & 0 & 0 & 120,20 & $34,40 \mathrm{~N}$ & Am,NA,Ho & $\mathrm{AmN}, \mathrm{S} / \mathrm{GB}$ & 27 \\
\hline N076 & Salinan/Chumash & EUA & 11 & 5 & 2 & 1 & 3 & 0 & 0 & 120,43 & $36,31 \mathrm{~N}$ & Am,NA,Ho & $\mathrm{AmN}, \mathrm{S} / \mathrm{GB}$ & 47 \\
\hline N077 & Washo & EUA & 28 & 0 & 15 & 10 & 3 & 0 & 0 & 119,00 & $38,50 \mathrm{~N}$ & Am,NA,Ho & $\mathrm{AmN}, \mathrm{S} / \mathrm{GB}$ & 47 \\
\hline N078 & Cochimi & México & 13 & 1 & 6 & 6 & 0 & 0 & 0 & 113,09 & $27,46 \mathrm{~N}$ & Am,NA,Ho & AmC,Not & 47 \\
\hline N079 & Delta Yuman & México & 23 & 0 & 13 & 10 & 0 & 0 & 0 & 115,07 & $32,15 \mathrm{~N}$ & Am,NA,Ho & $\mathrm{AmN}, \mathrm{S} / \mathrm{GB}$ & 50 \\
\hline N080 & $\begin{array}{l}\text { Havasupai/Hualapai } \\
\text { /Yavapai/Mojave }\end{array}$ & EUA & 18 & 2 & 9 & 7 & 0 & 0 & 0 & 117,12 & $38,14 \mathrm{~N}$ & Am,NA,Ho & $\mathrm{AmN}, \mathrm{S} / \mathrm{GB}$ & 47 \\
\hline N081 & Kiliwa/Paipai & México & 11 & 0 & 10 & 1 & 0 & 0 & 0 & 115,39 & $31,49 \mathrm{~N}$ & Am,NA,Ho & AmC,Not & 47 \\
\hline N082 & Kumiai & EUA & 16 & 0 & 10 & 6 & 0 & 0 & 0 & 117,52 & $34,18 \mathrm{~N}$ & Am,NA,Ho & $\mathrm{AmN}, \mathrm{S} / \mathrm{GB}$ & 47 \\
\hline N083 & Pai Yuman & EUA & 27 & 2 & 18 & 7 & 0 & 0 & 0 & 113,13 & $36,07 \mathrm{~N}$ & Am,NA,Ho & $\mathrm{AmN}, \mathrm{S} / \mathrm{GB}$ & 50 \\
\hline N084 & Quechan/Cocopa & EUA & 23 & 0 & 15 & 7 & 0 & 0 & 1 & 116,20 & $36,06 \mathrm{~N}$ & Am,NA,Ho & $\mathrm{AmN}, \mathrm{S} / \mathrm{GB}$ & 47 \\
\hline N085 & River Yuman & EUA & 22 & 0 & 14 & 8 & 0 & 0 & 0 & 114,33 & $33,49 \mathrm{~N}$ & Am,NA,Ho & $\mathrm{AmN}, \mathrm{S} / \mathrm{GB}$ & 50 \\
\hline N086 & Seri & México & 8 & 0 & 1 & 7 & 0 & 0 & 0 & 113,03 & $28,19 \mathrm{~N}$ & Am,NA,Ho & AmC,Not & 50 \\
\hline N087 & $\begin{array}{l}\text { Northern California } \\
\text { Hokan }\end{array}$ & EUA & 5 & 0 & 2 & 1 & 2 & 0 & 0 & 121,00 & $41,25 \mathrm{~N}$ & Am,NA,Ho & $\mathrm{AmN}, \mathrm{S} / \mathrm{GB}$ & 47 \\
\hline N088 & Pomo & EUA & 1 & 0 & 0 & 0 & 1 & 0 & 0 & & & & & 87 \\
\hline N089 & Kiowa & EUA & 5 & 2 & 0 & 1 & 0 & 2 & 0 & 96,39 & $36,25 \mathrm{~N}$ & $\mathrm{Am}, \mathrm{CA}, \mathrm{Ta}$ & $\mathrm{AmN}, \mathrm{L} / \mathrm{GP}$ & 47,83 \\
\hline N090 & $\begin{array}{l}\text { Jemez/Taos/San } \\
\text { Idelfonso }\end{array}$ & EUA & 36 & 0 & 32 & 1 & 0 & 3 & 0 & 109,11 & $35,28 \mathrm{~N}$ & $\mathrm{Am}, \mathrm{CA}, \mathrm{Ta}$ & $\mathrm{AmN}, \mathrm{S} / \mathrm{GB}$ & $47,50,83$ \\
\hline N091 & $\begin{array}{l}\text { Taono O'odham } \\
\text { (Papago) }\end{array}$ & EUA & 37 & 0 & 21 & 14 & 2 & 0 & 0 & 113,28 & $32,15 \mathrm{~N}$ & Am,CA,UA & $\mathrm{AmN}, \mathrm{S} / \mathrm{GB}$ & 50 \\
\hline N092 & $\begin{array}{l}\text { California Uto- } \\
\text { Aztecan }\end{array}$ & EUA & 14 & 0 & 4 & 6 & 4 & 0 & 0 & 119,41 & $35,33 \mathrm{~N}$ & Am,CA,UA & AmN,S/GB & 47 \\
\hline N093 & Comanche & EUA & 2 & 0 & 2 & 0 & 0 & 0 & 0 & & & & & 47 \\
\hline N094 & Hopi & EUA & 4 & 0 & 4 & 0 & 0 & 0 & 0 & & & & & 47,87 \\
\hline
\end{tabular}


Apêndice A (continuação)

\begin{tabular}{|c|c|c|c|c|c|c|c|c|c|c|c|c|c|c|}
\hline \multirow{2}{*}{ Cód. ${ }^{l}$} & \multirow{2}{*}{ População } & \multirow{2}{*}{ Aldeia - País } & \multirow{2}{*}{$n^{2}$} & \multicolumn{6}{|c|}{ Haplogrupos } & \multirow{2}{*}{$\begin{array}{l}\text { Longi- } \\
\text { tude }^{4}\end{array}$} & \multirow{2}{*}{$\begin{array}{l}\text { Lati- } \\
\text { tude }\end{array}$} & \multirow{2}{*}{$\begin{array}{l}\text { Afiliação } \\
\text { lingüistica }^{5}\end{array}$} & \multirow{2}{*}{$\begin{array}{l}\text { Área } \\
\text { geográfica }\end{array}$} & \multirow{2}{*}{ Ref. $^{7}$} \\
\hline & & & & $\bar{A}$ & $B$ & $C$ & $D$ & $\bar{X}$ & $?^{3}$ & & & & & \\
\hline N095 & Nahua/Cora & México & 32 & 17 & 11 & 2 & 0 & 0 & 2 & 101,11 & $21,19 \mathrm{~N}$ & $\mathrm{Am}, \mathrm{CA}, \mathrm{UA}$ & AmC,Not & 47 \\
\hline N096 & $\begin{array}{l}\text { Northern Uto- } \\
\text { Aztecan }\end{array}$ & EUA & 116 & 0 & 49 & 17 & 50 & 0 & 0 & 118,09 & $34,55 \mathrm{~N}$ & Am,CA,UA & $\mathrm{AmN}, \mathrm{S} / \mathrm{GB}$ & 39 \\
\hline N097 & Paiute/Shoshone & EUA & 9 & 0 & 2 & 2 & 4 & 0 & 1 & 120,39 & $37,54 \mathrm{~N}$ & Am,CA,UA & $\mathrm{AmN}, \mathrm{S} / \mathrm{GB}$ & 47 \\
\hline N098 & Pima & EUA & 37 & 2 & 21 & 14 & 0 & 0 & 0 & 115,02 & $33,54 \mathrm{~N}$ & $\mathrm{Am}, \mathrm{CA}, \mathrm{UA}$ & $\mathrm{AmN}, \mathrm{S} / \mathrm{GB}$ & $47,80,87$ \\
\hline N099 & Takik & EUA & 15 & 0 & 3 & 8 & 4 & 0 & 0 & 115,50 & $35,00 \mathrm{~N}$ & Am,CA,UA & $\mathrm{AmN}, \mathrm{S} / \mathrm{GB}$ & 27 \\
\hline N100 & Mixtec (Alta) & Huajuapan - México & 15 & 11 & 2 & 2 & 0 & 0 & 0 & 97,00 & $18,00 \mathrm{~N}$ & $\mathrm{Am}, \mathrm{CA}, \mathrm{OM}$ & AmC,Not & 89 \\
\hline N101 & Mixtec (Baja) & Nochixtlan - México & 14 & 13 & 1 & 0 & 0 & 0 & 0 & 97,47 & $17,49 \mathrm{~N}$ & $\mathrm{Am}, \mathrm{CA}, \mathrm{OM}$ & AmC,Not & 89 \\
\hline N102 & Zapotec & Abasolo - México & 15 & 5 & 5 & 5 & 0 & 0 & 0 & 96,45 & $16,50 \mathrm{~N}$ & $\mathrm{Am}, \mathrm{CA}, \mathrm{OM}$ & AmC,Not & 89 \\
\hline N103 & Ameríndios & $\begin{array}{l}\text { Mayagüez, Indiera Alta, } \\
\text { Indiera Baja e Miraflores - } \\
\text { Porto Rico }\end{array}$ & 56 & 22 & 2 & 15 & 0 & 0 & 17 & 66,52 & $18,10 \mathrm{~N}$ & Ameríndios & AmC,Car & 53 \\
\hline N104 & Hispânicos & San Luis Valley - EUA & 450 & 139 & 154 & 74 & 1 & 2 & 80 & 106,00 & $37,10 \mathrm{~N}$ & Hispânicos & & 57 \\
\hline N105 & Euro-descendentes & San Luis Valley - EUA & 207 & 1 & 1 & 0 & 0 & 0 & 205 & & & & & 57 \\
\hline N106 & Urbano & $\begin{array}{l}\text { Ciudad Juárez e Ojinaga - } \\
\text { México }\end{array}$ & 223 & 75 & 59 & 52 & 13 & 0 & 24 & 105,54 & $30,56 \mathrm{~N}$ & Urbano & & 35 \\
\hline N107 & Urbano & Mayagüez - Porto Rico & 38 & 11 & 3 & 6 & 0 & 0 & 18 & 67,09 & $18,13 \mathrm{~N}$ & Urbano & & 53 \\
\hline N108 & Afro-descendentes & Belize & 30 & 0 & 1 & 0 & 0 & 0 & 29 & & & & & 62 \\
\hline S001 & Bolívia & Ancient - Bolívia & 13 & 1 & 2 & 3 & 3 & 0 & 4 & 68,42 & $16,19 \mathrm{~S}$ & Grupos Antigos & AmS,And & 74 \\
\hline S002 & Brasil & Ancient - Brasil & 18 & 5 & 1 & 4 & 1 & 0 & 7 & & & & & 68 \\
\hline S003 & Chile (1) & Ancient - Chile & 61 & 16 & 21 & 9 & 2 & 0 & 13 & 70,10 & $18,30 \mathrm{~S}$ & Grupos Antigos & AmS,And & 65 \\
\hline S004 & Chile (2) & Ancient - Chile & 32 & 10 & 7 & 10 & 1 & 0 & 4 & 70,00 & $18,30 \mathrm{~S}$ & Grupos Antigos & AmS,And & 64 \\
\hline S005 & Colômbia & Ancient - Colômbia & 8 & 5 & 1 & 2 & 0 & 0 & 0 & & & & & 60,61 \\
\hline S006 & Yanomama & Brasil & 24 & 0 & 4 & 13 & 7 & 0 & 0 & 69,17 & $00,04 \mathrm{~N}$ & $\mathrm{Am}, \mathrm{CP}, \mathrm{Ch}$ & AmS,Ama & 88 \\
\hline S007 & Yanomama & Alto Mucajai - Brasil & 30 & 5 & 8 & 16 & 1 & 0 & 0 & 62,12 & $02,47 \mathrm{~N}$ & $\mathrm{Am}, \mathrm{CP}, \mathrm{Ch}$ & AmS,Ama & 78 \\
\hline S008 & Yanomama & Shamatari - Venezuela & 155 & 0 & 87 & 49 & 19 & 0 & 0 & 65,21 & $02,26 \mathrm{~N}$ & $\mathrm{Am}, \mathrm{CP}, \mathrm{Ch}$ & AmS,Ama & 95 \\
\hline S009 & Yanomama & $\begin{array}{l}\text { Surucucu e Catrimani - } \\
\text { Brasil }\end{array}$ & 83 & 0 & 5 & 60 & 8 & 0 & 10 & 62,19 & $03,49 \mathrm{~N}$ & $\mathrm{Am}, \mathrm{CP}, \mathrm{Ch}$ & AmS,Ama & 26 \\
\hline S010 & Boruca & Costa Rica & 14 & 3 & 10 & 0 & 1 & 0 & 0 & 84,30 & $10,34 \mathrm{~N}$ & $\mathrm{Am}, \mathrm{CP}, \mathrm{Ch}$ & AmC,Sul & 88 \\
\hline S011 & Bribi-Cabecar & Nicarágua & 24 & 13 & 11 & 0 & 0 & 0 & 0 & 84,30 & $14,10 \mathrm{~N}$ & $\mathrm{Am}, \mathrm{CP}, \mathrm{Ch}$ & AmC,Sul & 88 \\
\hline S012 & Chimila & Colômbia & 35 & 31 & 0 & 1 & 2 & 0 & 1 & 74,22 & $09,48 \mathrm{~N}$ & $\mathrm{Am}, \mathrm{CP}, \mathrm{Ch}$ & AmS,And & 40 \\
\hline S013 & Guane-Butaregua & Colômbia & 33 & 4 & 21 & 0 & 8 & 0 & 0 & 73,36 & $07,15 \mathrm{~N}$ & $\mathrm{Am}, \mathrm{CP}, \mathrm{Ch}$ & AmS,And & 40 \\
\hline S014 & Guatuso & Costa Rica & 20 & 17 & 3 & 0 & 0 & 0 & 0 & 83,29 & $09,34 \mathrm{~N}$ & $\mathrm{Am}, \mathrm{CP}, \mathrm{Ch}$ & AmC,Sul & 90 \\
\hline S015 & Guaymi & Panamá & 16 & 11 & 5 & 0 & 0 & 0 & 0 & 81,06 & $08,25 \mathrm{~N}$ & $\mathrm{Am}, \mathrm{CP}, \mathrm{Ch}$ & AmC,Sul & 88 \\
\hline S016 & Huetar & Quitirrisí - Costa Rica & 27 & 19 & 1 & 0 & 7 & 0 & 0 & 84,15 & $09,50 \mathrm{~N}$ & $\mathrm{Am}, \mathrm{CP}, \mathrm{Ch}$ & AmC,Sul & 77 \\
\hline
\end{tabular}


Apêndice A (continuação)

\begin{tabular}{|c|c|c|c|c|c|c|c|c|c|c|c|c|c|c|}
\hline \multirow{2}{*}{ Cód. ${ }^{l}$} & \multirow{2}{*}{ População } & \multirow{2}{*}{ Aldeia - País } & \multirow{2}{*}{$n^{2}$} & \multicolumn{6}{|c|}{ Haplogrupos } & \multirow{2}{*}{$\begin{array}{l}\text { Longi- } \\
\text { tude }^{4}\end{array}$} & \multirow{2}{*}{$\begin{array}{l}\text { Lati- } \\
\text { tude }\end{array}$} & \multirow{2}{*}{$\begin{array}{l}\text { Afiliação } \\
\text { lingüistica }^{5}\end{array}$} & \multirow{2}{*}{$\begin{array}{l}\text { Área } \\
\text { geográfica }\end{array}$} & \multirow{2}{*}{ Ref. ${ }^{7}$} \\
\hline & & & & $A$ & $B$ & $C$ & $D$ & $X$ & $?^{3}$ & & & & & \\
\hline S017 & Ijka-Arhuaco & Colômbia & 40 & 33 & 0 & 7 & 0 & 0 & 0 & 73,12 & $10,28 \mathrm{~N}$ & $\mathrm{Am}, \mathrm{CP}, \mathrm{Ch}$ & AmS,And & 40 \\
\hline S018 & Kogui & Colômbia & 30 & 11 & 0 & 19 & 0 & 0 & 0 & 73,20 & $11,11 \mathrm{~N}$ & $\mathrm{Am}, \mathrm{CP}, \mathrm{Ch}$ & AmS, And & 40 \\
\hline S019 & Kuna (1) & Panamá & 16 & 16 & 0 & 0 & 0 & 0 & 0 & 77,46 & $08,21 \mathrm{~N}$ & $\mathrm{Am}, \mathrm{CP}, \mathrm{Ch}$ & AmC,Sul & 88 \\
\hline S020 & Kuna (2) & Panamá & 63 & 45 & 18 & 0 & 0 & 0 & 0 & 79,10 & $09,21 \mathrm{~N}$ & $\mathrm{Am}, \mathrm{CP}, \mathrm{Ch}$ & AmC,Sul & 5,44 \\
\hline S021 & Ngöbé & $\begin{array}{l}\text { Bocas del Toro, Rio } \\
\text { Cricamola, Soloy, Hato } \\
\text { Chamí e Tolé - Panamá }\end{array}$ & 46 & 31 & 15 & 0 & 0 & 0 & 0 & 82,10 & $08,54 \mathrm{~N}$ & $\mathrm{Am}, \mathrm{CP}, \mathrm{Ch}$ & AmC,Sul & 41 \\
\hline S022 & Teribe & Panamá & 20 & 16 & 4 & 0 & 0 & 0 & 0 & 82,33 & $09,20 \mathrm{~N}$ & $\mathrm{Am}, \mathrm{CP}, \mathrm{Ch}$ & AmC,Sul & 90 \\
\hline S023 & Tule-Cuna & Colômbia & 30 & 15 & 8 & 6 & 0 & 0 & 1 & 76,49 & $07,30 \mathrm{~N}$ & $\mathrm{Am}, \mathrm{CP}, \mathrm{Ch}$ & AmC,Sul & 40 \\
\hline S024 & Wiwa & Colômbia & 8 & 2 & 0 & 6 & 0 & 0 & 0 & 74,25 & $10,38 \mathrm{~N}$ & $\mathrm{Am}, \mathrm{CP}, \mathrm{Ch}$ & AmS,And & 40 \\
\hline S025 & Zenu & Colômbia & 34 & 5 & 11 & 17 & 1 & 0 & 0 & 75,04 & $09,01 \mathrm{~N}$ & $\mathrm{Am}, \mathrm{CP}, \mathrm{Ch}$ & AmS,And & 40 \\
\hline S026 & Zenu & $\begin{array}{l}\text { San Andrés de Sotavento - } \\
\text { Colômbia }\end{array}$ & 37 & 7 & 15 & 11 & 2 & 0 & 2 & 75,40 & $08,21 \mathrm{~N}$ & $\mathrm{Am}, \mathrm{CP}, \mathrm{Ch}$ & AmS,And & 59 \\
\hline S027 & Atacameno (1) & $\begin{array}{l}\text { San Pedro de Atacama - } \\
\text { Chile }\end{array}$ & 13 & 3 & 9 & 1 & 0 & 0 & 0 & 68,37 & $22,00 \mathrm{~S}$ & $\mathrm{Am}, \mathrm{CP}, \mathrm{Pa}$ & AmS,And & 4 \\
\hline S028 & Atacameno (2) & $\begin{array}{l}\text { San Pedro de Atacama - } \\
\text { Chile }\end{array}$ & 50 & 6 & 36 & 5 & 3 & 0 & 0 & 68,00 & $23,05 \mathrm{~S}$ & $\mathrm{Am}, \mathrm{CP}, \mathrm{Pa}$ & AmS,And & 54 \\
\hline S029 & Atacameno (3) & $\begin{array}{l}\text { San Pedro de Atacama - } \\
\text { Chile }\end{array}$ & 23 & 2 & 14 & 6 & 1 & 0 & 0 & 68,00 & $22,00 \mathrm{~S}$ & $\mathrm{Am}, \mathrm{CP}, \mathrm{Pa}$ & AmS,And & 71 \\
\hline S030 & Guambiano & Colômbia & 23 & 1 & 1 & 18 & 3 & 0 & 0 & 76,30 & $02,04 \mathrm{~N}$ & $\mathrm{Am}, \mathrm{CP}, \mathrm{Pa}$ & AmS,And & 40 \\
\hline S031 & Paez & Colômbia & 31 & 18 & 2 & 11 & 0 & 0 & 0 & 75,49 & $02,27 \mathrm{~N}$ & $\mathrm{Am}, \mathrm{CP}, \mathrm{Pa}$ & AmS,And & 40 \\
\hline S032 & Pasto & Colômbia & 9 & 6 & 3 & 0 & 0 & 0 & 0 & 77,34 & $00,52 \mathrm{~N}$ & $\mathrm{Am}, \mathrm{CP}, \mathrm{Pa}$ & AmS,And & 40 \\
\hline S033 & Cayapa & Equador & 120 & 35 & 48 & 11 & 0 & 0 & 26 & 78,50 & $01,17 \mathrm{~N}$ & $\mathrm{Am}, \mathrm{CP}, \mathrm{Pa}$ & AmS,Ama & 70 \\
\hline S034 & Embera & Colômbia & 21 & 7 & 10 & 1 & 2 & 0 & 1 & 76,32 & $05,09 \mathrm{~N}$ & $\mathrm{Am}, \mathrm{CP}, \mathrm{Pa}$ & AmS,And & 40 \\
\hline S035 & Embera & Dabeiba - Colômbia & 22 & 16 & 5 & 0 & 0 & 0 & 1 & 76,16 & $07,00 \mathrm{~N}$ & $\mathrm{Am}, \mathrm{CP}, \mathrm{Pa}$ & AmS,And & 59 \\
\hline S036 & Embera & Panamá & 44 & 10 & 23 & 11 & 0 & 0 & 0 & 77,29 & $08,20 \mathrm{~N}$ & $\mathrm{Am}, \mathrm{CP}, \mathrm{Pa}$ & AmC,Sul & 42 \\
\hline S037 & Waunana & Colômbia & 30 & 0 & 19 & 9 & 2 & 0 & 0 & 76,37 & $04,41 \mathrm{~N}$ & $\mathrm{Am}, \mathrm{CP}, \mathrm{Pa}$ & AmS,And & 40 \\
\hline S038 & Wounan & Panamá & 31 & 9 & 6 & 15 & 1 & 0 & 0 & 78,15 & $08,36 \mathrm{~N}$ & $\mathrm{Am}, \mathrm{CP}, \mathrm{Pa}$ & AmC,Sul & 42 \\
\hline S039 & Ache & $\begin{array}{l}\text { Arroyo Bandera e Chupa- } \\
\text { Pou - Paraguai }\end{array}$ & 64 & 6 & 58 & 0 & 0 & 0 & 0 & 55,50 & $23,30 \mathrm{~S}$ & $\mathrm{Am}, \mathrm{ET}, \mathrm{Eq}$ & $\mathrm{AmS}, \mathrm{GrC}$ & 79 \\
\hline S040 & Assurini & Kuatinemo - Brasil & 14 & 2 & 3 & 4 & 5 & 0 & 0 & 52,37 & $05,26 \mathrm{~S}$ & $\mathrm{Am}, \mathrm{ET}, \mathrm{Eq}$ & AmS,Ama & 78 \\
\hline S041 & Assurini & Trocará - Brasil & 10 & 0 & 10 & 0 & 0 & 0 & 0 & 49,46 & $03,03 \mathrm{~S}$ & Am,ET,Eq & AmS,Ama & 78 \\
\hline S042 & Gavião & Brasil & 27 & 4 & 4 & 0 & 19 & 0 & 0 & 61,08 & $10,10 \mathrm{~S}$ & Am,ET,Eq & AmS,Ama & 44,94 \\
\hline S043 & Parakanã & Bom Jardim - Brasil & 12 & 1 & 3 & 5 & 3 & 0 & 0 & 52,07 & $06,21 \mathrm{~S}$ & Am,ET,Eq & AmS,Ama & 78 \\
\hline
\end{tabular}


Apêndice A (continuação)

\begin{tabular}{|c|c|c|c|c|c|c|c|c|c|c|c|c|c|c|}
\hline \multirow{2}{*}{ Cód. ${ }^{l}$} & \multirow{2}{*}{ População } & \multirow{2}{*}{ Aldeia - País } & \multirow{2}{*}{$n^{2}$} & \multicolumn{6}{|c|}{ Haplogrupos } & \multirow{2}{*}{$\begin{array}{l}\text { Longi- } \\
\text { tude }^{4}\end{array}$} & \multirow{2}{*}{$\begin{array}{l}\text { Lati- } \\
\text { tude }\end{array}$} & \multirow{2}{*}{$\begin{array}{l}\text { Afiliação } \\
\text { lingüistica }^{5}\end{array}$} & \multirow{2}{*}{$\begin{array}{l}\text { Área } \\
\text { geográfica }\end{array}$} & \multirow{2}{*}{ Ref. $^{7}$} \\
\hline & & & & $A$ & $B$ & $C$ & $D$ & $X$ & $?^{3}$ & & & & & \\
\hline S044 & Waiãpi & $\begin{array}{l}\text { Mariry, Araça, Ituaçu e } \\
\text { Aramirã - Brasil }\end{array}$ & 21 & 17 & 0 & 0 & 4 & 0 & 0 & 52,36 & $01,09 \mathrm{~N}$ & Am,ET,Eq & AmS,Ama & 78 \\
\hline S045 & Zoro & Brasil & 30 & 6 & 2 & 4 & 18 & 0 & 0 & 60,20 & $10,20 \mathrm{~S}$ & $\mathrm{Am}, \mathrm{ET}, \mathrm{Eq}$ & AmS,Ama & 44,94 \\
\hline S046 & $\begin{array}{l}\text { Ameríndios } \\
\text { (descendentes dos } \\
\text { Caquetío) }\end{array}$ & Oranjestad - Aruba & 16 & 1 & 1 & 2 & 9 & 0 & 3 & 69,58 & $12,30 \mathrm{~N}$ & $\mathrm{Am}, \mathrm{ET}, \mathrm{Eq}$ & AmC,Car & 86 \\
\hline S047 & Baníwa & Jandu Cachoeira - Brasil & 23 & 12 & 7 & 4 & 0 & 0 & 0 & 68,44 & $01,33 \mathrm{~N}$ & $\mathrm{Am}, \mathrm{ET}, \mathrm{Eq}$ & AmS,Ama & 1 \\
\hline S048 & Curripaco & Colômbia & 17 & 9 & 8 & 0 & 0 & 0 & 0 & 68,48 & $02,04 \mathrm{~N}$ & $\mathrm{Am}, \mathrm{ET}, \mathrm{Eq}$ & AmS,Ama & 40 \\
\hline S049 & Guahibo & $\begin{array}{l}\text { La Reforma, Pintado, } \\
\text { Porvenir e Mirabal - } \\
\text { Venezuela }\end{array}$ & 59 & 28 & 2 & 29 & 0 & 0 & 0 & 67,00 & $05,00 \mathrm{~N}$ & $\mathrm{Am}, \mathrm{ET}, \mathrm{Eq}$ & AmS,Ama & 91 \\
\hline S050 & Guahibo-Sikuani & Colômbia & 31 & 19 & 1 & 3 & 0 & 0 & 8 & 71,09 & $05,06 \mathrm{~N}$ & $\mathrm{Am}, \mathrm{ET}, \mathrm{Eq}$ & AmS,Ama & 40 \\
\hline S051 & Guayabero-Cunimia & Colômbia & 30 & 15 & 5 & 4 & 0 & 0 & 6 & 71,48 & $03,46 \mathrm{~N}$ & $\mathrm{Am}, \mathrm{ET}, \mathrm{Eq}$ & AmS,Ama & 40 \\
\hline S052 & Ignaciano & Bolívia & 22 & 4 & 8 & 9 & 0 & 0 & 1 & 65,15 & $15,41 \mathrm{~S}$ & $\mathrm{Am}, \mathrm{ET}, \mathrm{Eq}$ & AmS,Ama & 7 \\
\hline S053 & Tainos & $\begin{array}{l}\text { Ancient - República } \\
\text { Dominicana }\end{array}$ & 24 & 0 & 0 & 18 & 6 & 0 & 0 & 70,38 & $18,30 \mathrm{~N}$ & $\mathrm{Am}, \mathrm{ET}, \mathrm{Eq}$ & AmC,Car & 44 \\
\hline S054 & Trinitario & Bolívia & 35 & 5 & 14 & 13 & 1 & 0 & 2 & 65,00 & $15,41 \mathrm{~S}$ & $\mathrm{Am}, \mathrm{ET}, \mathrm{Eq}$ & AmS,Ama & 7 \\
\hline S055 & Wapishana & Brasil & 12 & 0 & 3 & 1 & 8 & 0 & 0 & 55,04 & $00,52 \mathrm{~S}$ & $\mathrm{Am}, \mathrm{ET}, \mathrm{Eq}$ & AmS,Ama & 88 \\
\hline S056 & Wayuu & Colômbia & 20 & 5 & 3 & 12 & 0 & 0 & 0 & 71,46 & $12,04 \mathrm{~N}$ & $\mathrm{Am}, \mathrm{ET}, \mathrm{Eq}$ & AmS,And & 40 \\
\hline S057 & Wayuu & $\begin{array}{l}\text { Guareripa, La Loma e } \\
\text { Ankalabary - Colômbia }\end{array}$ & 40 & 10 & 14 & 15 & 0 & 0 & 1 & 72,08 & $11,48 \mathrm{~N}$ & $\mathrm{Am}, \mathrm{ET}, \mathrm{Eq}$ & AmS, And & 59 \\
\hline S058 & Yamamadi & Brasil & 10 & 0 & 0 & 10 & 0 & 0 & 0 & 66,41 & $07,15 \mathrm{~S}$ & $\mathrm{Am}, \mathrm{ET}, \mathrm{Eq}$ & AmS,Ama & 78 \\
\hline S059 & Piaroa & Colômbia & 10 & 5 & 0 & 1 & 4 & 0 & 0 & 69,17 & $03,33 \mathrm{~N}$ & $\mathrm{Am}, \mathrm{ET}, \mathrm{Eq}$ & AmS,Ama & 88 \\
\hline S060 & Piaroa-Whothuha & Colômbia & 18 & 5 & 3 & 5 & 5 & 0 & 0 & 68,28 & $04,39 \mathrm{~N}$ & $\mathrm{Am}, \mathrm{ET}, \mathrm{Eq}$ & AmS,Ama & 40 \\
\hline S061 & Awá-Guajá & Turiaçu - Brasil & 20 & 0 & 20 & 0 & 0 & 0 & 0 & 46,18 & $02,18 \mathrm{~S}$ & $\mathrm{Am}, \mathrm{ET}, \mathrm{Eq}$ & AmS,Ama & 78 \\
\hline S062 & Poturujara (Zoé) & Cuminapanema - Brasil & 20 & 9 & 0 & 5 & 6 & 0 & 0 & 56,00 & $01,00 \mathrm{~S}$ & $\mathrm{Am}, \mathrm{ET}, \mathrm{Eq}$ & AmS,Ama & 78 \\
\hline S063 & Kanamarí & Três Unidos - Brasil & 21 & 7 & 5 & 6 & 3 & 0 & 0 & 69,32 & $06,37 \mathrm{~S}$ & Am,ET,MT & AmS,Ama & 1 \\
\hline S064 & Nukak-Maku & Colômbia & 20 & 0 & 4 & 16 & 0 & 0 & 0 & 71,17 & $03,13 \mathrm{~N}$ & $\mathrm{Am}, \mathrm{ET}, \mathrm{MT}$ & AmS,Ama & 40 \\
\hline S065 & Tikúna & Arara e Cotuhé - Colômbia & 54 & 7 & 8 & 21 & 18 & 0 & 0 & 70,04 & $03,19 \mathrm{~S}$ & Am,ET,MT & AmS,Ama & 59 \\
\hline S066 & Tikúna & Brasil & 28 & 5 & 0 & 9 & 14 & 0 & 0 & 64,13 & $05,58 \mathrm{~S}$ & $\mathrm{Am}, \mathrm{ET}, \mathrm{MT}$ & AmS,Ama & 80,87 \\
\hline S067 & Tikúna & Belém - Brasil & 26 & 5 & 0 & 5 & 16 & 0 & 0 & 69,37 & $03,55 \mathrm{~S}$ & Am,ET,MT & AmS,Ama & 1 \\
\hline S068 & Tikúna & Bom Jardim - Brasil & 18 & 3 & 2 & 10 & 3 & 0 & 0 & 70,03 & $04,25 \mathrm{~S}$ & Am,ET,MT & AmS,Ama & 1 \\
\hline S069 & Tikúna & Campo Alegre - Brasil & 23 & 5 & 1 & 9 & 8 & 0 & 0 & 69,27 & $03,25 \mathrm{~S}$ & Am,ET,MT & AmS,Ama & 1 \\
\hline S070 & Tikúna & Feijoal - Brasil & 25 & 12 & 2 & 9 & 2 & 0 & 0 & 69,35 & $04,15 \mathrm{~S}$ & Am,ET,MT & AmS,Ama & 1 \\
\hline S071 & Tikúna & Marajá - Brasil & 22 & 7 & 3 & 6 & 6 & 0 & 0 & 69,42 & $04,20 \mathrm{~S}$ & Am,ET,MT & AmS,Ama & 1 \\
\hline
\end{tabular}




\section{Apêndice A (continuação)}

\begin{tabular}{|c|c|c|c|c|c|c|c|c|c|c|c|c|c|c|}
\hline \multirow{2}{*}{ Cód. ${ }^{l}$} & \multirow{2}{*}{ População } & \multirow{2}{*}{ Aldeia - País } & \multirow{2}{*}{$n^{2}$} & \multicolumn{6}{|c|}{ Haplogrupos } & \multirow{2}{*}{$\begin{array}{l}\text { Longi- } \\
\text { tude }\end{array}$} & \multirow{2}{*}{$\begin{array}{l}\text { Lati- } \\
\text { tude }\end{array}$} & \multirow{2}{*}{$\begin{array}{l}\text { Afiliação } \\
\text { lingüistica }\end{array}$} & \multirow{2}{*}{$\begin{array}{l}\text { Área } \\
\text { geográfica }\end{array}$} & \multirow{2}{*}{ Ref. ${ }^{7}$} \\
\hline & & & & $A$ & $B$ & $C$ & $D$ & $X$ & $?^{3}$ & & & & & \\
\hline S072 & Tikúna & Nova Itália - Brasil & 26 & 5 & 3 & 9 & 9 & 0 & 0 & 68,07 & $03,37 \mathrm{~S}$ & Am,ET,MT & AmS,Ama & 1 \\
\hline S073 & Tikúna & Umariaçu - Brasil & 24 & 4 & 0 & 11 & 9 & 0 & 0 & 69,55 & $04,17 \mathrm{~S}$ & Am,ET,MT & AmS,Ama & 1 \\
\hline S074 & Tikúna & Vendaval - Brasil & 23 & 5 & 0 & 5 & 13 & 0 & 0 & 69,27 & $03,30 \mathrm{~S}$ & Am,ET,MT & AmS,Ama & 1 \\
\hline S075 & Siona & Colômbia & 12 & 9 & 2 & 1 & 0 & 0 & 0 & 75,47 & $00,18 \mathrm{~N}$ & Am,ET,MT & AmS,Ama & 40 \\
\hline S076 & Coreguaje & Colômbia & 42 & 2 & 9 & 27 & 1 & 0 & 3 & 75,41 & $00,54 \mathrm{~N}$ & Am,ET,MT & AmS,Ama & 40 \\
\hline S077 & Tucano & Colômbia & 17 & 0 & 3 & 8 & 6 & 0 & 0 & 69,57 & $00,54 \mathrm{~N}$ & Am,ET,MT & AmS,Ama & 40 \\
\hline S078 & Movima & Bolívia & 22 & 2 & 2 & 14 & 4 & 0 & 0 & 65,41 & $14,16 \mathrm{~S}$ & Am,ET,MT & AmS,Ama & 7 \\
\hline S079 & Yuracaré & Bolívia & 28 & 11 & 9 & 6 & 1 & 0 & 1 & 66,30 & $16,03 \mathrm{~S}$ & Am,ET,-- & AmS,And & 7 \\
\hline S080 & Arara & Iriri - Brasil & 10 & 10 & 0 & 0 & 0 & 0 & 0 & 52,47 & $03,51 \mathrm{~S}$ & Am,GPC,MC & AmS,Ama & 78 \\
\hline S081 & Arara & Laranjal - Brasil & 12 & 0 & 3 & 9 & 0 & 0 & 0 & 52,47 & $03,51 \mathrm{~S}$ & $\mathrm{Am}, \mathrm{GPC}, \mathrm{MC}$ & AmS,Ama & 78 \\
\hline S082 & Katuena & Mapuera - Brasil & 20 & 5 & 1 & 8 & 6 & 0 & 0 & 58,00 & $00,43 \mathrm{~S}$ & $\mathrm{Am}, \mathrm{GPC}, \mathrm{MC}$ & AmS,Ama & 78 \\
\hline S083 & Macushi & Brasil & 10 & 1 & 2 & 3 & 4 & 0 & 0 & 58,18 & $00,54 \mathrm{~N}$ & Am,GPC,MC & AmS,Ama & 88 \\
\hline S084 & Makiritare & Venezuela & 10 & 2 & 0 & 7 & 1 & 0 & 0 & 64,40 & $01,30 \mathrm{~N}$ & Am, GPC,MC & AmS,Ama & 88 \\
\hline S085 & Tiryó & Sede - Brasil & 2 & 0 & 0 & 0 & 2 & 0 & 0 & & & & & 78 \\
\hline S086 & Yuko-Yukpa & Colômbia & 88 & 0 & 88 & 0 & 0 & 0 & 0 & 73,06 & $08,59 \mathrm{~N}$ & $\mathrm{Am}, \mathrm{GPC}, \mathrm{MC}$ & AmS,And & 40 \\
\hline S087 & Huitoto & Colômbia & 22 & 6 & 1 & 5 & 10 & 0 & 0 & 74,36 & $00,09 \mathrm{~N}$ & $\mathrm{Am}, \mathrm{GPC}, \mathrm{MC}$ & AmS,Ama & 40 \\
\hline S088 & Murui-Muinane & Colômbia & 19 & 2 & 4 & 7 & 5 & 0 & 1 & 74,07 & $00,42 \mathrm{~N}$ & Am,GPC,MC & AmS,Ama & 40 \\
\hline S089 & Kayapó & $\begin{array}{l}\text { Kokraimoro, Kubenkokre } \\
\text { e Kikretun - Brasil }\end{array}$ & 13 & 6 & 7 & 0 & 0 & 0 & 0 & 53,00 & $07,00 \mathrm{~S}$ & $\mathrm{Am}, \mathrm{GPC}, \mathrm{MG}$ & AmS,Ama & 78 \\
\hline S090 & Kraho & Brasil & 14 & 4 & 8 & 2 & 0 & 0 & 0 & 49,33 & $15,51 \mathrm{~S}$ & Am,GPC,MG & AmS,Ama & 88 \\
\hline S091 & Xavante & Brasil & 25 & 4 & 21 & 0 & 0 & 0 & 0 & 51,40 & $13,20 \mathrm{~S}$ & $\mathrm{Am}, \mathrm{GPC}, \mathrm{MG}$ & AmS,Ama & 44,94 \\
\hline S092 & Choroti & $\begin{array}{l}\text { La Merced, La Gracia, La } \\
\text { Esperanza e La Curvita - } \\
\text { Argentina }\end{array}$ & 6 & 1 & 1 & 4 & 0 & 0 & 0 & 63,42 & $22,17 \mathrm{~S}$ & Am,GPC,MP & $\mathrm{AmS}, \mathrm{GrC}$ & 33 \\
\hline S093 & Choroti & $\begin{array}{l}\text { Santa Victoria Este - } \\
\text { Argentina }\end{array}$ & 14 & 2 & 7 & 2 & 3 & 0 & 0 & 62,46 & $22,16 \mathrm{~S}$ & Am,GPC,MP & $\mathrm{AmS}, \mathrm{GrC}$ & 8 \\
\hline S094 & Mataco (Wichí) & El Potrillo - Argentina & 44 & 4 & 24 & 9 & 7 & 0 & 0 & 62,29 & $23,40 \mathrm{~S}$ & Am,GPC,MP & $\mathrm{AmS}, \mathrm{GrC}$ & 23 \\
\hline S095 & Mataco (Wichí) & El Sauzalito - Argentina & 28 & 3 & 10 & 0 & 15 & 0 & 0 & 60,28 & $25,23 \mathrm{~S}$ & Am,GPC,MP & $\mathrm{AmS}, \mathrm{GrC}$ & 88 \\
\hline S096 & Mataco (Wichí) & $\begin{array}{l}\text { La Paz, Las Vertientes, } \\
\text { Pozo del Tigre, San Luíz e } \\
\text { La Curvita - Argentina }\end{array}$ & 15 & 0 & 9 & 0 & 6 & 0 & 0 & 63,42 & $22,17 \mathrm{~S}$ & Am,GPC,MP & $\mathrm{AmS}, \mathrm{GrC}$ & 33 \\
\hline S097 & Mataco (Wichí) & $\begin{array}{l}\text { Santa Victoria Este - } \\
\text { Argentina }\end{array}$ & 57 & 4 & 36 & 2 & 13 & 0 & 2 & 62,45 & $22,13 \mathrm{~S}$ & Am,GPC,MP & $\mathrm{AmS}, \mathrm{GrC}$ & 8 \\
\hline S098 & Pilagá & San Martín II - Argentina & 41 & 2 & 15 & 11 & 12 & 0 & 1 & 59,10 & $24,39 \mathrm{~S}$ & Am,GPC,MP & $\mathrm{AmS}, \mathrm{GrC}$ & 23 \\
\hline S099 & Toba & Castelli - Argentina & 30 & 4 & 14 & 2 & 8 & 0 & 2 & 60,35 & $26,38 \mathrm{~S}$ & Am,GPC,MP & $\mathrm{AmS}, \mathrm{GrC}$ & 23 \\
\hline
\end{tabular}


Apêndice A (continuação)

\begin{tabular}{|c|c|c|c|c|c|c|c|c|c|c|c|c|c|c|}
\hline \multirow{2}{*}{ Cód. ${ }^{l}$} & \multirow{2}{*}{ População } & \multirow{2}{*}{ Aldeia-País } & \multirow{2}{*}{$n^{2}$} & \multicolumn{6}{|c|}{ Haplogrupos } & \multirow{2}{*}{$\begin{array}{l}\text { Longi- } \\
\text { tude }\end{array}$} & \multirow{2}{*}{$\begin{array}{l}\text { Lati- } \\
\text { tude }\end{array}$} & \multirow{2}{*}{$\begin{array}{l}\text { Afiliação } \\
\text { lingüística } 5\end{array}$} & \multirow{2}{*}{$\begin{array}{l}\text { Area } \\
\text { geográfica }\end{array}$} & \multirow{2}{*}{ Ref. $^{7}$} \\
\hline & & & & $A$ & $B$ & $C$ & $D$ & $X$ & $?^{3}$ & & & & & \\
\hline S100 & Toba & $\begin{array}{l}\text { Monte Carmelo e La } \\
\text { Curvita - Argentina }\end{array}$ & 9 & 0 & 3 & 1 & 5 & 0 & 0 & 59,30 & $26,35 \mathrm{~S}$ & Am,GPC,MP & AmS,GrC & 8,33 \\
\hline S101 & Toba & Nanqon - Argentina & 26 & 7 & 9 & 1 & 9 & 0 & 0 & 58,21 & $26,32 \mathrm{~S}$ & Am,GPC,MP & $\mathrm{AmS}, \mathrm{GrC}$ & 23 \\
\hline S102 & Katukina & Morada Nova - Brasil & 11 & 1 & 0 & 5 & 4 & 0 & 1 & 70,21 & $08,09 \mathrm{~S}$ & Am,GPC,MP & AmS,Ama & 1 \\
\hline S103 & Katukina & Sete Estrelas - Brasil & 14 & 11 & 3 & 0 & 0 & 0 & 0 & 71,34 & $08,17 \mathrm{~S}$ & Am,GPC,MP & AmS,Ama & 1 \\
\hline S104 & Kaxináwa & Canabrava - Brasil & 12 & 4 & 1 & 6 & 1 & 0 & 0 & 70,19 & $08,07 \mathrm{~S}$ & Am,GPC,MP & AmS,Ama & 1 \\
\hline S105 & Kaxináwa & Paredão - Brasil & 7 & 4 & 0 & 3 & 0 & 0 & 0 & 70,19 & $08,07 \mathrm{~S}$ & Am,GPC,MP & AmS,Ama & 1 \\
\hline S106 & Marúbo & Vida Nova - Brasil & 18 & 0 & 3 & 9 & 6 & 0 & 0 & 72,08 & $06,47 \mathrm{~S}$ & Am,GPC,MP & AmS,Ama & 1 \\
\hline S107 & Marúbo & Brasil & 10 & 1 & 0 & 6 & 3 & 0 & 0 & 69,17 & $08,24 \mathrm{~S}$ & Am,GPC,MP & AmS,Ama & 88 \\
\hline S108 & Yaminawa & Brasil & 15 & 9 & 0 & 5 & 1 & 0 & 0 & 71,34 & $08,17 \mathrm{~S}$ & Am,GPC,MP & AmS,Ama & 1 \\
\hline S109 & Chimane & Bolívia & 41 & 16 & 22 & 2 & 0 & 0 & 1 & 67,19 & $14,24 \mathrm{~S}$ & Am,GPC,-- & AmS,And & 7 \\
\hline $\mathrm{S} 110$ & Mosetén & Bolívia & 20 & 8 & 11 & 0 & 0 & 0 & 1 & 66,43 & $14,24 \mathrm{~S}$ & Am,GPC,-- & AmS,And & 7 \\
\hline S111 & Aymara & Bolívia & 33 & 0 & 31 & 1 & 1 & 0 & 0 & 68,58 & $17,10 \mathrm{~S}$ & Am,An,Ay & AmS,And & 7 \\
\hline S112 & Aymara & Arica - Chile & 120 & 9 & 68 & 22 & 19 & 0 & 2 & 70,18 & $18,28 \mathrm{~S}$ & Am,An,Ay & AmS,And & 64,71 \\
\hline S113 & Aymara & Caquena - Chile & 23 & 4 & 14 & 3 & 2 & 0 & 0 & 69,15 & $18,17 \mathrm{~S}$ & Am,An,Ay & AmS,And & 54 \\
\hline S114 & Aymara & Codpa - Chile & 9 & 1 & 6 & 1 & 1 & 0 & 0 & 69,51 & $19,22 \mathrm{~S}$ & Am,An,Ay & AmS,And & 54 \\
\hline S115 & Aymara & Esquina - Chile & 14 & 0 & 9 & 0 & 5 & 0 & 0 & 68,90 & $17,22 \mathrm{~S}$ & Am,An,Ay & AmS,And & 54 \\
\hline S116 & Aymara & Guallatiri - Chile & 9 & 0 & 5 & 3 & 1 & 0 & 0 & 69,18 & $19,03 \mathrm{~S}$ & Am,An,Ay & AmS,And & 54 \\
\hline S117 & Aymara & Guanacagua - Chile & 17 & 0 & 17 & 0 & 0 & 0 & 0 & 68,90 & $17,22 \mathrm{~S}$ & Am,An,Ay & AmS,And & 54 \\
\hline S118 & Aymara & Illapata - Chile & 12 & 0 & 12 & 0 & 0 & 0 & 0 & 68,90 & $17,22 \mathrm{~S}$ & Am,An,Ay & AmS,And & 54 \\
\hline S119 & Aymara & Parinacota - Chile & 12 & 1 & 6 & 5 & 0 & 0 & 0 & 69,25 & $18,32 \mathrm{~S}$ & Am,An,Ay & AmS,And & 54 \\
\hline S120 & Aymara & Visviri - Chile & 76 & 5 & 49 & 8 & 14 & 0 & 0 & 69,30 & $17,39 \mathrm{~S}$ & Am,An,Ay & AmS,And & 54 \\
\hline S121 & Ingano & Colômbia & 21 & 8 & 2 & 11 & 0 & 0 & 0 & 76,32 & $01,08 \mathrm{~N}$ & $\mathrm{Am}, \mathrm{An}, \mathrm{Qu}$ & AmS,And & 40 \\
\hline S122 & Ingano & $\begin{array}{l}\text { San Miguel e Sibundoy - } \\
\text { Colômbia }\end{array}$ & 27 & 4 & 12 & 10 & 0 & 0 & 1 & 76,12 & $00,57 \mathrm{~N}$ & $\mathrm{Am}, \mathrm{An}, \mathrm{Qu}$ & AmS,And & 59 \\
\hline S123 & Quechua & Bolívia & 32 & 5 & 24 & 3 & 0 & 0 & 0 & 67,14 & $21,16 \mathrm{~S}$ & $\mathrm{Am}, \mathrm{An}, \mathrm{Qu}$ & AmS,And & 7 \\
\hline S124 & Quechua & Arequipa - Peru & 22 & 2 & 15 & 3 & 2 & 0 & 0 & 71,03 & $14,31 \mathrm{~S}$ & $\mathrm{Am}, \mathrm{An}, \mathrm{Qu}$ & AmS,And & 29 \\
\hline $\mathrm{S} 125$ & Quechua & $\begin{array}{l}\text { Cabana, Chacas e } \\
\text { Independencia - Peru }\end{array}$ & 33 & 3 & 17 & 6 & 7 & 0 & 0 & 78,10 & $09,10 \mathrm{~S}$ & $\mathrm{Am}, \mathrm{An}, \mathrm{Qu}$ & AmS,And & 46 \\
\hline S126 & Quechua & Pasco - Peru & 52 & 2 & 28 & 9 & 10 & 0 & 3 & 77,03 & $12,01 \mathrm{~S}$ & $\mathrm{Am}, \mathrm{An}, \mathrm{Qu}$ & AmS,And & 73 \\
\hline S127 & Quechua & Peru & 19 & 5 & 7 & 1 & 6 & 0 & 0 & 71,34 & $11,38 \mathrm{~S}$ & $\mathrm{Am}, \mathrm{An}, \mathrm{Qu}$ & AmS,And & 54 \\
\hline S128 & Quechua & Tayacaja - Peru & 61 & 13 & 20 & 8 & 20 & 0 & 0 & 72,19 & $12,30 \mathrm{~S}$ & $\mathrm{Am}, \mathrm{An}, \mathrm{Qu}$ & AmS,And & 29 \\
\hline S129 & $\begin{array}{l}\text { Quechua/ } \\
\text { Nmatsiguenga }\end{array}$ & $\begin{array}{l}\text { San Martin de Pangoa - } \\
\text { Peru }\end{array}$ & 22 & 2 & 12 & 1 & 7 & 0 & 0 & 74,25 & $08,49 \mathrm{~S}$ & $\mathrm{Am}, \mathrm{An}, \mathrm{Qu}$ & AmS,And & 29 \\
\hline
\end{tabular}


Apêndice A (continuação)

\begin{tabular}{|c|c|c|c|c|c|c|c|c|c|c|c|c|c|c|}
\hline \multirow{2}{*}{ Cód. ${ }^{l}$} & \multirow{2}{*}{ População } & \multirow{2}{*}{ Aldeia - País } & \multirow{2}{*}{$n^{2}$} & \multicolumn{6}{|c|}{ Haplogrupos } & \multirow{2}{*}{$\begin{array}{l}\text { Longi- } \\
\text { tude }^{4}\end{array}$} & \multirow{2}{*}{$\begin{array}{l}\text { Lati- } \\
\text { tude }\end{array}$} & \multirow{2}{*}{$\begin{array}{l}\text { Afiliação } \\
\text { lingüistica }^{5}\end{array}$} & \multirow{2}{*}{$\begin{array}{l}\text { Área } \\
\text { geográfica }\end{array}$} & \multirow{2}{*}{ Ref. ${ }^{7}$} \\
\hline & & & & $A$ & $B$ & $C$ & $D$ & $X$ & $?^{3}$ & & & & & \\
\hline $\mathrm{S} 130$ & $\begin{array}{l}\text { Ameríndios } \\
\text { (descendentes dos } \\
\text { Huilliche) }\end{array}$ & Caremalpu - Chile & 47 & 2 & 14 & 18 & 12 & 0 & 1 & 73,44 & $41,45 \mathrm{~S}$ & Am,An,So & AmS,And & 30 \\
\hline S131 & $\begin{array}{l}\text { Ameríndios } \\
\text { (descendentes dos } \\
\text { Huilliche) }\end{array}$ & Detif - Chile & 27 & 3 & 6 & 10 & 8 & 0 & 0 & 73,38 & $42,40 \mathrm{~S}$ & Am,An,So & AmS,And & 30 \\
\hline S132 & $\begin{array}{l}\text { Ameríndios } \\
\text { (descendentes dos } \\
\text { Huilliche) }\end{array}$ & Quetalmahue - Chile & 42 & 0 & 13 & 15 & 11 & 0 & 3 & 73,55 & $41,50 \mathrm{~S}$ & Am,An,So & AmS,And & 30 \\
\hline S133 & Huilliche & Chile & 80 & 3 & 23 & 15 & 39 & 0 & 0 & 73,35 & $40,50 \mathrm{~S}$ & Am,An,So & AmS,And & 54 \\
\hline S134 & Huilliche & $\begin{array}{l}\text { San Juan de la Costa - } \\
\text { Chile }\end{array}$ & 38 & 2 & 11 & 7 & 18 & 0 & 0 & 73,00 & $41,16 \mathrm{~S}$ & Am,An,So & AmS,And & 4 \\
\hline S135 & Mapuche & Argentina & 63 & 4 & 23 & 12 & 18 & 0 & 6 & 71,00 & $40,05 \mathrm{~S}$ & Am,An,So & AmS,And & 8 \\
\hline S136 & Mapuche & $\begin{array}{l}\text { Aguada Guzmán - } \\
\text { Argentina }\end{array}$ & 32 & 2 & 9 & 6 & 14 & 0 & 1 & 68,57 & $39,30 \mathrm{~S}$ & Am,An,So & AmS,And & 4,32 \\
\hline S137 & Mapuche & $\begin{array}{l}\text { Anecón Grande - } \\
\text { Argentina }\end{array}$ & 39 & 6 & 15 & 8 & 10 & 0 & 0 & 70,22 & $41,20 \mathrm{~S}$ & Am,An,So & AmS,And & 31,32 \\
\hline S138 & Mapuche & Cerro Polícia - Argentina & 26 & 1 & 9 & 7 & 4 & 0 & 5 & 68,37 & $39,10 \mathrm{~S}$ & Am,An,So & AmS,And & 4,32 \\
\hline S139 & Mapuche & Ilha Huapi - Chile & 111 & 0 & 8 & 49 & 54 & 0 & 0 & 72,25 & $40,15 \mathrm{~S}$ & Am,An,So & AmS,And & 63 \\
\hline S140 & Mapuche & $\begin{array}{l}\text { Laitec, Yaldad, Quellon, } \\
\text { La Mision, Los Galpones, } \\
\text { Guinimo, Paraquina, } \\
\text { Cocauque e Icalma Chile }\end{array}$ & 45 & 2 & 10 & 18 & 15 & 0 & 0 & 73,14 & $40,52 \mathrm{~S}$ & Am,An,So & AmS,And & 37,54 \\
\hline S141 & Pehuenche & Butalelbun - Chile & 26 & 0 & 1 & 7 & 18 & 0 & 0 & 71,16 & $37,43 \mathrm{~S}$ & Am,An,So & AmS,And & 54 \\
\hline $\mathrm{S} 142$ & Pehuenche (1) & Trapa Trapa - Chile & 74 & 2 & 8 & 30 & 34 & 0 & 0 & 71,16 & $37,43 \mathrm{~S}$ & Am,An,So & AmS,And & 54 \\
\hline $\mathrm{S} 143$ & Pehuenche (2) & Trapa Trapa - Chile & 105 & 3 & 11 & 43 & 48 & 0 & 0 & 71,16 & $37,43 \mathrm{~S}$ & Am,An,So & AmS,And & 63 \\
\hline S144 & $\begin{array}{l}\text { Aónikenk } \\
\text { (Tehuelche) }\end{array}$ & Ancient - Argentina & 15 & 0 & 0 & 4 & 11 & 0 & 0 & 69,00 & $52,00 \mathrm{~S}$ & Am,An,So & $\mathrm{AmS}, \mathrm{TdF}$ & 43 \\
\hline S145 & Tehuelche & $\begin{array}{l}\text { El Chalia e Loma Redonda } \\
\text { - Argentina }\end{array}$ & 29 & 0 & 6 & 7 & 16 & 0 & 0 & 71,00 & $45,00 \mathrm{~S}$ & Am,An,So & AmS,And & 63 \\
\hline S146 & Ameríndios & $\begin{array}{l}\text { Quebrada de Humahuaca - } \\
\text { Argentina }\end{array}$ & 46 & 5 & 31 & 8 & 2 & 0 & 0 & 65,18 & $24,11 \mathrm{~S}$ & $\mathrm{Am}, \mathrm{Na},-$ & AmS,And & 25 \\
\hline S147 & Ameríndios & $\begin{array}{l}\text { San Salvador de Jujuy - } \\
\text { Argentina }\end{array}$ & 19 & 3 & 11 & 3 & 2 & 0 & 0 & 65,00 & $24,00 \mathrm{~S}$ & $\mathrm{Am}, \mathrm{Na},-$ & AmS,And & 25 \\
\hline $\mathrm{S} 148$ & Fueguian & Ancient - Argentina & 2 & 0 & 0 & 0 & 2 & 0 & 0 & & & & & 97 \\
\hline
\end{tabular}




\section{Apêndice A (continuação)}

\begin{tabular}{|c|c|c|c|c|c|c|c|c|c|c|c|c|c|c|}
\hline \multirow{2}{*}{ Cód. ${ }^{l}$} & \multirow{2}{*}{ População } & \multirow{2}{*}{ Aldeia - País } & \multirow{2}{*}{$n^{2}$} & \multicolumn{6}{|c|}{ Haplogrupos } & \multirow{2}{*}{$\begin{array}{l}\text { Longi- } \\
\text { tude }\end{array}$} & \multirow{2}{*}{$\begin{array}{l}\text { Lati- } \\
\text { tude }\end{array}$} & \multirow{2}{*}{$\begin{array}{l}\text { Afiliação } \\
\text { lingüística }^{5}\end{array}$} & \multirow{2}{*}{$\begin{array}{l}\text { Área } \\
\text { geográfica }\end{array}$} & \multirow{2}{*}{$\operatorname{Ref.}^{\top}$} \\
\hline & & & & $A$ & $B$ & $C$ & $D$ & $X$ & $?^{3}$ & & & & & \\
\hline S149 & $\begin{array}{l}\text { Kawéskar } \\
\text { (Alakaluf) }\end{array}$ & Ancient - Argentina & 19 & 0 & 0 & 3 & 16 & 0 & 0 & 66,30 & $54,55 \mathrm{~S}$ & Am,An,So & $\mathrm{AmS}, \mathrm{TdF}$ & 43 \\
\hline S150 & Selk'nam (Ona) & Ancient - Argentina & 13 & 0 & 0 & 6 & 6 & 0 & 1 & 68,30 & $54,00 \mathrm{~S}$ & Am,An,So & $\mathrm{AmS}, \mathrm{TdF}$ & 43 \\
\hline S151 & Yámana (Yaghan) & Ancient - Argentina & 11 & 0 & 0 & 10 & 1 & 0 & 0 & 66,00 & $54,50 \mathrm{~S}$ & Am,An,So & $\mathrm{AmS}, \mathrm{TdF}$ & 43 \\
\hline S152 & Yámana (Yaghan) & Puerto Williams - Chile & 21 & 0 & 0 & 10 & 11 & 0 & 0 & 67,40 & $55,00 \mathrm{~S}$ & Am,An,So & $\mathrm{AmS}, \mathrm{TdF}$ & 63 \\
\hline S153 & Ameríndios & $\begin{array}{l}\text { Riohacha, Aponte, Cumbal } \\
\text { e Sibundoy - Colômbia }\end{array}$ & 20 & 10 & 4 & 5 & 1 & 0 & 0 & 75,00 & $01,30 \mathrm{~N}$ & Ameríndios & AmS,And & 37,44 \\
\hline S154 & $\begin{array}{l}\text { Ameríndios } \\
\text { (descendentes dos } \\
\text { Chango) }\end{array}$ & Caleta Paposo - Chile & 40 & 1 & 19 & 6 & 11 & 0 & 3 & 70,27 & $25,03 \mathrm{~S}$ & Ameríndios & AmS,And & 36 \\
\hline $\mathrm{S} 155$ & $\begin{array}{l}\text { Ameríndios } \\
\text { (descendentes dos } \\
\text { Chono) }\end{array}$ & Laitec-Chile & 42 & 0 & 0 & 15 & 24 & 0 & 3 & 73,38 & $43,07 \mathrm{~S}$ & Ameríndios & AmS,And & 30 \\
\hline S156 & Rural & Aicuña - Argentina & 22 & 21 & 1 & 0 & 0 & 0 & 0 & & & & & 96 \\
\hline S157 & Urbano - Clefting & $\begin{array}{l}\text { Argentina, Bolívia, Brasil, } \\
\text { Chile, Equador, Paraguai, } \\
\text { Uruguai, Venezuela }\end{array}$ & 168 & 10 & 1 & 4 & 149 & 0 & 4 & & & & & 98 \\
\hline $\mathrm{S} 158$ & Urbano - Controle & $\begin{array}{l}\text { Argentina, Bolívia, Brasil, } \\
\text { Chile, Equador, Paraguai, } \\
\text { Uruguai, Venezuela }\end{array}$ & 148 & 21 & 1 & 40 & 22 & 0 & 64 & & & & & 98 \\
\hline S159 & Urbano & Belém - Brasil & 155 & 34 & 18 & 27 & 10 & 0 & 66 & 48,30 & $01,25 \mathrm{~S}$ & Urbano & & 6 \\
\hline S160 & Urbano & Nordeste - Brasil & 50 & 4 & 3 & 1 & 3 & 0 & 39 & 35,00 & $08,05 \mathrm{~S}$ & Urbano & & 3 \\
\hline S161 & Urbano & Norte - Brasil & 48 & 4 & 8 & 10 & 4 & 0 & 22 & 60,00 & $05,00 \mathrm{~S}$ & Urbano & & 3 \\
\hline S162 & Urbano & Veranópolis - Brasil & 111 & 1 & 1 & 5 & 2 & 0 & 102 & 51,34 & $28,55 \mathrm{~S}$ & Urbano & & 52 \\
\hline S163 & Urbano & Santarém - Brasil & 159 & 45 & 39 & 25 & 11 & 0 & 39 & 54,43 & $02,25 \mathrm{~S}$ & Urbano & & 28 \\
\hline S164 & Urbano & Sudeste - Brasil & 99 & 13 & 10 & 6 & 4 & 0 & 66 & 43,56 & $19,54 \mathrm{~S}$ & Urbano & & 3 \\
\hline S165 & Urbano & Sul - Brasil & 50 & 3 & 3 & 3 & 2 & 0 & 39 & 49,00 & $27,30 \mathrm{~S}$ & Urbano & & 3 \\
\hline S166 & Urbano (1) & Santiago - Chile & 75 & 5 & 16 & 25 & 17 & 0 & 12 & 70,38 & $33,27 \mathrm{~S}$ & Urbano & & 71 \\
\hline S167 & Urbano (2) & Santiago - Chile & 87 & 6 & 23 & 27 & 17 & 0 & 14 & 70,38 & $33,27 \mathrm{~S}$ & Urbano & & 71 \\
\hline S168 & Urbano & Bogotá - Colômbia & 91 & 34 & 24 & 7 & 6 & 0 & 20 & 74,06 & $04,39 \mathrm{~N}$ & Urbano & & 72 \\
\hline S169 & Urbano & Medellin - Colômbia & 80 & 36 & 30 & 5 & 1 & 0 & 8 & 75,36 & $06,15 \mathrm{~N}$ & Urbano & & 16 \\
\hline S170 & Urbano & $\begin{array}{l}\text { Central Valley - Costa } \\
\text { Rica }\end{array}$ & 59 & 31 & 16 & 2 & 0 & 0 & 10 & 84,05 & $09,56 \mathrm{~N}$ & Urbano & & 17 \\
\hline S171 & Urbano & $\begin{array}{l}\text { Hoyo de La Cumbre - } \\
\text { Venezuela }\end{array}$ & 42 & 1 & 0 & 0 & 0 & 0 & 41 & & & & & 22 \\
\hline
\end{tabular}


Apêndice A (conclusão)

\begin{tabular}{|c|c|c|c|c|c|c|c|c|c|c|c|c|c|c|}
\hline \multirow{2}{*}{ Cód. ${ }^{l}$} & \multirow{2}{*}{ População } & \multirow{2}{*}{ Aldeia - País } & \multirow{2}{*}{$n^{2}$} & \multicolumn{6}{|c|}{ Haplogrupos } & \multirow{2}{*}{$\begin{array}{l}\text { Longi- } \\
\text { tude }^{4}\end{array}$} & \multirow{2}{*}{$\begin{array}{l}\text { Lati- } \\
\text { tude }\end{array}$} & \multirow{2}{*}{$\begin{array}{l}\text { Afiliaçãao } \\
\text { lingüistica }^{5}\end{array}$} & \multirow{2}{*}{$\begin{array}{l}\text { Área } \\
\text { geográfica }^{6}\end{array}$} & \multirow{2}{*}{ Ref. } \\
\hline & & & & $A$ & $B$ & $C$ & $D$ & $X$ & $?^{3}$ & & & & & \\
\hline S172 & Urbano & $\begin{array}{l}\text { San Antonio de Los Altos - } \\
\text { Venezuela }\end{array}$ & 58 & 4 & 1 & 2 & 2 & 0 & 49 & 66,57 & $10,24 \mathrm{~N}$ & Urbano & & 22 \\
\hline S173 & Urbano & $\begin{array}{l}\text { San Diego de Los Altos - } \\
\text { Venezuela }\end{array}$ & 24 & 7 & 1 & 1 & 0 & 0 & 15 & 66,00 & $10,20 \mathrm{~N}$ & Urbano & & 22 \\
\hline S174 & Euro-descendentes & Santa Flor - Brasil & 38 & 2 & 0 & 3 & 12 & 0 & 21 & 44,47 & $02,24 \mathrm{~S}$ & Euro-descend. & & 21 \\
\hline S175 & Euro-descendentes & Ribeirão Preto - Brasil & 70 & 1 & 0 & 5 & 2 & 0 & 62 & 47,48 & $21,09 \mathrm{~S}$ & Euro-descend. & & 2 \\
\hline S176 & Afro-descendentes & $\begin{array}{l}\text { Barra e São Gonçalo - } \\
\text { Brasil }\end{array}$ & 110 & 5 & 0 & 7 & 0 & 0 & 98 & 41,47 & $13,36 \mathrm{~S}$ & Afro-descend. & & 2 \\
\hline S177 & Afro-descendentes & Curiaú - Brasil & 45 & 2 & 6 & 6 & 7 & 0 & 24 & 51,03 & $00,03 \mathrm{~N}$ & Afro-descend. & & 69 \\
\hline S178 & Afro-descendentes & Marajó - Brasil & 35 & 5 & 2 & 0 & 7 & 0 & 21 & 49,45 & $00,50 \mathrm{~S}$ & Afro-descend. & & 19 \\
\hline S179 & Afro-descendentes & $\begin{array}{l}\text { Pacoval e Trombetas - } \\
\text { Brasil }\end{array}$ & 131 & 18 & 12 & 7 & 26 & 0 & 68 & 48,08 & $01,10 \mathrm{~S}$ & Afro-descend. & & 18 \\
\hline S180 & Afro-descendentes & Paredão - Brasil & 7 & 0 & 0 & 1 & 0 & 0 & 6 & & & & & 11 \\
\hline S181 & Afro-descendentes & Pitimandeua - Brasil & 32 & 2 & 4 & 2 & 1 & 0 & 23 & 47,55 & $01,16 \mathrm{~S}$ & Afro-descend. & & 21 \\
\hline S182 & Afro-descendentes & Pontal - Brasil & 34 & 3 & 1 & 3 & 1 & 0 & 26 & 44,47 & $02,26 \mathrm{~S}$ & Afro-descend. & & 19 \\
\hline S183 & Afro-descendentes & Porto Alegre - Brasil & 16 & 0 & 1 & 1 & 0 & 0 & 14 & & & & & 11 \\
\hline S184 & Afro-descendentes & Ribeirão Preto - Brasil & 50 & 0 & 3 & 6 & 0 & 0 & 41 & 47,48 & $21,09 \mathrm{~S}$ & Afro-descend. & & 2 \\
\hline S185 & Afro-descendentes & Salvador - Brasil & 2 & 0 & 0 & 1 & 0 & 0 & 1 & & & & & 11 \\
\hline S186 & Afro-descendentes & Tamauari - Brasil & 34 & 6 & 2 & 3 & 2 & 0 & 21 & 44,15 & $03,00 \mathrm{~S}$ & Afro-descend. & & 20 \\
\hline S187 & Afro-descendentes & Cauca - Colômbia & 20 & 0 & 2 & 0 & 0 & 0 & 18 & & & & & 72 \\
\hline S188 & Afro-descendentes & $\begin{array}{l}\text { Ilha Providência - } \\
\text { Colômbia }\end{array}$ & 40 & 4 & 0 & 0 & 0 & 0 & 36 & & & & & 72 \\
\hline S189 & Afro-descendentes & Nuquí - Colômbia & 33 & 5 & 2 & 0 & 0 & 0 & 26 & 77,00 & $05,05 \mathrm{~N}$ & Afro-descend. & & 72 \\
\hline S190 & Afro-descendentes & $\begin{array}{l}\text { Palenque de San Basilio - } \\
\text { Colômbia }\end{array}$ & 38 & 2 & 2 & 0 & 1 & 0 & 33 & 75,00 & $09,15 \mathrm{~N}$ & Afro-descend. & & 72 \\
\hline S191 & Afro-descendentes & Quibdó - Colômbia & 28 & 2 & 9 & 1 & 0 & 0 & 16 & 76,39 & $05,42 \mathrm{~N}$ & Afro-descend. & & 72 \\
\hline S192 & Afro-descendentes & Melo - Uruguai & 41 & 4 & 5 & 4 & 0 & 0 & 28 & 54,10 & $32,21 \mathrm{~S}$ & Afro-descend. & & 12 \\
\hline S193 & Nipo-descendentes & Ribeirão Preto - Brasil & 40 & 5 & 1 & 0 & 24 & 0 & 10 & & & & & 2 \\
\hline S194 & Nipo-descendentes & Tomé-Açú - Brasil & 40 & 2 & 5 & 2 & 23 & 0 & 8 & & & & & 48 \\
\hline
\end{tabular}

As letras N e S indicam as populações da América do Norte e do Sul, respectivamente. Populações da América Central estão distribuídas entre estes dois grupos.

${ }^{2} n=$ número de indivíduos analisados.

${ }^{3}$ ? = haplogrupos de mtDNA não pertencentes aos cinco característicos dos nativo-americanos. Haplogrupos X de algumas populações da América do Norte, nas quais marcadores que identificam o haplogrupo X não foram analisados, podem estar incluídos nesta categoria. 


\section{${ }^{4}$ Longitude Oeste.}

${ }^{5}$ Afiliação lingüística: Determinada de acordo com a classificação de Greenberg (1987), em três níveis hierárquicos: Família,Estoque,Sub-grupo lingüístico. Famílias: Am Amerind; EA - Eskimo-Aleut; ND - Na-Dene. Estoques: Al - Aleut; An - Andean; CA - Central Amerind; Co - Continental; CP - Chibchan-Paezan; Es - Eskimo; ET Equatorial-Tucanoan; GPC - Ge-Pano-Carib; Ha - Haida; NA - Northern-Amerind. Sub-grupos lingüísticos: AE - Athabaskan-Eyak; Al - Aleut; AK - Almosan-Keresiouan; Ay - Aymara; Ch - Chibchan; Eq - Equatorial; Ha - Haida; Ho - Hokan; In - Inuit; MC - Macro-Carib; MG - Macro-Ge; MP - Macro-Panoan; MT - Macro-Tucanoan; OM Oto-Manguean; Pa - Paezan; Pe - Penutian; Qu - Quechua; So - Southern; Ta - Tanoan; UA - Uto-Aztecan; Yu - Yupik. Cinco populações não tiveram seus sub-grupos lingüísticos determinados.

${ }^{6}$ Área geográfica: As áreas geográficas (Continentes,Regiões intra-continentais) foram delimitadas adaptando-se sugestões da literatura (Lorenz and Smith 1996; Demarchi et al. 2001). Continentes: AmC - América Central; AmN - América do Norte; AmS - América do Sul. Regiões geográficas intra-continentais: Ama - Amazônia; And Cordilheira dos Andes; Art - Ártico/Sub-ártico; Car - Ilhas do Caribe; GrC - Grande Chaco; L/GP - Leste/Grande Planície; Noe - Costa noroeste da América do Norte; Not Norte da América Central; S/GB - Sudoeste/Grande Bacía; Sul - Sul da América Central; TdF - Terra do Fogo.

${ }^{7}$ Referências: 1 (Presente Estudo); 2 (Abé-Sandes 2002); 3 (Alves-Silva et al. 2000); 4 (Bailliet et al. 1994); 5 (Batista et al. 1995); 6 (Batista dos Santos et al. 1999); 7 (Bert et al. 2001); 8 (Bianchi et al. 1995); 9 (Boles et al. 1995); 10 (Bolnick and Smith 2003); 11 (Bortolini et al. 1999); 12 (Bravi et al. 1997); 13 (Brown et al. 1998); 14 (Budowle et al. 2002); 15 (Carlyle et al. 2000); 16 (Carvajal-Carmona et al. 2000); 17 (Carvajal-Carmona et al. 2003); 18 (Carvalho et al. 2001 ); 19 (Carvalho et al. 2002); 20 (Carvalho and Ribeiro-dos-Santos 2003); 21 (Carvalho et al. 2004); 22 (Castro-de-Guerra et al. 2003); 23 (Demarchi et al. 2001 ); 24 (Derbeneva et al. 2002 ); 25 (Dipierri et al. 1998); 26 (Easton et al. 1996); 27 (Eshleman et al. 2004); 28 (Feio-dos-Santos et al. 2001); 29 (Fuselli et al. 2003 ); 30 (García et al. 2004 ); 31 (Ginther et al. 1993); 32 (Goicoechea et al. 2000); 33 (Goicoechea et al. 2001); 34 (Gonzalez-Oliver et al. 2001); 35 (Green et al. 2000); 36 (Henríquez et al. 2004 ); 37 (Horai et al. 1993); 38 (Huoponen et al. 1997); 39 (Kaestle and Smith 2001); 40 (Keyeux et al. 2002); 41 (Kolman et al. 1995); 42 (Kolman and Bermingham 1997); 43 (Lalueza-Fox 1996); 44 (Lalueza-Fox et al. 2001); 45 (Lalueza-Fox et al. 2003); 46 (Lewis et al. 2004); 47 (Lorenz and Smith 1996); 48 (Maciel-Braga et al. 2004 ); 49 (Malhi et al. 2001); 50 (Malhi et al. 2003); 51 (Malhi et al. 2004); 52 (Marrero et al. 2004); 53 (Martinez-Cruzado et al. 2001); 54 (Merriwether et al. 1995); 55 (Merriwether and Ferrell 1996); 56 (Merriwether et al. 1996); 57 (Merriwether et al. 1997a); 58 (Merriwether et al. 1997b); 59 (Mesa et al. 2000); 60 (Monsalve et al. 1994 ); 61 (Monsalve et al. 1996); 62 (Monsalve and Hagelberg 1997); 63 (Moraga et al. 2000); 64 (Moraga et al. 2001); 65 (Moraga et al. 2004); 66 (O'Rourke et al. 2000 ); 67 (Parr et al. 1996); 68 (Ribeiro-dos-Santos et al. 1996); 69 (Ribeiro-dos-Santos et al. 2002); 70 (Rickards et al. 1999); 71 (Rocco et al. 2002); 72 (Rodas et al. 2003); 73 (Rodriguez-Delfin et al. 2001); 74 (Rothhammer et al. 2003); 75 (Rubicz et al. 2003); 76 (Saillard et al. 2000); 77 (Santos et al. 1994); 78 (Santos 1996); 79 (Schmitt et al. 2004 ); 80 (Schurr et al. 1990); 81 (Scozzari et al. 1997); 82 (Shields et al. 1993); 83 (Smith et al. 1999); 84 (Starikovskaya et al. 1998); 85 (Stone and Stoneking 1998); 86 (Toro-Labrador et al. 2003 ); 87 (Torroni et al. 1992 ); 88 (Torroni et al. 1993); 89 (Torroni et al. 1994a); 90 (Torroni et al. 1994b); 91 (Vona et al. 2004); 92 (Ward et al. 1991); 93 (Ward et al. 1993 ); 94 (Ward et al. 1996); 95 (Williams et al. 2002); 96 (Bailliet et al. 2001); 97 (Lalueza-Fox et al. 1997); 98 (Vieira et al. 2002). 


\section{Apêndice B}

Manuscrito derivado de parte dos dados da tese, com objetivo de cumprir as normas da Pósgraduação da Faculdade de Medicina de Ribeirão Preto - USP

\section{VARIABILIDADE DO mtDNA ENTRE ALDEIAS DA TRIBO TIKÚNA REVELA PADRÃO DE HETEROGENEIDADE INFRA-TRIBAL}

Celso Teixeira Mendes-Junior e Aguinaldo Luiz Simões ( $\square)$

Departamento de Genética, Faculdade de Medicina de Ribeirão Preto, Universidade de São Paulo, Av. Bandeirantes 3.900, 14049-900 Ribeirão Preto, SP, Brazil

$(\bowtie)$ Corresponding author. Tel.: +55-16-6023050; fax: +55-16-6023050.

E-mail address: alsimoes@fmrp.usp.br (A.L. Simões) 


\section{RESUMO}

Com o objetivo de estudar a estrutura populacional dos Tikúna, polimorfismos que definem os haplogrupos fundadores do DNA mitocondrial nativo-americano foram analisados em 187 indígenas pertencentes a oito aldeias de tal tribo. A posição central ocupada por estas aldeias no continente sul-americano faz com que sejam relevantes nas tentativas de reconstrução dos movimentos populacionais sul-americanos. Nesta região, existe particular interesse pela estrutura genética da tribo Tikúna, inicialmente tida como enigmática por se preservar como uma das únicas grandes tribos pouco miscigenadas da Amazônia central. Apesar do grande tamanho populacional e da ampla distribuição geográfica, a tribo Tikúna se apresenta isolada lingüística e geneticamente, o que caracteriza ausência de mistura inter-tribal significativa. Marcadores que definem os quatro haplogrupos de mtDNA característicos de populações indígenas de todo o continente foram estudados. Todos os indivíduos apresentaram haplogrupos de origem indígena, o que se traduz em estimativas de mistura inter-étnica feminina praticamente desprezíveis. Existe heterogeneidade intra-tribal nos Tikúna, sendo observados dois grupos altamente homogêneos (um deles formado por Belém e Vendaval e o outro formado pelas seis outras aldeias) que diferem consideravelmente entre si. Aparentemente a diferenciação entre Belém e Vendaval estaria ocorrendo de maneira muito mais intensa entre as linhagens femininas e, embora a tendência à exogamia seja reduzida nestas duas aldeias, o fluxo gênico mediado por homens estaria ocorrendo em intensidade suficiente para homogeneizar o restante do material genético.

Palavras-chave: DNA mitocondrial. Índios sul-americanos. Genética populacional. 


\section{INTRODUÇÃO}

A região centro-oeste da Amazônia brasileira atrai atenção devido à posição central que ocupa no continente sul-americano, o que faz com que seja de grande importância nas tentativas de reconstrução dos movimentos e das relações biológicas entre as populações da América do Sul (Mohrenweiser et al. 1979). Nesta região, existe particular interesse pela origem e estrutura genética da tribo Tikúna, inicialmente tida como enigmática por se preservar como uma das únicas grandes tribos relativamente puras da Amazônia central (Neel et al. 1980). Tal região é de ocupação mais recente, visto que inicialmente os Tikúna ocuparam a base da Cordilheira dos Andes entre a Colômbia e o Peru (Salzano et al. 1980).

Apesar do grande tamanho populacional e da ampla distribuição geográfica, a tribo Tikúna se apresenta isolada lingüística e geneticamente (Neel et al. 1980; Salzano et al. 1980). Trabalhos recém desenvolvidos (Oliveira 1999; Mendes-Junior 2001; Wanderley-Santos 2001; Luizon 2003) têm confirmado sistematicamente este isolamento tribal dos Tikúna relatado há mais de duas décadas. Povos de língua Arawak por muito tempo atuaram como barreira física evitando o acesso dos Tikúna a dois grandes rios (Putumayo-Iça e Solimões), o que dificultou o contato dos Tikúna com não-indígenas.

Marcadores de herança matrilinear (mtDNA) ainda não foram profundamente estudados entre os Tikúna. Embora não sejam poucas as populações sul-americanas em que marcadores de mtDNA tenham sido analisados (Salzano 2002), existe clara necessidade de ampliação de dados relativos a haplogrupos de DNA mitocondrial na região centro-oeste da Amazônia brasileira. Além disso, a região a ser estudada é carente em sítios arqueológicos (Salzano and Callegari-Jacques 1988; Fiedel 2000), o que torna a análise genética de populações contemporâneas isoladas a forma mais adequada (e talvez única) de se obter inferências confiáveis sobre as rotas migratórias nesta região. 
O objetivo deste estudo consiste em levantar freqüências alélicas de conjuntos de marcadores ligados ao DNA mitocondrial em 187 indivíduos distribuídos entre oito aldeias da tribo Tikúna, o que permitirá analisar a estrutura genética feminina desta tribo e quantificar a contribuição feminina européia e africana para o pool gênico das populações indígenas da região centro-oeste da Amazônia brasileira. Consiste em objetivo secundário a comparação entre os dados de mtDNA e de microssatélites do cromossomo $\mathrm{Y}$ (os quais trazem informações complementares, a respeito da história populacional masculina recente) previamente obtidos em quatro destas aldeias (Wanderley-Santos 2001).

Ao contrário do esperado diante da organização social patrilocal e da prática de exogamia intra-tribal características dos Tikúna, isto é, a homogeneidade das aldeias desta tribo (as mulheres tenderiam a deixar sua aldeia natal para se juntarem aos seus maridos de outras aldeias, resultando-se assim na homogeneização do material genético feminino), foi observado heterogeneidade caracterizada por dois grupos altamente homogêneos que diferem consideravelmente entre si. 


\section{MATERIAL E MÉTODOS}

\section{Histórico}

Amostras de sangue de indivíduos pertencentes a oito aldeias da tribos Tikúna foram coletadas no ano de 1976, em expedição à região central da Amazônia Dados sóciodemográficos foram obtidos em cinco destas aldeias (Salzano et al. 1980) e grande quantidade de marcadores clássicos (imunoglobulinas, grupos sangüíneos, proteínas séricas e eritrocitárias) foi analisada em todas estas populações a cerca de 25 anos atrás (Gershowitz and Neel 1978; Mestriner et al. 1980; Neel et al. 1980; Simões 1980). A estrutura populacional de quatro destas aldeias (Belém, Feijoal, Umariaçu e Vendaval), vem sendo intensivamente estudada nos últimos anos, por meio de diferentes marcadores de DNA: inserções Alu (Oliveira 1999) microssatélites autossômicos e ligados ao cromossomo Y (Mendes-Junior 2001; Wanderley-Santos 2001) e PSAs (do inglês, Population Specific Alleles) (Luizon 2003). Estes estudos demonstraram ocorrência de fluxo gênico entre elas que ocasionou forte homogeneidade das aldeias da tribo Tikúna (Oliveira 1999; Mendes-Junior 2001; Wanderley-Santos 2001), o que corrobora informações sócio-demográficas sobre estímulo à prática de exogamia intra-tribal (Salzano et al. 1980).

\section{Amostras populacionais}

Os Tikúna consistem provavelmente no maior grupo de descendentes de uma única tribo que ainda vive no Brasil, habitando o Estado do Amazonas; representantes dos Tikúna também podem ser encontrados em territórios peruano e colombiano. Na época da coleta, só em território brasileiro, havia cerca de 11 mil membros desta tribo (Salzano and Jacques 1979). Censo de 1998 apontou a existência de 32.613 membros desta em território brasileiro (Instituto Socioambiental 2003), o que confirma as indicações de que se encontravam em 
ascensão demográfica (Salzano et al. 1980). Apresenta língua isolada pertencente ao subgrupo lingüístico Macro-Tucanoan, língua esta que não se relaciona claramente a nenhuma outra, mesmo quando pertencentes ao mesmo grupo lingüístico (Neel et al. 1980). Embora apresentem contatos com não-indígenas a cerca de três séculos, esta tribo ainda mantém a sua identidade étnica e casamentos com pessoas de fora são raros; organizam-se socialmente na forma de duas metades exogâmicas patrilineares (Salzano and Jacques 1979). Foram amostradas as aldeias Belém, Bom Jardim, Campo Alegre, Feijoal, Marajá, Nova Itália, Umariaçu e Vendaval, as quais se localizam ao longo do Rio Solimões (Neel et al. 1980; Salzano et al. 1980)

\section{Aspectos Éticos}

O projeto de pesquisa do presente trabalho foi aprovado em seus aspectos éticos pela Comissão de Ética em Pesquisa da Instituição (Hospital das Clínicas - FMRP, USP) de acordo com o processo HCRP n ${ }^{\circ}$ 7869/2004, e também pela Comissão Nacional de Ética em Pesquisa (CONEP) segundo processo $\mathrm{n}^{\mathrm{o}}$ 25000.120707/2004-02. A "Expedição Alpha Helix" foi aprovada segundo processo FUNAI/BSB/4854/75 e autorizações 26/76, 27/76, 74/76 e 75/76 e o banco de amostras reconhecido de acordo com processo HCRP n ${ }^{\circ}$ 9367/2003.

\section{Análise laboratorial}

A extração de DNA de 187 amostras de sangue foi feita a partir de uma adaptação de método proposto (Higuchi 1989), utilizando-se fração de hemácias glicerolizadas, visto que uma pequena quantidade de leucócitos permanece misturada nesta fração. Foram estudados quatro marcadores que definem os haplogrupos ameríndios A (+663 HaeIII), B (Deleção 9pb), C (-13259 HincII) e D (-1571 AluI). Os primers utilizados estão descritos na Tabela 1. 
Os marcadores foram amplificados por PCR e após este procedimento, o produto da reação dos marcadores que definem os haplogrupos A, C e D foram submetidos a reação de clivagem utilizando-se enzimas de restrição sítio-específicos (Tabela 1), de acordo com condições descritas na literatura (Stone and Stoneking 1993; Keyeux et al. 2002). Os produtos de PCR ou PCR-RFLP foram analisados por PAGE 8\% não-desnaturante, com coloração por Nitrato de Prata (Sanguinetti et al. 1994).

\section{Análise estatística}

A freqüência de cada haplogrupo de mtDNA encontrado foi estimada pelo método de contagem direta. A diversidade genética intra-populacional $\left(h_{S k}\right)$ e sua variância amostral (Nei 1987) foram estimadas em cada aldeia utilizando-se o programa Arlequin versão 2.000 (Schneider et al. 2000). O mesmo programa foi empregado nos cálculos de $F_{S T}$ entre duas ou mais populações (Weir and Cockerham 1984), Análise de Variância Molecular (AMOVA) (Excoffier et al. 1992) e teste exato de diferenciação populacional.

Visto que em sua forma convencional a análise de $F_{S T}$ tem por pressuposto oculto que a identidade gênica esperada e o tamanho efetivo populacional são iguais em todas as subpopulações consideradas, a violação de tais pressupostos, o que é de ocorrência constante na natureza, pode trazer viés às estimativas (Long and Kittles 2003). Portanto, valores de $F_{S T}$ população-específicos $\left(F_{S T(k)}\right)$ também foram estimados (Long and Kittles 2003).

As distâncias geográficas entre os 28 pares formados pelas 8 aldeias Tikúna estudadas foram calculadas a partir das coordenadas geográficas (latitude e longitude) por meio do aplicativo Calculator for Distances between Geographical Locations (Bogan 1998). Coeficiente de correlação para postos de Spearman $\left(r_{S}\right)$ entre distâncias genéticas e tais distâncias geográfica foi estimado utilizando-se o programa BioEstat 2.0 (Ayres et al. 2000). 


\section{RESULTADOS}

\section{Diversidade Intra-populacional}

Os quatro haplogrupos de DNA mitocondrial característico de populações indígenas sul-americanas autóctones foram encontrados na presente amostra (Tabela 2). Todos os indivíduos apresentaram um destes quatro haplogrupos, não havendo, portanto, a possibilidade de se encontrar haplogrupo de origem européia ou africana. Cada aldeia apresentou três ou quatro haplogrupos, sendo que o haplogrupo B foi o menos freqüente e se restringiu a apenas cinco aldeias. A diversidade intra-populacional variou de 0,5692 na aldeia Belém até 0,7662 na aldeia Marajá (Tabela 2).

\section{Diversidade Inter-populacional}

Dois métodos distintos que possuem a mesma finalidade de quantificar o grau de diferenciação entre pares ou conjuntos de populações associados à significância estatística, isto é, a probabilidade de se obter pares ou conjuntos de amostras mais heterogêneos do que aquele em questão, foram empregados: $F_{S T}$ e teste exato de diferenciação populacional. Embora as informações destas análises sejam de certa forma redundantes, a intenção foi justamente de proporcionar conclusões mais robustas possíveis, uma vez que um método de análise pode ser mais sensível ou conservativo do que outros.

O teste exato de diferenciação populacional baseado nas freqüências de haplogrupos $(p=0,0059)$ e a análise de $F_{S T}\left(F_{S T}=0,0481 ; p=0,0058\right)$ mostraram que existe diversidade altamente significante entre as oito aldeias Tikúna. Analisando-se a matriz de $F_{S T}$ entre pares de aldeias, observa-se grande amplitude de variação nos valores de $F_{S T}$ : $-0,0393$ a 0,2258 (Tabela 3). Verifica-se que $6(21,43 \%)$ dos 28 pares de aldeia Tikúna diferem significantemente ao nível de 5\% (Tabela 4). A mesma tendência é observada na matriz com valores de probabilidade de não-diferenciação a partir de teste exato (Tabela 4). Não foi 
observada correlação significante entre as distâncias genéticas $\left(F_{S T}\right)$ e geográficas (presentes na Tabela 3) entre os 28 pares de aldeias Tikúna $\left(r_{S}=-0,2589 ; p=0,1833\right)$.

Diante deste achado de heterogeneidade significante entre as aldeias Tikúna, torna-se necessário identificar se as aldeias Tikúna são igualmente diferentes umas das outras, ou se dentro do grupo existem um conjunto de aldeias homogêneas juntamente com uma ou duas que constituem verdadeiras exceções. Para identificar estas possíveis aldeias destoantes (outliers), foi empregado o cálculo de $F_{S T}$ população-específicos (Tabela 5).

Os valores de $F_{S T(k)}$ variaram de -0,0534 (Marajá) até 0,2117 (Belém). Além de Belém, a aldeia Vendaval $\left(F_{S T(k)}=0,1560\right)$ se mostrou bem mais divergente do que as demais (Tabela 5). Ao se estimar $F_{S T}$ novamente, excluindo-se a aldeia Belém, obtém-se valor significante apenas ao nível de $5 \%\left(F_{S T}=0,0322 ; p=0,0397\right)$. Se além da aldeia Belém for excluída também a aldeia Vendaval, obtém-se $F_{S T}$ bastante reduzido e não-significante $\left(F_{S T}=0,0156 ; p\right.$ $=0,1754$ ). Ao observar as freqüências dos haplogrupos nestas duas aldeias (Tabela 2), observa-se que elas apresentam perfil genético quase idêntico: haplogrupo D em freqüências muito elevadas, haplogrupo $\mathrm{C}$ em freqüências menores do que nas demais aldeias e ausência do haplogrupo B. Tanto $F_{S T}$ quanto teste exato de diferenciação populacional baseados em pares de aldeias (Tabelas 3 e 5) indicam forte homogeneidade entre as aldeias Belém e Vendaval $(p=1,0000)$.

\section{Análise de Variância Molecular}

Assumindo-se estrutura hierárquica com a tribo Tikúna fragmentada, sendo que as aldeias que apresentaram elevados valores de $F_{S T(\mathrm{k})}$ (Belém e Vendaval) passaram a formar grupo à parte, foi observado que $8,62 \%$ da variância é decorrente às diferenças entre grupos, enquanto que apenas $0,76 \%$ da mesma resulta de diferenças entre aldeias de mesmo grupo. 


\section{DISCUSSÃO}

\section{Mistura inter-étnica}

Nenhum dos 187 indivíduos estudados apresentou haplogrupo de origem não-indígena (Tabela 2). Em estudo de marcadores clássicos no mesmo conjunto de populações aqui estudadas verificou-se níveis de mistura variando de $1,1 \%$ (pela análise de imunoglobulinas) a 3,3\% (pela análise do grupo sangüíneo ABO) (Neel et al. 1980; Salzano and CallegariJacques 1988).

Já a inserção Alu YAP, ausente em populações indígenas pré-colombianas cuja presença é atribuída de imediato à mistura inter-étnica (Bianchi et al. 1997; Karafet et al. 1997), foi encontrada em 2 indivíduos (em dois haplótipos bastante divergentes) dentre 100 analisados das aldeias Belém, Feijoal, Umariaçu e Vendaval, o que sugere a ocorrência de mistura mediada por homens nesta tribo de pelo menos 2,0\% (Wanderley-Santos et al. 2005). Enquanto que na África a freqüência desta inserção chega a alcançar 100\% em algumas populações, na Europa Oriental as freqüências não chegam a atingir 30\% (Quintana-Murci et al. 1999; Bravi et al. 2000; Forster et al. 2000; Malaspina et al. 2000). Visto que dados históricos e genéticos revelam que desde o início da colonização do Brasil o padrão de mistura inter-étnica relativamente comum envolvia relações entre homens portugueses e mulheres indígenas (e africanas) (Alves-Silva et al. 2000; Carvalho-Silva et al. 2001), o mais provável é que estes dois haplótipos $\mathrm{YAP}^{+}$sejam de origem européia. Sendo assim, haplótipos de origem européia que não portam a inserção Alu YAP também devem estar presentes na amostra, convertendo a estimativa de mistura inter-étnica masculina mencionada $(2,0 \%)$ em clara sub-estimativa. Portanto os pequenos níveis de mistura inter-étnica observados nas aldeias aqui estudadas indicam que elas estão entre as que conseguiram preservar um pouco 
mais de sua identidade genética devido ao difícil acesso à Floresta Amazônica. A mistura feminina é desprezível, enquanto que a mistura masculina é pouco mais significativa e provavelmente, embasado em dados históricos e genéticos (Carvajal-Carmona et al. 2000; Mesa et al. 2000; Bortolini et al. 2002), mediada por homens europeus.

Baseado nos dados de mtDNA aqui obtidos, inferências quanto à significância deste resultado podem ser realizadas: a partir da equação binomial, pode-se estimar que a probabilidade deste achado, isto é, de não se encontrar haplogrupo não-indígena em amostra composta por 187 indivíduos, é inferior a 1\% quando se assume nível de mistura maior do que $2,5 \%$ na população da qual a amostra se originou e inferior a $5 \%$ quando se assume mistura maior do que $1,6 \%$. Portanto, ao nível de significância de 0,05 , a presente amostra permite descartar ocorrência de mistura superior a 1,6\% na tribo da qual as amostras se originaram.

\section{Diversidade Intra-tribal dos Tikúna}

Foi identificada heterogeneidade significante entre as aldeias desta tribo $\left(F_{S T}=\right.$ 0,0481). Dois aspectos precisam ser considerados a este respeito. Primeiro, um resultado estatisticamente significante não representa automaticamente significância biológica (Callegari-Jacques 2003). Enquanto que a significância estatística serve para medir o grau de confiança de que uma diferença obtida seja espúria, sendo altamente dependente do tamanho amostral e da magnitude da diferença, ela de modo algum indica se a diferença é pequena, moderada ou grande (Callegari-Jacques 2003). Neste caso, observa-se que a diferença entre as aldeias Tikúna é significante (confiável), porém menor do que entre aldeias de outras tribos descritas na literatura.

Segundo, analisando detalhadamente as aldeias Tikúna através da estimativa de $F_{S T}$ população-específicos $\left(F_{S T(k)}\right)$, foi possível identificar a presença de duas aldeias (Belém e 
Vendaval) altamente divergentes das demais (Tabela 5), porém geneticamente quase idênticas entre si (Tabelas 3 e 4). A exclusão destas duas aldeias conduz a $F_{S T}$ não-significante e de magnitude $67,57 \%$ menor do que o valor supra-citado $\left(F_{S T}=0,0156 ; p=0,1754\right)$. Dentre as seis diferenças significantes entre pares de aldeias Tikúna (Tabelas 3 e 4), a maioria inclui a aldeia Belém ou Vendaval. Excluindo tais aldeias, tem-se que das 15 comparações entre os seis pares de aldeias restantes apenas $2(13,33 \%)$, pela análise de $F_{S T}$, e $1(6,67 \%)$, pelo teste exato, se apresentaram significantes ao nível de 5\%. Aplicando-se a correção de Bonferroni para múltiplas comparações, nenhuma delas permanece significante ao nível mencionado. Portanto, conclui-se que pelo menos as seis aldeias restantes são realmente homogêneas enquanto que as aldeias Belém e Vendaval formam um grupo homogêneo à parte. Este padrão é ainda corroborado pela representação bi-dimensional da matriz de distâncias genéticas de Reynolds (dados não apresentados), na qual Belém e Vendaval se inserem em posições distantes das demais aldeias Tikúna.

É possível que este cenário esteja retratando o início de um processo de diferenciação destas duas aldeias em relação às demais. Alguns dados demográficos (Salzano et al. 1980), embora disponíveis apenas com relação a cinco das oito aldeias aqui estudadas, permitem visualizar a dicotomia entre Belém e Vendaval em relação às demais. Enquanto que em Belém (73\%) e Vendaval (76\%) a maior parte dos casamentos envolvem dois membros da mesma tribo, Nova Itália, Umariaçu e Campo Alegre apresentam apenas de 5\% a 16\% de seus casamentos organizados desta forma. Os adultos das duas primeiras nasceram em média entre 7 e 12 quilômetros da aldeia em que residem, sendo que 84\%-88\% deles nasceram na mesma; por outro lado, os adultos das três últimas nasceram em média entre 32 e 147 quilômetros da aldeia em que vivem, sendo que apenas 15\%-39\% deles nasceram na mesma (Salzano et al. 1980). Em resumo, Belém e Vendaval apresentam menor tendência à exogamia do que as demais aldeias, embora esta característica ainda esteja presente. 
Este processo de diferenciação, no entanto, não é observável pela re-análise de marcadores clássicos $\left(F_{S T}=0,003 ; p>0,05\right)$ (Mendes-Junior 2001), pela análise de inserções $\operatorname{Alu}\left(F_{S T}=0,006 ; p>0,05\right)($ Oliveira 1999$)$ e microssatélites autossômicos $\left(F_{S T}=0,0073 ; p\right.$ $<0,01$ ) (Mendes-Junior 2001), pelos quais foi constatada forte homogeneidade no conjunto formado entre as quatro aldeias Tikúna estudadas (Belém, Vendaval, Feijoal e Umariaçu). Microssatélites ligados ao cromossomo Y $\left(F_{S T}=0,0272 ; p>0,05\right)$ (Wanderley-Santos et al. 2005), marcadores que refletem a história populacional masculina e PSAs $\left(F_{S T}=0,026 ; \mathrm{p}<\right.$ 0,01) (Luizon 2003), marcadores que tiveram a informatividade quanto à aplicabilidade em estudos micro-evolutivos questionada, também não corroboram tal diferenciação de Belém e Vendaval.

Deste modo, a única explicação plausível é de que tal diferenciação por deriva genética esteja ocorrendo de maneira muito mais intensa entre as linhagens femininas e, embora a tendência à exogamia seja reduzida nestas duas aldeias, o fluxo gênico mediado por homens esteja ocorrendo em intensidade suficiente para homogeneizar até mesmo o material genético autossômico, que já é por natureza menos afetado pelos efeitos da deriva do que o mtDNA e o cromossomo Y. No entanto, diante dos indícios de que se trata de tribo com clãs exogâmicos patrilineares (Salzano et al. 1980; Simões 1980), que por sua vez acaba resultando em patrilocalidade, seria esperado que os homens migrassem menos do que as mulheres. Portanto, os dados genéticos parecem ser, a princípio, incompatíveis com os dados sócio-demográficos. Não se pode, contudo, descartar a hipótese de que o padrão de organização social supracitado tenha sido desfigurado pela explosão demográfica dos Tikúna que vinha ocorrendo desde as décadas anteriores à coleta (1976), aliada ao movimento religioso denominado "Holy Cross", iniciado em 1972 nesta região e que transformou algumas aldeias situadas ao longo do Rio Solimões em verdadeiros pólos de atração para os quais muitas famílias se direcionaram (Salzano et al. 1980). Tal movimento alterou 
dramaticamente o tamanho e a composição de muitas aldeias Tikúna (Salzano et al. 1980), o que pode estar se refletindo de maneira significativa nos dados genéticos apresentados.

Estes achados aliados à ausência de correlação entre distâncias genéticas $\left(F_{S T}\right)$ e geográficas $\left(r_{S}=-0,2589 ; p=0,1833\right)$ sugere que a organização social, representada na forma de uniões exogâmicas envolvendo membros de clãs e aldeias distintos (talvez até mesmo buscando a união entre indivíduos de aldeias mais distanciadas), e não a geografia, seria provável fator influenciando a diversidade genética das aldeias de tal tribo. 


\section{AGRADECIMENTOS}

Este trabalho contou com auxílio financeiro da Coordenação de Aperfeiçoamento de Pessoal de Nível Superior (CAPES), Conselho Nacional de Desenvolvimento Científico e Tecnológico (CNPq), Fundação de Amparo à Pesquisa do Estado de São Paulo (FAPESP) e Fundação de Apoio ao Ensino, Pesquisa e Assistência do HCFMRP-USP (FAEPA). 


\section{REFERÊNCIAS BIBLIOGRÁFICAS}

Alves-Silva J, da Silva Santos M, Guimaraes PE, Ferreira AC, Bandelt HJ, Pena SD, Prado VF (2000) The ancestry of Brazilian mtDNA lineages. Am J Hum Genet 67:444-61

Ayres M, Ayres Jr M, Ayres DL, Santos AAS (2000) BioEstat 2.0: aplicações estatísticas nas áreas das ciências biológicas e médicas

Bianchi NO, Bailliet G, Bravi CM, Carnese RF, Rothhammer F, Martinez-Marignac VL, Pena SD (1997) Origin of Amerindian Y-chromosomes as inferred by the analysis of six polymorphic markers. Am J Phys Anthropol 102:79-89

Bogan L (1998) Calculator for distances between geographical locations. Disponível em: $<$ http://www.go.ednet.ns.ca/ larry/bsc/jslatlng.html>. Acesso em: 11 abr. 2005

Bortolini MC, Salzano FM, Bau CH, Layrisse Z, Petzl-Erler ML, Tsuneto LT, Hill K, Hurtado AM, Castro-De-Guerra D, Bedoya G, Ruiz-Linares A (2002) Y-chromosome biallelic polymorphisms and Native American population structure. Ann Hum Genet $66: 255-9$

Bravi CM, Bailliet G, Martinez-Marignac VL, Bianchi NO (2000) Origin of YAP+ lineages of the human Y-chromosome. Am J Phys Anthropol 112:149-58

Callegari-Jacques SM (2003) Bioestatística: princípios e aplicações. Artmed, Porto Alegre

Carvajal-Carmona LG, Soto ID, Pineda N, Ortiz-Barrientos D, Duque C, Ospina-Duque J, McCarthy M, Montoya P, Alvarez VM, Bedoya G, Ruiz-Linares A (2000) Strong Amerind/white sex bias and a possible Sephardic contribution among the founders of a population in northwest Colombia. Am J Hum Genet 67:1287-95

Carvalho-Silva DR, Santos FR, Rocha J, Pena SD (2001) The phylogeography of Brazilian Ychromosome lineages. Am J Hum Genet 68:281-6

Excoffier L, Smouse PE, Quattro JM (1992) Analysis of molecular variance inferred from metric distances among DNA haplotypes: application to human mitochondrial DNA restriction data. Genetics 131:479-91

Fiedel SJ (2000) The peopling of the New World: present evidence, new theories, and future directions. J Archaeol Res 8:39-103

Forster P, Rohl A, Lunnemann P, Brinkmann C, Zerjal T, Tyler-Smith C, Brinkmann B (2000) A short tandem repeat-based phylogeny for the human Y chromosome. Am J Hum Genet 67:182-96

Gershowitz H, Neel JV (1978) The immunoglobulin allotypes (Gm and Km) of twelve Indian tribes of Central and South America. Am J Phys Anthropol 49:289-301 
Higuchi R (1989) Simple and rapid preparation of samples for PCR. In: Erlich HA (ed) PCR technology: principles an applications for DNA amplification. Stockton Press, New York pp 31-8

Instituto Socioambiental I (2003) Povos indígenas no Brasil. Disponível em: $<$ http://www.socioambiental.org/pib/portugues/quonqua/quadro.asp $>$. Acesso em: $11 \mathrm{abr}$. 2005

Karafet T, Zegura SL, Vuturo-Brady J, Posukh O, Osipova L, Wiebe V, Romero F, Long JC, Harihara S, Jin F, Dashnyam B, Gerelsaikhan T, Omoto K, Hammer MF (1997) Y chromosome markers and Trans-Bering Strait dispersals. Am J Phys Anthropol 102:30114

Keyeux G, Rodas C, Gelvez N, Carter D (2002) Possible migration routes into South America deduced from mitochondrial DNA studies in Colombian Amerindian populations. Hum Biol 74:211-33

Long JC, Kittles RA (2003) Human genetic diversity and the nonexistence of biological races. Hum Biol 75:449-71

Luizon MR (2003) Polimorfismos de DNA população-específicos em indígenas da Amazônia brasileira. Dissertação de Mestrado apresentada à Faculdade de Medicina de Ribeirão Preto, da Universidade de São Paulo

Malaspina P, Cruciani F, Santolamazza P, Torroni A, Pangrazio A, Akar N, Bakalli V, Brdicka R, Jaruzelska J, Kozlov A, Malyarchuk B, Mehdi SQ, Michalodimitrakis E, Varesi L, Memmi MM, Vona G, Villems R, Parik J, Romano V, Stefan M, Stenico M, Terrenato L, Novelletto A, Scozzari R (2000) Patterns of male-specific inter-population divergence in Europe, West Asia and North Africa. Ann Hum Genet 64:395-412

Mendes-Junior CT (2001) Freqüências alélicas de polimorfismos de DNA do tipo STR em indígenas da Amazônia brasileira. Dissertação de Mestrado apresentada à Faculdade de Medicina de Ribeirão Preto, da Universidade de São Paulo

Mesa NR, Mondragon MC, Soto ID, Parra MV, Duque C, Ortiz-Barrientos D, Garcia LF, Velez ID, Bravo ML, Munera JG, Bedoya G, Bortolini MC, Ruiz-Linares A (2000) Autosomal, mtDNA, and Y-chromosome diversity in Amerinds: pre- and post-Columbian patterns of gene flow in South America. Am J Hum Genet 67:1277-86

Mestriner MA, Simoes AL, Salzano FM (1980) New studies on the esterase D polymorphism in South American Indians. Am J Phys Anthropol 52:95-101

Mohrenweiser H, Neel JV, Mestriner MA, Salzano FM, Migliazza E, Simoes AL, Yoshihara CM (1979) Electrophoretic variants in three Amerindian tribes: the Baniwa, Kanamari, and Central Pano of western Brazil. Am J Phys Anthropol 50:237-46

Neel JV, Gershowitz H, Mohrenweiser HW, Amos B, Kostyu DD, Salzano FM, Mestriner MA, Lawrence D, Simoes AL, Smouse PE, Oliver WJ, Spielman RS, Neel JV, Jr. (1980) Genetic studies on the Ticuna, an enigmatic tribe of Central Amazonas. Ann Hum Genet 44:37-54

Nei M (1987) Molecular evolutionary genetics. Columbia University Press, New York 
Oliveira SF (1999) Inserções Alu recentes em indígenas da Amazônia brasileira. Tese Doutorado apresentada à Faculdade de Medicina de Ribeirão Preto, da Universidade de São Paulo

Quintana-Murci L, Semino O, Poloni ES, Liu A, Van Gijn M, Passarino G, Brega A, Nasidze IS, Maccioni L, Cossu G, al-Zahery N, Kidd JR, Kidd KK, Santachiara-Benerecetti AS (1999) Y-chromosome specific YCAII, DYS19 and YAP polymorphisms in human populations: a comparative study. Ann Hum Genet 63:153-66

Salzano FM (2002) Molecular variability in Amerindians: widespread but uneven information. An Acad Bras Cienc 74:223-63

Salzano FM, Callegari-Jacques SM (1988) South american indians: a case study in evolution. Oxford University Press, New York

Salzano FM, Callegari-Jacques SM, Neel JV (1980) Genetic demography of the Amazonian Ticuna indians. J Hum Evol 9:179-91

Salzano FM, Jacques SM (1979) Genetic demography of the Central Pano and Kanamari Indians of Brazil. Hum Biol 51:551-64

Sanguinetti CJ, Dias Neto E, Simpson AJ (1994) Rapid silver staining and recovery of PCR products separated on polyacrylamide gels. Biotechniques 17:914-21

Schneider S, Roessli D, Excoffier L (2000) Arlequin ver. 2000: a software for population genetics data analysis. Genetics and Biometry Laboratory, University of Geneva, Switzerland

Simões AL (1980) O polimorfismo da esterase D em indígenas sul-americanos. Tese Doutorado apresentada à Faculdade de Medicina de Ribeirão Preto, da Universidade de São Paulo

Stone AC, Stoneking M (1993) Ancient DNA from a pre-Columbian Amerindian population. Am J Phys Anthropol 92:463-71

Wanderley-Santos LM (2001) STRs autossômicos e ligados ao cromossomo Y em indígenas brasileiros. Tese de Doutorado apresentada à Faculdade de Medicina de Ribeirão Preto, da Universidade de São Paulo

Wanderley-Santos LM, Sousa SMB, Oliveira SF, Mendes-Junior CT, Leboute APM, Simões AL (2005) Genetic diversity of Y-specific STRs in indigenous populations of the Brazilian Amazon. Hum Biol (Submetido)

Weir B, Cockerham CC (1984) Estimating F-statistics for the analysis of population structure. Evolution 38:1358-70 


\section{TABELAS}

Tabela 1 - Descrição dos primers, temperaturas de pareamento $\left(T_{P}\right)$ utilizadas para a amplificação por PCR e tamanhos dos fragmentos obtidos após a PCR e após a reação de restrição (RFLP).

Tabela 2 - Freqüências absolutas dos haplogrupos de DNA mitocondrial e diversidade genética intra-populacional em cada aldeia Tikúna estudada.

Tabela 3 - Matriz de valores de $F_{S T}$ obtidos a partir das freqüências dos haplogrupos de mtDNA (abaixo da diagonal) e de distâncias geográficas em quilômetros (acima da diagonal) entre as oito aldeias Tikúna analisadas no presente estudo. As letras iniciais dos nomes das aldeias foram utilizadas para identificá-las no cabeçalho. Os valores de $F_{S T}$ significantes aos níveis de 5\% e 1\% estão destacados em itálico e negrito, respectivamente.

Tabela 4 - Matriz de probabilidades relacionadas aos valores de $F_{S T}$ apresentados na Tabela 4 (abaixo da diagonal) e probabilidades de não-diferenciação obtidas em teste exato de diferenciação populacional baseado nas freqüências dos haplogrupos de mtDNA (acima da diagonal) entre as oito aldeias Tikúna analisadas no presente estudo. As letras iniciais dos nomes das aldeias foram utilizadas para identificá-las no cabeçalho. Os valores significantes aos níveis de $5 \%$ e $1 \%$ estão destacados em itálico e negrito, respectivamente.

Tabela 5 - Estimativa de valores de $F_{S T}$ população-específicos $\left(F_{S T(k)}\right)$ nas oito aldeias da tribo Tikúna, tomando como referencial para cada cálculo a identidade gênica da aldeia $\left(J_{k}\right)$ e a identidade gênica total da tribo $\left(J_{T}\right)$. 
Tabela 1 - Descrição dos primers, temperaturas de pareamento $\left(T_{P}\right)$ utilizadas para a amplificação por PCR e tamanhos dos fragmentos obtidos após a PCR e após a reação de restrição (RFLP).

\begin{tabular}{|c|c|c|c|c|c|c|c|}
\hline \multirow[t]{2}{*}{ Hap $^{l}$} & $E R^{2}-$ & Primers & 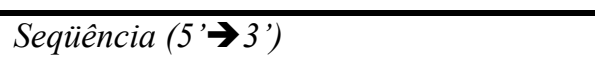 & $T_{P}$ & $P C R$ & $\overline{R F L P}$ & $\overline{\text { Ref. }{ }^{4}}$ \\
\hline & \multicolumn{3}{|l|}{ Marcador } & \multicolumn{4}{|l|}{$\left({ }^{\circ} \mathrm{C}\right)$} \\
\hline \multirow[t]{2}{*}{ A } & HaeIII- & L611 & ACCTCСТCAAAGCAATACACTG & \multirow[t]{2}{*}{52} & \multirow[t]{2}{*}{176} & 101, & \multirow[t]{2}{*}{1,2} \\
\hline & 663 & H743 & GTGCTTGATGCTTGTTCCTTTTG & & & 75 & \\
\hline \multirow[t]{2}{*}{ B } & Del 9pb ${ }^{3}$ & L8215 & ACAGTTTCATGCCCATCGTC & \multirow[t]{2}{*}{50} & $121(-)$ & - & \multirow[t]{2}{*}{1,2} \\
\hline & & H8297 & ATGCTAAGTTAGCTTTACAG & & $112(+)$ & & \\
\hline \multirow[t]{2}{*}{$\mathrm{C}$} & HincII- & L13232 & CGCCCTTACACAAAATGACATCAA & \multirow[t]{2}{*}{50} & \multirow[t]{2}{*}{211} & 158, & \multirow[t]{2}{*}{1,2} \\
\hline & 13259 & H13393 & TCCTATTTTTCGAATATCTTGTTC & & & 53 & \\
\hline \multirow[t]{2}{*}{$\mathrm{D}$} & AluI- & L5120 & TAACTACTACCGCATTCCTA & \multirow[t]{2}{*}{52} & \multirow[t]{2}{*}{149} & 77 , & \multirow[t]{2}{*}{1,2} \\
\hline & 5176 & H5230 & AAAGCCGTTAGCGGGGGCA & & & 72 & \\
\hline
\end{tabular}

\footnotetext{
${ }^{1}$ Hap: Haplogrupo do mtDNA;

${ }^{2}$ ER: Enzima de Restrição para diagnóstico do haplogrupo;

${ }^{3} \mathrm{O}$ diagnóstico do haplogrupo B não requer reação de restrição;

${ }^{4}$ Referências: 1 Stone e Stoneking, 1993; 2 - Keyeux et al., 2002.
} 
Tabela 2 - Freqüências absolutas dos haplogrupos de DNA mitocondrial e diversidade genética intrapopulacional em cada aldeia Tikúna estudada.

\begin{tabular}{|c|c|c|c|c|c|c|}
\hline \multirow{2}{*}{ Aldeia } & \multirow{2}{*}{$n^{l}$} & \multicolumn{4}{|c|}{ Haplogrupos } & \multirow[t]{2}{*}{$h_{S k}$} \\
\hline & & $\bar{A}$ & $B$ & $C$ & $D$ & \\
\hline Belém & 26 & 5 & & 5 & 16 & $0,5692 \pm 0,0838$ \\
\hline Bom Jardim & 18 & 3 & 2 & 10 & 3 & $0,6601 \pm 0,0998$ \\
\hline Campo Alegre & 23 & 5 & 1 & 9 & 8 & $0,7075 \pm 0,0466$ \\
\hline Feijoal & 25 & 12 & 2 & 9 & 2 & $0,6533 \pm 0,0611$ \\
\hline Marajá & 22 & 7 & 3 & 6 & 6 & $0,7662 \pm 0,0374$ \\
\hline Nova Itália & 26 & 5 & 3 & 9 & 9 & $0,7385 \pm 0,0418$ \\
\hline Umariaçu & 24 & 4 & & 11 & 9 & $0,6486 \pm 0,0501$ \\
\hline Vendaval & 23 & 5 & & 5 & 13 & $0,6126 \pm 0,0768$ \\
\hline Tikúna (Total) & 187 & 46 & 11 & 64 & 66 & $0,6981 \pm 0,0116$ \\
\hline
\end{tabular}

$1 \frac{1}{n=\text { número de indivíduos analisados; }}$ 
Tabela 3 - Matriz de valores de $F_{S T}$ obtidos a partir das freqüências dos haplogrupos de mtDNA (abaixo da diagonal) e de distâncias geográficas em quilômetros (acima da diagonal) entre as oito aldeias Tikúna analisadas no presente estudo. As letras iniciais dos nomes das aldeias foram utilizadas para identificá-las no cabeçalho. Os valores de $F_{S T}$ significantes aos níveis de 5\% e $1 \%$ estão destacados em itálico e negrito, respectivamente.

\begin{tabular}{lrrrrrrrr}
\hline & \multicolumn{1}{c}{$B$} & \multicolumn{1}{c}{$B J$} & \multicolumn{1}{c}{$C A$} & \multicolumn{1}{c}{$F$} & \multicolumn{1}{c}{$M$} & \multicolumn{1}{c}{$N I$} & \multicolumn{1}{c}{$U$} \\
\hline Belém & 0 & 73,29 & 58,31 & 37,04 & 46,99 & 169,89 & 52,47 & 49,65 \\
Bom Jardim & $\mathbf{0 , 1 9 2 7}$ & 0 & 129,10 & 54,98 & 39,93 & 232,20 & 20,89 & 121,30 \\
Campo Alegre & 0,0465 & $-0,0008$ & 0 & 93,33 & 105,10 & 149,79 & 108,95 & 9,21 \\
Feijoal & $\mathbf{0 , 2 2 5 8}$ & 0,0590 & 0,0597 & 0 & 15,89 & 177,30 & 37,19 & 84,25 \\
Marajá & 0,0725 & 0,0285 & $-0,0187$ & 0,0097 & 0 & 192,87 & 24,68 & 96,24 \\
Nova Itália & 0,0433 & 0,0072 & $-0,0369$ & 0,0672 & $-0,0245$ & 0 & 213,06 & 148,70 \\
Umariaçu & 0,0622 & 0,0013 & $-0,0367$ & 0,1021 & 0,0175 & $-0,0208$ & 0 & 100,94 \\
Vendaval & $-0,0393$ & 0,1511 & 0,0164 & $\mathbf{0 , 1 8 0 0}$ & 0,0393 & 0,0165 & 0,0330 & 0 \\
\hline
\end{tabular}


Tabela 4 - Matriz de probabilidades relacionadas aos valores de $F_{S T}$ apresentados na Tabela 4 (abaixo da diagonal) e probabilidades de não-diferenciação obtidas em teste exato de diferenciação populacional baseado nas freqüências dos haplogrupos de mtDNA (acima da diagonal) entre as oito aldeias Tikúna analisadas no presente estudo. As letras iniciais dos nomes das aldeias foram utilizadas para identificá-las no cabeçalho. Os valores significantes aos níveis de 5\% e $1 \%$ estão destacados em itálico e negrito, respectivamente.

\begin{tabular}{lcccccccc}
\hline & \multicolumn{1}{c}{$B$} & \multicolumn{1}{c}{$B J$} & \multicolumn{1}{c}{$C A$} & \multicolumn{1}{c}{$F$} & \multicolumn{1}{c}{$M$} & \multicolumn{1}{c}{$N I$} & \multicolumn{1}{c}{$U$} \\
\hline Belém & - & $\mathbf{0 , 0 0 4 7}$ & 0,1769 & $\mathbf{0 , 0 0 0 3}$ & 0,0485 & 0,1135 & 0,1190 & 1,0000 \\
Bom Jardim & $\mathbf{0 , 0 0 3 3}$ & - & 0,4931 & 0,1883 & 0,3461 & 0,4776 & 0,2526 & 0,0170 \\
Campo Alegre & 0,1180 & 0,3732 & - & 0,0711 & 0,5790 & 0,8995 & 0,8920 & 0,3046 \\
Feijoal & $\mathbf{0 , 0 0 0 1}$ & 0,0780 & 0,0770 & - & 0,3109 & 0,0526 & $\mathbf{0 , 0 0 8 3}$ & $\mathbf{0 , 0 0 2 6}$ \\
Marajá & 0,0526 & 0,1987 & 0,6392 & 0,2841 & - & 0,7727 & 0,1386 & 0,1227 \\
Nova Itália & 0,1074 & 0,3205 & 0,9470 & 0,0441 & 0,7013 & - & 0,4630 & 0,2193 \\
Umariaçu & 0,0861 & 0,3205 & 0,8928 & 0,0206 & 0,2607 & 0,6742 & - & 0,2474 \\
Vendaval & 1,0000 & 0,0104 & 0,2794 & $\mathbf{0 , 0 0 1 5}$ & 0,1430 & 0,2200 & 0,1734 & - \\
\hline
\end{tabular}


Tabela 5 - Estimativa de valores de $F_{S T}$ população-específicos $\left(F_{S T(k)}\right)$ nas oito aldeias da tribo Tikúna, tomando como referencial para cada cálculo a identidade gênica da aldeia $\left(J_{k}\right)$ e a identidade gênica total da tribo $\left(J_{T}\right)$.

\begin{tabular}{lccc}
\hline Aldeia & $J_{k}$ & $J_{T}$ & $F_{S T(k)}$ \\
\hline Belém & 0,4527 & 0,3057 & 0,2117 \\
Bom Jardim & 0,3765 & 0,3057 & 0,1021 \\
Campo Alegre & 0,3233 & 0,3057 & 0,0253 \\
Feijoal & 0,3728 & 0,3057 & 0,0967 \\
Marajá & 0,2686 & 0,3057 & $-0,0534$ \\
Nova Itália & 0,2899 & 0,3057 & $-0,0227$ \\
Umariaçu & 0,3785 & 0,3057 & 0,1049 \\
Vendaval & 0,4140 & 0,3057 & 0,1560 \\
\hline
\end{tabular}

